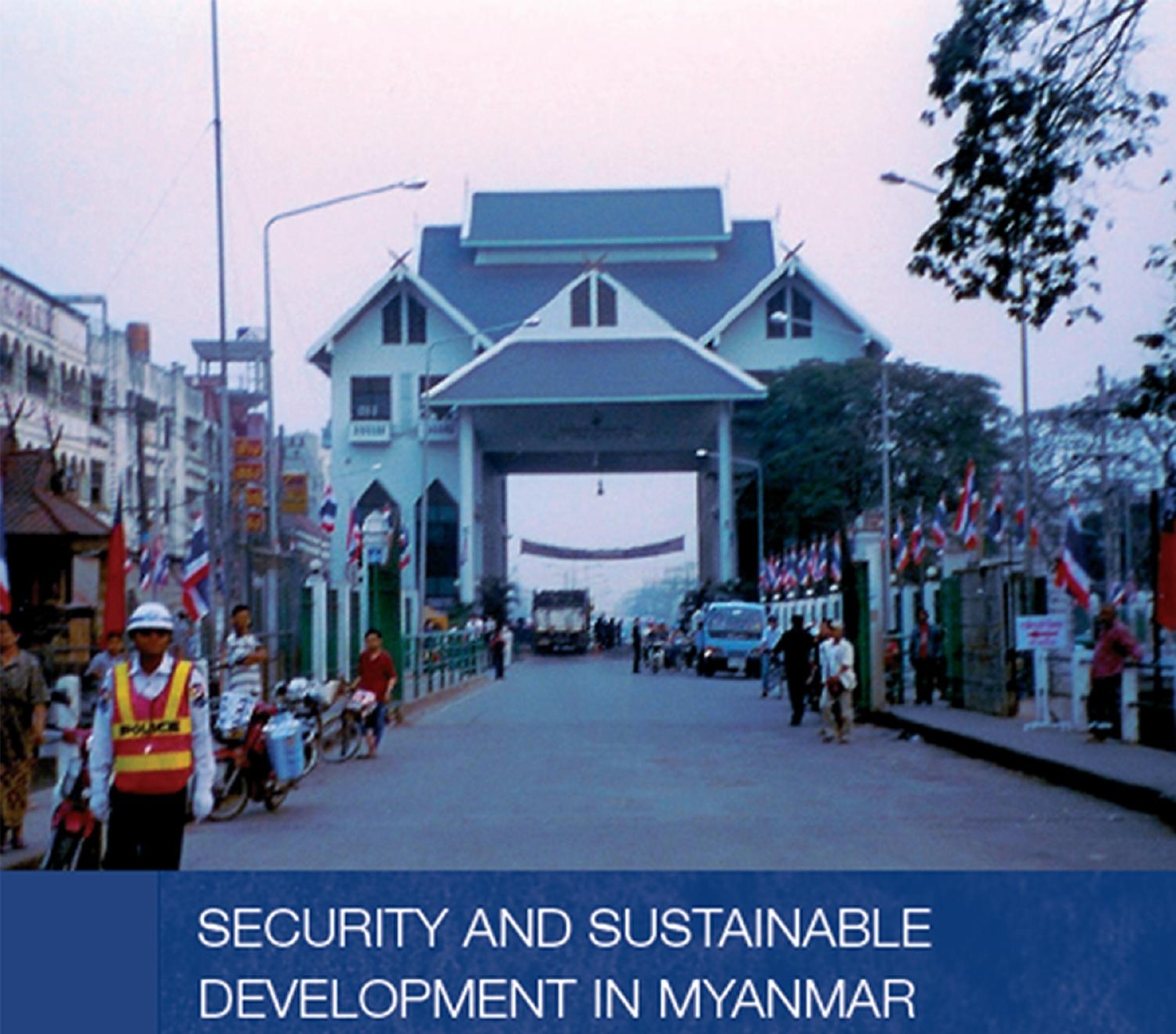

Helen James 


\section{Security and Sustainable Development in Myanmar}

This book examines security in Myanmar, focusing in particular on Myanmar's response to the international policies which have impacted on its development since 1988. It analyses the nexus between political poverty and economic poverty, arguing that Myanmar's endemic poverty is not merely a collection of unenviable socio-economic indices, but it is also a function of 'political' poverty and of the lack of 'capabilities' for the general population to participate fully in the nation's governance, resources and future. It demonstrates that freedom from want and freedom from fear (of the regime) are intimately related, and that economic insecurity is a product of the political insecurity that arises from a lack of secure property rights, a modern legal system, an independent judiciary and the opportunity for most citizens to participate fully in the political governance of their country.

Helen James is a Visiting Fellow with the Research School of Pacific and Asian Studies, The Australian National University. She researches Thai and Myanmar history, politics and international relations with particular attention to civil society, human security, governance and sustainable development. 


\section{Routledge Contemporary Southeast Asia Series}

1 Land Tenure, Conservation and Development in Southeast Asia Peter Eaton

2 The Politics of IndonesiaMalaysia Relations

One kin, two nations Joseph Chinyong Liow

3 Governance and Civil Society in Myanmar

Education, health and environment Helen James

4 Regionalism in Post-Suharto Indonesia

Edited by Maribeth Erb, Priyambudi Sulistiyanto and Carole Faucher

5 Living with Transition in Laos Market integration in Southeast Asia Jonathan Rigg

6 Christianity, Islam and Nationalism in Indonesia Charles E. Farhadian
7 Violent Conflicts in Indonesia Analysis, representation, resolution Edited by Charles A. Coppel

8 Revolution, Reform and Regionalism in Southeast Asia

Cambodia, Laos and Vietnam

Ronald Bruce St John

9 The Politics of Tyranny in Singapore and Burma

Aristotle and the rhetoric of benevolent despotism Stephen McCarthy

10 Ageing in Singapore Service needs and the State Peggy Teo, Kalyani Mehta, Thang Leng Leng and Angelique Chan

11 Security and Sustainable Development in Myanmar Helen James 


\title{
Security and Sustainable Development in Myanmar
}

\author{
Helen James
}

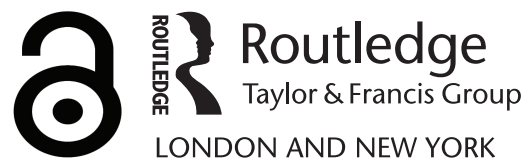


First published 2006 by Routledge

Published 2017 by Routledge

2 Park Square, Milton Park, Abingdon, Oxon OX14 4RN

711 Third Avenue, New York, NY 10017, USA

Routledge is an imprint of the Taylor \& Francis Group, an informa business

Copyright (C) 2006 Helen James

Typeset in Times New Roman by

Newgen Imaging Systems (P) Ltd, Chennai, India

The Open Access version of this book, available at www.tandfebooks.com, has been made available under a Creative Commons Attribution-Non

Commercial-No Derivatives 4.0 license.

British Library Cataloguing in Publication Data

A catalogue record for this book is available

from the British Library

\section{Library of Congress Cataloging in Publication Data}

James, Helen, 1947-

Security and sustainable development in Myanmar / Helen James. p.cm. - (Routledge contemporary Southeast Asia series; 11)

Includes bibliographical references and index.

1. Human rights - Burma. 2. Social rights - Burma. 3. Internal security - Burma. 4. Sustainable development - Political aspects Burma. 5. Civil society - Burma. 6. Burma - Politics and government $-1988-7$. Burma - Social policy. 8. Burma - Economic policy $-1988-9$. Burma - Foreign relations. I. Title. II. Series.

JC599.B87 J36 2006

338.9591'07-dc22

2006010008

ISBN13: 978-0-415-35559-9 (hbk) 
This book is dedicated to

The Tuesday Club

and absent friends 


\section{Contents}

List of plates viii

Foreword ix

Preface xi

Acknowledgements xiii

List of abbreviations $\quad \mathrm{xV}$

Map of Myanmar xvii

Prologue 1

1 Introduction: holistic and human security - concepts and contexts $\quad 8$

2 The security discourse in Myanmar: regime, state and people

3 The seven horsemen of the apocalypse: strategies for effective poverty alleviation amongst the peoples of the poppy cultures

4 Myanmar's external relations in regional context: security enhancement

5 Myanmar and the West: sanctions, engagement and security

6 Civil society and the political ecology of sustainable development: empowerment, opportunity and participation

7 Conclusion: towards a more civil society?

Notes

Bibliography

Index 


\section{Plates}

3.1 Mong Pauk hospital on Myanmar-China border 62

3.2 Yong Kha hospital and market gardens 63

3.3 Front view of Yong Kha hospital 63

3.4 Helen James with the United Wa State Army (UWSA) 64

3.5 Lunch outside Kengtung 64

3.6 Ethnic minority (Shan) women, Kengtung market 65

3.7 Helen James, Kengtung hill 66

3.8 The tallest tree, 500 metres in height, Kengtung hill - used

3.9 Villagers Mong Pyan (1) 69

3.10 Villagers Mong Pyan (2) 69

3.11 Mong Pyan welcome band, villagers and helicopter $\quad 70$

3.12 Mong Pyan truck and welcome (1) 71

3.13 Mong Pyan truck and welcome (2) 71

3.14 Welcome by children, Wan Hong poppy replacement project 72

3.15 Yong Kha village project $\quad 75$

3.16 Yong Kha school and market gardens 76

3.17 Yong Kha school and school bell made from wheel hub 76

3.18 Nurses Yong Kha hospital 77

3.19 Patient examination room Yong Kha hospital 77

3.20 Young soldiers in the UWSA - Wan Hong welcome band 78

3.21 Welcome at Wan Hong poppy replacement project, showing fruit (Mandarin) trees, in background 78

3.22 Provincial Headquarters, Wa Special Region No. 1, showing
fruit orchards in background

3.23 UNODC funded water viaduct for rice fields - Mong Ka $\quad 80$

3.24 Lahu dancers Kengtung hotel (1) 81

3.25 Lahu dancers Kengtung hotel (2) 81

3.26 Tachilek-Mae Sai Border Gate, Thai-Myanmar Border 84 


\section{Foreword}

Myanmar is a curious and sad example of a poor and weak state struggling with the ever-increasing changes and growing demands of the modern world. As Dr James points out, its history, its political and cultural sensitivity and its fissiporous character have made this struggle particularly difficult and demanding. The consequence has been a series of coups and repressive governments, followed by isolation by the West and yet further impoverishment of Myanmar's people and still greater paranoia amongst the Myanmar military elite.

It is this dilemma for powerful Western states, led by the United States, and for the leaders of the ASEAN and other states, which surround Myanmar, that Dr James sets out to place in its historical context and to illuminate. The author lived in Thailand for many years and has travelled extensively in Myanmar. She is one of the few Western experts on the country. Her reflections on all concerned, successive administrations in Washington, ASEAN governments and the Myanmar armed forces challenge much of the conventional wisdom and are all the more valuable as a consequence. Her conclusions about the short-term prospects are gloomy; change in the military leadership offers the best prospects for the establishment of a fairer, more open and thus more prosperous society in Myanmar. Unfortunately, since General Khin Nyunt's dismissal, the situation has actually deteriorated, although the progress he made in quieting many of the groups fighting central control has not been reversed.

Meanwhile Myanmar tries to balance its relationship between the growing power of China on one side and the growing power of India on the other. China has increased its investment in the country to fill the vacuum left by the withdrawal of United States' aid and investment. India has also been helpful fearing that Sino-Myanmar rapprochement and Pakistani hostility could give it enemies on almost all sides. Thailand is supportive because it dreads instability in Myanmar leading to massive refugee flows. Japan has been Myanmar's largest aid donor and it is salutary for a Western reader to note Dr James' suggestion that Japanese friendship can be traced back to Tokyo's invasion of the country in 1942 and the 100,000 Japanese who died there. British and Australian readers may have 


\section{$\mathrm{x}$ Foreword}

rather different memories of Japanese actions and Dr James' insights add to the richness and interest of her text. Anyone reading what she has to say and meditating her wide literary and political allusions will emerge challenged and enlightened.

Philip Towle

Centre of International Studies University of Cambridge November 2005 


\section{Preface}

This book is a companion to my earlier volume, Governance and Civil Society in Myanmar: Education, Health and Environment (London: RoutledgeCurzon, 2005). Whereas that book examined Myanmar's domestic policies and the framework in which such policies were being implemented, the current volume, Security and Sustainable Development in Myanmar, seeks to examine the country's response to the international policies that have impacted on its development since 1988. The short-lived 'reform' program (1997-2004) has come to a halt. By walking a tightrope between power groups that incline to no compromise with either the domestic opposition or the international community (which has been urging it to greater acceptance of democratic norms), the small band of internationally savvy technocrats who were conscious that the country could not remain frozen in the aspic of its socialist past, sought to transform the country from within; today, most are either in jail or purged from their posts. For all sides in the acrimonious debate that has ensued over the future governance of Myanmar, the concept of security has been central; whether security from external invasion and internal subversion, international pressure, cyber-attacks by the diaspora, or from the arbitrariness of the oppressive authoritarian state apparatus, which, for over 40 years, has made the lives of ordinary (and not so ordinary) Myanmar/Burmese citizens 'insecure'. At the time of writing, the country is the object of a concerted effort by its antagonists in the international arena to activate measures that they hope could lead to UN Security Council sanctioned intervention. That such measures are unlikely to succeed owing to the composition of the Security Council and the counter-policies Myanmar has pursued internationally in aligning itself with China, will not diminish the country's sense of being under siege. In such an environment, the well-being of the majority of Myanmar's people is again hostage to the larger agenda of the major powers who control world politics.

Myanmar's endemic poverty is not only a collection of unenviable socioeconomic indices. It is also a function of 'political' poverty, of the lack of 'capabilities' for the general population to participate fully in the nation's governance, resources and future. This book examines the essentially concomitant nature of 'freedom from fear' and 'freedom from want' and how one is a function of the other. Economic insecurity is a product of political insecurity, of lack of secure property rights, lack of a modern legal system, lack of an independent 
judiciary and lack of the opportunity for most citizens to participate fully in the political governance of their country. 'Famines', both literally and symbolically, as Sen and Dreze (1999b) have shown, are peculiarly absent from countries where democratic governance is the norm, because the institutional underpinnings are usually in place to respond promptly to unexpected crises in a manner consistent with the duty of government to exercise its 'responsibility to protect' its citizens.

Myanmar is a country whose dearest wish is to be 'secure', and to be counted an equal among other equal modern societies, yet imposes dire 'insecurity' on its citizens. Enhancing the capabilities of the country requires its leaders to recognize that the capabilities of its citizens need to be enhanced to realize their full potential, if the country is again to be accorded the respect it deserves amongst the family of nations. Only then will the country really be secure. At present, the intergenerational promise of the sustainable development Agenda 21 programme seems bitterly ironic, bequeathing, as it does, a legacy of endemic poverty, malnutrition, poorly resourced education system and civil conflict. If this book has a message it is that Myanmar needs to put aside its policies of 'securitization' of the country's political, economic and social life, and empower its people to be able to benefit fully from participation in the international community.

Like its predecessor, this book has had a long gestation. Research commenced in 1996 was initially set aside while other projects were completed. Sixteen visits to the country since that time have included extensive travel by road and by air to the north and north-east amongst the 'poppy cultures' of Shan State, Eastern Shan State and the Wa-Kokang special region, as well as explorations of the central 'dry zone' from Mandalay to Meiktila and Bagan, the Delta region and the Eastern perimeter bordering Thailand. Whilst there are undoubtedly pockets of vast wealth in the country coalescing with the 'newly rich' contractor-commercial classes, the overall life experience of more than 50 per cent of the people is of endemic poverty, of the struggle to live from day to day - all this in the face of an obvious plenitude of natural resources, largely untapped. Macroeconomic and microeconomic reform are urgently needed; but the institutional developments to spread the subsequent benefits to the people are also necessary, lest the benefits continue to accrue to only a small minority (as was the case in the 1960s and 1970s amongst Myanmar's South-East Asian neighbours). 


\section{Acknowledgements}

My thanks are due to many people for their generous support during the writing of this book. First, to The Australian National University, whose grant of several Visiting Fellowships (2001-5) in the Research School of Pacific and Asian Studies (RSPAS), the Asia-Pacific School of Economics and Government (APSEG) and the Research School of Social Sciences (RSSS) has provided the space and time for the research and writing to be undertaken. I would particularly like to thank Professor James J. Fox, Director of RSPAS (1998-2006); Professor Andrew Macintyre, Director of APSEG; Professor Desley Deacon, former head of the History Program RSSS, ANU and Professor Ron Duncan, Executive Director of the Institute for Advanced Studies in Development and Governance, University of the South Pacific for their continuing interest in and support for my work, as well as for the time they have generously given in discussing Myanmar issues.

Second, I wish to express my deep gratitude to Cambridge University, Centre of International Studies and Clare Hall, which kindly elected me to two Visiting Fellowships (2003-4), during the course of which the research on various manuscript collections in the Cambridge University Libraries was pursued. I would like to express my deep appreciation particularly to Dr Philip Towle and Professor James Mayall, former Directors of the Centre of International Studies, Cambridge University, for their friendship, faith and guidance during this time; and to Professor Ekhard Salje, President of Clare Hall and Mrs Lisa Salje, for their sustained interest in Myanmar during my time at Clare Hall. I would also like to express my gratitude to Professor Geoffrey Hawthorne, Vice-President of Clare Hall, and Head of the Department of Social and Political Studies, Cambridge University, for his interest and support both in the bestowal of the Visiting Fellowship at Clare Hall and in the successful completion of the project. Discussions with Professor Hawthorne over dinner and subsequent to my return from the 'Golden Triangle' assisted me to refine some of my approaches to the problems of political development in Myanmar. Thanks are also due to a large number of friends amongst the fellowship at Clare Hall: to Dr Gerald Chan, Victoria University, Wellington; Mrs Edith Norsett and Professor Syvert Norsett, Trondheim University, Norway; to Emeritus Fellow Dr Audrey Glauert and her friends at Amnesty International (Cambridge Branch); to Mr David Rooney 
whose mutual interest in Orde Wingate and his Chindits led to some stimulating dinner discussions and to Ms Elizabeth Ramsden, College Secretary at Clare Hall, whose friendship contributed greatly to the pleasure with which the work was undertaken.

My deep appreciation must also be expressed to Mr Godfrey Waller and his staff in the manuscripts room of Cambridge University Library for their courtesy and unfailing kindness during the many months of my research. Godfrey's guided tour around the inner sanctums of the library to view the Scott collection in its magnificent cabinets, is a memory I shall always treasure. Much of the remaining research was undertaken in the Petherick Room of the National Library of Australia (NLA) where its superb collections of Asia-Pacific materials have sustained this work. My deep appreciation is due to the research services librarians at the NLA, particularly Andrew Sergeant, Mary Gosling, Paul Livingston and Ursula Macdermott for their courtesy and cheerfulness in assisting with numerous enquiries.

My very deep gratitude is also due to Ms Alyson Bailes, Director of the Swedish International Peace Research Institute (SIPRI), Stockholm, and her staff for their unfailing kindness, thoughtfulness and consideration during my time with them. Alyson's grant of a Visiting Fellowship in the spring of 2004 enabled me to carry out research on the effect of sanctions on fragile states. That work forms an essential part of this book and I hope in future to make a return visit when the next part of the project is underway.

Various ideas in this book were presented as seminars at SIPRI, CIS and Clare Hall, Cambridge University, APSEG, RSPAS and RSSS, ANU during the period 2003-5. My thanks are due to the participants in those seminars for their comments and discussions which assisted in the final distillation of the conceptual framework for the book.

For my many Myanmar friends, both within and without the country, who have shared ideas, meals, journeys, shopping trips, temple visits and rides in helicopters over Myanmar's far north, this book is for you - I hope you have a brighter and more secure future.

Finally, I must thank my beloved family for their continued support and encouragement, their willingness to hold the fort during my various absences overseas and their generosity in enabling me to have the opportunity to complete this book. As always, any errors are mine alone. 


\section{Abbreviations}

$\begin{array}{ll}\text { ABSDF } & \text { All Burma Students Democratic Front } \\ \text { ADB } & \text { Asian Development Bank } \\ \text { AFPFL } & \text { Anti-Fascist Peoples Freedom League } \\ \text { AFTA } & \text { Asian Free Trade Agreement } \\ \text { ALTSEAN } & \text { Alternate ASEAN } \\ \text { ARF } & \text { ASEAN Regional Forum } \\ \text { ASEAN } & \text { Association of Southeast Asian Nations } \\ \text { ASEM } & \text { Asia-Europe Meeting } \\ \text { BIMST-EC } & \text { Bangladesh, India, Myanmar, Sri Lanka and Thailand-Economic } \\ & \text { Cooperation } \\ \text { BSPP } & \text { Burma Socialist Program Party } \\ \text { CCDAC } & \text { Central Committee for Drug Abuse Control } \\ \text { CSCE } & \text { Commission on Security and Cooperation in Europe } \\ \text { DDSI } & \text { Directorate of Defence Services Intelligence } \\ \text { GCBA } & \text { General Council of Buddhist Associations } \\ \text { GCSS } & \text { General Council of Sangha Sametgyis } \\ \text { GMS } & \text { Greater Mekong Sub-region } \\ \text { ICCPR } & \text { International Covenant on Civil and Political Rights } \\ \text { ICESCR } & \text { International Covenant on Economic Social and Cultural Rights } \\ \text { ICISS } & \text { International Commission on Intervention and State Sovereignty } \\ \text { IMF } & \text { International Monetary Fund } \\ \text { IMTFE } & \text { International Military Tribunal for the Far East } \\ \text { INGOs } & \text { International non-governmental organizations } \\ \text { IOC } & \text { International Olympic Committee } \\ \text { KCIE } & \text { Knight Commander of the Indian Empire } \\ \text { KIO } & \text { Kachin Independence Organization } \\ \text { KKY } & \text { Ka Kwe Ye } \\ \text { KMT } & \text { Kuomintang } \\ \text { LDC } & \text { Least Developed Countries } \\ \text { MMCWA } & \text { Myanmar Maternal and Child Welfare Association } \\ \text { NCEA } & \text { National Commission for Environmental Affairs } \\ \text { NCGUB } & \text { National Coalition Government of the Union of Burma } \\ \text { NGOs } & \text { Non-governmental organizations } \\ & \end{array}$


xvi Abbreviations

NLD National League for Democracy

OSCE Organization for Security and Cooperation in Europe

SLORC State Law and Order Restoration Council

SMOs Social Movement Organizations

SPDC State Peace and Development Council

TAC Treaty of Amity and Cooperation

UDHR Universal Declaration of Human Rights

UMFCCI Union of Myanmar Federation of Chambers of Commerce and Industry

UNCTAD United Nations Council on Trade and Development

UNDP United Nations Development Programme

UNODC United Nations Office of Drugs and Crime

USDA Union Solidarity Development Association

YMBA Young Men's Buddhist Association 


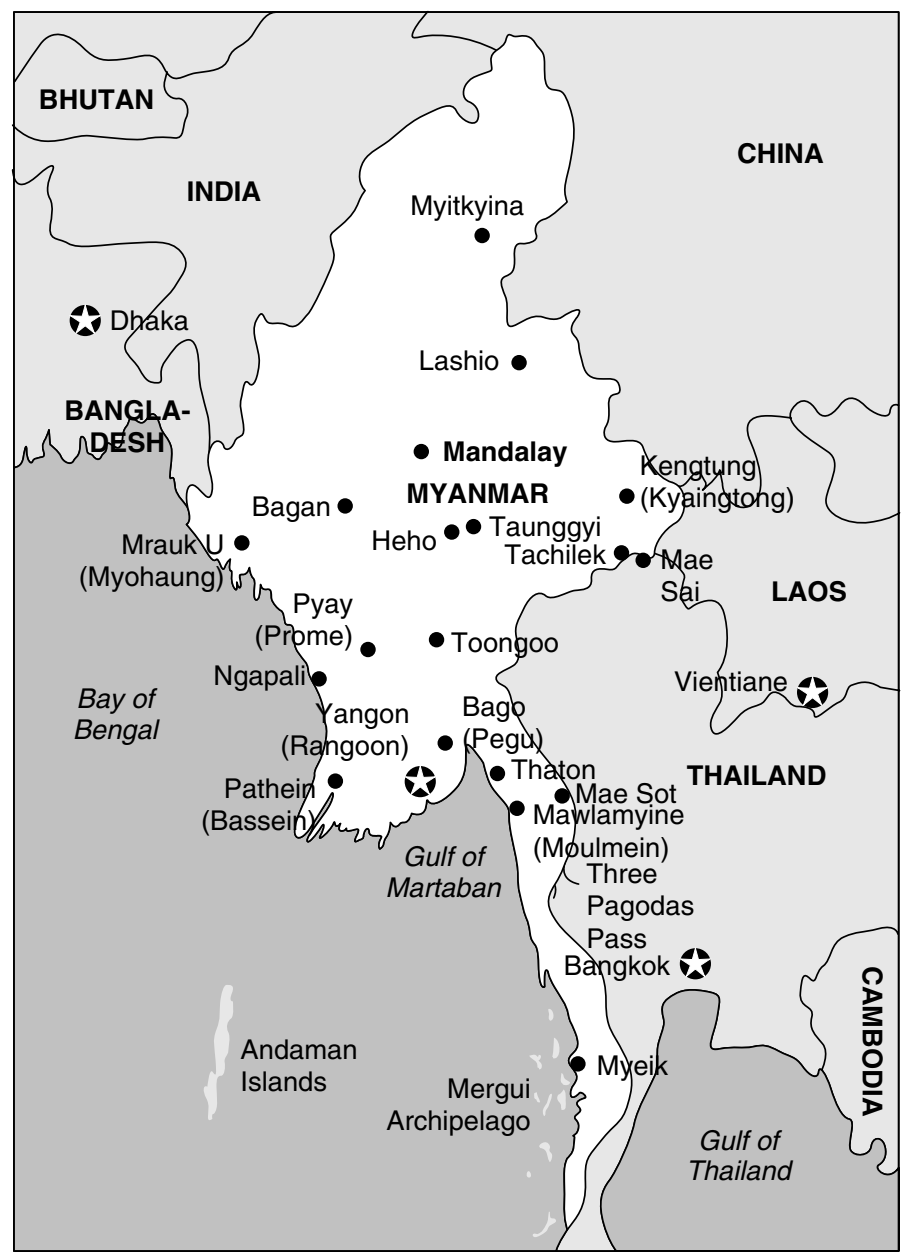

Map of Myanmar. 


\section{Prologue}

The security discourse in the state of Burma/Myanmar has typically focussed on regime and state perpetuation, sovereignty, peace and stability. Non-disintegration of the Union is the foremost of the state objectives printed on every copy of the New Light of Myanmar. These elements have traditionally formed the basis of the 'realist' paradigm of international relations theory. Since the United Nations Development Programme (UNDP) Human Development Report 1994 initiated the seven elements of the human security - as opposed to state security - concept, the security discourse in the Asia-Pacific has attempted to evolve from the common and collective security of the earlier Cold War era, to that of comprehensive security. However, this too is state-centric. There have been attempts to make the human security discourse non-state-centric, but careful analysis of this concept has concluded that freedom from want and freedom from fear are two sides of the same coin, and indeed need to be fostered by the state. This book takes the seven elements of the human security discourse to analyse their application in public policy in the context of Myanmar's transition to a peaceful, united, multiparty democracy. Thus the book will show that sustainable development in Myanmar is a code for freedom from fear of the state apparatus of repression through application of policies of empowerment and participatory practices as advocated by the global institutions of good governance, the World Bank, Organization for Economic Cooperation and Development (OECD), Asian Development Bank (ADB) etc. This book shows that the threats to the security of the state and the regime come from poverty, non-optimal relations with civil society and the minority peoples, from diseases such as HIV/AIDS, malaria and tuberculosis, from lack of a quality education system, from failure to address adequately environmental degradation, the drug trade and human trafficking. Conversely, addressing these 'threats' requires improved governance, development of civil society, effective poverty alleviation through economic development - itself requiring good macroeconomic and microeconomic management - ongoing environmental conservation measures, continued economic reforms, and concerted drug suppression and poppy-replacement operations. Even more than these measures - which I call the seven horsemen of the apocalypse - I show that the security of the people and the security of the state are in symbiotic relationship with each other. The state cannot be secure unless the security of the people is assured; thus freedom from want and freedom from fear are in effect one and the 


\section{Prologue}

same. I argue that public policies supporting opportunity, empowerment and participatory practices are the capstone of both human and state/regime security, leading to a redefinition of the concept of security as holistic security.

My analysis will perforce include detailed assessments of human rights issues; the drug trade, relations with the minority peoples and programmes for their inclusion in a multi-ethnic state; political reforms and economic and social issues. The overall theme of the book will focus on economic development and educational development as prerequisites to formation of a context able to produce and support a viable multiparty democratic state able to enhance and protect the well-being of its citizens, not fear them. Holistic security, in effect is predicated on the notion that the security and longevity of the state are dependent on the security and well-being of its citizens.

This book includes an analysis of Burma/Myanmar's external as well as internal relations in the context of both the new regional and international security discourses. Thus the state's relations with its Asian neighbours - China, Japan, India and Thailand - as well as its membership in various regional bodies the ASEAN Regional Forum (ARF), Association of Southeast Asian Nations (ASEAN), Bangladesh, India, Myanmar, Sri Lanka and Thailand-Economic Cooperations (BIMST-EC), the Mekong Sub-region Development Project - will be analysed in terms of this evolving security discourse. I also take into account the state of Myanmar's relations with the USA, EU and UK in terms of the economic sanctions imposed and Myanmar's international position, as well as its cooperation in the War on Terror.

In this book I draw on the theoretical frameworks of political science, international relations, political and social anthropology, development studies and historical research. I also take into account the work of Amartya Sen, Martha Nussbaum, John Martinussen and Jagdish Bhagwati on poverty alleviation and sustainable development; that of Muthiah Alagappa, Barry Buzan, Alan Dupont, Stuart Harris, Ramesh Thakur and Amitav Acharya on Asian security practice; the policy positions of the World Bank, UNDP and international agencies in seeking to encourage transitional states to embrace the principles of empowerment, participatory practices and enhancement of opportunity for their citizens. I look at the role of civil society in sustaining a redefined 'secure' state, and present a way forward towards achievement of 'freedom from want and freedom from fear' in the state of Burma/Myanmar which, since the loss of its independence to Britain in the nineteenth century, has always put a premium on state and regime security, but not the security of its people. This book says that the security of an empowered citizenry able to participate in the decisions affecting their governance will in turn engender the security of the state. Holistic security presupposes that whilst state/regime security and security of the people are in symbiotic relationship, it is the latter which is dominant in strong, successful states.

This book is timely in view of the changing international and Asia-Pacific security discourse, the present political impasse in Myanmar following the 30 May 2003 incident, and the urgent need for sustained political, economic and social reforms in this key regional state. 
This book is presented in seven chapters, plus an initial prologue. The content focuses on the security discourse in Myanmar since independence from Britain on 4 January 1948 and future policy directions. In my analysis, the role of civil society in fostering improved human security and the concomitant sustainable political and socio-economic development is closely examined. I use the term, 'Myanmar', to denote the country since 1989, as this is its officially registered name with the United Nations. 'Burma' is used to denote the country as it was prior to this date. I occasionally use the terms, 'Myanmar/Burma' or 'Burma/Myanmar' where the discussion is focusing on differently held views of the country by the government and its antagonists. Since many other post-colonial countries have exercised their right to slough off the former colonial terminology, I see no reason why Myanmar also should not be enabled to exercise this right. The government's political opponents can of course choose to continue using the former colonial name if they wish; in doing so, they make a recognizable political statement. It might be instructive to note, that in 1893, as the British colonial administration in Burma thought it was about to put an end to the first phase of concerted Burmese resistance to the takeover of their country, a certain C. T. Paske, published an otherwise unremarkable book entitled, Myamma: $A$ Retrospect of Life and Travel in Lower Burmah, London: W. H. Allen \& Co. Even Paske's very Euro-centric book projects cognizance of the original name of the country. Burma/Myanmar seems to be a case of 'Plus ça change...'. And then, unexpectedly, Myanmar seems to have the capacity to surprise even the most experienced Burma watchers.

\section{Focus and philosophy}

Myanmar (Burma) has had a turbulent post-colonial history. Twelve years of parliamentary democracy (1948-62) under the late Premier U Nu, ended with the military takeover on 2 March 1962 led by the late General Ne Win. An unfortunate legacy of this period, stemming perhaps even from the colonial government during the Dyarchy (1937-41) period, and exacerbated by the bitter civil war (1948-89) is an enduring suspicion of the motivations of civilian politicians. Such suspicions amongst the country's armed forces have long since atrophied and become part of the standard ideology justifying continued military governance in Myanmar - the need to prevent disintegration of the Union; the need to protect national sovereignty. Such a perspective was an article of faith for General $\mathrm{Ne}$ Win and continued in the pronouncements of his successors. Ne Win's retirement in July 1987 was followed by civil disturbances which culminated in August 1988 during which a large number of citizens died. Responding to obvious pressure for change, the legal framework for the socialist-style command economy was replaced by laws initiating the market economy which continues, haltingly, to the present time. A new electoral law promulgated on 31 May 1989 prepared the way for possible political change through the holding of multiparty elections. But the promise was short lived. Refusal of the military government to acknowledge the results of multiparty elections held on 27 May 1990 has meant that, since that 


\section{Prologue}

time, the attention of international scholars has largely been directed to the political situation and human rights issues. Comparatively little attention has been given to the socio-economic institutional changes needed to underpin a viable multiparty democracy. In view of the changing international security discourse since September 11, 2001, this book looks at the security issues in Myanmar in both international and national context and at the internal regeneration required to achieve holistic security for both people and state.

This book breaks new ground and contributes significant new interpretation of the security concept in Myanmar. It projects a way forward by which the political impasse in Myanmar might be resolved within the context of the country's economic and social development. It suggests that a non-violent resolution of the political impasse, particularly in view of the present crisis, needs to be accompanied by comparable strengthening of the civil institutions, civil society and the social structures to promote economic development and effective poverty alleviation in this overwhelmingly agrarian country, more than 50 per cent of whose citizens live below the World Bank designated poverty line of less than USD 1 per day, and whose currency, in October 2005, had fallen to 1,250 kyat to the US dollar (market rate, compared to the Myanmar government rate of 6 kyat to the US dollar).

\section{Freedom from want and freedom from fear}

This book explores the integral nature of both 'freedoms' - 'freedom from want' and 'freedom from fear'. It is not considered valid to privilege either over the other. People struggling to overcome destitution, malnutrition and disease are primarily more concerned with the difficulties of daily survival than they are with casting a ballot at the next election; on the other hand, political empowerment, the capacity to participate in the nation's life through casting one's vote at the ballot box may result in electing a government with the capacity to put in place the institutions which will obviate food shortages, provide quality health care for all, alleviate poverty through proper macroeconomic reforms which generate employment and implement measures to curb corruption. Elections, by themselves, however, are no guarantee that appropriate institutional arrangements will be established to sustain human security; respect for the rule of law, an independent judiciary, freedom of association and the press and secure property rights are all part of the mix of required ingredients to make freedom from fear practicable. In late 2005, Reporters Sans Frontieres ranked Myanmar at 163 out of 167 nations in terms of Freedom of the Press; North Korea was ranked 167. Economic development of itself also should not be seen as a substitute for political empowerment; it is, however, an essential ingredient in fostering and sustaining the political rights necessary to engender respect for human rights. There is increasingly amongst both established democracies and the incipient demi-democracies, a cynical public policy perspective which plays to the notion that people do not mind if their political rights are curtailed as long as the economy is buoyant. This is an unfortunate policy perspective. Oppression originates from curtailed 
political rights; freedom from fear requires constant vigilance on the part of those citizens who enjoy political rights, that these are not inappropriately submerged in the freedom from want formulae. When such a fusion occurs, the democratic pendulum slides along the political parabola towards dictatorship and a correction is required if the polity is not to sow the seeds of its own destruction, as did fifth century BC Athens in face of the Spartan challenge.

This critical juxtaposition of values was highlighted by Daw Aung San Suu Kyi, awarded the Nobel Peace prize on 14 October 1991. Now an icon of the democracy movement in Burma/Myanmar, she articulated the linkage between political rights and human security. In Freedom from Fear (1991) she writes that even the least political citizens will say,

'We just want to be able to go about our own business freely and peacefully, not doing anybody any harm, just earning a decent living without anxiety and fear.' In other words they want the basic human rights which would guarantee a tranquil, dignified existence free from want and fear.

(Aung San Suu Kyi 1991: 173)

That such a transformation in governance resides in a transformation in the value systems governing the country's institutions is one of her major insights into the country's long-term problems. The people of Burma [sic], she writes, 'want not just a change of government but a change in political values' in order to move the polity away from the indigenous authoritarianism which has conditioned their lives since pre-colonial times. Thus, she states,

The unhappy legacies of authoritarianism can be removed only if the concept of absolute power as the basis of government is replaced by the concept of confidence as the mainspring of political authority...

(Aung San Suu Kyi 1991: 178)

But is this iconic figure the 'woman of destiny', as Joseph Silverstein asked? In 1991, in this same volume, this noted American scholar of independent Burma, identified the paradox in Suu Kyi's situation. Yet untried in a responsible national leadership role, kept from the people through several periods of house arrest since 1989, Silverstein writes,

[S]he stands to inherit more problems than her father imagined; and although she is intelligent and informed about Burma, she has given no clear answers to the questions of how democracy can be institutionalized, how national unity can be achieved, how the economy can be improved or how the violations of human and political rights by the military in the past and present will be rectified. The Burmese people have been in search of leadership since the death of Aung San and many believe that they have found it in his daughter. So long as she remains untried in a responsible position and isolated from the people, they will continue to believe that she is the one who can set them on 


\section{Prologue}

a new course. But until she is given the chance to use her new-found skills of democratic politics in the crucible of parliamentary politics and bears the responsibility for her decisions, no one will know if she is destined to lead Burma towards a new and better life than its peoples have had or if she will be forced to compromise and accept the realities of Burma that developed over the past forty-three years.

(Silverstein, in Aung San Suu Kyi

1991: 282)

Despite brief periods of freedom from house arrest since 1995, ending with the debacle at Depiyin on 30 May 2003 when her cavalcade in Upper Myanmar came under attack by groups supporting the government, Daw Aung San Suu Kyi appears further than ever from being able to form a government. Political violence has plagued the independent state since its inception and thwarted its early promise of a prosperous life for the people.

Writing in 1950, as the post-independence civil war was still raging, Albert Moscotti saw a 'medieval Burmese society' (Moscotti 1950: 150) on which the British colonial administration had sought, unsuccessfully to graft Western political and economic institutions without taking account of the cultural underpinning in which such institutions would be operating. Measures introduced after 1917 and continuing until 1937 increasingly ran up against the boycott tactics of the nationalist movement and the religiously based civil society groups - the Young Men's Buddhist Association (YMBA); the General Council of Burmese Associations (GCBA) and the General Council of Sangha Sametgyis (GCSS). Some 12,000 affiliated associations participated in the 1921 GCBA conference in Mandalay (James 2004c: 540). From non-political origins, these groups became more overtly political after 1923. Through the pongyis (the Buddhist monks) they fed into the village association (athin) movement which became so deeply involved in the boycott (hartal or non-cooperation) movement and local level payback crimes that the British authorities enacted legislation to curb them (Moscotti 1950: 30). Such legislation also impacted adversely on personal freedoms, and the way justice was administered, a fact not lost on the nationalist movement (ibid.: 121). But the political reforms of the colonial administration did not give the Burmese people experience at the national level with key portfolios such as Defense and Foreign Affairs, two key functions which draw much of the criticism of contemporary Burma/Myanmar. Moscotti considers that the political reforms introduced in the colonial era limited Burmese political experience to the local level of the administrative apparatus and did not adequately prepare for the postindependence reality. 'How could they?' he asks. Their objective was to delegate some functions to the Burmese (education, forests, posts and telegraphs) whilst keeping control of the economy in British and non-indigenous minority hands. The resulting plural society discriminated against the majority Burmese in economic life, in the defense forces, in the civil service and in political participation. Moscotti notes that as the nationalist movement got underway, its leaders became 
convinced that the key to restoring national sovereignty was not merely political reform but also economic.

As the nationalist movement gained momentum there was an increasing awareness among Burmese leaders that the transition from the status of a colony to that of a modern state transcended mere political reform. They insisted that Burmans must also take a significant part in the trade and commerce of the country and share more fully in the returns of the national economy.

(Moscotti 1950: 130)

Sovereignty was being expressed in both political and economic terms. Policies pursued in the post-independence era have a direct correlation with this preindependence experience of economic exploitation and political disempowerment. The subsequent legacy of ethnic conflict, high crime rates, political factionalism, corruption and social malaise has still to be resolved. It has provided justification in the official ideology for continued military governance and fear of freedoms.

The question of which comes first - political reform or economic development in order to enhance human security, is an 'egg and chicken' question. Burma/Myanmar has been waiting over 50 years to have a future and the societal problems are now so entrenched that it is immoral from one perspective, and impracticable from another, to put the future of over 50 million people on hold pending resolution of the political impasse. Freedom from want and freedom from fear are two aspects of the same issue; both must be satisfied if human security is to be enhanced. 


\section{Introduction \\ Holistic and human \\ security - concepts and contexts}

\section{Introduction}

Human security became prominent in the security lexicon in the mid-1990s, a product of the international responses to fearful scenes of communal and ethnic violence in the Balkans after the fragmentation of the former socialist republic of Yugoslavia. Largely sponsored by the foreign policy establishments of Japan, Canada and Australia, the human security concept aimed to promote the notion that human well-being is of primary importance, whilst state or regime security are secondary to this main objective. The approach gained considerable currency, especially in UN circles, and has figured prominently in the speeches of UN leaders. In 2001, Kofi Annan, Secretary General of the UN, set the fundamental principles of human security in the context of world politics as he saw the situation at that time. He highlighted the key security concepts which have engaged the attention of policy makers since the UNDP Human Development Report 1994 identified seven primary sources of threats to human well-being. Kofi Annan stated,

During the Cold War, security tended to be defined almost entirely in terms of military might and the balance of terror. Today, we know that 'security' means far more than the absence of conflict. We also have a greater appreciation for non-military sources of conflict. We know that lasting peace requires a broader vision encompassing areas such as education and health, democracy and human rights, protection against environmental degradation, and the proliferation of deadly weapons. We know that we cannot be secure amidst starvation, that we cannot build peace without alleviating poverty, and that we cannot build freedom on foundations of injustice. These pillars of what we now understand as the people-centred concept of 'human security' are interrelated and mutually re-inforcing. And perhaps most crucially, no country, however powerful, can achieve human security on its own, and none is exempt from risks and costs if it chooses to do without the multilateral cooperation that can help us reach this goal.

(McRae and Hubert 2001: xix-xx) 
From this perspective, human security privileges the human being, the non-military aspects of security, in contrast to the parallel or earlier security concepts comprehensive, cooperative, and common security - which privilege the state. For Kofi Annan, human security puts people first, and should be at the heart of the international decision-making mechanisms which address common threats to human well-being originating from a range of trans-state and intra-state sources. These include both man-made and natural disasters such as genocide, terrorism and human trafficking, drugs, HIV/AIDS and the SARS virus, environmental degradation, endemic poverty, state collapse and the catastrophic consequences of the 26 December 2004 earthquake off northern Sumatra and subsequent tsunami which wreaked havoc on 10 countries along the Indian Ocean rim and caused over 290,000 deaths. The list is indicative rather than exhaustive. All of these threats to human security may have intra-state origins with trans-state consequences. All require multilateral, international cooperation and resources to combat and to seek to develop practicable solutions.

This perspective presupposes that the risks to human security from inter-state conflict have reduced, whilst those from trans-state or intra-state conflict have increased. The statistics cited by the UNDP Human Development Report 2002 support this view: over 170 million people died in intra-state conflicts during the twentieth century, far more than in inter-state conflicts (UNDP 2002: 5). However, since the formal end of the Cold War in 1989, the anticipated peace dividend is perceived not to have been realized; the succeeding 15 years have been characterized by a very high incidence of intra-state violence originating in ethnic or ideological conflict, or political power struggles in which over 80 per cent of the casualties have been civilians, many of whom have been 'targeted with intent' (McRae and Hubert 2001: 4). The UNDP Report states,

In the 1990 s conflicts between countries killed about 220,000 people, a drop of nearly two-thirds from the 1980s. But civil conflicts are more damaging than ever. In the $1990 \mathrm{~s}$ about 3.6 million people died in wars within states, and the number of refugees and internally displaced persons increased 50 per cent.

(UNDP 2002: 2)

Developing a set of international norms and principles to prevent these human tragedies should clearly be a priority of the international community. In the wake of the tsunami disaster of December 2004, and the worldwide outpouring of support for victims in the affected countries, steps are being taken to put in place in the Indian and Atlantic Oceans an early warning system parallel to the one operating from Hawaii which alerts the Pacific Rim countries to impending threats from such natural disasters. Profoundly affected by the scale of the destruction and the palpable human suffering, Australian Minister for Foreign Affairs, the Hon Alexander Downer, while visiting the disaster zone commented, 'It makes you feel that the international community is able to come together in the 
cause of humanity. It has touched the whole world and it is nice to see that the whole world can work together so constructively' (The Canberra Times, 5 January 2005 , p. 1). Working constructively within the wider international community to alleviate human suffering is perhaps the core value of the concept of human security. If the global initiatives to provide both immediate relief to the victims and longer-term reconstruction of the devastated communities prove to be effective, they will go a long way towards demonstrating that the concept of human security can be implemented in practicable ways.

\section{The human security discourse: freedom from fear and freedom from want}

Enhancing human security has been recognized as the principal role of the UN and its related agencies since its inception. Since the end of the Second World War, the principles to enhance human security have been expressed in a range of international initiatives - in the UN Charter, the 1948 Universal Declaration of Human Rights (UDHR), the four Geneva Conventions and two Additional Protocols on international humanitarian law and armed conflict; the 1948 Convention on the Prevention and Punishment of the Crime of Genocide; the two 1966 Covenants on civil and political and on social, economic and cultural rights and the 1998 initiative to establish an International Criminal Court. Together with a number of interrelated treaties, protocols and conventions they provide the institutional and legal framework which impels states to enhance the well-being of their citizens through their domestic public policies, if they also wish to be seen to be behaving responsibly in international affairs. This body of international law represents a concerted attempt by the 192 members of the United Nations to reify the right of human beings to be protected from inter-state, trans-state and intrastate sources of insecurity.

The human security discourse creates a special space in civil society - state relations in which state performance can be monitored and assessed. Recourse to states' rights and notions of national sovereignty, whilst still pre-eminent in international relations theories as the primary loci of relations between nation states, are no longer in themselves adequate measures of the efficacy of public policy, either in its domestic or international dimensions. Increasingly, what James Rosenau terms the 'frontier' between domestic and international policy, is a seamless world of often contested authority in which threats to human security can proliferate (Rosenau 1997: 6, 168). Along this frontier frequently erupt the violent communal conflicts between different ethnic groups which may have various patrons in the wider world of trans-state society. These international linkages often make the domestic conflicts more intransigent and more difficult to reach a solution. The tragedy at Beslan, southern Russia, in which between 400 and 500 people, mostly children, lost their lives as a consequence of a terrorist attack on the local school, is the most recent in a continuing series of such intra-state conflicts with international dimensions where the domestic-foreign divide is transparent. ${ }^{1}$ 
Since the formal end of the Cold War in 1989, civilians have been the main victims of these many violent intra-state conflicts - Kosovo, Rwanda, Bosnia, Sierra Leone and, now, Darfur where over a million people have been rendered homeless by 'ethnic cleansing' activities of the pro-government militia, the Janjaweed. ${ }^{2}$ Similar distressing spectacles of human suffering led Lloyd Axworthy, former Canadian Minister for Foreign Affairs and International Trade, to call for formulation of an international policy which privileges the protection of the human being, rather than the state. He advocated a change in the concept of what 'being secure' means and stipulated that 'the language of foreign affairs should include protecting civilians, war-affected children, the threat posed by terrorism, drugtrafficking and forced migration - not just states' rights and national sovereignty'. (McRae and Hubert 2001: 3). As David Dickens has asserted, the Canadian approach focuses on human insecurity arising from violent conflict and non-violent threats (Dickens 2002: 2). In Dickens' view, the Canadian formulation of human security 'entails taking preventive measures to reduce vulnerability and minimize risk, and taking remedial action where prevention fails' (ibid.).

The Canadian approach gives priority to 'freedom from fear' and the concomitant civil and political rights of individuals. It is thus closely aligned with the Western human rights policy agenda. By contrast, the policy of Japan has been to emphasize 'freedom from want' in pursuing a strategy which the Japanese government considers is less confronting for developing societies. In December 1998, in Hanoi, the then Japanese Prime Minister Keizo Obuchi announced in his 'Intellectual Dialogue on Building Asia's Tomorrow' the establishment of a Trust Fund for Human Security to be located in the United Nations Secretariat with an initial funding base of 500 million yen. The objective of the fund is to 'translate the concept of human security into concrete activities by supporting projects... that address ... various threats to human lives, livelihoods and dignity currently facing the international community, including poverty, environmental degradation, conflicts, landmines, refugee problems, illicit drugs and infectious diseases such as HIV/AIDS.' Since then, human security has become a key aspect of Japanese foreign policy.

Initial steps to implement the Japanese policy were taken in September 2000, at the UN Millennium Summit, when Japanese Prime Minister Yoshiro Mori announced the creation of a Commission on Human Security. Its membership includes 12 internationally prominent figures led by co-chairs Sadako Ogata, former United Nations High Commissioner for Refugees, and Nobel Prize winner, Professor Amartya Sen, former Master of Trinity College, Cambridge University. The role of the commission is to make recommendations to the international community on guidelines for concrete action which will translate the concept of human security into action. By the end of June 2002, the Trust Fund for Human Security had provided USD 84 million for 61 projects which included assisting refugees in Kosovo and East Timor. Citing the widening gap between rich and poor nationally and internationally, despite the improvements in the standard of living brought by globalization and liberalization of trade and investment measures, the Japanese Ministry of Foreign Affairs in its explication of the 


\section{Holistic and human security}

human security concept gives priority to the individual human being and human potential. It asserts, 'Each country, as a nation state, is still responsible to its people for ensuring state security and the importance of security and economic policies at the state level has not lessened at all. However, such policies should now be complemented by efforts focused on individuals to ensure human security.' $^{3}$

Consistent with this policy perspective, Japan was amongst the first and most generous (USD 600 million) donors to the international fund to assist victims of the 26 December 2004 tsunami which followed the undersea earthquake off the north-west Sumatra coast. Others have followed suit: on 7 January 2005, at the leaders summit in Jakarta to plan how best to address the human consequences of the disaster, Australian Prime Minister, John Howard, announced an unprecedented AUD 1 billion aid package to Indonesia (The Australian, 7 January 2005, p. 1). Other substantial contributions were made by the World Bank and the governments of Germany, the US, Norway, Britain, Sweden and Canada. In these countries, the private sector contributions both from individual citizens and the corporate sectors were also overwhelmingly generous. By the end of the first week of January 2005, Kofi Annan announced that some USD 5 billion had been pledged to the tsunami assistance fund, demonstrating the global recognition of the sense of mutual responsibility of peoples and governments to address the consequences of this disaster.

Whilst the Japanese approach is more palatable in Asia than the Canadian approach, the crucial interlinkage between freedom from want and freedom from fear in the human security concept has been delineated at great length by Amartya Sen (1999) and Amitav Acharya (2002a) who observes that 'no serious advocate of human security would condone the pursuit of economic and communitarian approaches at the expense of the safety and dignity of individuals and peoples. The tolerance of human rights violations for the sake of economic development or social stability should have no place in the human security paradigm' (Acharya 2002a: 10). Acharya is surely correct in asserting that the two perspectives are complementary. "Pursuing "freedom from want" in the absence of "freedom from fear" is bound to be of limited utility' he argues (Acharya 2000a: 17).

Both the Japanese and the Canadian perspectives are broader than the Norwegian view articulated by Sverre Lodgaard of the Norwegian Institute of International Affairs who defines human insecurity narrowly as 'vulnerability to physical violence during conflict' and excises the notion of threats arising from socio-economic or natural disasters (Acharya 2002a: 8). Lodgaard's view would seem to take scant account of the human tragedies arising from the Asian financial and economic crisis of 1997 and the several subsequent regime changes in South Korea, Thailand, Indonesia and The Philippines which it precipitated. The broader view of human security encompassed by both the Japanese and the Canadian approaches is, as Acharya (2002a: 8) has pointed out, more closely aligned with the Asian comprehensive security agenda discussed in the next section. Summarizing the various interpretations of the human security concept, Acharya is at pains to emphasize that these are mutually reinforcing and 
contribute to making the concept potentially an 'instrument of a just and secure world'. Thus he states,

Human security has been presented variously as a means of reducing the human costs of violent conflict, as a strategy to enable governments to address basic human needs and offset the inequities of globalization, and as a framework for providing social safety nets to people impoverished and marginalized by sudden and severe economic crises.

(Acharya 2002a: 5)

The key question of course is how should the international community react when human security is in jeopardy either from natural disasters or from the actions of the guardians of the nation state?

These are thorny issues. The concept of national sovereignty has been the capstone of international relations since the 1648 Treaty of Westphalia ushered in the era of secular nation states and ended the legitimacy of the concept of sacred universal empire in Western Europe. Extension of the concept of secular nation states to the non-Western world had to await the establishment of the UN and the rollback of colonialism after the Second World War. The pre-eminence of nation states and states' rights since 1945 has been the main theoretical perspective in the various schools of international relations, from realist to neo-realist, liberal and neo-liberal to constructivist. The inviolability of sovereignty and non-interference in the internal affairs of nation states has been strongly upheld by the newly independent states emerging from colonialism. ${ }^{4}$ Along these lines, Hedley Bull (2002) proclaimed that the 'fundamental principle of world politics in the present era is the idea of a society of sovereign states', which he asserted is the 'supreme normative principle of the political organization of mankind'. From this notion of a society of sovereign states, he declared, stem not only the basic rules of coexistence among states and other actors in international society, but also the capacity to 'mobilise compliance with the rules of international society' (Bull 2002: 134). It is a perspective which also finds its place in the work of James Mayall who emphasizes that there would appear to be no viable alternatives. He writes,

[There is] no immediate prospect of transcending the national idea, either as the principle of legitimization, or as the basis of political organization for the modern state. For the time being, international society cannot develop in ways which are inconsistent with the continued existence of separate national states. Islands of supra-national sovereignty may arise here and there, but the principle of popular sovereignty will not easily translate into supra-nationalism.

The original conception of international society has survived into the modern world with its basic structure intact. It is a conception of a society of states which recognize each other's sovereignty, engage in regular diplomatic relations with one another and uphold international law. The theoretical alternatives to this scheme have not materialized.

(Mayall 1990: 145) 


\section{Holistic and human security}

The concept of the sovereign state, however, has been under challenge both from transnationalists who assert that the exigencies of the market are making the territorially bounded sovereign state obsolete (e.g. Ohmae 1995: 5, 12-13 ff.; Strange 1996: 5-33) and from reformers who, appalled by the various spectacles of states' violence perpetrated against their own citizens, have attempted to reformulate the notion of sovereignty in terms of the nation state's 'responsibility to protect' the citizens and minorities living within its jurisdiction. This term has been given currency by the work of the International Commission on Intervention and State Sovereignty (ICISS) whose report, The Responsibility to Protect, was released in late 2001, after the tragedy of the September 11 terrorist attacks on the World Trade Center, in which around 3,000 citizens from 80 countries lost their lives.

The proper exercise of sovereignty by any nation state, the ICISS proposes, is the responsibility to protect its citizens and minorities from avoidable catastrophe. Whilst defending the concept of sovereignty and the nation state's conventional monopoly on the right to wage war in defence of its territorial integrity, the ICISS report proposes a significant modification of the concept consistent with developments in human rights and international law. The concept of sovereignty as the responsibility of the state to protect its citizens from avoidable catastrophe further erodes the domestic-foreign divide, bringing domestic and international policy into alignment in considerations of what constitutes proper governance. In the Commission's view,

The defense of state sovereignty, by even its strongest supporters, does not include any claim of the unlimited power of a state to do what it wants to its own people. The Commission heard no such claim at any stage during our worldwide consultations. It is acknowledged that sovereignty implies a duel responsibility externally - to respect the sovereignty of other states, and internally, to respect the dignity and basic rights of all the people within the state. In international human rights covenants, in U.N. practice, and in state practice itself, sovereignty is now understood as embracing this dual responsibility. Sovereignty as responsibility has become the minimum content of good international citizenship.

(International Commission on Intervention and State Sovereignty 2001: 8)

The Commission's modification of the conventional concept of state sovereignty paves the way for considerations of a framework under which international intervention might be considered, and how it might be implemented in order to protect people when their state either fails, or is unable to do so. This sensitive issue goes to the heart of the concept of human security in practice and takes it out of the realm of idealistic theory. The failures by both the international community and the state, at Srebenica and Rwanda in the 1990s and the Cambodian genocide in the mid-1970s, for example, underpin the need for such a framework, if the human security concept is to be implemented. Such twin 
humanitarian and security considerations led Australia, in 1999, to organize ASEAN support for an international intervention force in East Timor in the wake of the widespread post-referendum violence against the civilian population by pro-Indonesia militia opposed to independence for the new nation. The intervention was undertaken in spite of the anticipated difficulties it would cause in the Indonesia-Australia relationship and only after the international community had applied intense pressure on Jakarta (Goldsworthy 2003: 255). There was a sense that previous failures by the international community to protect vulnerable civilian populations needed to be redressed. ${ }^{5}$ The ICISS report plainly delineates the transnational impact of multiple failures in the responsibility to protect.

Intra-state warfare is often viewed, in the prosperous West, simply as a set of discrete and unrelated crises occurring in distant and unimportant regions. In reality, what is happening is a convulsive process of state fragmentation and state formation that is transforming the international order itself. Moreover, the rich world is deeply implicated in the process. Civil conflicts are fuelled by arms and monetary transfers that originate in the developed world, and their destabilizing effects are felt in the developing world in everything from globally interconnected terrorism to refugee flows, the export of drugs, the spread of infectious disease and organized crime.

These considerations reinforce the Commission's view that human security is indeed indivisible. There is no longer such a thing as a humanitarian catastrophe occurring 'in a faraway country of which we know little.' On 11 Sept 2001 global terrorism, with its roots in complex conflicts in distant lands, struck the US homeland: impregnable lines of continental defense proved an illusion even for the world's most powerful state. At the same time, around 40 per cent of the victims of the World Trade Center attacks were nonAmericans, from some 80 countries. In an interdependent world, in which security depends on a framework of stable sovereign entities, the existence of fragile states, failing states, states who through weakness or ill-will harbour those dangerous to others, or states that can only maintain internal order by means of gross human rights violations, can constitute a risk to people everywhere.

(International Commission on Intervention and State Sovereignty 2001: 5)

There could be no clearer exposition of the seamlessness of Rosenau's domestic-foreign divide, or the transnational implications of the human security discourse. This principle is implicit in the spontaneity with which both ordinary people and the governments of the world's most prosperous nation states have responded to the overwhelming need for assistance acknowledged and requested by both the people and the governments, except India, in the tsunami affected countries. Although India along the Tamil Nadu and Kerala coasts and in the Andaman and Nicobar Islands has been one of the worst affected countries, the Indian government with its 8.7 per cent economic growth in 2003-4 is determined 
to be acknowledged as an economic power able to attend to its own problems. It remains to be seen whether this stance will continue or be modified in view of the scale of the disaster, India's increasingly important role in regional and international security and objective to become a major power. To paraphrase John Donne, if no man is an island, neither can any single country thrive solely on its own resources.

\section{The seven vectors of human insecurity}

In 1994, the UNDP Human Development Report cast the spotlight on the seven vectors it considers constitute the key threats to human security. The report identified these as economic security, food security, health security, environmental security, personal security, community security and political security (UNDP 1994: 25). These are what I call the seven horsemen of the apocalypse - the seven elements which may bring unexpected disaster to the human being and over which the individual may have little direct control. The perception that human security would be enhanced by addressing these sources of insecurity led the UNDP to call for 'a profound transition in thinking - from nuclear security to human security' (UNDP 1994: 22). Feelings of insecurity, it stressed, arise within the patterns of our daily lives 'more than from the dread of a cataclysmic world event' (ibid.). The report defined human security as 'safety from such chronic threats as hunger, disease and repression... it means protection from sudden and hurtful disruptions in the patterns of daily life' (UNDP 1994: 23).

The seven vectors of human insecurity identified earlier encompass two major elements: they include both freedom from want and freedom from fear. Freedom from want subsumes the economic and social aspects of human insecurity; freedom from fear, the political and civil aspects. These have been foremost in the UN's formulations of international law, covenants and protocols since its inception; however, owing to the ideological divide during the Cold War the concepts of freedom from want and freedom from fear became dispersed into separate entities as reflected in the 1966 Covenants on Economic, Social and Cultural Rights and on Civil and Political Rights, with one side in that era privileging freedom from want - the Covenant on Economic, Social and Cultural Rights - and the other side privileging freedom from fear - the Covenant on Civil and Political Rights. In 1945, the then US Secretary of State had proclaimed 'only victory on both fronts can assure the world of an enduring peace' (UNDP 1994: 24). This universal note has been heard more often since the 1993 Vienna conference on human rights, particularly in the pronouncements of the former Secretary General of the UN, Boutros Boutros-Ghali, and Mary Robinson, the former UN High Commissioner for Human Rights. ${ }^{6}$ Only since the end of the Cold War, has there been a concerted return to recognizing the indivisibility of both sets of 'freedoms', for both are essential to enhancing human capabilities ${ }^{7}$ and security.

In this report, the UNDP distinguishes human security from human development which it sees as a 'broader concept'. Whilst human development is considered to 
be a 'process' of expanding the choices available to human beings - thus enhancing their capabilities - human security provides a policy framework in which to 'exercise these choices safely and freely' (UNDP 1994: 24). The nexus between the two concepts, human security and human development, is obvious: war and insecurity entrench underdevelopment, inhibit human development and heighten the impact of the seven vectors of human insecurity. Whilst the human security concept has been criticized as being too encompassing to be practicable and too awkward to be implemented, its contribution lies in its people-centred focus and the emphasis it brings to our consciousness that security cannot be achieved or maintained through military arms alone. The two sides of human security - freedom from want and freedom from fear-impel us to re-examine the concept of security and an appropriate policy framework for its realization, in holistic terms. The UNDP 1994 report asserts,

The concept of human security stresses that people should be able to take care of themselves: all people should have the opportunity to meet their most essential needs and to earn their own living. This will set them free and help ensure that they can make a full contribution to development - their own development and that of their communities, their countries and the world. Human security is a critical ingredient of participatory development. Human security is therefore not a defensive concept - the way territorial or military security is. Instead, human security is an integrative concept... It cannot be brought about through force, with armies standing against armies. It can happen only if we agree that development must involve all people.

(UNDP 1994: 24)

The human security concept thus necessarily entails redefining the concept of state sovereignty and the moral purpose of the state. The modern nation state is perceived to exist for the benefit of the people, to serve the people in providing public goods and services and to protect them against unexpected disaster. The people do not exist for the benefit of an inchoate state, dictator or ruler. Unlike former formulations of the sovereign state, which had pretensions to 'ownership' of their citizens, the modern nation state is held accountable, through the system of contractual international law underpinning modern international society, for the well-being of its citizens. In democratic governance, sovereignty resides in the people not in the state. Commenting on this different social ontology which marks the modern nation state from its conceptual predecessors, Chris Reus-Smit argues that the 'moral purpose of the modern state lies in the augmentation of the individual's purposes and potentialities, cultivation of a social, economic and political order that enables individuals to engage in the self-directed pursuit of their "interests", (Reus-Smit 1999: 152). This transformation in the concept of sovereignty and what constitutes rightful state action, he perceives to have given rise to a 'new set of basic institutional practices' (Reus-Smit 1999: 163). His approach represents a marked divergence from that of Hedley Bull and leads to 
considerations of what the international community should do, if a state is perceived to engage in action which infringes the notion of 'rightful state action'that is, when is international intervention justified in the name of protecting people, when their state has manifestly failed in its obligations to do so? When is intervention justified, indeed required, to put in place the institutions to enhance human security? The Canadian sponsored report by the ICISS sought to provide answers to these questions with its proposed principles and framework for justifiable international intervention, including non-military intervention and targeted economic, diplomatic and travel sanctions. It states,

The current debate about intervention for human protection purposes takes place in a historical, political and legal context of evolving international standards of conduct for states and individuals, including the development of new and stronger norms and mechanisms for the protection of human rights. Human rights have now become a mainstream part of international relations law, and respect for human rights a central subject and responsibility of international relations.

(International Commission on Intervention and State Sovereignty 2001: 6)

The ICISS report responds to the views of civil society and humanitarian aid agencies that the concept of 'humanitarian intervention' should not be 'securitized' or 'militarized'. It therefore applies the notion of 'intervention for human protection purposes' (ICISS 2001: 9) to the principles and framework it proposes to guide international action when human security has been impugned by the government of the sovereign state itself. In view of the overwhelming failures of the international community at Srebrenica, Rwanda and in Cambodia, the report proposes that the international community no longer has an option of 'doing nothing'; the 'responsibility to protect' applies to both national governments and the international community. The report defines the term 'intervention for human protection purposes' as

[A]ction taken against a state or its leaders, without its or their consent, for purposes which are claimed to be humanitarian or protective. By far the most controversial form of such intervention is military... But we are also very much concerned with alternatives to military action, including all forms of preventive measures, and coercive intervention measures - sanctions and criminal prosecutions - falling short of military intervention. Such coercive measures are discussed in this report in two contexts: their threatened use as a preventive measure, designed to avoid the need for military intervention arising; and their actual use as a reactive measure, but as an alternative to military force. ${ }^{8}$ and State Sovereignty 2001: 9) 
The principles and framework which may guide international intervention, according to the ICISS, emerge from four basic objectives. They are:

- to establish clearer rules, procedures and criteria for determining whether, when and how to intervene;

- to establish the legitimacy of military intervention when necessary and after all other approaches have failed;

- to ensure that military intervention, when it occurs, is carried out only for the purposes proposed, is effective, and is undertaken with proper concern to minimize the human costs and institutional damage that will result; and

- to help eliminate, where possible, the causes of conflict while enhancing the prospects for durable and sustainable peace.

(International Commission on Intervention and State Sovereignty 2001: 11)

These objectives highlight the concern evident throughout the ICISS report that military intervention can do more harm than good, can exacerbate underlying causes of ethnic conflict, can give primacy to the international linkages of domestic opposition groups without improving the quality of life of the people and can have heavy human costs in the indirect casualties of military intervention. The report suggests that alternative means of resolving the causes of intra-state conflict and sustaining any resultant peace settlement are preferable to military intervention.

The title of the ICISS report, The Responsibility to Protect, refers to both the domestic policies of sovereign states in relation to their citizens, and to international society which, it is suggested, has concomitant responsibilities to prevent human crises occurring through activation of early-warning measures; to react with measures which in the first instance do not include military action and to enact measures to re-build conflict-torn societies through appropriate development policies involving a mix of economic, social and political measures. The report's preference for non-military intervention is noteworthy, given the ongoing spectacle of the turmoil in Iraq resulting from full-scale, unilateral invasion of a sovereign state by a 'coalition of the willing', resulting, arguably in less, rather than more, security for the average citizen of that war-torn country, caught in the cross-hairs of what is so recognizably a civil war.

At the same time as it proposes these principles and framework for intervention when human security has been seriously jeopardized, the ICISS report yet upholds the basic principle of international society, that of non-interference in the internal affairs of a sovereign state, lest intervention do 'more harm than good, especially to civilian populations' (ICISS 2001: 29). Citing this 'principle of nonintervention' as the 'norm from which any departure has to be justified', the ICISS draws attention to the dire consequences of ill-considered interventions.

The norm of non-intervention is the equivalent in international affairs of the Hippocratic principle - first do no harm. Intervention in the domestic affairs of states is often harmful. It can destabilize the order of states, while fanning 
ethnic or civil strife. When internal forces seeking to oppose a state believe that they can generate outside support by mounting campaigns of violence, the internal order of all states is potentially compromised. The rule against intervention in internal affairs encourages states to solve their own internal problems and prevent these from spilling over into a threat to international peace and security.

(International Commission on Intervention and State Sovereignty 2001: 31)

Whilst the ICISS acknowledges that military intervention is sometimes unavoidable when state collapse leads to such wholesale civil violence and repression, massacre, genocide, or ethnic cleansing that it 'shocks the conscience' of the international community 'or which present [s] such a clear and present danger to international security, that [it] require[s] coercive military intervention' (ICISS 2001: 32) to redress, yet the ICISS emphasizes that

Most internal political or civil disagreements, even conflicts, within states do not require coercive intervention by external powers. The non-interference rule not only protects states and governments: it also protects peoples and cultures, enabling societies to maintain the religious, ethnic, and civilizational differences that they cherish.

(International Commission on Intervention and State Sovereignty 2001: 31)

Given that the concept of international society rests on an international order of sovereign, interdependent states cooperating with each other, the ICISS upholds the norm of non-interference as a general principle underpinning relations between states. Except under the extreme circumstances alluded to above, the ICISS avers that the interests of all members of the UN, 'are best served if all states, large and small, abstain from intervening or interfering in the domestic affairs of other states' (ICISS 2001: 31).

It is a position espoused also by Genee M. Lyons and James Mayall, whose work highlights the interactions between the individual and the group, and the impact of multiple identities within minorities whose ethnic and political linkages may predispose them to severe human rights violations from the guardians of the nation state. International laws setting out human rights protections must extend to groups as well as individuals; yet intervention by the international community to protect such groups, Lyons and Mayall acknowledge, is fraught with difficulties, even though it is these areas of contested authority which, historically, have spawned the violent civil conflicts of the post-Cold War era (Lyons and Mayall 2003: 210). 'Recent violations of rights... have resulted from the individual's identity with a group, be it ethnic or religious, an indigenous people or as women' Lyons and Mayall assert. The formulation should also include 'children' in the wake of the tragedy at Beslan, where the terrorists obviously did not accede to the UN conventions protecting the rights of the child, and where children 
were 'targeted with intent'. Lyons and Mayall ask the question, 'How can the international community respond effectively to violations of group rights, especially in cases of divided societies where governments have failed and political leaders have authorized violations as a matter of official policy?' (Lyons and Mayall 2003: 200). It is in such societies which have failed to implement pluralist policies protecting minority group rights that severe inter-ethnic violence has flared. As Woosang Kim (2002) has convincingly argued, the human rights of minorities may be 'insecure even in democratic societies' for the apparent adoption of democratic institutions in a society or polity 'does not automatically guarantee the human rights of minorities'. There needs to be an appropriate institutional and legal framework underpinning minority rights (Kim 2002: 49). The social, cultural and political exclusion experienced by minorities and indigenous peoples whose well-being is jeopardized by adverse circumstances often leads to such deprivation, destitution and hopelessness that conflict is inevitable, with consequential implications for transnational security. As Lyons and Mayall argue

The failure to meet pluralist aspirations not only threatens the stability of domestic society, but also calls into question the solidarity of international society, first through its impact on the immediate region and then more broadly through the processes of contemporary globalization.

(Lyons and Mayall 2003: 211)

Protection of human rights issues goes to the heart of the human security discourse. How can freedom from want and freedom from fear be restored in divided societies without exacerbating an already fragile human security situation? In the post-Cold War era, Lyons and Mayall have identified the two most serious challenges to the UN's human rights regime - group identity as a source of civil conflict and the proper role of the international community in the face of gross human rights abuses which create extreme humanitarian emergencies (Lyons and Mayall 2003: 209). It is this nexus of issues which the ICISS has presented as the international community's 'responsibility to react' so that gross human rights violations cease; and the 'responsibility to rebuild' in the event that international intervention - military or non-military - should be effected. Rebuilding the economic, social and political institutions becomes essential to sustaining the peace in post-conflict societies so that freedom from want and freedom from fear can be realized. Effective conflict prevention, peacemaking and peacebuilding strategies require the promotion and protection of human rights - economic, social and cultural as well as civil and political - if the seven vectors of human insecurity are to be held in check, for 'peace that is not accompanied by strategies for the promotion and protection of human rights is unlikely to be a lasting peace' (Ramcharan 2002: 5). A central plank in this policy approach is alleviating poverty and putting in place socially inclusive policies which will redress marginalization of dispossessed, disadvantaged groups. Ramcharan argues, 'The assault on poverty is an integral part of the quest for dignity, equality, respect, and 


\section{Holistic and human security}

decent life-chances in the world. The world beyond September 11th must pursue a determined assault on poverty. Global security would simply not be possible in a world of increasing poverty' (Ramcharan 2002: 3).

For more than 50 years, it has been a fundamental plank of Western, liberal political theory that human rights are better protected in prosperous, pluralistic, democratic societies where minorities have equal access to the protections and opportunities under law as other groups in the society. Both assimilationist (the US approach) and multicultural (the western European approach) policy frameworks have evolved to guarantee such rights and to seek to minimize inter-ethnic group conflict. Economic and social opportunities supporting civil and political rights in pluralistic societies promote the theoretical position that achievement of the freedoms unleashes the creative capacity of the individual, which in turn enhances his potential to contribute to the well-being of the larger group. Conversely, human potential is inhibited where the freedoms are lacking as in controlled economies or in societies beset by corruption and political oppression. Such impoverished societies - impoverished both in economic terms and in the lack of opportunity for human beings to realize their potential - are generally characterized by widespread abuses of human rights, economic, social and cultural as well as civil and political. The nexus between improved protection of human rights and poverty alleviation in all its dimensions imbues the public policy agenda of 'good governance' delineated by Sen (1999), the World Bank (2002), UNDP (2002) and a host of other writers. Indeed, the horizontal dispersion of comparative affluence has been identified as the crucial factor in establishing viable frameworks for the protection and respect of human rights (Land and Ersson 2000: 280-5). Protection of human rights is considered integral to good governance and central to human security (Ramcharan 2002: 81). In developing, impoverished countries such as Myanmar (Burma) with an unenviable, international reputation for gross violations of human rights against all sectors of its citizens, seeking to repair the ravages of decades of civil and ethnic conflict, the UN Special Rapporteur on Human Rights has outlined the path to improved governance.

Once prima facie evidence has been established that violations of human rights have occurred, the government has the burden to disprove the allegations or to show that it has taken, is taking, or intends to take measures to guarantee respect for human rights and fundamental freedoms.

(Ramcharan 2002: 89)

This is the fundamental responsibility of the state: the 'responsibility to protect'. However, the logic of the protection of human rights being at the heart of human security, has led to questions being raised, whether in the changing relations between states since the terrorist attacks on the US on September 11, 2001, human security is not once again being submerged in a security agenda which privileges the state. Brunnee and Toope raise the spectre of international human rights protections being ignored, subverted, and over-ridden by the major powers' political imperatives to shore up their all too obvious vulnerability to the 
attacks of the dispossessed and the disenchanted. The doctrine of the right to pre-emptive strike, enunciated by the US and now by Russia, has the capacity to destroy the principles on which international society has operated since 1945, the notion of a society of equal, independent sovereign states, observing the norm of non-interference in the internal affairs of other states. Brunnee and Toope write,

Around the globe, the debate over response to global terrorism has raised hard issues concerning the interplay of security concerns, human rights, democratic governance and the use of force. Within the US, influential voices are articulating a merging of these concerns in a way that fundamentally challenges the concepts of state sovereignty, non-intervention and political independence. Fear seems to be the driving force for normative change. This fear is accentuated by the now-recognized vulnerability of modern society... All values are becoming subsumed within the value of security, justifying the use of force against other states in an everbroadening set of circumstances.

(Brunnee and Toope 2004: 248)

The 'human' seems to have been lost; and only a perverted concept of 'security' remains, again privileging major states with the capacity to launch inter-state aggression against weaker opponents. The propensity for allegedly democratic states to blatantly subvert their own human rights norms when implementing the doctrine of pre-emptive strike as a defensive measure against trans-state terrorism has become a component of the post-September 11, state-privileging security agenda. This new formula appears to relegate humanitarian responsibilities to second place, sets aside the norms of international justice and disregards the Geneva Conventions in the pursuit of revenge. In the US, the second Bush administration's (2001-6) cynical policy of 'rendering' prisoners (at least some of whom may be innocent) to other states for the express purpose of being tortured, not only diminishes the international stature of that beacon of democracy, but also jeopardizes the entire human rights framework enshrined in international law. As Ramesh Thakur (2005), senior vice rector of the United Nations University, has observed, the Manichean international foreign policies pursued since September 11 are suborning the very values for which democracies stand. 'We must not', Thakur states, 'privilege security and order to such an extent as to destroy our most cherished values of liberty and justice in the search for an unattainable absolute security.' Abrogating civil rights leads to the type of shocking extrajudicial executions of innocent citizens such as Jean Charles de Menezes, the young Brazilian shot seven times in the head by British police in a tragic case of mistaken identity. No matter what the provocation, as Thakur (2005) states, 'No government has a licence to kill.' Suborning these principles of civil rights in the name of an elusive 'absolute security' places in jeopardy the very framework of international law and domestic justice on which the universal human rights agenda has been based. Brunnee and Toope present this phenomenon of the Western democratic industrialized world actively espousing the strategies and mindsets of the non-democratic polities of yesteryear, whose murderous practices 


\section{Holistic and human security}

the UDHR was intended to circumscribe, as a confronting 'confusion of international legal norms that threatens to undermine constraints on the use of force in international society'. In their view,

This confusion occurs when attempts are made to collapse legally distinct categories such as human rights, refugee protection, and threats to international peace and security into one super-category of threat pre-emption, using the other categories simply as examples of dangers that can be invoked to justify action as defensive, rather than aggressive.

(Brunnee and Toope 2004: 249)

Their discomfort with military intervention, its obvious capacity to be misused to disguise old-fashioned, naked aggression, leads them to call for a reassessment of the human security agenda and particularly the role of Canada, one of the main sponsoring nations for the human security concept. They assert,

The basic premise of that agenda has been that security concerns should be evaluated primarily on the basis of the well-being of people rather than the physical security of states. In the vast majority of cases, the promotion of human security calls not for the resort to military force but for measures that build social and economic capital and improve local governance. In the face of recent developments, Canada must reclaim, and probably recast, the human security agenda. It should also resist arguments for excessive reliance on the use of force. Moreover, caution is warranted where human security arguments are deployed to bolster defensive considerations that do not actually rise to a level justifying the use of armed force under international law.

(Brunnee and Toope 2004: 249)

To intervene or not to intervene, that is the Security Council's dilemma. Under the conditions of global governance it is the Security Council's task to authorize interventions and to stigmatize interventions such as that in Iraq, which proceed without its authorization, as 'illegal'; yet its dilemma whether to do so, or not, and its perceived paralysis of will on various occasions have resulted in a proposed parallel coalition of democratic states which would take on this responsibility when the Security Council fails to act. ${ }^{9}$ Such a coalition is considered 'highly problematic' (Brunnee and Toope 2004: 253), reminiscent of the coalitions of Western powers which stripped imperial China of its sovereignty in the late nineteenth century. Acknowledging that the Security Council's standing may have been impugned by its incapacity to balance its responsibility to restrain the use of force with its responsibility to mobilize forces for human protection, Brunnee and Toope warn that were such a proposal to be implemented it would 'only serve to further poison international relations' without resolving the basic dilemma. 'Developing states' they assert, 'have been fighting for years to destroy the outmoded notion that there is a core group of "civilized states" that provides the sole model to emulate, if a state seeks international credibility' (Brunnee and Toope 2004: 253). Not only does such a coalition evoke the nineteenth-century 
era of 'gunboat diplomacy', but also it raises the spectre of neocolonialism, against which the developing world is constantly on guard. Moreover, in view of some of the actions by the core of so-called civilized states, it is a moot point whether they could still be called 'civilized'.

The ethical issues inherent in the notion of intervention for human protection purposes are thus not easily resolved. In the case of Iraq, the cry of 'oil for blood' is only one amongst many such issues which have beclouded that enterprise. To obviate further undermining of the Security Council, whilst clarifying the framework for intervention for human protection purposes, Brunnee and Toope urge the international community to resist 'a blending of humanitarian and security justifications that could eviscerate the constraints on the unilateral use of force' (Brunnee and Toope 2004: 254). Upholding the norms which have guided international society since the establishment of the UN enhances international solidarity. In Brunnee and Toope's view, norms matter; subverting them puts the whole architecture of international law at risk. They caution, 'States continue to define their relationships with each other through political choices that are influenced by prevailing norms. That is why the promotion of norms matters in international relations' (Brunnee and Toope 2004: 249). If the human is to be put back into security and not overwhelmed by renewed state-privileging doctrines, the human security agenda needs to be implemented and upheld consistent with international norms and human rights law. The paradox is, can this ever be achieved through military force alone or is there a much broader socio-economic agenda necessary to put in place the foundations of a sustained peace in conflict-riven societies, and to bring the formerly excluded, marginalized groups within an inclusive policy agenda which promotes opportunity, participation and empowerment for all citizens regardless of ethnic or group affiliation? The 'greed or grievance' 10 theory of war and civil conflict suggests that sustaining the peace requires a multifaceted, socio-economic and political approach to rebuilding war-torn societies, if, in Kofi Annan's words, the 'pillars of human security' are to be built on firm foundations.

\section{Common, cooperative and comprehensive security in Asia-Pacific perspective}

Security is seen to be integral to sustainable development. At the Second Intellectual Dialogue on Building Asia's Tomorrow (1999) Pamela J. Noda and her colleagues delineated the crucial linkages between human security, sustainable development and civil society. At this dialogue, keynote speaker, Amartya Sen, emphasized the critical interface between participatory, democratic governance and the capacity for governments to exercise their responsibility to protect their citizens from sudden disasters. With an eye on the precipitate destitution suffered by many vulnerable groups at the onset of the 1997 Asian Financial Crisis, Sen argues,

[I]n ensuring security in the form of avoidance of disaster - whether originating in natural calamities or in policy blunders - democracy and participatory politics have important roles to play... 
The challenge of development includes both the elimination of persistent and endemic deprivation, and the prevention of sudden and severe destitution...the otherwise highly illuminating literature on 'sustainable development' often misses the fact that what people need for their security is not only the sustainability of overall development, but also the need for social protection when people's predicaments diverge and some groups are thrown brutally to the wall while other groups experience nothing like that.

(Sen 1999a: 26-9)

Conscious of the historical predilection of Asian governments to value economic development over participatory politics, Sen dismisses the notion that economic deprivation can be better addressed by authoritarian governments. He states,

That authoritarian regimes are better in fostering economic growth (a claim largely based on selective evidence) has not received any serious general empirical support in extensive intercountry comparisons... success of a market economy is facilitated by a supportive economic environment, rather than by the harshness of the political climate.

(Sen 1999a: 31)

Following Japanese PM Obuchi Keizo at the First Intellectual Dialogue on Building Asia's Tomorrow (1998), Sen takes the position that denial of basic political freedoms and civil rights represents serious human deprivation as much as does economic destitution. Both Obuchi and Sen emphasize the need to take a broad view of security, if human beings are to avoid, what Henry David Thoreau (1854, rpt. 1949) has called, 'lives of quiet desperation', and instead lead 'lives of creativity, without having their survival threatened or their dignity impaired' (Sen 1999a: 31). Human security is seen as a comprehensive approach to dealing with the 'menaces that threaten the survival, daily life, and dignity of human beings and to strengthening the efforts to confront these threats' (ibid.).

The Asian Financial Crisis of 1997 demonstrated conclusively that state and regime security were interlinked with human security. Formerly authoritarian or pseudo-democratic regimes fell from power in Indonesia, Thailand, South Korea and The Philippines amidst the clamours of the vulnerable whose human security had been so fearfully imperilled. Succeeding governments in these countries saw the necessity of moving to implement more transparent systems of democratic governance which would both enhance the political and civil rights of the people and strengthen their economic, social and cultural rights. The crisis demonstrated not only the inextricable linkage between freedom from want and freedom from fear, but also that state and regime security were dependent on human security, a concept, which, as Pranee Thiparat has stated, 'has emerged as a major area of debate within ASEAN' (Thiparat 2001: 1). ASEAN, she asserts, 'has to adopt a new policy direction that is more people-centred' (ibid.) and less state-centric. 
The reform programmes in these countries which followed the 1997 financial crisis highlighted the long road some Asian governments have travelled since 1945 when national security was seen solely in state-centric terms. In the developing countries of Asia, the three dominant paradigms privileging the state security policies of the newly independent countries after the Second World War - common, cooperative and comprehensive security - all looked to economic security as the legitimating credentials of government. In the Asian region, the economics-politics-security nexus, as Harris and Mack (1997) have shown, has underpinned the security practice of most governments both during the Cold War and since its demise. These paradigms have all asked: security for whom and against what? Security of the state or regime has been paramount and national resources have therefore been marshalled against threats to the state or regime arising from ethnic and communist insurgencies and internal instability. Security policy has been built around protecting the core values of the state rather than the individual; and insecurity has been perceived to arise primarily from domestic, internal challenges to political and social order rather than from external threats. A prime source of domestic insecurity was endemic poverty; hence the prominence accorded to economic development by post-colonial, mostly authoritarian Asian regimes that feared internal instability even more than external aggression initiated either by their neighbours or by one of the major powers. Until comparatively recently, the Asian view of security - in both realist and liberal paradigms - has been state-centric, inward-looking, focussed on ethnic and communist insurgency, subversion and suppression of political dissent (Acharya 2002: 72), characterized by a predominant focus on state sovereignty and non-intervention, and in which promotion and protection of human rights and democratic governance have not been the key legitimating principles of government. In 2001, Thiparat called for ASEAN to include 'more forces from civil society such as NGOs, educational institutions, think tanks, foundations, into the process of reformulating its security policy' (Thiparat 2001: 3).

In recent years, ASEAN's approach to security has been reviewed and modified, in line with the realization that economic development alone cannot sustain state or regime security. As Rizmal Sukma acknowledges, ASEAN has come to query whether it needed to choose between human security and political and economic stability, or whether each was a function of the other. Sukma states,

While it might be presumptuous to argue that the emphasis on human security will automatically ensure political and economic stability, one can make a reasonably strong claim that ignoring it will definitely serve as a recipe for disaster.

(Sukma 2001: 62)

Since the 1997 financial crisis, a more holistic approach has been signalled among ASEAN states, which gives greater prominence to the democratic governance and human rights issues integral to human security, and the need to be seen to act as responsible international citizens. The human deprivation and insecurity generated by the financial crisis had such severe impacts on regime, 
national and regional security, that it engendered new policy directions. Sukma points out that the crisis demonstrated conclusively to ASEAN governments that 'when human security was ignored, the people would challenge the state' (Sukma 2001: 64). Recent conflicts between the Muslim and Buddhist communities in Southern Thailand also support this view. The growing strength of civil society in Thailand may be gauged by the pressure exerted on Prime Minister Thaksin Shinawatra to properly investigate the violence against Muslims in Narathiwat province in late 2004 when at least 80 people died in horrific circumstances at the hands of Thai security forces. It is clear that the absence of political security, especially human rights, can itself pose a threat to overall political and economic stability (Sukma 2001: 65).

On the international scene, participation in the 'War on Terror' has yoked together the twin poles of this redefined moral responsibility of the state. Seeking to formulate their own responses to these demands, consistent with their individual views on national or regime security, Asia-Pacific states appear to have evoked aspects of the common security paradigm of the late Cold War era. First articulated by the 1982 Palme Commission, common security emphasized the responsibility of international society to manage the global commons in the interests of joint survival, rather than to continue to operate conflictually in a 'them' or 'us' mode. The end of the Cold War in 1989 and the onset of the War on Terror in 2001 have given new meaning to common security's dictum that the "legitimate security interests of "them" as well as "us" be acknowledged' (Thakur 1997: 67-8). The commitment to joint survival inherent in common security has taken on renewed significance in the context of the rising incidence of global terrorism. Whilst originating in the need to limit the arms race, common security's principle of achieving security with, rather than against others, has led to new security initiatives in the Asia-Pacific region, particularly with regard to the People's Republic of China (PRC) and possibly North Korea, although the solution to this problem is still emerging, which, as Alan Dupont (ABC radio interview, 13 November 2004) has articulated, could well be bound up with the problematic security relationship between Japan and the PRC. For the moment, the US needs the cooperation of both the PRC and Japan in the War on Terror. Ultimately it will need to underpin long-term accommodation between the moderate Muslim world and international society, if the War on Terror is to have closure, as did the Cold War. In seeking to come to grips with these new demands on concepts of national, state or regime security, some Asia-Pacific governments are moving away from state-led economic development as the legitimating principle towards a new accommodation between the principles of human security and state security. This new accommodation may be termed 'holistic security' and will be discussed more fully in the following section. Suffice it to draw the congruence at this point between human security and political and economic stability. For Sukma,

Human security serves as a pre-requisite for the attainment of sustainable political and economic stability. And political and economic stability serve as an important condition within which human security can be attained.

(Sukma 2001: 55) 
The two organizations devoted to enhancing regional security in the Asia-Pacific, the Association of Southeast Asian Nations (ASEAN - established 1967) and the ASEAN Regional Forum (ARF - established 1993) have both attempted to formulate new approaches to Asian security policy suited to the post-Cold War era. These concepts, comprehensive and cooperative security, remain state-centric. Comprehensive security, a term derived from the Brundtland Commission report, has the advantage of giving prominence to the non-military aspects of security. It recognizes the potential threats arising from environmental degradation, population pressures, limited water resources, health crises and state collapse. As announced at the second meeting of the ARF in 1995, comprehensive security was defined by the Council for Security Cooperation in the Asia-Pacific (CSCAP) as 'the pursuit of sustainable security in all fields (personal, political, economic, social, cultural, military and environmental) in both the domestic and external spheres, through cooperative means' (Tan and Cossa 2001: 32).

At first sight, comprehensive security appears to reflect the seven key elements of the UNDP's human security agenda designed to achieve both freedom from want and freedom from fear. However, as the ASEAN-Institute for Strategic International Studies (ISIS) fifth memorandum sets out, comprehensive security appears to be a re-packaging of the common security policies of the late-Cold War era, with the additional ingredient of what is designated 'national and regional resilience'. Comprehensive security is said to promote 'balanced national development through endeavours in every aspect of life: ideological, political, economic, social, cultural and military' (ibid.). While the concept does reflect the securitydevelopment nexus, its objective - to strengthen 'national and regional resilience' revives the state-led national security formulae of the Cold War era and ASEAN's anti-Communist predecessor, Southeast Asia Treaty Organization (SEATO).

In the view of Tan and Cossa, 'national and regional resilience' is 'an inwardlooking concept aimed at developing a so-called resistance capability against external pressures and internal subversion in a holistic way' (Tan and Cossa 2001: 32). It does not move Asian security policy towards the human security agenda. Each state is encouraged to pursue its own national interests and militarization as a contribution to 'regional resilience'. This concept is designed to enhance regional autonomy, whilst inhibiting the potential for unwanted intervention in regional affairs by the major powers, but at the same time maintaining the advantage of the American security umbrella to prevent the emergence of a regional hegemon. ${ }^{11}$ The interactions of the 10-member ASEAN and the 23-member ARF are perceived to be moving towards a recognizable 'security community', but not a 'defense community' (Acharya 1998: 218). Multilateral dialogue, norm sharing and confidence-building exercises through both Track II (senior official level) and Track III (civil society/non-state actors) processes reinforce the understandings of the long-established bilateral treaty mechanisms between individual members of both ASEAN and the ARF, and institutionalize the expectations that differences will be resolved peacefully in accordance with the 'ASEAN Way', without recourse to the formal conflict resolution mechanisms of the European CSCE/OSCE. ${ }^{12}$ 
The sister concept of cooperative security, proposed as a possible policy platform for the ARF by former Australian Foreign Minister, Gareth Evans (also co-editor of the ICISS report discussed earlier) has the advantage of encouraging multilateralism over bilateralism, and favouring dialogue on a multilateral basis which can contribute to the development of the norms and values at the heart of the constructivist approach to international relations. Non-military solutions are preferred to military ones; it is inclusive rather than exclusive with regards to both membership and issues to be discussed and while states are recognized as being the main parties, non-state actors are also recognized as significant players who may be part of both the problem and the solution. Tan and Cossa point out that the notion of a communal understanding of power embodied in the concept of cooperative security allows it to incorporate elements of common, collective and comprehensive security reflecting both the 'realist' and 'liberal' perspectives - the notion of a cooperative balance of power maintained through solidarity and reciprocity principles espoused by Metternich; and the value of multilateral dialogue favoured by Castlereagh (Tan and Cossa 2001: 33). It has been said that the concept of cooperative security is a process for managing security, whilst comprehensive security provides the substance for what is to be protected (Caballero-Anthony 2001: 28). The limitations of cooperative security are identified by Ramesh Thakur.

Cooperative security seems to be a remarkably similar beast to collective security. Does it really take us substantially ahead of the U.N. Charter? The limitations to operationalizing a cooperative security system are also very similar to the shortcomings of the U.N. system. Cooperative security does not avoid the contradictions and dilemmas inherent in a system of collective security. In the real world, cases of aggression and genocide are rarely clearcut. Ambiguities would destroy cooperative security just as surely as they thwart collective security. Alternatively, if all the Charter principles were to be operationalized, then would not a cooperative security system be in place?

(Thakur 1997: 69)

Thakur thus finds both cooperative security and the earlier Cold War concept of collective security unable to achieve their stated aims. He notes that the intrinsic tension in the collective security concept caused by the veto clause (Article 27.3 of the UN Charter) means that in practice only the major powers can threaten international peace. Since, in his view, war between smaller powers cannot of itself jeopardize world peace, collective security does not apply to small states; and since it is not enforceable against the major powers owing to the veto capacity of the permanent members of the Security Council, collective security is impossible to operationalize (Thakur 1997: 69-70). What he has labelled the 'extensive decision-blocking competence of the permanent members' (ibid.) has in effect had the anomalous consequence of the unilateral US-led aggression by a major power against Iraq, a much smaller power - what might be interpreted as the pre-UN situation in the relations between states. ${ }^{13}$ 
In comparison to cooperative security, comprehensive security may be seen as a peculiarly Asian formulation of security which is given expression through ASEAN norms of regional and national resilience, consensus, consultation and collective decision making and non-interference in the domestic affairs of member states. Asian security practice, as Harris and Mack argue, straddles both the realist and liberal camps. 'All regional states' they believe 'pursue security policies which embrace both liberal and realist assumptions and prescriptions' (Harris and Mack 1997: 27). Whilst pursuing confidence-building measures and developing norms which presuppose peaceful resolution to potential conflicts, they simultaneously pursue bilateral alliances with the intention of inhibiting the emergence of any regional hegemon. The relations of South-East Asian states with North-East Asia, particularly China and Japan, and with the US are pursued within a mix of political and economic policies aimed at maintaining a balance of power among potential regional hegemons.

Amitav Acharya has argued that whilst ASEAN has enjoyed the indirect support of the major Western powers and has provided a framework for broad regional security cooperation despite its eschewing of a formal military alliance among members in favour of long-established bilateral ties which pre-date ASEAN, in practice ASEAN has sought to inhibit the scope for great power intervention in regional security matters (Acharya 2002: 1). However, ASEAN's avowed support for regional identity and autonomy have been severely tested, first by the Cambodian settlement, then by the 1999 East Timor intervention and intermittently by crises arising from Myanmar's membership since joining ASEAN in 1997. ASEAN has, however, recently upheld the principles of regional cooperation and solidarity in insisting, successfully, that Myanmar participate in the Asia-Europe Meeting (ASEM) meeting held in Hanoi on 7-9 October 2004. The argument here presented has been that if ASEAN is to agree to the 10 new members of the EU participating, then the EU must accede to all 10 ASEAN members participating similarly in the meeting. Since 1997, the new security policy which ASEAN has pursued through its economic agenda - as expressed in the moves to establish a viable ASEAN Free Trade Area - and its political agenda, including extensive use of Track II dialogues in regional security issues, is transforming it from being an inward-looking subregional grouping to one which is proactively developing strategic economic and political linkages able to sustain its regional position in future. ${ }^{14}$ Nevertheless, amongst the original six members of ASEAN (Thailand, Singapore, The Philippines, Indonesia, Malaysia and Brunei) it is doubtful any would wish to be without the additional insurance of their US alliance, particularly in view of the uncertainties associated with the rise of China's power and prestige in the region; and the reshaping of the US-Japan alliance to enable Japan to take a more active military role in regional security affairs, a controversial development which does not sit well either with major sections of Japan's population, or with its neighbours, especially China, who have bitter memories of Japan's aggression before and during the Second World War. As John Chipman asserts, 'Regional emperors who shed their links with external powers which play a balancing role will find in their regional relations that they have no clothes' (Chipman 1997: 29). 


\section{Holistic and human security}

\section{Holistic security - definition and practice}

In this context, the answer to the question of 'Whose security?' is being protected by the comprehensive security agenda would clearly favour regime and state security ahead of human security. Yet Thakur's observation that security policy appears to be developing along parallel lines - one favouring the logic of a national security agenda in accordance with Article 2.7 of the UN Charter which prohibits interference in the domestic affairs of states, and the other, by contrast, urging the responsibility of the international community to intervene when there are gross violations of human rights in any country (Thakur 1997: 67) - obscures the possibility that the two tendencies may in fact intersect. States or regimes chary of their sovereignty and autonomy (as all states are, including the major and middle powers) may seek to reduce the possibility of international intervention on human protection grounds by implementing public policies which enhance human security, and subsequently seeking to be recognized as responsible international citizens. If sustainable development, with its conceptual links to strengthening civil society, is at the heart of the comprehensive security concept in principle (Devitt and Acharya 1996: 3), then state-led policy initiatives which enhance human well-being provide the possibility for transforming the comprehensive security concept into one which may be termed holistic security - the development and application of public policy which privileges human well-being within the context of state resilience, yet acknowledges 'the ongoing centrality that military-related issues play in state and interstate relations' (Devitt and Acharya 1996: 10).

Holistic security takes into account the threats to human and national security arising from endemic poverty, environmental degradation and other transnational issues, yet gives due weight to Denny Roy's argument that economic prosperity in itself does not guarantee peace (Roy 1997: 3); economic interdependence can increase state vulnerability, a perspective developed by Paul Dibb who observes, 'Historically, economic prosperity and growing interdependence have not seen the avoidance of war' (Harris and Mack 1997: 100). Highlighting the interconnections between human, comprehensive and holistic security, Stuart Harris has drawn attention to the liberal thesis which presents economic development as a precursor to political liberalization in authoritarian states, since it creates the resources and conditions for the growth of civil society (Harris and Mack 1997: 60 ), a concept which underpins sustainable development. Holistic security then draws attention to the fact that neither the new security agenda implicit in human security, nor the state-privileging agenda of comprehensive security can, of themselves, achieve their stated aims. Analysing the new security issues, Paul Bracken comments, 'contrasting the traditional and non-traditional security issues is misleading' and has made the military dimension seem 'an outdated type of security except in highly unlikely circumstances' (Bracken 2001: 72). In seeking to correct this imbalance, holistic security gives due weight to both the traditional and the non-traditional security agenda, from the perspective that each complements the other. It recognizes the validity of Bracken's position that it is simplistic to 
simply substitute the 'new' - non-military threats - for the 'old' military-based threats in the traditional security paradigm (Bracken 2001: 74).

Holistic security - the merging of human security and comprehensive security in a framework which privileges human well-being rather than state or regime survival - places a premium on the public policies inherent in the state's responsibility to protect its citizens and minorities, by both non-military and military means. This security concept is foreshadowed in Alan Dupont's incisive and timely volume, East Asia Imperilled (2001). Dupont argues,

Even though the territorially constructed state remains the principal actor in the international system and the standard vehicle for political expression, it ought not to be enshrined as the only legitimate security referent. As advocates of human security argue, more weight should be given to protecting the individual from hunger, thirst, disease and repression since the security of the state has no real meaning if divorced from its human constituents. Human security and national security are threatened in equal measure by transnational phenomena. The forced displacement of people by governments is injurious to the security of those individuals compelled to move. Conversely, the large-scale, unregulated movement of people across borders threatens the sovereignty and internal cohesion of affected states, especially when illegal migrants and refugees are of different ethic or religious backgrounds.

(Dupont 2001: 239)

Noting the changes to the international security agenda to take account of transnational threats such as environmental degradation, unregulated people movements and transnational crime, Dupont cautions that the causal connections between these and inter-state conflict have not been demonstrated adequately in empirical research (Dupont 2001: 11). Tilting towards the holistic security concept he writes,

Human security as a concept is not without its own failings. Its advocates need to explain better... how the concept can be effectively made operational. There may be no clear answer to this particular dilemma because human security is more a statement of principle than a guide for action in areas such as defence and foreign policy. Protecting people from the manifold hurtful disruptions to daily life is a worthy societal goal, but giving meaningful effect to it may be problematic. Nevertheless, the concept of human security underlines the inefficacy of enshrining the state as the exclusive object of security and serves a useful purpose in providing an alternative criterion for evaluating the harmful effects of transnational threats.

(Dupont 2001: 9-10)

Dupont's work helps to redress the imbalance in the new security discourse. Along similar lines, the view has been put forward that the new security agenda, which emphasizes the non-military threats to human and state security, is 


\section{Holistic and human security}

essentially an artificial construct promoted by the technologically advanced major powers to reflect and 'lock in' their advantageous power relationships vis-à-vis the developing world, and thereby control the modernization processes underway in China and other parts of Asia (Bracken 2001: 73-4). Bracken observes that this new security agenda delegitimizes the use of military force, but privileges comparative technological advantage. He states, 'When the West had total military advantage, there was little talk about new non-traditional non-military dimensions of security in Western discourse' (ibid.). In his view, changing the focus of security to include perceived non-military threats is essentially about control of the security discourse which is designed to clarify the fault lines of power relationships among the status quo powers. It does not reflect the underlying reality of the insecurity which plagues the lives of over a billion people in the developing world whose lives are frequently in jeopardy from the military guardians of the state-security apparatus (e.g. Darfur, Myanmar, Zimbabwe). Nevertheless, in some parts of Asia the new security agenda has served to bring about civilian control of the military (as in Thailand and South Korea) and to strengthen the forces of civil society. Holistic security seeks to redress the imbalance in the new security agenda by bringing both non-military and military threats to human security into equilibrium. This perspective recognizes the validity of Sheldon Simon's observation that the 'intertextuability of discourses and texts' create political discourses that do not necessarily correspond to an existing social reality, but to other previously existing discourses and the conventions governing them (Simon 2001: 16). The conventions governing the human security discourse require that the voices of marginalized groups - both in domestic and in international society - be heard; but to give effect to this policy position requires the instrumentality of the state. It is in the marriage of these two perspectives, seeking to identify the state as the servant of the people, that the concept of holistic security may make a substantial contribution. 


\section{The security discourse in Myanmar \\ Regime, state and people}

\section{Introduction}

Since joining ASEAN in July 1997, Myanmar has increasingly pursued an international policy based on winning and influencing regional friends, and enhancing its relationships with China (PRC) and India, as counterweights to Western (US, UK, EU) sanctions and criticism of its human rights record. This move into the international arena has been a distinct modification of the neutralist and isolationist policies pursued during the era of the late General Ne Win, who ruled the country from 1962 to 1988, and indeed of the era of Parliamentary democracy under the late Prime Minister $\mathrm{U} \mathrm{Nu}$, during whose terms of office (1948-58, 1960-2) the country was a founding member of the Non-aligned Movement (NAM) at the Bandung conference in $1955 .{ }^{1}$ It is, however, only a modification, albeit a significant one. In mid-2004, Myanmar's foreign policy was described by a government spokesperson in these terms: 'Since day one, we are everybody's friends; we are nobody's ally' (Hla Min 2004: 149). Being everybody's friends and nobody's ally marks Myanmar's re-integration into the international community, a policy which is likely to continue, whichever military faction is ultimately in charge in Myanmar. Moreover, it is unlikely that Myanmar's military government will revert to the extreme isolationist policies of the Ne Win era. Whatever the outcome of the National Convention, which reconvened 17 February-31 March $2005,{ }^{2}$ the processes of re-integration into the world economy (initiated with the formal dissolution of the legal framework of the socialist economy in 1989-90) and international society are likely to continue, Myanmar style, despite the country's relinquishment in July 2005 of the ASEAN chairmanship which it had been due to take up in 2006.

This stance has underpinned the recent security discourse in Myanmar. With no obvious external threats to the country's cherished sovereignty, not even from the US (which is unlikely to invade Iraq-style despite the urging of some of the Burmese Diaspora), security for the state of Myanmar has been seen primarily as a function of its domestic politics, a response to the civil war and ethnic insurgencies which erupted at independence from Britain in 1948, the Kuomintang (KMT) incursions (1950-61), the activities of political dissidents and pro-democracy activists, the determination of the military regime to cling to power, a fragile 
economy and a socio-economic fabric desperately requiring remedial attention. Decades of unrest, and constant displacement of many of Myanmar's people, have been the people's legacy since the Japanese invasion in early 1942 abruptly ended the British colonial administration which had swallowed up the country in three wars, 1824-6, 1852 and 1885. Myanmar (and its earlier identity as Burma) exemplifies the quintessential facets of human insecurity - political, civil, economic, social and cultural - in all its elements. It is small wonder that the public policies intended to weave together the threads of the security discourse have been expressed in official parlance in terms of stability, peace, unity and development. ${ }^{3}$ Yet the tragedy of modern Myanmar, as many observers and writers have noted, is that the very policies meant to give effect to these watchwords have privileged regime and state security at the expense of human security. The consequence of these policies has been the evolution of a 'strong regime, [but] weak state'. ${ }^{4}$ It is the contention of this book, that the balance in the security discourse in Myanmar needs to be reversed: a strong and stable state is a function of public policies which make human security the pre-eminent focus of government policies as well as provision of goods and services. Not to do so, imperils the very state security which the military regime seeks to protect as justification for its own continuance in power.

On 18 October 2004, Myanmar's regional neighbours in ASEAN and the international community at large received with some concern the news that the reformist Prime Minister, General Khin Nyunt, had been relieved of his duties 'permitted to retire for health reasons' in the terms of the official announcement. He was subsequently reported to have been incarcerated in Myitkyina, in northern Myanmar, reputedly having been sentenced to 44 years jail, with the possibility of execution not ruled out, while his former colleagues were subject to rigorous interrogation in an attempt to obtain information which would implicate him in an alleged plot against the state. The words of Henry VIII's Cardinal Wolsey come to mind as he reflected on his similar calamitous fall from power: fame, Wolsey said, was like floating on a pig's bladder, these manner summers in a sea of glory. The fall of General Khin Nyunt has been similarly precipitous. In mid-2005, negotiations with Senior General Than Shwe and Vice Senior General Maung Aye of the SPDC, resulted in the former prime minister's sentence being commuted to house arrest, a mercy not accorded to many of his followers who endure lengthy jail terms.

The former head of the National Intelligence Bureau for some two decades, and former Secretary-1 of the State Peace and Development Council (SPDC), General Khin Nyunt had received a certain amount of international acclaim, since being elevated to the Prime Ministership in August 2003, for his guiding of the military government's seven-point 'Roadmap to Democracy' and initial reconvening of the National Convention in late 2003 which is charged with drafting the country's new Constitution. It was reported that the Thai Prime Minister, Thaksin Shinawatra, who in early December 2004 was invited by the new Prime Minister, Lt Gen. Soe Win, to pay an official visit to Myanmar, even offered to send a bouquet of flowers to assist General Khin Nyunt 'to recover'. Shortly 
afterwards, Prime Minister Thaksin made a brief trip to Yangon, allegedly to attend the Buddhist Conference and have an opportunity for private talks with Myanmar leaders. The new Indonesian Foreign Minister made a sudden unannounced visit to Yangon to check on the situation himself. Such was the concern that regional economic initiatives, set in train between August 2003 and October 2004 for the express purpose of improving human security, state (and thereby regional) resilience, might be derailed. Prime Minister Thaksin had called these initiatives 'sharing the prosperity', a visionary, strategic policy reminiscent of former Thai Prime Minister Chatchai Choonhavan's policy to 'turn battlefields into marketplaces' which was initiated in the late 1980s to bring the former Indochina countries into a regional economic co-prosperity sphere.

Thailand's 'good neighbour' policy of course reflects its own security interests. It is not to the advantage of any of the 10 ASEAN states that any one of them should collapse; nor is it to the advantage of any that human security in any other ASEAN state should be so imperilled that refugees fleeing civil unrest should flood across porous borders, as has happened in the wake of earlier conflicts in Cambodia, Laos, Vietnam and Myanmar. Regional initiatives which enhance human security in Myanmar by fostering economic development, investing in human resource development and strengthening social cohesion are insurance against state collapse, facilitate sharing intelligence related to the 'War on Terrorism' and make for an improved security environment for all Myanmar's neighbours. ASEAN's 'constructive engagement policy' with Myanmar is thus mutually beneficial and recognizes the political realities of transitional states like Myanmar where incremental enhancement of the key aspects of human security is more practicable and achievable than sudden, dramatic transformations unlikely to be sustainable. Such incremental enhancement is implicit in the Myanmar government's vaunted seven-point Roadmap to Democracy - 'disciplined democracy' in the government's terms - by which is outlined the series of processes the state intends to pursue in its plan to return the country to democratic governance, albeit with strong military involvement and oversight of policy formulation and implementation. ASEAN's 'constructive engagement policy' however, has not been able to achieve any major political concessions or the release from house arrest of Daw Aung San Suu Kyi.

Recognition of the interplay between human, state and regime security was publicly aired at the seminar on 'Understanding Myanmar' held in Yangon, 27-28 January 2004, hosted by the Myanmar Institute of Strategic and International Studies (MISIS). The government's mantra - peace, stability, unity - is articulated in the opening address of the former Prime Minister, General Khin Nyunt, in stating,

I would like to stress that democracy can only be established in an environment of peace and stability. It must take into account the historical background and objective conditions of the country. Democratic change is never easy and cannot be imposed from the outside. What works for one country may not work for another. If the transition to democracy is not built on firm 
foundations and is not accompanied by steps to establish credible institutions, it will result in disintegration of national unity. Like a toddler taking its first steps, we must proceed step by step before larger strides can be taken.

(MISIS 2004: 2)

The nexus between state, regime and human security was expressed in terms of both political and socio-economic development, and efforts to strengthen Myanmar's fragile social cohesion. The former Prime Minister envisaged this nexus as programmes for effective poverty alleviation, sustainable economic growth and eradicating the barriers to enhanced well-being for both the minority groups and the majority Burman population. In expressing appreciation for the support and assistance rendered to Myanmar by regional neighbours, General Khin Nyunt drew attention to initiatives arising from the four-nation (Cambodia, Laos, Thailand and Myanmar) economic cooperation summit held in Bagan in November 2003. These initiatives are designed to generate economic growth, reduce income disparity and alleviate poverty particularly in the border areas where the minority peoples have long been disadvantaged. Referring to the ceasefire agreements with 17 formerly insurgent groups, negotiated since 1989, General Khin Nyunt stated, 'The peace and stability that now reigns in the country is unprecedented and augers well for the future of the country' (MISIS 2004: 4). The advent of these ceasefires has provided the possibility of developmental infrastructure projects, especially in health, education, transportation and communication services, for the peoples of the border areas. Since its establishment in 1992, the Ministry for the Progress of the Border Areas and National Races has put in place such projects in the 18 areas it administers at a reputed cost of around USD 550 million. $^{5}$

Since the northern border areas contiguous with China, Thailand and Laos were first mapped by Sir James George Scott, K.C.I.E., and his Chinese counterparts in the 1890s (an ongoing exercise still in process at the time of the Iselin Commission in 1935 and not finally resolved until the 1950s) these regions have been considered prime sources of insecurity for the state and the various regimes in power in Yangon (Rangoon). Together with the western border regions abutting India and Bangladesh, and the south-eastern littoral adjacent to Thailand, these areas have hosted the numerous insurgent groups which challenged state power and identity and sought to delineate contested spheres of authority utilizing revenues drawn from taxation of local cross-border trade, smuggling and the drug trade. Although all insurgent groups have not yet made peace with the Yangon government - and negotiations with one of the main challengers to state authority, the Karen National Union (KNU) have still not been concluded - it is no mean feat that since 1989 government negotiators have been able to reach agreement with 17 of the 20 formerly insurgent groups, including the Wa, Kokang, Kachin, Mon and $\mathrm{Pa}-\mathrm{O}$. Moreover, the peace negotiations were set in train and successfully concluded without international brokerage. Indeed, at times there have been 
indications of intervention from certain Western states in order to maintain a state of conflict between some of the insurgent groups and the Myanmar government.

It is in these border regions where, during the decades of civil war up to the present, some of the most egregious human rights abuses have been reported. HE Dr Kyaw Win, former Myanmar Ambassador to the UK, made this sensitive topic the focus of his contribution to the MISIS seminar in January 2004. He chose to discuss three key issues, religious toleration, use of child soldiers and forced labour (MISIS 2004: 130-5) together with Myanmar's implementation of the right to development. In refuting Western criticism on these issues, Dr Kyaw Win drew attention instead to Myanmar's achievements in some aspects of social policy: to increased enrolment and literacy rates, extended life expectancy at birth and achievements in primary health care. Whilst there is clearly considerable scope for enhanced civil and political rights, as well as economic, social and cultural rights, Dr Kyaw Win articulated the priority Myanmar had been giving within limited national resources to the improvement of certain aspects of the social fabric. ${ }^{6}$

It has been the possibility of this incremental improvement which has attracted the attention of the formerly insurgent groups and in which some of their leaders decided they wanted to share, so that the benefits of the peace could be extended directly to the minority peoples. After the collapse of the China-supported Communist Party of Burma (CPB) in the northern Wa-Kokang regions in 1989, war-weary groups simply decided that they needed to try alternative strategies for improving human security and well-being, and providing a better future for their children. The major ceasefire groups decided that those strategies lay within the fold of the nation state rather than outside it, and led to their participation in the reconvened National Convention in $2003 .^{7}$ This change of policy within the formerly insurgent groups, and their participation in the National Convention processes, is holding out the possibility of a fundamental transformation of the security discourse within Myanmar, and a change in the relations between regime, state and people.

Officially there are over 135 different ethnic groups in Myanmar, in a population of more than 52 million people. Their future well-being and relations with the nation state will determine the success or otherwise of Myanmar's intermittent progress towards inclusive democratic governance. In the process, they will assist the government in Yangon to move away from the policies which Mary Callahan (2003) has vividly characterized as 'making enemies' of the people by the state, towards a new perception that only when the state serves the people, and the people have no need to fear the state, will the much-desired peace, stability and unity be sustainable. ${ }^{8}$ In the wake of the 18 October 2004 removal from office of General Khin Nyunt and his reform faction, it was queried whether the policies of rapprochement with the minority peoples would be continued, or whether some parts of the Myanmar army (the tatmadaw) would exploit the delicate situation to ensure that the ceasefires broke down. In early 2004 the former Deputy Minister 
for Foreign Affairs, H. E. U Khin Maung Win had reflected on this possibility in the following terms:

Myanmar today is enjoying unprecedented peace and stability. With the return to the legal fold by 17 armed groups the issue of armed insurgency that has plagued the nation since the time of the regaining of independence is almost over. However, it should be remembered that these groups have approximately one hundred thousand people still under arms, since the agreement is to allow them to retain their arms for their own security until the emergence of a new constitution. These groups would not have returned to the legal fold if they were asked to give up their arms. Moreover, it should be mentioned that the agreements were verbal ones like gentlemen's agreement $[s i c]$ and there were no signed documents. The danger is that should there be major differences, the possibility exists for them to take up arms against the Government, thus re-igniting the circle of violence. As such, extreme care must be taken in dealing with these groups.

(MISIS 2004: 9-10)

Although the policy environment has hardened since 18 October 2004, indications are that for the moment, the SPDC will not initiate a change of direction with respect to the ceasefire groups, although in mid-2005 there were reports that the SPDC was now demanding unconditional surrender of arms. The situation, however, is precarious and could again dissolve into open conflict; in late 2004-early 2005 there were reports of clashes between units of the Myanmar army and the Wa in Eastern Shan State occasioned purportedly by demands that the Wa turn in their arms. At the time of the removal from office of the former Prime Minister, General Khin Nyunt, rumours were spread in Yangon that he had intended to stage a coup against the SPDC with the assistance of the Wa armed groups (over 20,000 strong). Such rumours appear to have had no foundation, merely serving as one of the pretexts given for his removal from office. However, in January 2005, reports circulated that a unit of the Chinese People's Liberation Army (PLA) was moving into Wa territory as insurance against further pressure on the Wa by the Myanmar government for these groups (United Wa State Army UWSA) to disarm and move further north back into Chinese territory. The situation is clearly very volatile, and could deteriorate, lapsing back into the violence of the pre-1989 period. The question has been mooted, would the Wa, who speak Chinese as their mother tongue, seek Chinese military support again as in the pre1989 period, against the Myanmar government, perhaps with a view not only to shore up their position, but also to attempt a 'rescue' of the former Prime Minister? Would China, to protect its significant strategic investments in Myanmar and to counter the growing Indian economic cooperation with the SPDC, be prepared to launch on such a perilous path? The potentially dire consequences for Myanmar state and regime security of returning to open conflict with the formerly insurgent groups should give the SPDC cause to pause, before embarking on a policy of subverting the ceasefire arrangements. In the longer 
term, more inclusive policies towards all the minority and ethnic peoples will be required, if the necessary adjustment in the relations between people, state and regime is to be effected.

\section{The collective and the individual}

\section{Human security and the state - well-being or ill-being?}

At first glance, human security appears to give pre-eminence to the well-being of the individual and to reify individual human dignity. It sits comfortably within the main Western human rights agenda as articulated in the UN conventions and international law. However, the human security concept significantly also sets individual well-being within the context of the community in which the individual operates and holds out the possibility of recognition that the well-being of the community in turn has a crucial relationship to that of the individual member. That the well-being of the individual and that of the community are integral to each other is dramatically explored by Carson McCullers (1948, rpt. 1965) in her novel The Member of the Wedding, as she has her leading character, 12-year-old Frankie Addams, repeatedly articulate the phrase, 'They are the we of me.' The wider circle of people surrounding her is the community to which she needs to relate and from which she seeks reassurance of her human worth, dignity and justification for existence. Her well-being is tied up with her inclusion in the wider community, as it is impugned when she is excluded from that community.

This insight into the complex relationship between the individual and the community is at the heart of much theorizing about social theory and political concepts, law and philosophy and the nature of civil society, Asian and Western; it underpins concepts of social exclusion and marginalization. That is, is the individual to be privileged? Or is the collective, the community to which the individual relates, or are they mutually interdependent? The horrific individual suffering caused by 'ethnic cleansing' policies in the Balkans, Rwanda and Darfur in modern times, evocative of those unleashed against the Jews and Moriscos in fifteenth- and sixteenth-century Spain, or the Huguenots in seventeenth-century France, clearly indicate that the individual's well-being is inextricably linked to that of the community with which he is identified. ${ }^{9}$ Protecting the rights of groups, as Lyons and Mayall (2003) argue, has become one of the critical issues of contemporary international law.

The one and the many and the relationship of the individual to the community have been at the heart of explorations of notions of civil society since Aristotle. It forms the core of much early American writing on the nature and obligations of democratic man and, until recently, represented the fundamental fault line between those states who gave pre-eminence to civil and political rights as opposed to those states which privileged economic, social and cultural rights. It has formed the basis of Western sponsored human rights law, and critiques of states judged to be violating that law. It forms the divide between exponents of 
the notion of universal human rights such as Donnelly $(1989,1993)$ and those scholars who have argued for cultural relativity - the 'Asian values' debate - pointing out the shortcomings in Western practice as opposed to theory. It is of course the basis of the notion of 'intervention for human protection purposes' discussed in the previous chapter. A Chinese dissident, recently released from long imprisonment, advised those who doubted the applicability of the concept of universal human rights, to visit a Chinese prison (Schak and Hudson 2003: 114-39). Similar allusions could be made to Myanmar prisons, or indeed, prisons in many Western societies, or to the Guantanamo Bay complex. This is the perspective exemplified in the reports, for example, of Amnesty International, Human Rights Watch and other international non-governmental organizations (INGOs) to bring to light appalling abuses of human rights and dignity such as those at Abu-Ghraib prison in Iraq.

Yet reification of the individual itself can also be destructive and disadvantageous to the wider community, with adverse impact on the social fabric, a discourse which also finds its place in much early American writing about the relationship of the individual to the community, as expressed in the fiction and non-fiction of James Fenimore Cooper. In The American Democrat $(1838,1969)$ Cooper analysed the impact of private interest on public institutions, foreshadowing many of the present anti-corruption discourses.

On the manner in which the publick duties of the private citizen are discharged, in a really free government, depend the results of the institutions. If the citizen is careless of his duties, regardless of his rights, and indifferent to the common weal, it is not difficult to foresee the triumph of abuses, peculation and frauds. The American citizens are possessed of the highest political privileges that can fall to the lot of the body of any community; that of self-government. On the discreet use of this great power, depends the true character of the institutions.

(Fenimore Cooper 1838, 1969: 141)

Cooper has here articulated not just the relationship of the individual to his community, but also the concepts of individual rights versus duties which permeate different approaches to what constitutes 'civil society'. This debate can again be heard in the arguments of civil libertarians opposed to some of the laws being drafted to deal with the threat posed by international terrorism.

These views are particularly pertinent to Myanmar which has been listed as one of the most corrupt societies on Transparency International's anti-corruption index, a product of lack of accountability in public policy, opaque business operations, patron-clientelist relations dominating society and politics, and extensive military involvement in the economy, all of which underscore Cooper's perspective above - the 'triumph of abuses, peculation and frauds' when private interest takes priority over 'publick duties'. The relationship between the individual and the community has been, and will always remain, contested, a plaything of various political perspectives, and differing value systems. Seligman (1992) 
sees these contrasting perspectives at the root of different priorities given to the individual and the community in Eastern and Western European politico-cultural envelopes. In the East, he writes, civil society

[E]vokes a strong communal attribute, that, while apart from the State, is also equally distant from the idea of the autonomous and agentic individual upon which the idea of civil society rests in the West. The very pluralism that so many in the West identify with the idea of civil society rests on an almost Durkheimian idea of the individual as infused with moral and transcendental attributes, which is lacking in the East.

(Seligman 1992: 202)

Whilst decrying the socialist fusion of political and civil society in which the rights of the individual are subsumed to those of the state, a fusion which results in widespread states-sponsored violence against their own citizens, Seligman is also conscious of what he calls 'the problem of liberal-individualist ideology' which he identifies as 'how to constitute a sense of community among and between social actors who are conceived of in terms of autonomous individuals' (Seligman 1992: 204). He sees this as the problem for civil society in contemporary times. The problem of the individual and the collective, he says, is

the problem of uniting individual and social wills - of articulating a model of society that would at the same time represent the autonomy of its individual members - that is, the essence of the problem of civil society.

(Seligman 1992: 131)

As definitions of citizenship replaced the historical preoccupation with theorizing civil society, Seligman re-states the modern problem as that of 'formulating the relation of the individual to the collective in terms other than that of an instrumental reason mediating between exclusive, universalized, and particular individuals' (ibid.). In post-socialist, transitional societies like Myanmar, with weak civil societies and definitions of citizenship which reflect the socialist fusion of political and civil society, the relation of the individual to the collective, the community in which the individual operates, is at the heart of concepts of human security, respect for human rights, and the state's relationship with the wider international community.

Calling into question the universalist Western paradigm of civil society with its overwhelming privileging of individual rights as opposed to community rights, Chris Hann and Dunn (1996: 6) asserts, 'At the end of the day, debates about civil society lead us to a renewed awareness of the fusion of the moral, the social and the political in the constitution of all human communities.' Hann identifies the sense of isolation of many individuals in contemporary Western society and asks, 'Where is "collective identity and security" now?' (ibid.). As does McCullers, the social context of the individual, he argues, is crucially related to the experience of security. ${ }^{10}$ 
This interplay between the individual and the larger community was expressed in terms of both political and religious culture by H. E. U Khin Maung Win, former Deputy Minister for Foreign Affairs, at the MISIS seminar in Yangon in January 2004. His address, 'Myanmar Roadmap to Democracy: the Way Forward' articulated the Myanmar perspective on harmonious social relations arising from a balanced relationship between the individual and the community. He states,

Good society to Myanmar is the equilibrium of atta (individual desire) and para (working for the good of the community). Thus, for Myanmar, democracy is not just conferring basic rights but also obligations and duties to the state.

(MISIS 2004: 7)

Achieving and maintaining that balance between the rights of the individual and the individual's duties to the state, will be the major challenge for Myanmar, if the security discourse is to become centred on the well-being of the people. A concomitant discourse will be the state's duties to the people, if the imbalance in Myanmar social and political culture is to be redressed. Reflecting on the ill-being in Myanmar society during the decades when this discourse has been imbalanced, Seng Raw, an ethnic Kachin and director of the Metta Development Foundation, an indigenous NGO engaged in development of the ethnic minority peoples, provides a snapshot of the major fault lines in Myanmar's social and political culture over the past six decades.

[O]ver the years ethnic minority discontent has continued to grow as the gap in development between the minority states and central Myanmar has widened, despite the interdependence of these areas in terms of resources. This uneven distribution in wealth and power between central Myanmar and the ethnic minority states - as well as inadequate communications and infrastructure - has led both urban and rural minority peoples to side frequently with the armed opposition. During decades of conflict, almost every family among the minority communities had at least one member join an armed opposition group, or suffer imprisonment on suspicion of insurgent connections, or both. As a result, the cause of ethnic rights and justice, which originated as a political struggle, increasingly took on overtones of civil discrimination. These attitudes became more entrenched through fighting and abuses committed during counter-insurgency operations. Society in Myanmar, in turn, became polarized, with mistrust between the minority peoples and majority Burmans becoming a deep-rooted problem.

(Seng Raw 2004: 67-8)

If trust is fundamental to the creation of social capital, Myanmar's emerging civil society sector will have a crucial part to play in redressing the imbalance in the security discourse. Again, let us return to Seng Raw. Whilst not resiling 
from the need to give prominence to individual human dignity and worth, she recognizes the several communities to which the individual may belong; the imperative for humanitarian and infrastructure development aid to be provided to impoverished local communities struggling to find an alternative economy to that of the poppy culture and the anomaly that the international community has failed to acknowledge the significance of the peace processes for the advancement of the ethnic minority peoples. She articulates the basic difference also between Western notions of civil society operating in opposition to the state, and the Asian/Myanmar approach wherein civil society organizations will mostly operate in tandem with the state. In Seng Raw's view,

In any aid and development process, it is essential that local institutions are enhanced rather than undermined by international efforts. This means that contact and mutual understanding must be established with all parties involved in Myanmar's ethnic crisis, including those that have long been in the front-line of the problems affecting the country.

For this to happen effectively, informed and sophisticated approaches will be needed to support sustainable solutions. ... Psychological factors are now in play, with the interests of local farmers [i.e. poppy farmers] frequently pitted against concerns of local authorities, including several of the cease-fire groups. In particular, poor farmers feel that they are often singled out for persecution and blame, while local leaders may, for their part, be reluctant to take action against struggling farmers and communities who were their main supporters during the difficult years of armed conflict.

To address this complex challenge, broad-based engagement will be needed by non-governmental and governmental organizations alike, by community and religious-based groups, as well as ethnic cease-fire parties. All should be sustained if they can work with each other through forwardlooking and well-crafted programs crucial to building civil society.

(Seng Raw 2004: 69-70)

The relations between the one and the many, the individual and the collective are never as simple as they appear in some political paradigms. Where the individual may appear divine or demonic, self-sacrificing or self-aggrandizing, so too may the collective, the community, be nurturing or destructive. Seng Raw's vision encapsulates the varying dimensions of this oft juxtaposed dichotomy. Beyond the binary opposites, she sees the organic relationship required to transform the security discourse to one wherein the people are no longer regarded as enemies of the state.

\section{The individual state of Myanmar and the international community}

Myanmar was to have taken over as chair of ASEAN for 2006-7. However, at the summit in Vientiane on 26 July 2005 Myanmar Foreign Minister, U Nyan Win informed the meeting that Myanmar would defer its turn to chair the association. 
The decision was hailed as a victory for the country's Western opponents who had brought pressure to bear: institute democratic reforms and release Daw Aung San Suu Kyi, or suffer the embarrassment of having Washington, London and the EU boycott ASEAN during Myanmar's chairmanship. However, amongst other Myanmar watchers, the decision from Yangon seemed to reflect more a decision to press ahead with the government's own priorities, and coping with the unnecessary aggravations involved in chairing ASEAN was something the SPDC decided it could do without. The Senior General is known not to be entranced with international organizations and in the weeks preceding announcement of Yangon's decision, there were moves afoot suggesting that the government was about to expel international NGOs from the country and rescind its membership of the International Labour Organization (ILO). If these eventuated, it was thought that Myanmar's retreat from the international community might follow. The decision to forego its turn to chair ASEAN is thus one more move to reduce the opportunities for Western leverage against the government in urging it to undertake genuine reforms. Seen in this light, Yangon's decision, as one commentator expressed it, is 'hardly a reason for a victory parade' (Free Burma Coalition, 28 July 2005; accessed 29 July 2005). The retreat from the international community would make the reopening of substantial political dialogue more difficult; reduce the possibility of nudging the regime in directions of change; and further entrench domestic policies aimed at maintaining political and social control by the military government. How unimportant chairing ASEAN in 2006 really was to Senior General Than Shwe can be gauged by the felicity with which the Chinese Foreign Minister, Li Zhaoxing, left the ASEAN summit and flew, not to Beijing, but directly to Yangon.

If the decision really signals a renewed retreat from the international community, it should be of some concern to those who want to bring about democratic reform in Myanmar. It would also be at odds with the assurances to the contrary which emerged from the new SPDC leadership line-up after the ouster of the former Prime Minister, General Khin Nyunt. During the previous ASEAN summit held in Vientiane, Laos, in November 2004, the new Myanmar Prime Minister, Lt Gen. Soe Win, had assured his counterparts that the Myanmar government remained committed to national reconciliation and a return to Myanmar-style democratic governance as outlined in the 'Roadmap'. This was interpreted as a sign that the new line-up intended to push ahead with the policy path outlined in the Roadmap and the commitment to reform it suggested, and which had been welcomed at the Ninth Bali summit in 2003. Whilst the November 2004 Vientiane summit was in progress, the announcement was issued from Yangon that Daw Aung San Suu Kyi, Secretary General of the opposition National League for Democracy (NLD), would continue to be held under house arrest until at least November 2005, a sign that no amount of external pressure would induce the government to change the path it had resolutely set for itself. At that time, Myanmar's ASEAN colleagues declined to offer public criticism, regarding the matter, in accordance with ASEAN norms, as an internal affair. The new Foreign Minister, H. E. U Nyan Win, present at the summit, stated that he was unaware of 
the announcement as he had left Yangon on 25 November 2004. Clearly, the decision was taken at the highest levels of government. Also coinciding with the 2004 ASEAN summit in Vientiane, was the announcement by Yangon of the release of some 9,000 prisoners, some of whom were long-serving political prisoners, said to be in jail at the behest of the now disbanded National Intelligence Bureau (NIB), a clear public relations gambit by the SPDC leadership, but much welcomed by the former prisoners. It is uncertain how many were former political prisoners as compared with those who were merely common criminals. In the 'theatre' of the July 2005 Vientiane summit, when Daw Suu Kyi's release was presented by the West as a prerequisite to Yangon's being able to assume the chair of ASEAN in 2006, it became an easy decision for Yangon: domestic internal stability and control had much higher priority for the government than did a ceremonial role in a regional organization.

Initially, after the 18 October 2004 purge, the individual state of Myanmar, under its leader, Senior General Than Shwe, gave indications of defining its presence within the international community on the same terms as those previously employed by the allegedly reformist Prime Minister, General Khin Nyunt. At first glance, the individual state's policy of enhancing its security through participation in regional fora was continuing. The state did not withdraw into the isolationism predicted by Larry Jagan (Bangkok Post, 7 December 2004), but sought to strengthen its position within the wider regional community which had been the primary objective of its diplomatic initiatives over the previous couple of years. In the words of Carson McCullers, the ASEAN community has provided the 'weness', the external security cocoon of interrelatedness within which the individual state of Myanmar has had the opportunity to repair the psychosis at the heart of its social fabric. Indications were that continued selective integration into the regional political, economic and security networks would remain SPDC policy, as this would not only strengthen state and regime security, but also increase the psychological spoils of the victors in the recent internal power struggles. Ironically, it has been observed that international tendencies to laud the former Prime Minister as the key agent of change, whilst withholding the resources to bring that change about in an evolutionary manner, may have contributed to his sudden removal from office.

The decision to forego chairmanship of ASEAN in 2006 also coincided with announcements in Yangon of the government's intentions to move key ministries Defence, Foreign Affairs, Home Affairs - to a new purpose-built centre of government up-country at Pyinmana, not far from the old monarchical capital at Mandalay. To many Myanmar watchers, this was interpreted as the SPDC going into the 'bunker', a move consistent with interpretation of its decision on ASEAN as heralding a retreat into isolationism again. The projected move to the new government, site, however, has been in the pipeline for some time and emerges from the Senior General's determination to reassert personal control over the key sectors of national, state and regime security. All in all, Yangon seems to have decided that domestic concerns needed to take priority over international forays which would not return high interest on the investment of time and resources. 
Like the Chinese, Myanmar leaders have simply chosen to go around an obstacle and wait for another day.

In 1995, 2 years before Myanmar became a full-fledged member of ASEAN, Muthiah Alagappa asked the question, 'Why, how, at what levels and within what limits can regionalism contribute to the preservation and enhancement of security? How does it relate to self-help and global approaches to enhancing security?' (Alagappa 1995: 152). Whilst the global-level security dynamic, post-September 11, has changed since Alagappa wrote this, his perception that regionalism, defined as 'sustained cooperation, formal or informal, among governments, non-government organizations or the private sector in three or more contiguous countries for mutual gain' (Alagappa 1995: 158), remains a powerful force in conflict prevention, is worthwhile pursuing in the context of Myanmar's relations with the wider ASEAN community. His focus is on the international security context. Regionalism, for ASEAN member states, has contained intraAsian conflict. However, with respect to internal domestic conflicts, Alagappa considers regionalism less effective in that 'Governments tend to support each other' (Alagappa 1995: 177) reinforcing the ASEAN norm of non-intervention in the internal affairs of member states, a principle which in practice privileges the party in power. Alagappa thus considers regionalism less efficacious in responding to internal conflicts of member states. From this perspective, the moral landscape conditioning the dynamic between the individual (state) and the collective (regional community) is opaque.

However, in recent times, ASEAN announcements on internal matters normally not within the purview of public comment have been modified from 'non-interference' in the internal affairs of members' states, to 'open and frank discussions' (Katsumata 2004: 237-54) and even 'enhanced interaction'. Certainly, there was international consternation expressed, indeed outrage, at the 30 May 2003 attack on Daw Aung San Suu Kyi's cavalcade at Depiyin in northern Myanmar. Former Prime Minister of Malaysia, Dr Mahathir, even raised the spectre of Myanmar being expelled from ASEAN. Japan, Myanmar's long-time friend and main source of external aid, temporarily halted provision of additional aid. Similar disquietude was obvious over the events surrounding the removal from office of General Khin Nyunt, particularly as rumours began to circulate of the underlying links to the Depiyin incident and the mysterious disappearance of the Depiyin files from the Directorate of Defense Services Intelligence (DDSI). ${ }^{11}$ Questions are thus being raised whether membership of ASEAN is becoming somewhat of a stinging nettle for the government in Yangon. Yet, if the SPDC leadership wishes to continue to benefit from the enhanced political legitimacy which membership of the regional organization brings, enjoy the economic advantages of regional trade and participation in the Asian Free Trade Agreement (AFTA), it will need to continue to develop and strengthen its relations with the regional community.

This interdependence draws the Myanmar leadership closer within ASEAN norms, exposes it to collective action and none-too subtle persuasion to continue to move along the reform path, at least in public perception, as a means of strengthening regional cohesion. In this case, the community envelope may 
operate to mitigate the anarchical tendency in the individual state. Alagappa's argument projects forward to the longer-term benefits of regionalism in drawing fragile states like Myanmar into a framework of shared norms and values which can 'strengthen international society and in the long run make for the development of a pluralistic security community' (Alagappa 1995: 178). Alagappa states,

The key assets of regionalism are coordination, collaboration and the power of collective action. ... Through the construction of security regimes in the areas of confidence- and security-building measures, pacific settlement of disputes, and defensive defence, it can mitigate the negative effects of anarchy.

(Ibid.)

The sociological aspects of international relations, particularly in the beneficial consequences of constructed security communities, have been explored further by Amitav Acharya (1998). His view that ASEAN has now become a nascent security community highlights the contributions which the socializing processes of South-East Asian leaders and elites make to the development of regional norms, values and expectations of peaceful resolution of differences. He cites, for example, the situation that Malaysia has unresolved border disputes with all its regional neighbours, but that since the signing of the Treaty of Amity and Cooperation (TAC) in 1976 and the symbolic enthronement of the 'ASEAN Way' of consensus and consultation, no one expects such disputes to lead to inter-state violence. Since the ending of the Indo-China War in 1975, the most violence-fraught border has been that between Thailand and Myanmar, which in 2001-2 hosted a number of incidents in the Kengtung-Tachilek-Mae Sai north-eastern region, and along the southern border. The ascendancy of Prime Minister Thaksin Shinawatra has sought to replace the historical mistrust between Thailand and Myanmar (Burma) with diplomacy and conciliation aimed at drawing Myanmar further into the socializing processes of the nascent ASEAN security community. Acharya (1998) intimates that these processes of collective identity formation and symbol generation within ASEAN hold the key to bringing the newer, less prosperous, and non-democratic members of the nascent security community within the purview of the norms and values shared by the five original members Thailand, Malaysia, The Philippines, Indonesia and Singapore. He argues,

In the ASEAN context, collective identity may be understood as a process and framework through which its member states slowly began to adapt to a 'regional existence' with a view to reducing the likelihood of use of force in inter-state relations.

Moreover,

[B]oth in Deutschian and in constructivist formulations, collective identity is a process that leads to the structural transformation of the Westphalian states system from anarchy to authority. 
It is the underlying implications of this sense of collective identity for policy formulation and governance modes in the domestic context, as well as for behavioural norms in the international context, which has been underrated and misunderstood by proponents of the rational and liberal analyses of ASEAN and critics of ASEAN's constructive engagement policies. If ASEAN had followed through on Dr Mahathir's suggestion of expelling Myanmar from ASEAN following the attack on Daw Aung San Suu Kyi's cavalcade at Depiyin in May 2003, the consequences both for Myanmar and for the ASEAN norm of regional solidarity would have been profound. But no one considered for a moment that such an expulsion would happen; it would have shaken the foundations of ASEAN's regional collective identity. On the other hand, Dr Mahathir's very public suggestion (together with 'friend' Japan's curtailing of additional assistance measures) probably assisted considerably in moving the Yangon government towards taking remedial steps in damage control, announcing the Roadmap and reconvening the National Convention. In this case, the individual state, Myanmar, recognized that, through its own actions, it was jeopardizing its security cocoon within the wider ASEAN community. Myanmar's participation in the resulting 'Bangkok' process in December 2003, evidenced its commitment to that multilateralism which Acharya considers the basic element in ASEAN's collective identity formation, a framework for 'encouraging the socialization of elites, which facilitates problemsolving' (Acharya 1998: 208). That collective identity is underpinned by the ground rules of inter-state relations within the ASEAN community as articulated in the TAC at the first meeting of ASEAN leaders in Bali in 1976. They are

Mutual respect for the independence, sovereignty, territorial integrity of all nations;

The right of every state to lead its national existence free from external interference, subversion and coercion;

Non-interference in the internal affairs of one another;

Settlement of differences and disputes by peaceful means; and

Renunciation of the threat of use of force. ${ }^{12}$

Of these, perhaps the most challenged has been the third one: non-interference in the internal affairs of one another. It gave rise to the concept of 'flexible engagement' articulated in 1998 during the term of former Thai Foreign Minister, Surin Pitsuwan, whose notion was supported by The Philippines, but rejected outright by other ASEAN members, especially Indonesia and Malaysia. These two countries considered that any resiling from the principle of non-interference at that time would not only jeopardize their own regimes, but also lead to the unravelling of the ASEAN Way. ${ }^{13}$ The symbolic power of the ASEAN Way, as noted by Acharya (1998: 210), has been a significant element in the construction of ASEAN's collective identity, and one adhered to resolutely by the more authoritarian members of ASEAN. ${ }^{14}$

But if the sense of community and regional solidarity has underpinned ASEAN's refusal to countenance the Western sanctions approach to Myanmar, its 
continued support for Myanmar's membership in the regional organization and its staunch determination to ensure Myanmar a place in the ASEM-EU meeting in Hanoi in October 2004, it also underpins an unspoken, but equally firm determination by ASEAN to ensure that Myanmar does not bring discredit or embarrassment to the ASEAN security community - that is, to cause ASEAN to lose its collective face, and hard-won respect as a diplomatic entity within the international community. It is this element which motivates certain ASEAN leaders to encourage Myanmar, within the framework of the ASEAN Way, to move towards closer alignment with regional neighbours in terms of its domestic reform policies. The socializing experience of the ASEAN elites has produced a we-ness which is imperilled if any member fails to live up to expectations generated by the symbolic norms. Whilst it has been said that the new troika in Yangon (Than Shwe, Maung Aye and Soe Win) have less regard for ASEAN than ASEAN would like, it is also noteworthy that they continue to participate in regional fora and do not give any sign of withdrawing from the Association, suggesting that the socialization experience both for them and their colleagues may pay dividends in future.

Certainly, Acharya is correct in highlighting the present deficiency in ASEAN community building and collective identity formulation in that it appears to be confined to the elite intergovernmental level. He notes, 'This kind of regionalism does not translate into cooperation or development of "we-feeling" at the societal level' (Acharya 1998: 215). However, in recent years, and particularly since the fall of Suharto (1998), the greater prominence of civil society organizations in bringing about socio-political change in key ASEAN countries - Thailand, Indonesia, The Philippines, Malaysia - suggests that there is a regional network developing at the societal level, amongst educational institutions, non-governmental organizations, religious, professional and business associations which is moving ASEAN governmental elites towards greater consideration of human security issues (Noda 1998, 1999; Thiparat 2001). Moreover, the devastation wreaked by the tsunami on 26 December 2004 has demonstrated the necessity for governmental elites to work together with both the international community and their own civil societies in coming to terms with, raising funds for and alleviating the human suffering involved in the mass destruction. Acharya draws attention to the growing capacity of regional civil society to oppose official ASEAN regionalism on human rights, environment and democracy issues, and what he calls the 'incompleteness of the community-building enterprise led by the ASEAN elites' (Acharya 1998: 216); but it is also possible that ASEAN regionalism is changing under the combined effects of its civil society groups and the obvious exigencies of the need to mitigate human insecurities. Not the least of these are those originating from nature which clearly could have political, as well as dire social and economic consequences for the states and governments in the affected countries, if their policies for the alleviation of the human suffering caused by the tsunami or similar natural disasters are judged inadequate. If this is so, then the 'we-feeling' at the societal level is already present, nascent, perhaps subdued, but ready to present a more overt community presence both internationally and in the domestic sphere. Enhancement of these trends will be conditional on the continued 
strengthening of domestic civil society groups in ASEAN member countries and their networking interactions with international counterparts.

\section{Human rights and the security discourse}

Protection and enhancement of human rights, as discussed in Chapter 1, are at the heart of the human security concept. Whilst the UDHR (1948) and the two related international covenants (1966) on Economic, Social and Cultural, and Political and Civil Rights have given rise to a formidable body of international law on the responsibility of governments and the international community to protect human rights, the central position which human rights policy now occupies in international relations has become prominent only since the end of the Cold War (1989). Prior to that, democratic governments often chose to ignore the human rights violations of their Cold War (1950-89) dictator allies, if the exigencies of international politics required. Former Chilean dictator Augusto Pinochet is one example; the late Philippines dictator Ferdinand Marcos is another.

Coinciding with the international policies of the US Clinton Administration, in the legislative and normative practices of the Security Council, human rights have been 'securitized'; part of an evolving framework of democratic legitimacy which is seen to be mandatory to maintaining international peace and security (Ramcharan 2002a). International tribunals and the International Criminal Court (ICC) set up to prosecute those accused of war crimes and crimes against humanity as in cases arising from the civil wars in Rwanda and the former Yugoslavia, are a measure of the international community's commitment to the protection of international human rights and humanitarian law. Recent prosecutions under their own national justice systems of British and American military personnel accused of egregious human rights abuses against Iraqi prisoners are testimony to the domestic socialization of these international human rights norms. Yet 'securitization' of human rights in the wake of the September 11, 2001, tragedy, saw the debate on 'intervention for human protection purposes' take a sharp turn away from 'intervention on behalf of others' to 'intervention in self-defence'. Serious concern for the implications of this development for human rights led Secretary General of the UN Kofi Annan, to ask, 'How much freedom do you give up for security and safety? And if you give up too much, do you in the end have security or safety?'(Ramcharan 2002a: 8). From this perspective, both national and international security are impugned when individual human rights are set aside in favour of the collective good, ${ }^{15}$ a harbinger of the potential return to authoritarian governance in the halls of democracy, which sends an unfortunate message to those countries whose governments routinely disregard human rights in the name of collective security of the state and regime in power. In the words of Stefan Collignon (2001: 74) 'democracy dies when a group, regardless of whether it represents a majority or minority, exerts its power without respect for these individual rights'.

The securitization of human rights has been a characteristic of Burmese/ Myanmar state ideology since independence in 1948. During the 50 years of 
civil war, ethnic insurgencies and domestic challenges to the identity of the state, repression of human rights - economic, social and cultural as well as civil and political - has been justified by whichever group was in power in Yangon, both during the era of so-called parliamentary democracy (1948-58, 1960-2) and successive military governments (1958-60, 1962-to the present) on the grounds of the need to maintain state unity, peace and stability. Systemic, egregious and ongoing abuses of human rights in Myanmar have been the subject of numerous reports by the UN rapporteur on Human Rights, HE Professor Paulo Sergio Pinheiro and international organizations (Human Rights Watch, Amnesty International, International Committee for the Red Cross) as well as academics and journalists (Smith 1991, rpt. 1999; Lintner 1994; Roy 1997; Lambrecht 2004). It is not my intention to revisit these scenes, but rather to seek a way forward to realizing a future framework wherein Myanmar may be released from her violent past.

During the term of office of the late General Ne Win (1962-88) the 'securitization of human rights' was justified in the military government's manifestos, the Burmese Way to Socialism and Correlation of Man and His Environment. Under this ideology, the individual egotistical human nature was to be strictly subordinated to the social, economic, cultural and political requirements of the state. Such an approach to governance has seen the 'capabilities' of Myanmar's people minimized. Endemic poverty - both material and political - has limited their opportunities and disempowered the majority of the population. Periodic purges arising from internal power struggles have often removed from office those capable of moving the country towards norms of governance more in accord with contemporary international expectations.

The dire economic consequences of these policies which led to the state being declared a Least Developed Country (LDC) in 1987, spurred the military government (SLORC-SPDC) which took over from General Ne Win, to repeal the socialist economic framework and enact legislation in 1989-90 giving effect to a titular market economy. Although the economy still includes considerable state intervention, subsidies of deficit producing state-owned-enterprises and an inefficient tax and revenue collection system, these initial reforms saw the re-emergence of a nascent civil society in Myanmar (Tin Maung Maung Than 1998; Steinberg 2001; James 2003, 2005), a development which may eventually assist in rolling back the securitization of human rights in this country. Such a development will require the transformation of the paradigm of mutual fear which has governed state-people relations for more than half a century; in essence, a transformation of the systemic structure and operational norms of the Myanmar state.

Along these lines, Collignon (2001) has called for the replacement of the current cognitive model of Myanmar society based on hierarchy, status, authority and patron-client relations with one based on interest, wealth and rights. Collignon observes that 'The idea that the collective may have an obligation towards an individual and that, therefore, citizens may be entitled to make claims against the state, simply has no meaning' in Myanmar (Collignon 2001: 80). Thus, he argues, 
the cognitive reference system for human rights in Myanmar is missing because dialogue and compromise are not an integral part of Myanmar social, political and cultural norms. Rather, systemic reforms of the Myanmar state will be required, to 'lay the foundations for a society where human rights will become a constitutive norm' (Collignon 2001: 85). In a state characterized by highly insecure human and property rights, Collignon draws attention to the need for farreaching social and economic reforms as precursors to the creation of a modern values system which privileges individual rights over the collective perspective. He argues,

Respecting human rights in Burma requires more than just a change of government. That may be necessary, but it is not a sufficient condition. What is needed is a profound change in culture where the universal norms of a modern world are accepted and reproduced as a basis for everyday life. These norms underlie the concepts of human rights and property rights. Both protect the individual, the former against collective, the latter against individual encroachment.

(Collignon 2001: 104)

Contrary to some views held in the international community and in Myanmar's domestic opposition groups, Collignon argues that improving respect for human rights in Myanmar requires that political and economic reforms must go in tandem: neither one nor the other seen as primary, but both mutually reinforcing the other. Comparison with other emerging and robust democracies (Japan, Thailand, Korea, Taiwan, The Philippines) confirms the views of Land and Ersson (2000: 280) that human rights are better protected in prosperous societies. 'There is a strong positive correlation between economic freedom and human rights (ie democracy).- affluence is the crucial factor' they argue (Land and Ersson 2000: 280). Reconstructing the Myanmar state therefore will require not just financial and economic reforms to remove the permanent condition of macroeconomic instability arising from budget deficits; nor redefining centre-periphery relations to institute a set of modern administrative structures and functional responsibilities at the central, provincial and local levels of government; nor even finding common ground for dialogue and compromise among the mutually distrustful SPDC, opposition and ethnic nationality groups - although all of these are important but fundamentally transforming the sociocultural and political norms to create what Colignon (2001: 83) calls, 'the normative validity of human rights' so that the cognitive underpinning of human rights is not considered an alien concept.

The question remains, how can such cognitive underpinning be institutionalized within the state of Myanmar's domestic policies? One avenue will be through the norm generating and enhancing socialization processes of ASEAN and participation in other similar international and regional bodies. If human security issues are finding greater space on ASEAN's agenda as Noda $(1998,1999)$ and Thiparat (2001) claim, then continued participation in the summits, dialogues and negotiations of the regional forum should theoretically assist in socializing the 
association's norms within the domestic policies of the Myanmar state. But all ASEAN governments are not democracies, and observance of human rights within ASEAN member countries is still problematic as exemplified by the repression of the Muslim population in Southern Thailand. Then again there is the issue of transfer of normative change between the elite levels and the societal networks.

In the 'spiral' model of Risse, Ropp and Sikkink (1999) domestic institutionalization of international human rights norms within an abuser country proceeds through a series of socialization phases. The first, or denial phase, exhibits the abuser country denying that certain incidents occurred. According to Risse, Ropp and Sikkink by the time the abuser country has entered this phase, it has already implicitly acknowledged the validity of international human rights norms. In effect, the socialization process has already begun and is moving from the elite levels into the intermediate or bureaucratic policy-making and implementing levels of government. They argue,

[T]he fact that the state feels compelled to deny charges demonstrates that a process of international socialization is already under way. If socialization were not yet under way, the state would feel no need to deny the accusations that are made. Governments which publicly deny the validity of international human rights norms as interference in internal affairs, are at least implicitly aware that they face a problem in terms of their international reputation. It is interesting to note... that denial of the norm almost never takes the form of open rejection of human rights, but is mostly expressed in terms of reference to an allegedly more valid international norm, in this case national sovereignty. Nevertheless the denial stage can also last for quite a long time.

(Risse, Ropp and Sikkink 1999: 23)

An abuser state moving into the next phase offers tactical concessions: release of political prisoners, moves towards constitutional government, even punishment of human rights offenders. But this, in their view, is motivated by an objective to buy time, rather than fundamental and sustainable change in human rights behaviour. Only in the final phase, in the institutionalization of what Land and Ersson call 'constitutive government', that is, governed by a robust constitution and a vigorous civil society which place practical limits on the capacity of state leaders and bureaucrats to use the resources of the society for personal benefit does the former abuser state exhibit full socialization of human rights norms in their domestic policies. Clearly, Myanmar is certainly within the first or denial phase (as shown by H. E. Dr Kyaw Win's statement to the UN General Assembly, November 2003) and may be moving hesitantly into the second phase (as shown by the release of some 9,000 prisoners in November 2004), but certainly has a long way to go before entering the final phase.

What can encourage an abuser state, such as Myanmar, Risse, Ropp and Sikkink ask, to enter the final phase - to slough off the 'pariah' status clamped on it by the international community in response to its long history of human rights 
abuses and authoritarian governance? Their answer is fairly simple: pressure both from what they call 'above', that is, the international community, and from 'below', the network of domestic and international civil society groups which not only spotlight continuing deficiencies in human rights protection, but also positively move the offender country towards more constructive measures which will enhance human capabilities within the broader social fabric. Modern statehood then is recognizable by how thoroughly international human rights norms have become institutionalized within the modes of domestic governance and have obviated the offender polity's reflexive reaction to 'national sovereignty' to justify failure to protect human rights. Moving to this final stage requires the efficacy of argumentation and persuasion in a process of state identity transformation such as occurred in The Philippines after the deposing of President Marcos, and is ongoing in Indonesia in the post-Suharto era.

ASEAN elites would argue that the opportunities to spur Myanmar into this final phase occur through its constructive engagement policy. However, in the view of Risse, Ropp and Sikkink, ASEAN's constructive engagement policy with Myanmar is only likely to be effective in the final stage of Myanmar's evolution from traditional polity, wherein individual rights are subordinated to the collective will, to modern state (Risse, Ropp and Sikkink 1999: 277-8); and may be ineffective in earlier stages. It could be argued, however, that opportunities for persuasion and argumentation which they see as critical to the socialization processes and institutionalization of human rights within the domestic policies of the pariah country, will be present in the two earlier phases of their spiral model, and without such opportunities progress through their various phases will be impeded. Moreover, if moving to phase three is spurred by the offender state's desire to be well-regarded in the international community, their model presupposes that state leaders care about their international image, or desire some other tangible benefit such as restoration of international aid. This, however, may not always be the case and suggests a reversion to an instrumentalist rather than ideationalist perspective of how international human rights norms become institutionalized within former offender polities. One recalls the Myanmar state's outright rejection of the 1998 World Bank offer of considerable economic assistance (USD 20 million) if the government would move substantially towards restoration of democratic governance. Such an offer was at odds with Myanmar elite cultural values and domestic norms; and served to encourage nationalistic fervour.

Greater efficacy is likely to be generated through processes of state identity transformation produced from within the polity by changing cultural norms, rather than imposed externally. As Collignon has argued above, in Myanmar's case, this will require changing the cognitive paradigm for human rights within the country's sociocultural fabric. One notes the efforts of the Australian government to contribute to such transformation through the series of Human Rights Workshops it conducted for middle level public servants in Myanmar; these have been suspended since the 30 May 2003 incident at Depiyin. The fact that permission was given by the Myanmar government for them to be held, however, could 
be seen as a sign of Myanmar moving into phase two of Risse, Ropp and Sikkink's model of state behavioural change. A further sign could be the establishment of a Human Rights Commission in Myanmar, also done with international encouragement, and the opening of an office of the ILO to monitor incidents of forced labour and related practices. However, state actions subsequent to the purge of former Prime Minister General Khin Nyunt and his circle and the continuing detention of Daw Aung San Suu Kyi suggest that Myanmar has not moved beyond the first phase of the spiral model. Much persuasion, encouragement, argumentation and socialization of international norms will be required. As Risse, Ropp and Sikkink argue,

The process of human rights change almost always begins with some instrumentally or strategically motivated adaptation by national governments to growing domestic and transnational pressures.... Even instrumental adoption of human rights norms, if it leads to domestic structural change such as re-democratization, sets into motion a process of identity transformation, so that norms initially adopted for instrumental reasons are later maintained for reasons of belief and identity.

(Risse, Ropp and Sikkink 1999: 10)

In the following chapter, I turn to examine the dynamics of this necessary identity transformation in the border regions amongst the ethnic minority peoples where some of the most egregious human rights abuses have been recorded and where human insecurity has been the predominant life experience of the peoples since the inception of the independent state in 1948. Improvement in their well-being will be the litmus test of a changing corporate identity in the state of Myanmar. 


\title{
3 The seven horsemen of the apocalypse
}

\author{
Strategies for effective poverty \\ alleviation amongst the peoples of \\ the poppy cultures
}

\section{Introduction}

Since 1948, the border regions, home of the indigenous ethnic minority peoples ${ }^{1}$ which make up approximately one third of Myanmar's population, have been perceived by successive governments in Burma/Myanmar to constitute the prime security threat to the unity and stability of the independent state. The resulting dynamic of conflict and resistance between the core, Burman heartland and the indigenous ethnic minority peoples on the 'periphery' of the nation state, for more than five decades has drained the resources of the country and made war, famine, conquest and pestilence the predominant life experience for those living in both 'core' and periphery. Insecurity in economic matters, food, health, environment, personal insecurity, community insecurity and political insecurity - the vectors I designate 'the seven horsemen of the apocalypse' - have diminished the opportunities to enhance both the material and non-material aspects of human security and well-being for the people of Myanmar.

In a very poor country where per capita income for 2001 was estimated by UNDP (2001: 143) at USD 1,000 (purchasing power parity), the border regions provide evidence of widespread and dire indigence. In these border regions where, since the late nineteenth century the economy has been based primarily on cultivation of the opium poppy, endemic poverty has been the lot of children for generations. In 2004, the UN Office of Drugs and Crime (UNODC) estimated annual income for poppy farmers was a mere USD 214, as distinct from the fortunes made from the opium poppy trade by the middlemen and downstream drug syndicates tied into international networks operating out of Thailand and Hong Kong. Poverty and poppy farming in the mountainous border regions of Myanmar go hand in hand, the one indicative of the other.

Likewise, poverty and insecurity go hand in hand. Poppy farmers till their small plots, often located on the tops of mountain ridges where other crops will not grow, and frequently have sufficient food for only 6 months of the year (personal communication, CCDAC, February 2004). Food insecurity in these conditions is prevalent, in addition to all other types of insecurity which can beset a human being. To the extent that the border regions of Myanmar suffer from widespread and endemic poverty, they do indeed place the security of the state in jeopardy. 
The dynamic of poverty and insecurity extends well beyond the localized state-centric discourse of intra-communal conflict which has marred the modern history of Burma/Myanmar. The international dimensions of the poppy cultures and their attendant socio-economic and politico-civil insecurities require, as Renard (1996) has argued, international cooperation to resolve; effective poverty-alleviation strategies involving synthesis of local, domestic and international policies, resources and leadership are fundamental to achieving long-term, sustainable solutions to the problems of supply and demand for the drugs emanating from Myanmar's northern border regions. As Renard stated in 1996,

Burma is thus confronted with the question of how to control a problem that extends well beyond its borders. Any Burmese government... would agree...

If Burma's Nobel Peace Prize winner, Aung San Suu Kyi, somehow came to power in a democratic or federal government, the opium and other traders on the border would not stop their activities in a show of respect for the country's new leadership.... solutions will require the cooperation of neighbouring countries... . Regardless of Burma's politics, economy, or human rights record, there is agreement among the interested parties that narcotics problems in Burma can only be solved through the active assistance of the Burmese government.

(Renard 1996: 5-8)

Whilst the border regions which hosted the ethnic insurgencies (1948-89) have been conceptualized in terms of state security in the public discourse of successive Burmese/Myanmar governments - and the indigenous ethnic minority peoples treated as 'enemies of the state' - it is the primary experience of human insecurity in these areas which should be the focus of local, state and international policies. State security is jeopardized when poverty and inequality plague the lives of millions; global order is compromised by the deepening poverty and inequality between core industrialized countries and the periphery developing world. At UNCTAD, Bangkok, in 2000, Michael Camdessus, then Managing Director of the IMF declared: 'Poverty is the ultimate systemic threat facing humanity' in face of the global statistic of 1.2 billion people living on less than USD1 per day. Enunciation of the UN's Millennium Development Goals to combat poverty, and the 2002 Johannesburg Conference on Sustainable Development have contributed little in practical terms to improving the livelihoods of the world's poor, nations as well as individuals. This gap between rhetoric and reality is painfully clear in Kofi Annan's 22 March 2005 announcements of a thoroughgoing overhaul of the UN's operations, including its Human Rights Commission, with his call for more concerted resources to be focussed on alleviation of poverty in the developing world.

This interlinkage between poverty and security, the likely catastrophic effects for world security of the uneven distribution of the benefits of globalization, led Caroline Thomas (2000) to investigate the causes of human insecurity and the concomitant pursuit of human security, through what she calls the 'convergence' 
of development and security. She dissociated her research from what she styled 'the competitive, possessive notions of security of the individual conceived in the currently fashionable neoliberal sense' and declared that human security, for the majority of human beings is pursued 'as part of a collective, most commonly the household, sometimes the community defined along other lines such as religion, caste, ethnicity or gender, or a combination of these. States play a critical role in the achievement of human security; they have the authority and the responsibility to attend to the human security needs of their citizens' (Thomas 2000: xi).

Such needs, Thomas declares, are both material and non-material, require satisfaction of basic needs - food, shelter, education, health care, clean potable water - but also fulfilment of the capacity to participate fully in the life of the community, local and global, that is, the elements which enhance the human dignity at the core of the human security concept, and whose absence imperils both human and state security. The security of the state is thus contingent on meeting the human security needs of the individual, shedding 'oppressive power structures' and putting in place the institutions for unhindered participation in substantive democratic governance (Thomas 2000: 6). The seven vectors of human insecurity discussed in Chapter 1, can be borne by the structures of both state and global governance. The consequential impoverishment of the political, social, economic and cultural lifeways undermines human security at the local, national and global levels.

Spotlighting the convergence between development and security has enabled Thomas to centre poverty alleviation as a core issue for international relations and international politics, a perspective articulated by outgoing President of the World Bank, James Wolfensohn, who stated in his address to the Security Council, 'If we want to prevent violent conflict, we need a comprehensive, equitable, and inclusive approach to development' (Thomas 2000: 3). Entrenched poverty in the marginalized LDCs exacerbated by inequitable development policies generated by the industrialized world undermines the security of all. It remains to be seen whether Paul Wolfowitz, President George W. Bush's nominee to replace James Wolfensohn as President of the World Bank, will continue to consider the eradication of global poverty the primary pillar for enhancing security - human, as well as state and global. As Ross Buckley, Tim Fischer Centre for Global Trade and Finance, Bond University, has warned: 'global poverty and inequality fertilise the fields of anger and hatred in which terrorism flourishes' (The Canberra Times, 21 March 2005). ${ }^{2}$ Security, poverty and development are thus inextricably intertwined.

\section{Security and development}

\section{Development of the border areas and indigenous ethnic minority peoples}

Conscious of the nexus between security and development, following the 1989 ceasefires with key ethnic minority insurgent groups, the Myanmar government 
in 1992 established a Ministry for the Progress of Border Areas and National Races and Development Affairs, with a budget of 1,000 million kyat. Resources for development were a critical aspect of the peace negotiations, for ethnic minority leaders held vivid memories of the asymmetrical development between the core heartland of the majority Burman population and the periphery homelands of the indigenous ethnic minority peoples. This issue had caused grievance even during the post-independence era of parliamentary democracy under the late premier, $\mathrm{U} \mathrm{Nu}$, and was a significant contributing element in the irruption and prolongation of the civil war in Burma/Myanmar, as indigenous ethnic minority leaders keenly felt the sense of institutionalized discrimination against their peoples by the newly created nation state. As Keal argues,

The story of the expansion of international society is one of state formation which often resulted in the decimation of indigenous peoples or, if not that, at least the destruction of their cultures. Indigenous peoples were isolated from state formation and largely excluded from the full rights enjoyed by citizens of the states that are the members of international society. Understanding the reasons for this exclusion and how the rights of indigenous peoples are more recently being incorporated into the norms of international society is necessary to making the story of the expansion of international society more complete than it has been.

(Keal 2003: 3)

Such norms encompass inclusion within the UN's human rights and selfdetermination agenda; recognition of and participation in the 'right to development' as a human right, as articulated at the 1993 Vienna Declaration and Programme of Action; and legal protection within the scope of the UN covenants, the ICCPR and the ICESCR. The Myanmar government's 1992 creation of the new Ministry for the Progress of Border Areas and National Races and Development Affairs was to initiate the first step towards the right to development and effective poverty alleviation in the border regions.

A key responsibility of the new Ministry, in collaboration with other Ministries (Health, Education, Home Affairs, Agriculture, Transportation, Religious Affairs) was to put in place the infrastructure for socio-economic development: education, health care, communication and transportation networks. However, implementation of this policy presupposes government control of such areas; even at the present time (2005), after ceasefires with some 17 formerly insurgent groups have been in place for a number of years, government control is problematic and constantly subject to re-negotiation as demonstrated by the clash in Eastern Shan States in late 2004 between UWSA troops and a unit of the Myanmar army precipitately sent to disarm them, in contravention of the ceasefire agreements.

According to official documentation, over 400 primary schools, 49 sixteen-bed hospitals, 78 health clinics, 26 rural health centres, and 43 sub-rural health centres (Ministry of Health 2001) have been constructed in the border regions since 1992 (Plate 3.1). A separate University for the Development of the Border 


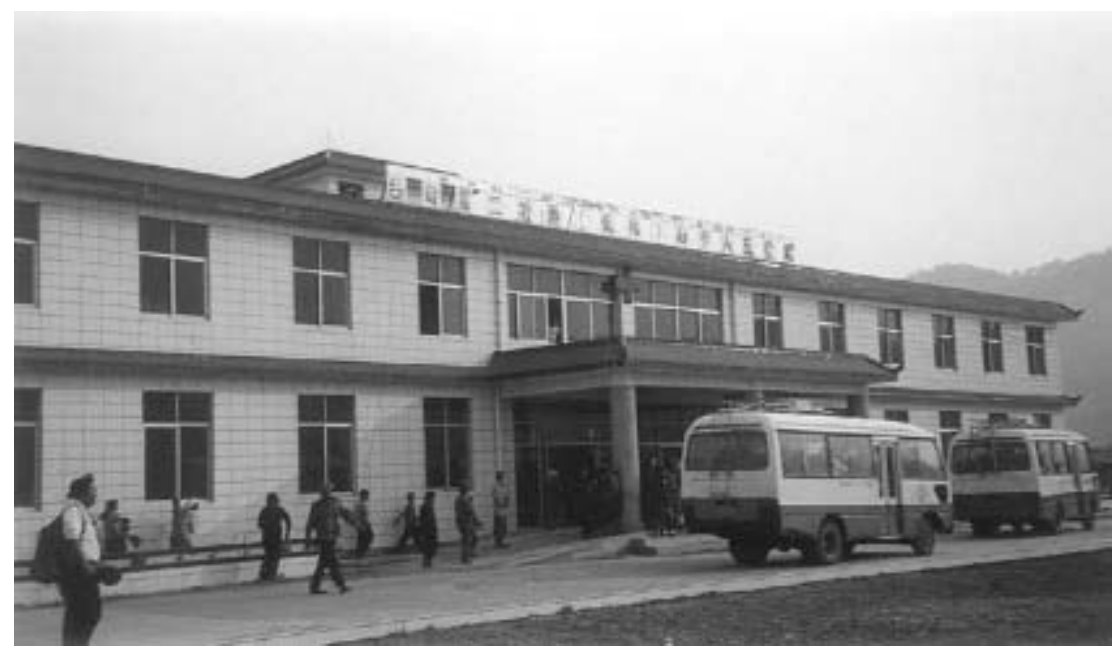

Plate 3.1 Mong Pauk hospital on Myanmar-China border.

Areas and National Races has been opened and a second one at historic Panglong. On a trip to the Eastern Shan States in February 2004 to inspect some of this infrastructure, I was struck by its newness, its apparent lack of use, pupils, or patients, but this may have been a temporary situation not indicative of the operations of the development programme at other sites (Plates 3.2 and 3.3). A 50-bed rehabilitation hospital for drug addicts at Mong Pauk, a site on the China border, for example, was well patronized, with most of the beds occupied by Shan-speaking patients undergoing detoxification. This hospital had been established with funding from China; it carries large Chinese characters on its front façade.

In view of inadequate resourcing, how effective these institutions are in raising educational levels and delivering improved health care to the ethnic minority peoples they purportedly serve, is open to question. Nevertheless, it is better to have such infrastructure, than for it to be absent, and to gradually work on the issues which inhibit its effectiveness. This is not a criticism of the development policy as such, given the political and economic difficulties which beset the programme; rather a statement about the practicalities of bringing effective poverty-alleviation programmes to this vast region marked by impenetrable jungles, towering mountain ranges and precipitous gorges, much of which is accessible only by helicopter, or on foot. As Martin Smith asserts, despite criticism of the quality of the development programme from anti-Government groups and cynicism regarding its strategic objectives, its implementation is tangible evidence of a substantial level of cooperation between the formerly insurgent groups and the Myanmar government which has 'decisively changed the military and political balance in much of the country' (Smith 1991, rpt. 1999: 441). 


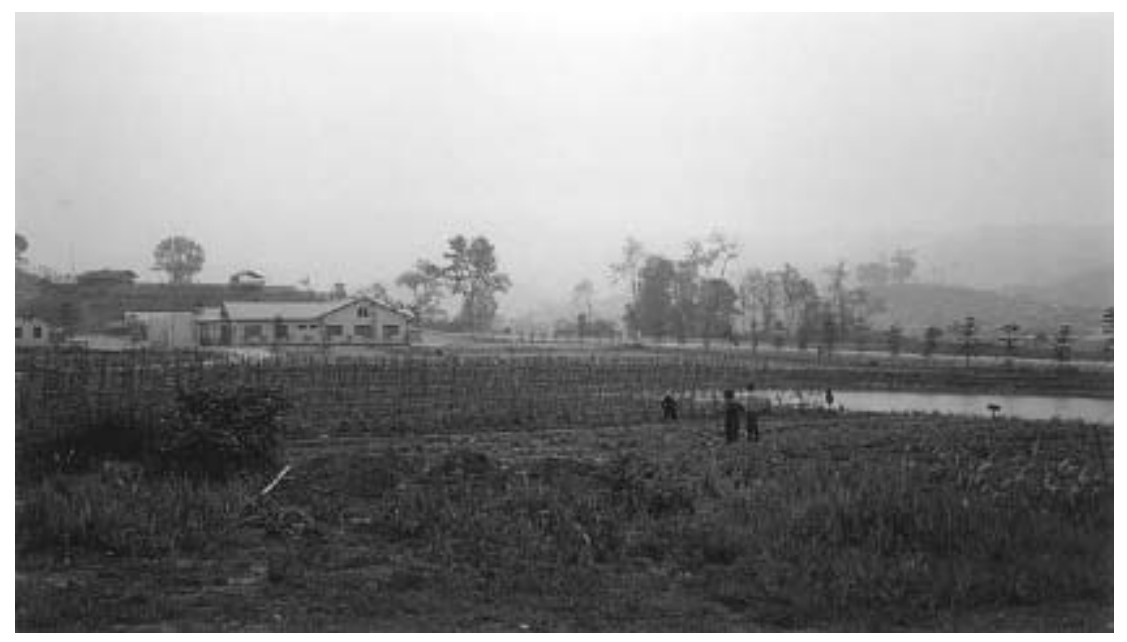

Plate 3.2 Yong Kha hospital and market gardens.

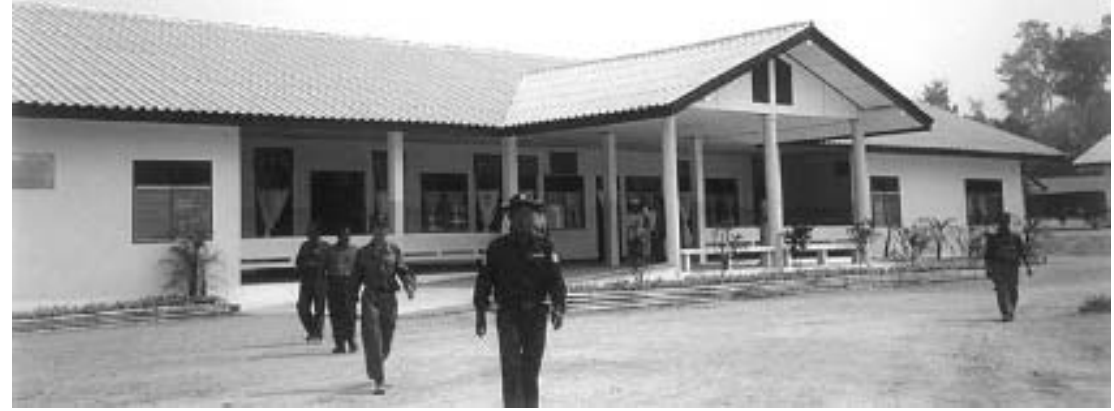

Plate 3.3 Front view of Yong Kha hospital.

Visiting 10 sites in Eastern Shan States in February 2004 where there was an official programme, with international support from UNODC (funded by Germany, Japan and the US), to replace the poppy culture with an economy of alternate cash crops (cashews, various rices, coffee, fruits, mixed farming) I was conscious that our party of 38 (mostly international visitors) was there very much by the grace of our ethnic minority hosts, the Wa leadership (Plates 3.4 and 3.5). Upon asking 


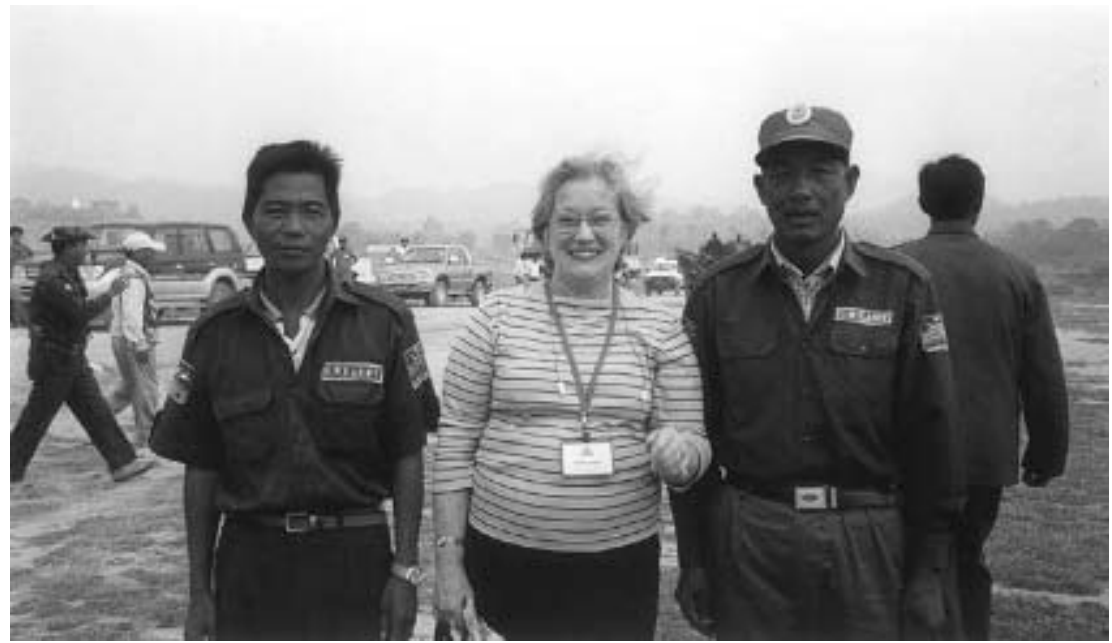

Plate 3.4 Helen James with the United Wa State Army (UWSA).

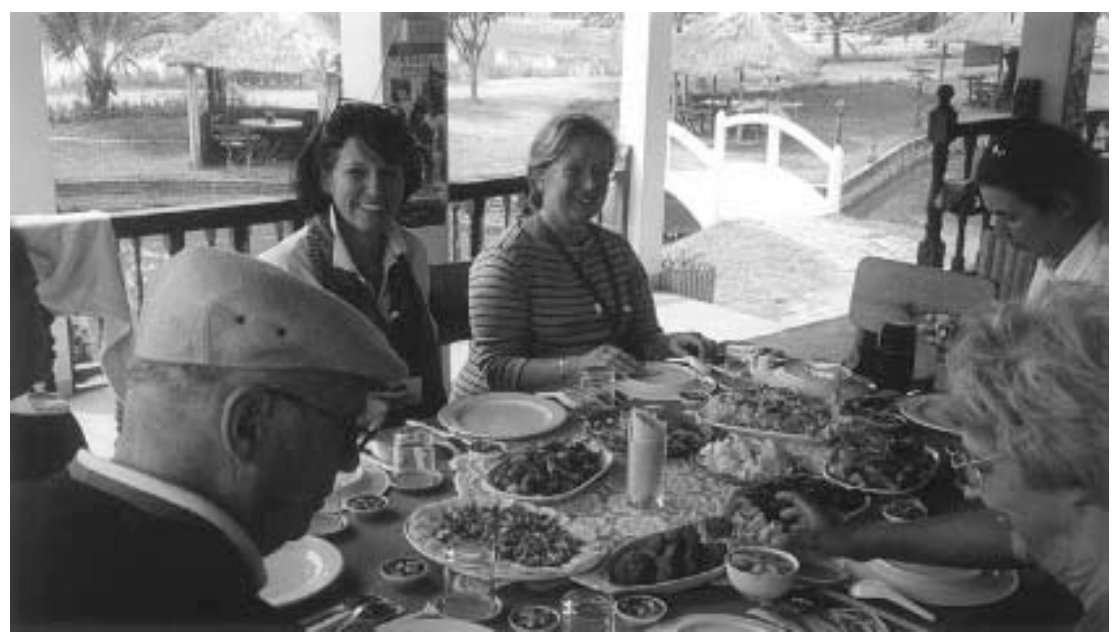

Plate 3.5 Lunch outside Kengtung.

whether this was 'autonomy, or decentralization' in practice, a government representative told me: 'Not autonomy, not decentralization. The central government is working through the ethnic minority leaders, i.e. the Wa.' However, it seemed quite apparent that actual control on the ground, at the local level was indeed in the hands of the Wa leadership, and that government forces, representatives, and international guests entered that locality by invitation - that is, government presence in 
the area was still very much a negotiated entity, not a given. Living on the margins of the nation state, the Wa leadership was continuing to negotiate the terms of their inclusion. Marginality, as Sam Nolutshungu (1996: 19) has observed, 'is not always unilaterally imposed on a group that otherwise wishes to be fully integrated'. In this sense, the Wa (of ethnic Mon-Khmer origin, as distinct from the Kokangese who are ethnically Chinese) differ from some other ethnic minority populations in nation states in Europe which have been forcefully marginalized and subject to 'ethnic cleansing' operations (e.g. The Romany or Gypsy population in Eastern Europe) as the new state imposes its corporate identity (Rae 2002).

The indigenous ethnic minority peoples in Burma/Myanmar who fuelled the insurgencies 1948-89 (and even up to now in the case of the Karen with whom peace negotiations are ongoing, despite a 'gentleman's agreement' with the Myanmar government in early 2004) have embraced marginalization as a means to maintain their own cultural identity, political autonomy, and economic independence, removed from the administrative reaches of the central government (Plates 3.6, 3.7 and 3.8). Their experience may be distinguished from that of the Muslim Rohingya in south-western Rakhine state. Refugees from the state in the early 1990s and late 2003, the Rohingya experience comes perilously close to ethnic cleansing as violence committed by Buddhist groups forced the Muslim population to seek sanctuary across the border in Bangladesh. The Chin of Chin state in north-western Myanmar are also distinguished as the only major ethnic minority group in 1948 not to have taken up arms against the newly constituted nation state.

Asking 'Who is marginal?' Nolutshungu identifies marginal populations as 'distinguishable minorities within states whose integration to the society and state is markedly incomplete so that their participation either is partial or intermittent

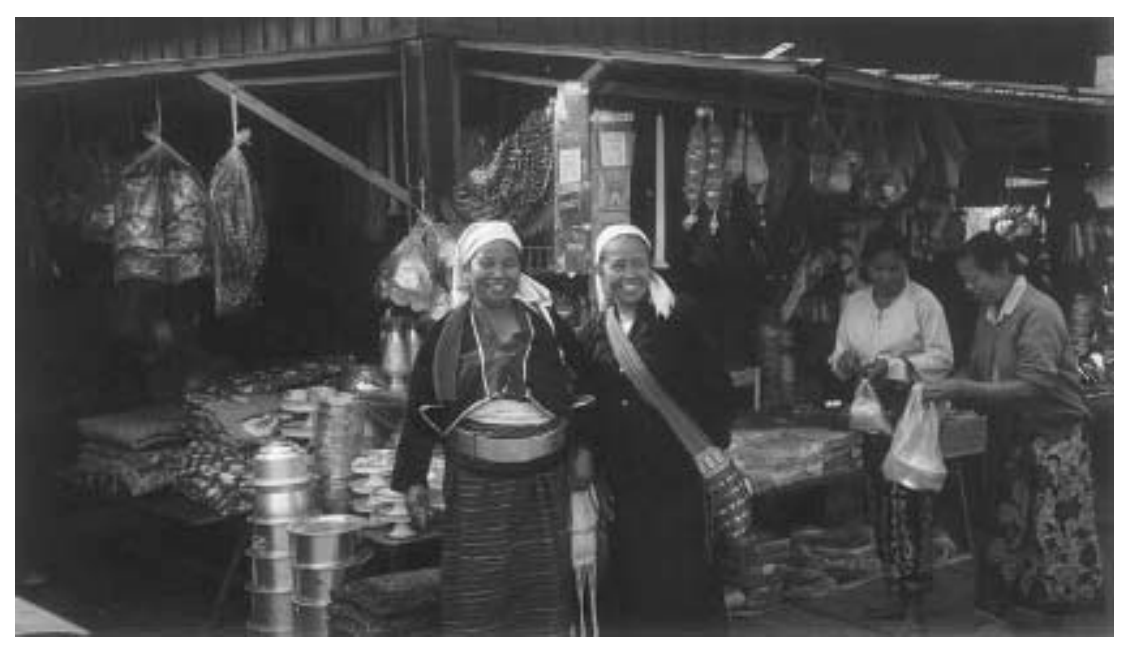

Plate 3.6 Ethnic minority (Shan) women, Kengtung market. 


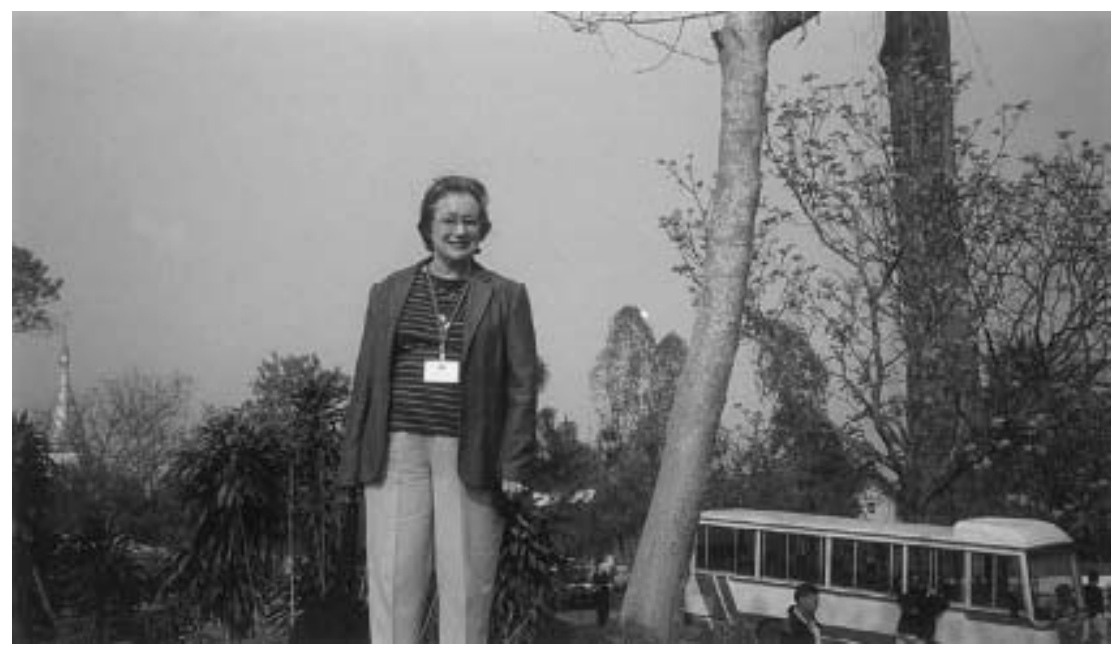

Plate 3.7 Helen James, Kengtung hill.

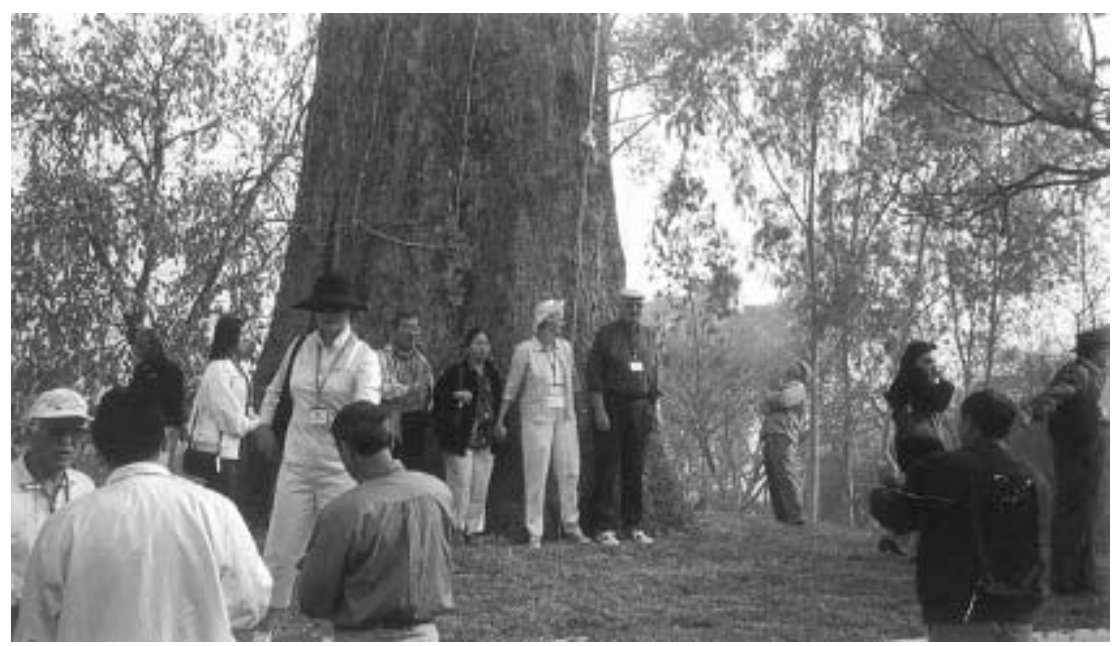

Plate 3.8 The tallest tree, 500 metres in height, Kengtung hill - used during civil war as target practice.

or subject to special qualifications and restrictions' (Nolutshungu 1996: 17). Such peoples are 'usually disadvantaged and oppressed' (ibid.: 19), undergoing the seven vectors of human insecurity (UNDP 1994: 25) - economic, food, health, environment, personal, community and political - as the primary life experience. In the words of David Laitin (1996: 37) 'the livelihood of marginal populations is egregiously insecure'. For the ethnic populations who fought the 50 -year civil war 
in Burma/Myanmar - the Mon, Shan, Kachin, Wa, Kokang, Karen, Kayah and others - such insecurity has defined their relationship with the emerging nation state. Overcoming the dynamic of secession-integration requires a fundamental policy shift within the leaderships of both the nation state and the indigenous ethnic minority peoples to negotiate the terms of inclusiveness on a mutually satisfactory basis, neither by state imposed patterns of domination and submission, nor by artificially maintained boundaries of exclusion which perpetuate indigence and insecurity. As Nolutshungu argues,

Marginality as linked to inequality and differential participation within a given political and economic space, and the accompanying vulnerability and insecurity, were well-known in pre-modern states and in political formations that preceded nation-states. State formation is very much a process of drawing conceptual frontiers of inclusion and exclusion. Moreover, non-state entities like ethnic groups - in their complex articulation to prevailing systems of power and states - also define themselves largely by the boundaries they maintain.

(Nolutshungu 1996: 289)

In mainland South-East Asia, drawing populations taken by war into the dominant polity was a standard practice in pre-modern state formation (Koenig 1990; Chutintaranond 1995); it was an essential strategy in maintaining power and pre-eminence. On the contrary, withdrawing as far as possible from the centre of power was said to be the strategy of the wise or the desperate. The dynamic of secession-integration which has marked the relations between the ethnic minority peoples and the nation state in Burma/Myanmar since independence from Britain in 1948 could be seen as a continuation of this indigenous pattern, rather than a novel phenomenon created by the exigencies of constituting a new corporate identity for the independent state.

From this perspective, at the local level, the poverty and deprivation experienced by the indigenous ethnic minority peoples of Myanmar has been a function of the political and cultural marginality they embraced during the decades of the civil war as a means of maintaining their distinctive lifeways. Their marginality has been what Sommers, Mehretu and Pigozzi call 'systemic' (2001: 28), a product of the national political economy which resulted in Myanmar as an LDC being on the periphery of international trade and commerce, thus making it more vulnerable to the exploitation and poverty which are characteristic of communities on both national and international peripheries. They argue,

LDCs in the global peripheries have been on the receiving end of decentralized industrial enterprise. By virtue of their position of being poor and dependent, LDCs have little or no power to negotiate business deals favourable to the long-term economic development of their respective nations.

(Sommers, Mehretu and Pigozzi 2001: 25) 
As does Thomas, Sommers, Mehretu and Pigozzi (2001: 27) articulate the link between 'uneven' development, poverty and security and perceive these to be a consequence of the condition of marginality leading to community and individual deprivation: economic, political, social and cultural. The process of state creation in the modern world has itself been frequently marked by

unitarist and centralizing nation-building ideologies [which] have contributed significantly to the marginalization of some populations reinforcing old prejudices or creating new ones, inciting hostility to forms of cultural expression and social organization deemed incompatible with the preferred national ideal.

(Nolutshungu 1996: 289)

\section{'Internal colonialism' and group rights}

It is useful to employ Keal's concept of 'internal colonialism' to explore such a paradigm of power. Decolonization after 1945 often resulted in the new elites in the majority populations within the emergent nation states following policies of assimilation to compel the indigenous ethnic minority peoples within their territorial boundaries to adopt the language, customs, dress and lifeways of the majority 'settler' populations; the alternative was forced expulsion or marginalization within the political economy of the new nation state. Demands by indigenous ethnic minority peoples for self-determination, applicable in international law only to formerly 'colonized' peoples, were viewed as threats to secede and to break up the unity of the newly reconstructed nation state (Keal 2003: 45). In 1958, for example, the Shan threat to invoke the 'right to secede' after 10 years, from the Union of Burma, as agreed at Panglong in February 1947 with the late General Aung San, precipitated military action and widespread reports of egregious human rights abuses in the Shan States by the Burmese military during the 'Caretaker' government of the late General Ne Win. Painful memories from this and the earlier campaign by the Burmese military in the Shan States in 1952-4 provoked the subsequent dynamic of conflict and resistance which has been ongoing. The spectre of secession again emerged on 19 April 2005 when a number of venerable Shan elders living in exile unilaterally declared the 'independence' of the 'Federated Shan States', a formula harking back to the colonial-era administration with its implicit autonomy from centralized rule. It is noteworthy that both the central government in Yangon and the opposition National League for Democracy (NLD) denounced this 'declaration of independence' as unhelpful and divisive. This experience of 'internal colonialism' has left the bitter legacy of civil conflict in many post-colonial multi-ethnic societies which have been unable or unwilling to implement policies designed to sustain a pluralistic, multicultural society.

Keal argues, however, that the demand for self-determination by many indigenous ethnic minority peoples needs to be reconsidered; self-determination should not be equated with secession, but as the right to maintain cultural difference as 
a positive feature of indigenous peoples' lifeways and fundamental to maintaining their distinctive identities (Plates 3.9 and 3.10). Significantly, this is conceived as being attained within the parameters of the nation state in which they are located. He suggests that 'the meaning of self-determination emphasized by indigenous peoples is not of separate statehood, but control over decisions affecting their cultural survival and distinctive identities within the existing institutional structure of states' (Keal 2003: 132).

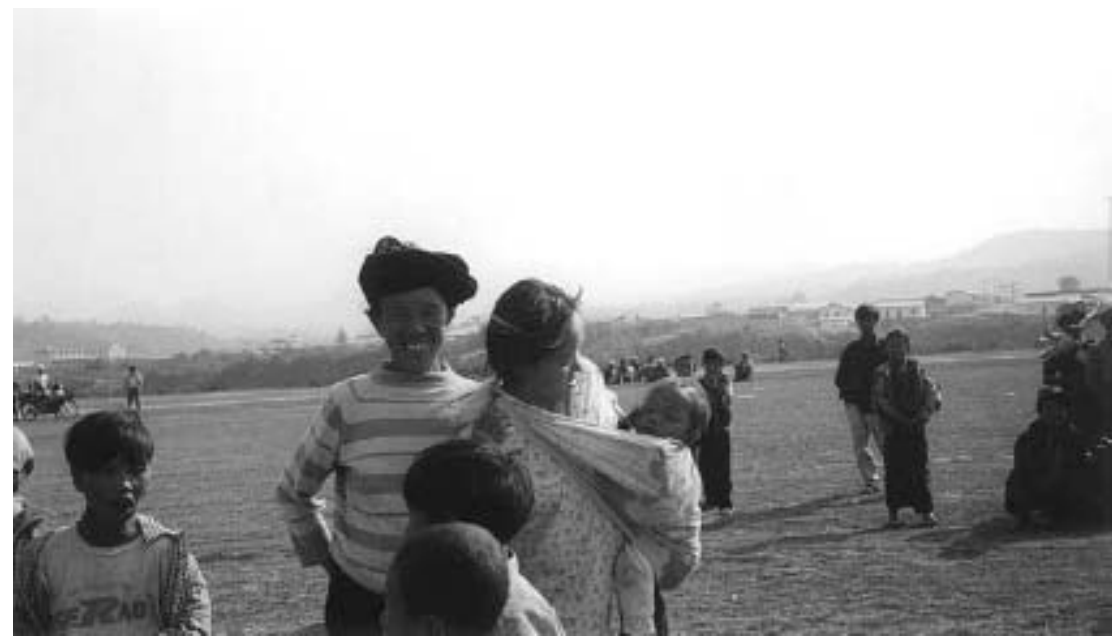

Plate 3.9 Villagers Mong Pyan (1).

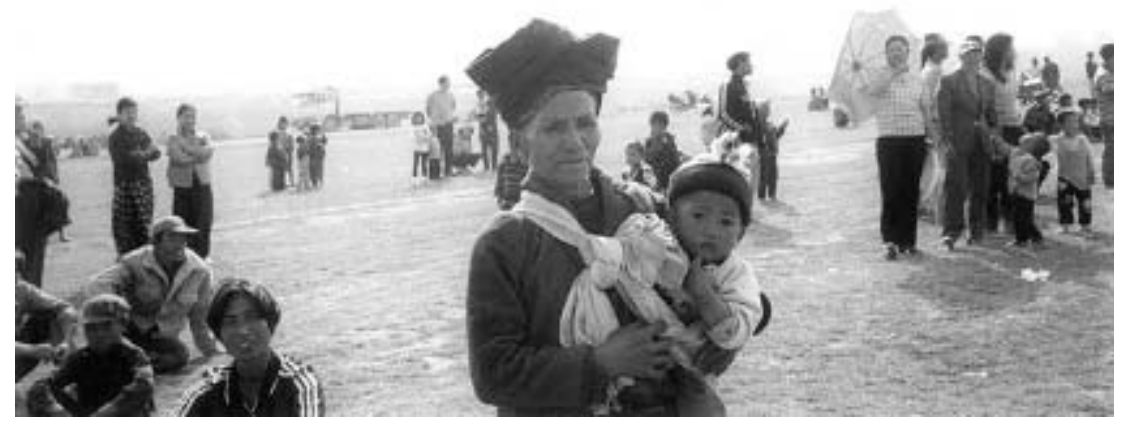

Plate 3.10 Villagers Mong Pyan (2). 
This perspective is very close to the situation I witnessed in the Wa Special Region of Eastern Shan States in February 2004 and resembles the political framework of local government exercised through local ethnic minority leaders. The cooperation between the ceasefire groups and the Myanmar government in implementing the 'right to development' - though imperfect as many human undertakings are - is nevertheless an essential component in this redefined 'self-determination' whereby the leaders of the indigenous ethnic minority peoples of Myanmar seek alternate means - other than civil conflict - for ensuring the survival of their distinctive lifeways and culture within the nation state. Such alternate means are now perceived by some of the ceasefire groups to be through embracing the opportunities for development available through the agency of the nation state. ${ }^{3}$

Curtis Lambrecht is therefore misguided in his analysis (2004: 151-81) of the relationship between the Myanmar government and the ceasefire groups. Not only does the government not 'exert control over the border regions and populace to an extent that is historically unprecedented' (Lambrecht 2004:172), but also it is clear to anyone who takes the trouble to go to these regions that government presence in the border regions, beyond the big towns, is a constantly re-negotiated entity. The Myanmar government does not have undisputed control of these areas. The indigenous ethnic minority leadership of the ceasefire groups negotiate the terms on which 'development' comes to the border regions, is implemented and distributed. Such regions are not criss-crossed by strategic highways such as those built by the US/Thai governments in North-East Thailand during the Vietnam War for express strategic purposes to facilitate transport of troops and weaponry destined for Vietnam. As one flies over the impenetrable mountainous areas of Myanmar, still largely pristine forests, such strategic highways are notable by their absence (Plates 3.11, 3.12 and 3.13). Such roads as there are, outside of the

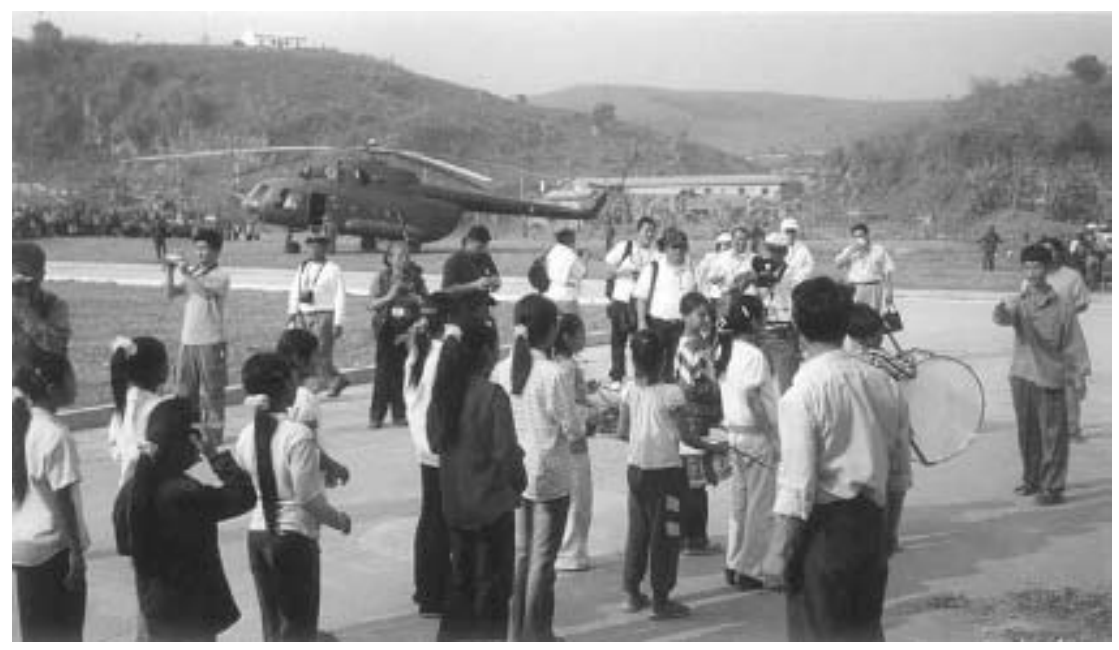

Plate 3.11 Mong Pyan welcome band, villagers and helicopter. 


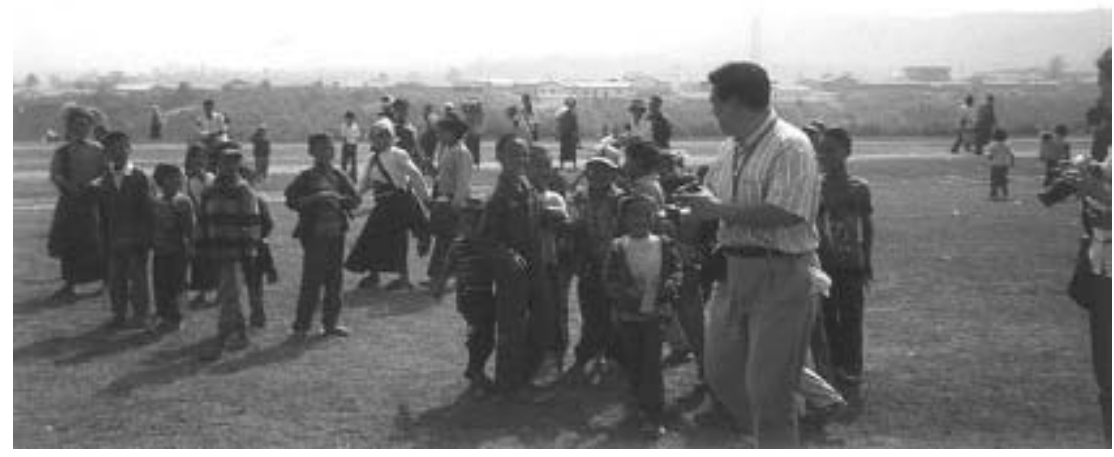

Plate 3.12 Mong Pyan truck and welcome (1).

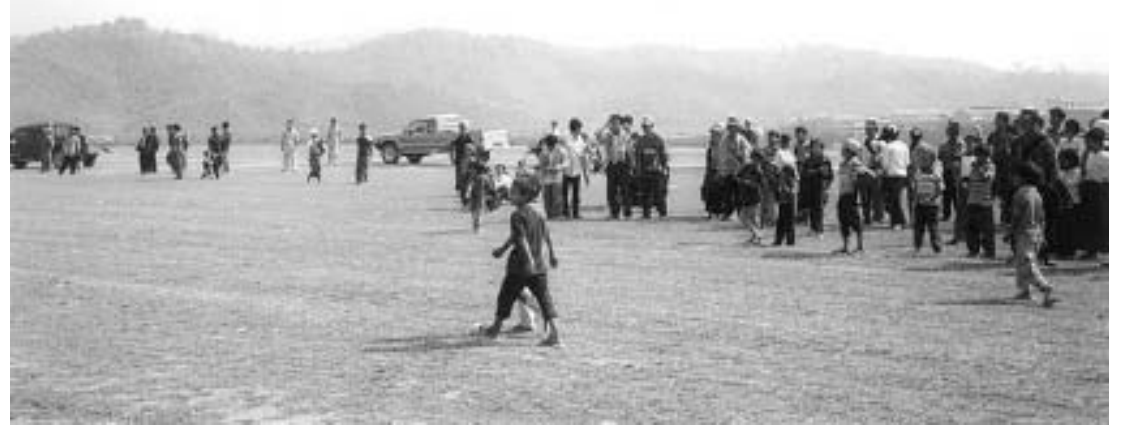

Plate 3.13 Mong Pyan truck and welcome (2).

towns and main north-south highway along the Ayeyarwaddy river corridor, are of poor quality, require four-wheel drive access, and are used mainly to transport produce to market. Many are unusable during the monsoon season, May-October. At Heho outside Taunggyi in Shan State in January 2000, I witnessed market day. Most of the agricultural produce had been brought over these unsealed arterial roads by ox-cart, some dozens of which, with their beasts of burden still in yoke, were parked behind the market stalls. At the present time, almost 50 per cent of 
Myanmar's roads are unsealed. ${ }^{4}$ Installation of a usable land transportation network in the border regions would therefore seem to be of primary practical importance in any programme to alleviate poverty in these areas; the former poppy farmers, being encouraged to follow an alternate cash crop economy, must be able to take their farm produce to market to sell it, if the poppy-replacement programme is to have any chance of being sustainable (Plate 3.14). If the infrastructure to support the alternate economy is not provided, it is inevitable the farmers will return to poppy growing to make a living. Development of the border regions is thus inextricably linked with security - of the individual and the state, and in the case of the drug trade, the wider international community.

The agreements made by the Myanmar government with the ceasefire groups are therefore the essential platform on which policies to enhance development and security can be based. As Seng Raw (2004) and Martin Smith (1991, rpt. 1999) have emphasized, this achievement has been inadequately recognized by the international community. Moreover, it has been a domestic achievement which did not receive any financial or strategic support from the international community, some of whose members actively stoked the fires of civil conflict. In the 15 years since the first of these ceasefires took effect, some measures towards Keal's view of selfdetermination within the life of the nation state have been instituted for some of the indigenous minority peoples in Myanmar. The Pa-O and Palaung, for example, as officially recognized indigenous ethnic minority groups, have been granted tracts of land in upper Myanmar outside Mandalay, under terms which could be considered to be 'self-determination within the life of the nation-state'. The 10 communities in the Wa Special Region of Eastern Shan States which I visited in February 2004 had similarly been granted tracts of land in arable valleys where rice, fruits and vegetables could be grown as cash crops, and mixed farming could

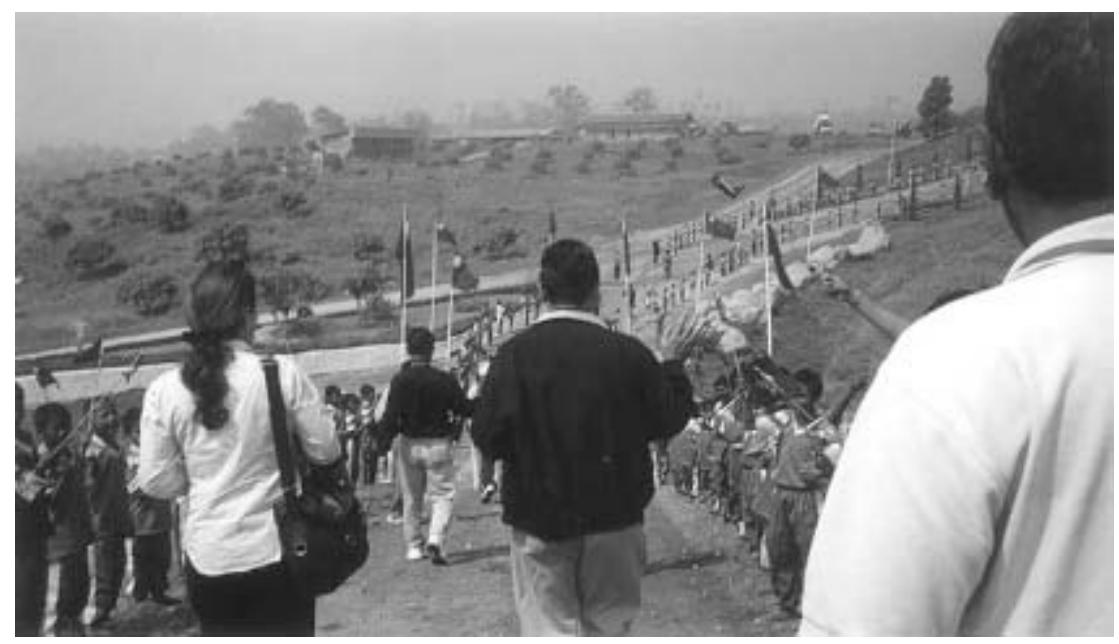

Plate 3.14 Welcome by children, Wan Hong poppy replacement project. 
be practiced, on the condition of coming down from the mountain tops where they had formerly grown poppy for a living. The irrigation networks, electricity grid and communication infrastructure which had been installed in these new land tracts were testimony to the extent of cooperation between the indigenous leadership and the government. Land rights, as Keal points out, are central to the UN's human rights regime. In the case of indigenous peoples, these are usually group or community rights deriving from their cultural mores and ties to the land. ${ }^{5}$

In the International Year of Indigenous Peoples (2003), the UN's Working Group on Indigenous Peoples (WGIP) resulted in preparation of a Draft Declaration (GA Res 1514) which 'if adopted will give indigenous peoples a "legal personality" ; and pave the way for establishing indigenous rights as new international norms (Keal 2003: 121) in the sense in which Lyons and Mayall (2003) called for international recognition of group rights within the purview of the UN's human rights accords. ${ }^{6}$ This would strengthen the new approach to self-determination by indigenous ethnic minority peoples within the life of the nation state and, theoretically, reduce the propensity for nation states to view self-determination as a challenge to their unity and security. As a state's human rights performance is increasingly being integrated into international perceptions of legitimacy, upholding the group rights of indigenous ethnic minority peoples will become an important element in a state's legal responsibility to protect both its people and its 'peoples'. Such a reconceptualization of self-determination as a group right, Keal (2003: 154) suggests, is 'vital to the development of an international civil society' which includes indigenous peoples within its purview.

The logical result of such a move would be to obviate the former disparity between individual rights and collective rights; states which abuse either would run the risk of having their 'legitimacy' challenged in the international arena. From this perspective, recognition of group rights as human rights enhances the viability of the reconceptualization of the notion of self-determination and becomes a key plank in any effective global-level poverty-alleviation strategy for indigenous ethnic minority peoples; moreover, it heightens the imperative for states which wish to be recognized as legitimate members of international society to implement policies for the improved well-being of the indigenous ethnic minority peoples within their borders. Such an approach would assist in reducing the conflict-secession dynamic between the centralizing nation state and its indigenous ethnic minorities, and contribute towards eliminating the propensity of the nation state to consider them 'enemies of the state'. The security-poverty-development nexus would thus be transformed, resulting in enhanced human security both in the border regions and the core areas of the nation state.

\section{Drug-suppression operations}

\section{Crop-substitution programmes in Eastern Shan States}

In March 2004, the tenth annual joint Myanmar-US opium poppy survey was conducted in Eastern Shan States, one of the largest poppy growing and opium 
producing areas in the world, second only to Afghanistan. Stung by international criticism and the ignominy of being identified in various publications as a "narcoeconomy', the Myanmar government had initiated a series of measures including 'Operation Hell-Flower', the 'New Destiny Project' and a 15-year plan, commencing in 1999 to rid the country of poppy. However, highly publicized seizures of drugs in the government-controlled press, their public destruction and arrests of drug traffickers failed to win the international approval the government sought. Following the March 2004 survey, however, there seemed to be some progress achieved in reducing the area under cultivation and moving towards the total elimination of poppy promised, by June 2005, by the Wa leadership in Eastern Shan States. In northern Kokang, along the border with China, the official cultivation of poppy was purportedly eliminated in 2002.

Myanmar's Central Committee for Drug Abuse Control (CCDAC) within its Home Affairs Ministry could report that the findings of the joint Myanmar-US survey team (officials from the US Counter Narcotics and Crime agency) supported a decline in poppy cultivation by 34 per cent compared with the previous growing season in 2003. This allegedly represented a decline of the area under poppy cultivation from 47,130 hectares to 30,888 hectares, equivalent to a reduction in opium production by 39 per cent - a fall from 484 tons to 292 tons of raw opium, according to Police Colonel Hkam Awng, the joint secretary of the CCDAC (first established 1975). A similar survey by the UNODC in the same period is also said to have confirmed a significant reduction both in the area under cultivation and the opium yield (Myanmar Times, 13 September 2004). To put this in perspective, Western sources estimated the area under poppy cultivation in the 1988-97 period at 180,000 hectares in total, which were said to have declined to 89,500 hectares by 2000 (said to be half that of 1997, the peak year); the same sources estimated that the opium yield for the 2002 poppy crop was 630 metric tons, 'about one-quarter the level of 1996' (Gibson and Haseman 2003: 7); at a time when annual worldwide production of raw opium was said to be 4,000 tons (Trocki 1999: 110). Myanmar government reports also indicate concerted destruction of poppy grown illegally (Myanmar Information Sheet, No. D-3018 (I) 3 May 2004) ranging from 1,500 hectares in the 2003 growing season to 7,500 hectares in the 2004 season. ${ }^{7}$

Whilst an element in this marked reduction may have been the adverse drought conditions affecting the poppy crop, there is also no doubt that the cooperative measures launched in conjunction with the Wa-Kokang leadership, the prevailing conditions of comparative peace, and international financial assistance particularly through the UNODC and neighbouring countries, Thailand and China, have played a significant role. Although it may be true, as Lambrecht (2004: 169) asserts, that such poppy reduction and eradication measures are greeted with scepticism in certain international quarters and that 'Government officials are also involved in the drug trade' - as indeed they are in many other countries (including Western countries) also - there is no doubt that the poppy reduction and eradication programme is a high priority for the Myanmar government and its neighbours, China and Thailand. It is also very significant that the success of 
these measures is viewed by the Myanmar, Chinese and Thai governments as a product of the participation by the indigenous ethnic minority leadership; the programme is not a 'top-down' policy implemented solely by the authority of the central government, but a practical exercise in participatory development undertaken with the active cooperation and support of those directly involved in replacing the poppy culture with a standard agricultural ecology.

At Wan Hong and Yong Kha, in the Golden Triangle in February 2004, I witnessed the results of some 5 years of this crop-substitution programme. Here, 'model villages' have been established with funding support from Thailand (Plate 3.15). The former poppy farmers, through the agency of their ethnic minority leadership, had been brought down from the mountain tops where they had previously grown the poppy, to a fertile valley, well-watered, which now supports a stable, mixed-farming economy based on vegetables, fruits, rices, poultry, pigs, nuts and pulses. A hospital, school and electricity infrastructure have been provided in what has been made into a very attractive environment, the results of 5 years of hard work, planning and cooperation (Plates 3.16-3.21). The first couple of seasons, after being brought down from the mountain tops, must have been very hard indeed for the former poppy farmers, uprooted from their usual homes and transplanted to this new location where they had to develop an entirely new economy. This phase of the transition cycle is presently being implemented in the northern Kokang region along the border with China, where donations of food and salt are essential to sustain the people during the transition phase. There was a view that if the political and social priorities were eradication of poppy, then there was no alternative: limited resources precluded the provision of costly infrastructure on mountain tops, not to mention the detrimental impact on the environment in such a location.

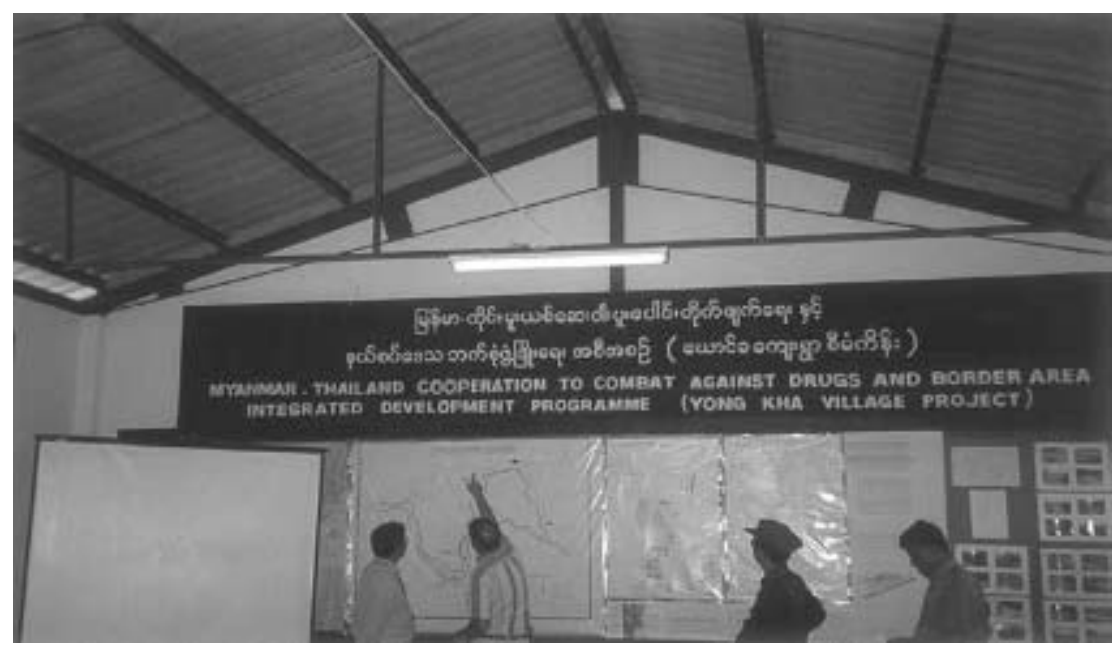

Plate 3.15 Yong Kha village project. 


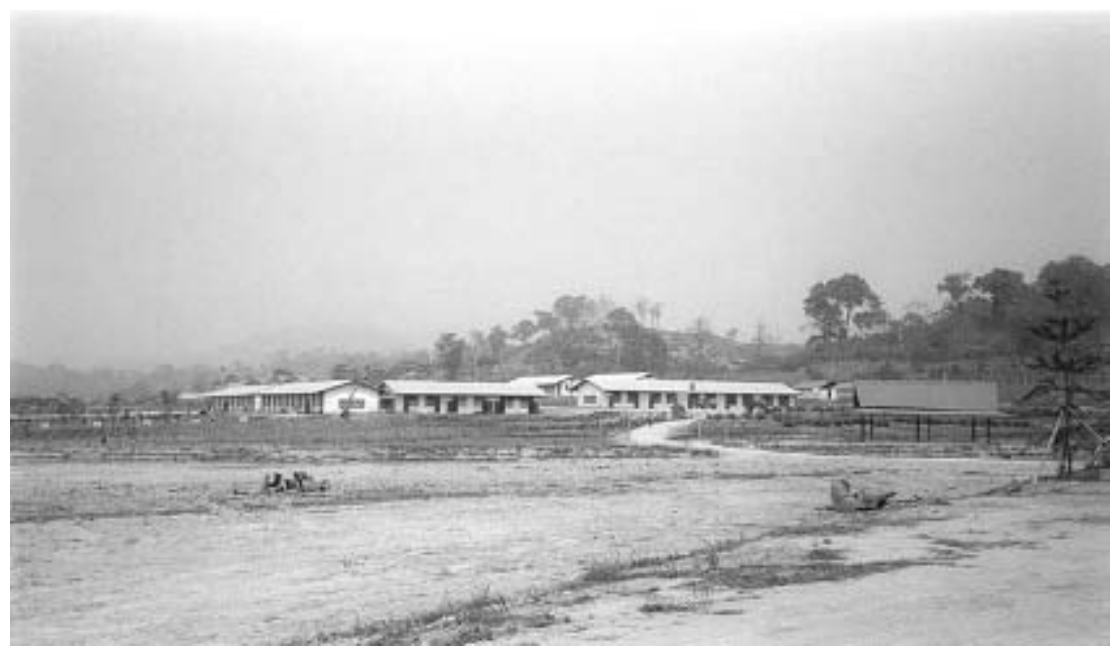

Plate 3.16 Yong Kha school and market gardens.

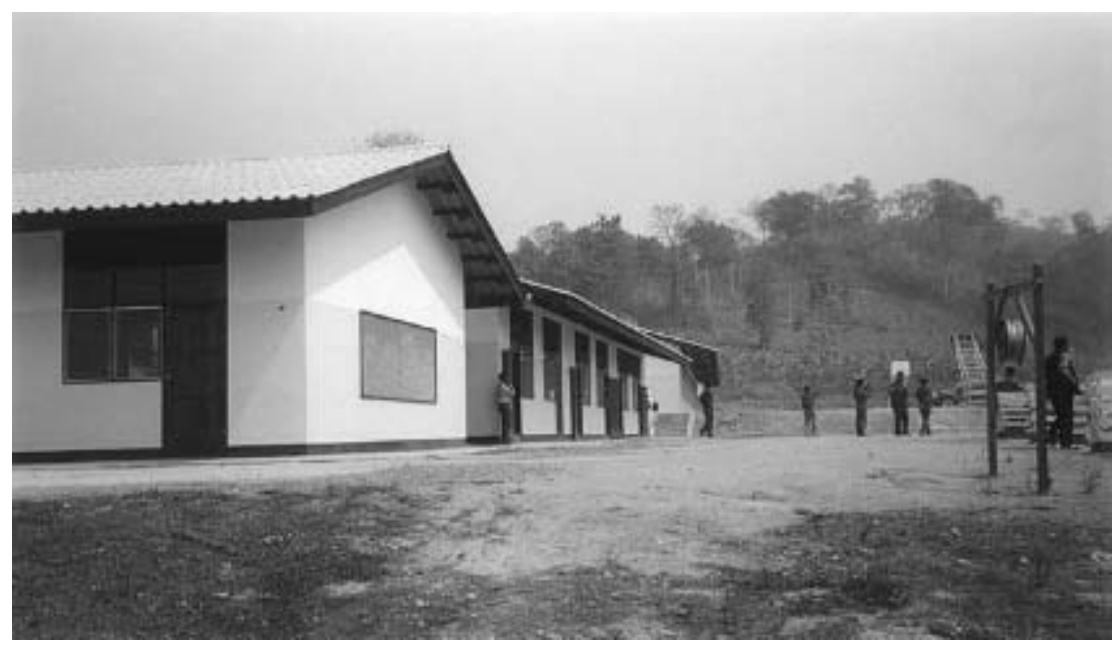

Plate 3.17 Yong Kha school and school bell made from wheel hub.

There is no doubt that all the players are conscious of the hardship involved in accomplishing the changeover to a non-poppy economy, with government sources frequently reporting on the distribution of free rice, salt, agricultural seeds, livestock and household items to the former poppy farmers who have handed over poppy seeds and participated in the crop-substitution programme (Myanmar Information Sheet No. D-3018 (I) 3rd May, 2004). Following the March 2004 


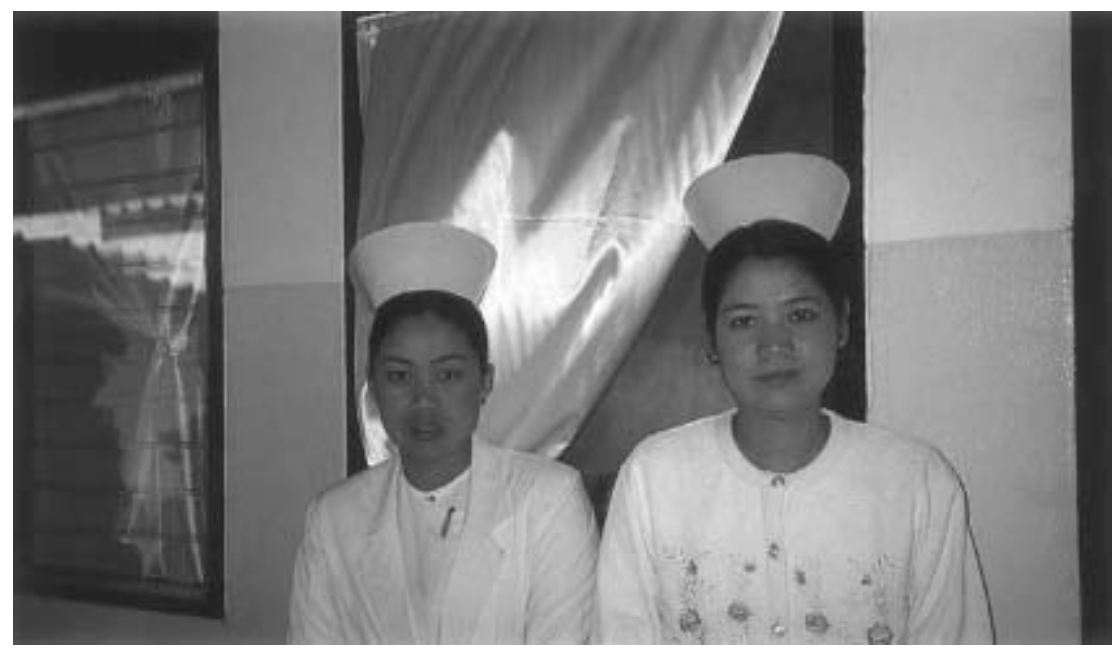

Plate 3.18 Nurses Yong Kha hospital.

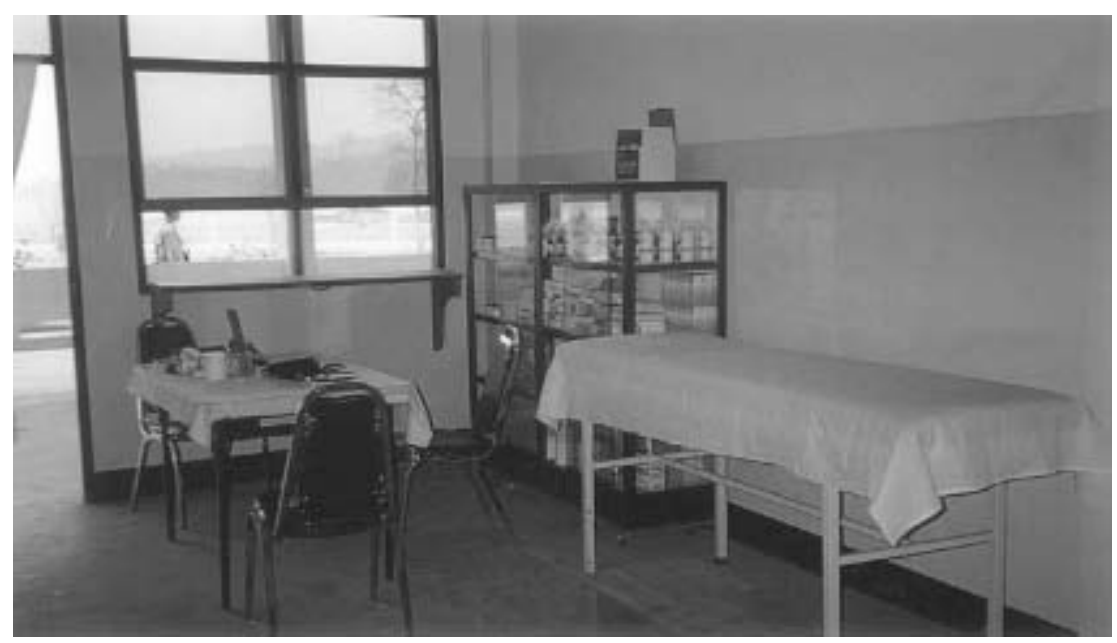

Plate 3.19 Patient examination room Yong Kha hospital.

opium yield survey with its apparently satisfactory results, it was reported that Thailand was providing further funding of 30 million baht (or about USD 700,000 on top of the 40 million baht - USD 960,000, already invested in the crop-substitution programme) for additional poppy substitution and infrastructure projects in villages outside Yong Kha in south-eastern Shan State (Plate 3.22). This two-way cooperation with Thailand, which has a significant vested interest in ensuring the interdiction of the drug trade flowing into its territories 


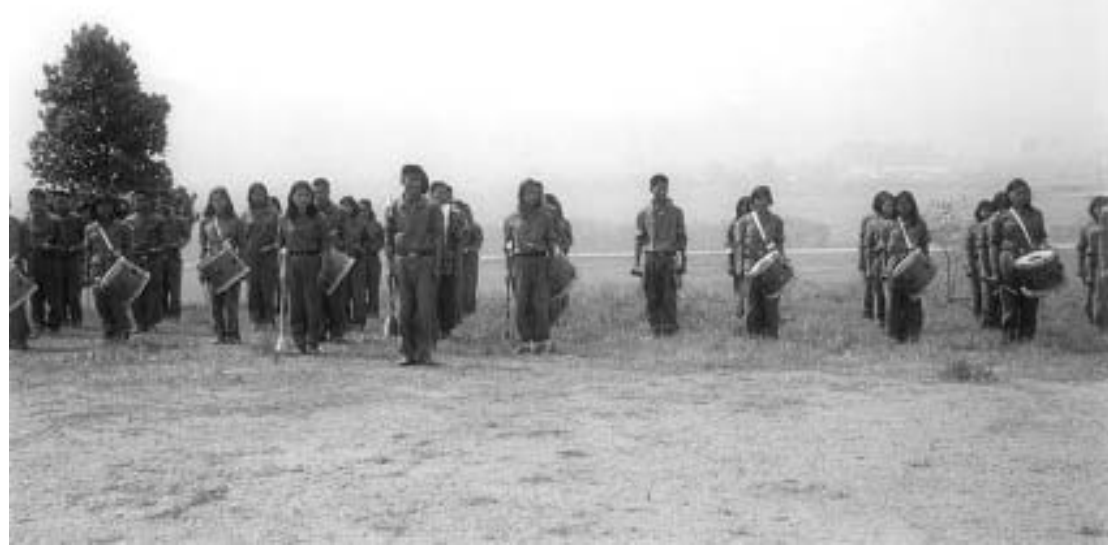

Plate 3.20 Young soldiers in the UWSA - Wan Hong welcome band.

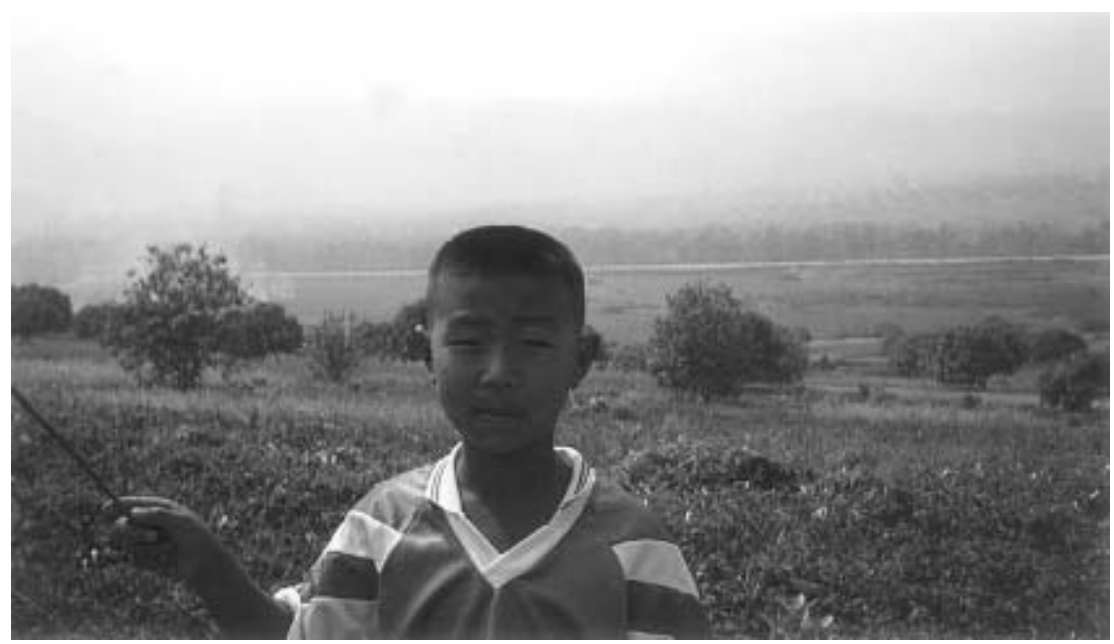

Plate 3.21 Welcome at Wan Hong poppy replacement project, showing fruit (Mandarin) trees, in background.

from Myanmar, includes provision for the former poppy farmers to be able to sell their new agricultural products duty-free across the border to Thailand. Not only is the rice deficit being addressed, but also now a surplus is available for export. ${ }^{8}$ The cross-border trade is harnessing an economic boom in the border towns such as Tachilek. Local indigenous leaders told me that the internal export, within Myanmar and around the neighbouring countries bordering the Golden Triangle, 


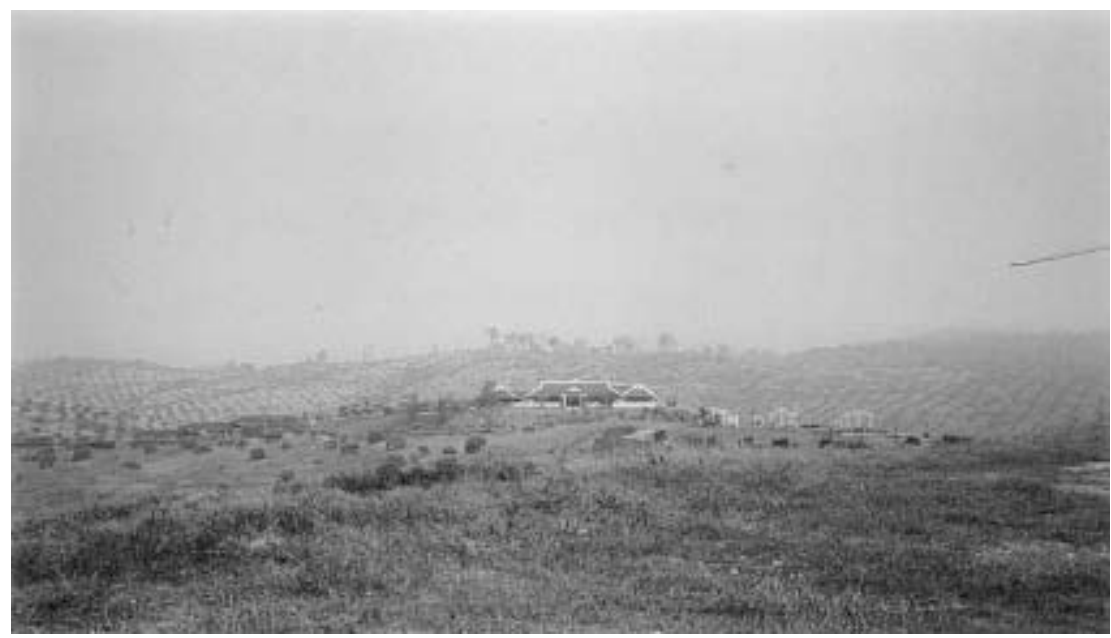

Plate 3.22 Provincial Headquarters, Wa Special Region No. 1, showing fruit orchards in background.

of surplus farm produce from the crop-substitution programmes had earned the participating communities a substantial income in the previous agricultural year.

Certainly the outlook for the children in this village seemed considerably better than in those further north where the crop-substitution programme was just commencing. Food security was being enhanced - the people now had food all year round, instead of merely the 6 to 7 months of the year previously when their economy was based solely on poppy farming - and improved access to education and health care, transport and communications infrastructure held out the prospect of greater socio-economic security. Personal and community security were not only significantly improved since the implementation of the peace accords, but also the ceasefire groups for the first time in 50 years were becoming part of a legal international economic network which was beginning to deliver them the anticipated benefits of greater local autonomy and control over their distinctive lifeways. This does not mean that the poppy economy has been totally replaced, or that illegal growing, harvesting of opium and production of illegal drugs does not continue; but that the first necessary steps have been taken to provide the former poppy farmers with an alternate economy which holds out the possibility of gradually reducing the supply of the drug. In March 2004, Jean-Luc Lemahieu, Country Representative, Yangon, for UNODC, called on the international community to provide another USD 26 million to sustain the alternate income and community development projects in (Plate 3.23) the Kokang and Wa regions of Shan State (Myanmar Times, 8-14 March 2004). Without such assistance, he warned, poppy farmers would be hard-pressed to make a living in the transitional phase of the crop-substitution programme and would be likely once again to face a food deficit. 


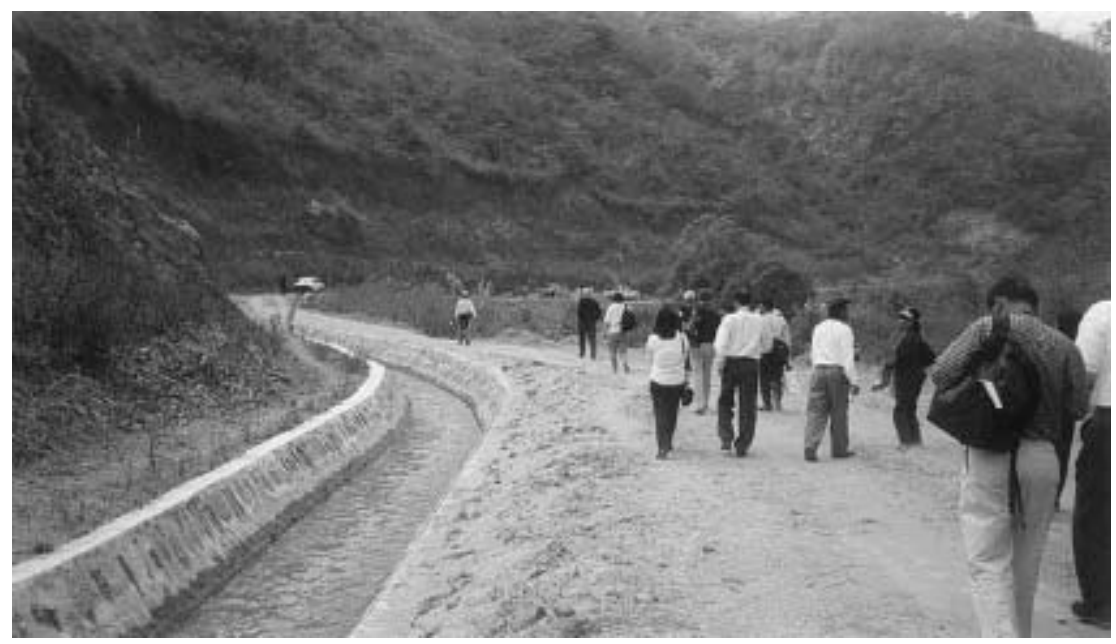

Plate 3.23 UNODC funded water viaduct for rice fields - Mong Ka.

Provision of the necessary infrastructure to support the economic and social transformation in these border regions has therefore been an essential policy initiative. Recognition of the impact of infrastructure-provision strategies in promoting pro-poor growth and the significance of interweaving national and sub-national relationships with initiatives taken in the international community were key aspects of the discussions at the World Bank's seminars on 'Poverty Day' October 2003 when it was acknowledged that such an approach contributes to realization of the Millennium Development Goals. From this perspective, the policy initiatives by the Myanmar government, through the CCDAC and the Ministry for the Progress of Border Areas and National Races and Development Affairs, in cooperation with the leadership of the ceasefire groups, are consistent with policy principles for effective poverty alleviation espoused by this key international agency.

\section{Burma/Myanmar in the international drug trade}

The Wa-Kokang regions of Eastern, Northern and Southern Shan States, usually referred to as the 'Golden Triangle,' ${ }^{10}$ host over 16 indigenous ethnic minority groups. They include the Lahu (Plates 3.24 and 3.25), Lisu, Akha, Meo (or Hmong) in addition to the Wa, Shan and Kokangese. Early in the British colonial administration of these border regions, James George Scott, C. I. E., then Superintendent of the Northern Shan States, in 1897, wrote, 'The Lahu and Akha smoke opium because [they claim] it is the best thing for their health they know of' (Scott MS U.L. 1.5-1.6). ${ }^{11}$ Over a century later, Andre and Louis Boucard, touring these regions in the mid-1980s, observed the cultivation and smoking of 


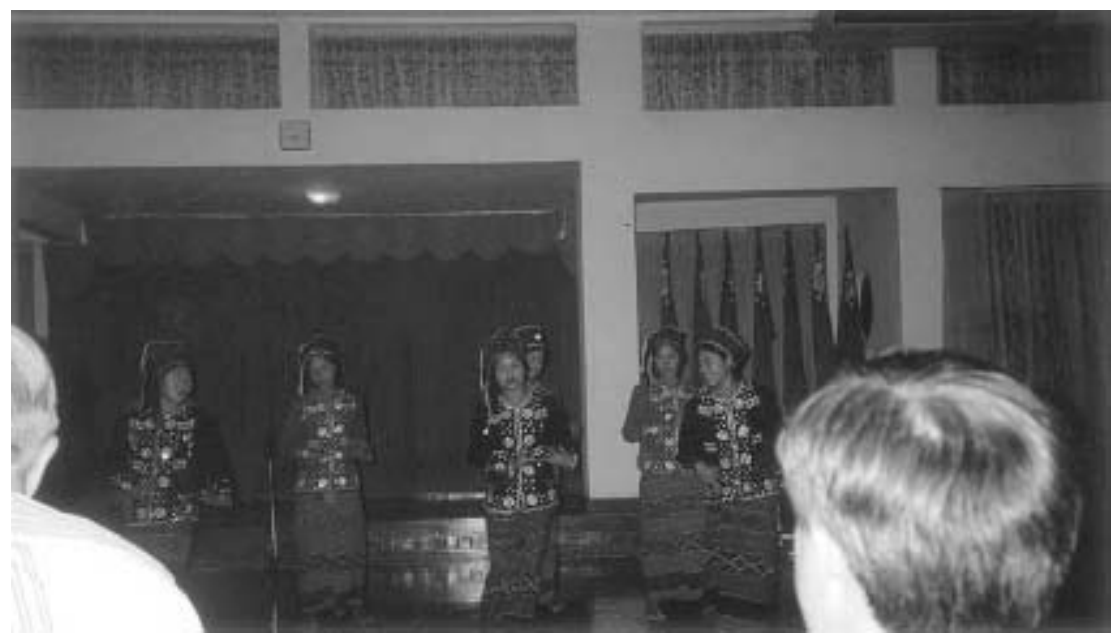

Plate 3.24 Lahu dancers Kengtung hotel (1).

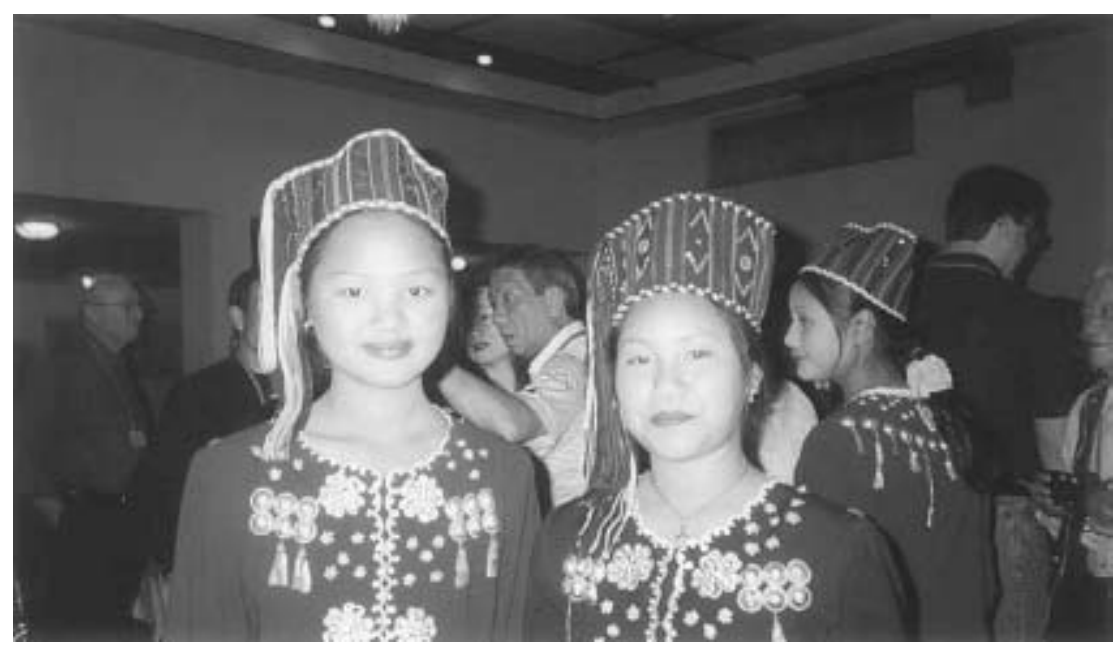

Plate 3.25 Lahu dancers Kengtung hotel (2).

opium among the Lahu, Lisu and Akha. They commented that the Lahu, of whom about 20,000 were then in Thailand, had migrated secretly from southern China and Burma, and were heavily involved in the drug trade. 'The Burmese army and Lahu are ferocious enemies and engage in merciless combat' (Boucard and Boucard 1992: 32); the Akha, an animist group with a strictly patriarchal social organization, practice 'poppy cultivation as one of their major activities' (ibid.); whilst the Lisu have long been associated with poppy cultivation as witnessed by 
the missionaries, J. O. Fraser (Fraser of Lisuland) (Taylor 1944: 43, 139, 159) and John and Isobel Kuhn (1956). Boucard and Boucard describe the following scene:

In one of the fields we visited, Alima, a stunning Lisu, was supervising the work of her companions. She was married to a wealthy trafficker and enjoyed the privilege of not collecting the opium herself. The others would harvest opium from the end of January until mid-March. Large balls of opium stuck to their spatulas. They would wrap them in flower petals to scent them before returning to the village at the end of the day.

(Boucard and Boucard 1992: 38)

For these hill-tribe peoples, cultivating the opium poppy was an intrinsic part of their everyday lives.

Although the opium poppy has been cultivated in other areas of northern Burma/Myanmar in the Hukawng Valley of Kachin state, and in the Naga regions along the Indian border, it is the Wa-Kokang regions east and west of the Salween river which have been recognized to produce the highest grade of raw opium (from which heroin is made) which meets the requirements of the international drug trade. ${ }^{12}$ The opium poppy has been cultivated here for over a century, brought by Chinese Haws (Panthay Muslims) from Yunnan, fleeing the retribution of the central Chinese government after the collapse of their rebellion in 1873. The final battle in that conflict was fought at Taw Nio, the main market in Kokang. In 1875, the Haws established the town of Panglong, where, without land rights, they became traders. When J. G. Scott was again exploring this region as a member of the Burma-China Boundary Commission in 1899-1900, he wrote,

We were now entering a land of famine, the difficulties of obtaining food having steadily increased since leaving Muang La. Here, already, we were unable to obtain either fruit or vegetables, but we were destined to fare worse later on. Opium is imported by the Ho [i.e. Haw, the Panthay Muslims] caravans, salt comes from the fields in the district, and iron from a mine near the sources of the Nam Ko, worked liked [sic] the lead mines by Khamus, who pay revenue to Luang Prabang.

(Scott MS U.L. 1.9)

The conditions he witnessed remained substantially unchanged until very recent times. During the colonial era, these regions, governed indirectly through their own leaders, were permitted to continue to cultivate poppy. Serious regulation of the trade was not attempted until the post-Second World War independence era, and particularly the advent of the military government in 1962 .

In approaching the role of Burma/Myanmar in the international drug trade, it is necessary therefore to distinguish between Upper and Lower Burma/Myanmar because diverse policies and historical developments impacted on the two areas in different ways with differing consequences for the national destiny. Since the Wa-Kokang areas have been historically the core of the opium poppy cultivation 
in Burma/Myanmar, policies to reduce the supply of drugs have been concentrated here by means of the integrated development projects discussed earlier. It should be emphasized, however, that this approach is a product of contemporary international development policies and the pressures brought to bear by the international narcotics suppression regime which has developed since 1906, and particularly since the Second World War. During the high colonial era of the nineteenth century and even in the early years of the twentieth century, these areas which produced the best opium were specifically exempted, by the British colonial administration, from the developing legal machinery of drug control. As several writers have noted (Renard 1996; Farooqui 1998; Wong 1998; Trocki 1999) both the colonial administration in India and the British home government were addicted to the revenue derived from the opium trade, which, as John Wong (1998: 27) has emphasized, indirectly, through the levy on imported Chinese tea purchased from the proceeds of the opium sales, covered more than 57 per cent of the annual cost of operating the Royal Navy. Until the end of the Second World War, and the advent of the independence era in Burma/Myanmar, cultivation of the opium poppy in the Wa-Kokang regions was not only unregulated, but positively encouraged. Attempts to regulate the drug trade in these northern regions were only undertaken after 1948, first by the late Prime Minister $\mathrm{U} \mathrm{Nu}$, then in the post-1962 era by the late military dictator, General Ne Win. The problem was, that in the independence era after 1948, the Burmese/Myanmar government in Yangon did not have effective control over these northern regions, so edicts against the drug trade were little more than symbolic expressions of disapproval.

The crop-substitution programme implemented in a systemic way since the ceasefires took effect in the 1989-98 period is perforce a comparatively recent initiative which has the advantage of being able to benefit from lessons learnt during the past 30 years when neighbouring Thailand has experimented with various approaches to development amongst the similar poppy-growing peoples living in northern Thailand (Renard 2001). Whilst Renard, a supporter of the poppycrop-replacement approach, could nevertheless express caution about the long-term viability of the projects in Eastern Shan States, Kengtung, Tachilek and the WaKokang regions (Renard 1996: 87), ${ }^{13}$ he categorically asserts that there is "no proof that the top government [i.e. Myanmar government] leaders are personally involved in the drug trade'; however, this 'does not apply to the lower ranks of the military' (Renard 1996: 106). Gibson and Haseman (2003: 3-4) agree 'officials of both the U.S. Department of State and the Drug Enforcement Administration (DEA) have confirmed to the authors what they say publicly - they know of no evidence to support charges of state-sponsored drug trafficking in Myanmar'. Such clarity does not, however, extend to the autonomous regional military commanders (said to have amassed large personal fortunes) where 'the potential for collusion between the security forces and drug traffickers is particularly strong' (Gibson and Haseman 2003: 4). The type of local level collusion described by Lintner (2000) whereby officials in the border regions (Plate 3.26) implicitly 'turn a blind eye' to drug trafficking activities in return for 'gifts' of expensive furniture and foreign alcohol is totally credible, indicative of the 


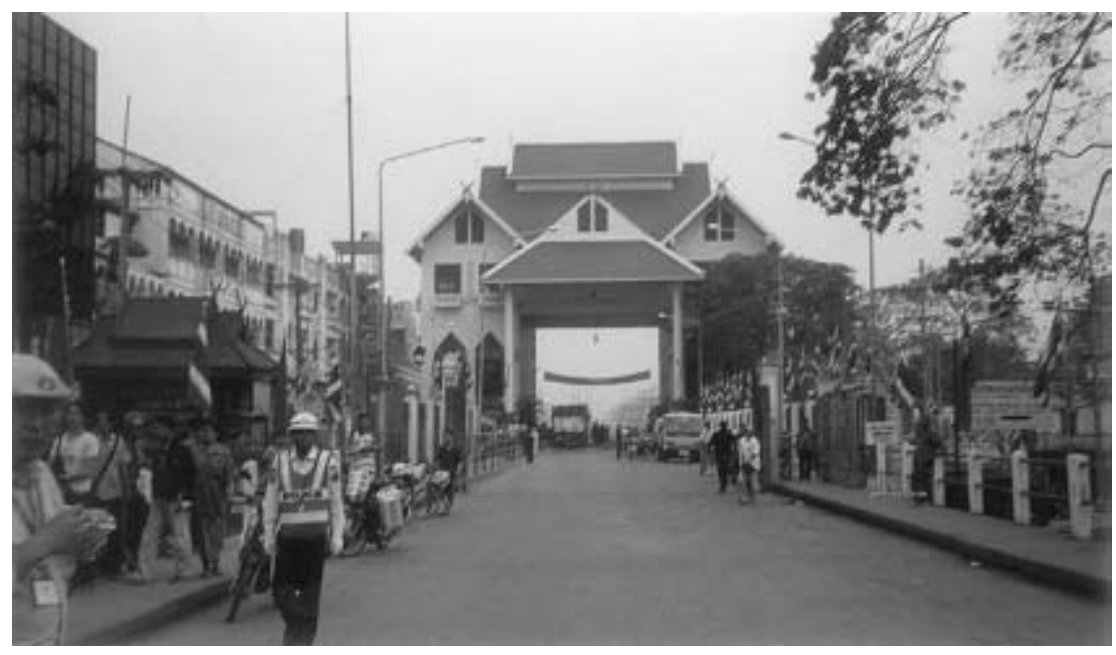

Plate 3.26 Tachilek-Mae Sai Border Gate, Thai-Myanmar Border.

systemic corruption which has been one of the legacies of the decades of civil war. In Taunggyi, Shan State, in early 2000, I witnessed a transaction taking place in the dimly lit foyer of the government hotel where my delegation was staying. That it was a clandestine transaction was obvious from the furtive glances and body language of those involved, a transaction which, for our own safety, we pretended not to see. Describing the overseas connections of the drug operations in Upper Myanmar, Lintner writes,

Historically, local merchants, mostly of ethnic Chinese origin, bought opium and sent it down to the Thai border. Shan, Kachin, Lahu, Wa and other indigenous ethnic rebels, who controlled most of northern Burma, taxed opium growers and the drivers of convoys who passed through their territory. Officers from the Burmese government's army, who were supposed to fight the rebels and suppress the opium trade, happily looked the other way if bribes were offered. But this was only 'tea money', and usually consisted of small amounts of cash, fancy furniture from Thailand, golf clubs, and foreign liquor... The real money was made when the drugs entered the Thai frontier, where the opium was refined into pure 'number four' heroin, and shipped on to the drug markets in Southeast Asia, Australia, North America, and Europe. The refineries were owned and operated by ethnic Chinese crime syndicates that collaborated with local warlord armies... Profits from those operations were laundered in banks in Thailand, Taiwan, Hong Kong and Singapore, and reinvested in often legitimate businesses such as hotels, real estate, department stores, and similar operations which showed an almost undetectable fast turnover.

(Lintner 2000: 164) 
This snapshot of the international dimensions of the drug trade, has focussed on its 'downstream' consequences and distracted attention from the need for policies to interdict the cultivation and production of drugs at their source in the northern border regions. It also overlooks the need for innovative socio-economic policies and political initiatives which will both reduce the demand for the drug and provide for effective enforcement measures. No friend of the Myanmar government, Lintner yet readily admits that 'Not a single insurgent group in the jungles of Burma had the international contacts that were needed to distribute tons of heroin world-wide, to launder millions of dollars in banks in Singapore and the Cayman Is, and to hire couriers in Amsterdam, London and Lagos' (Lintner 1994: 259). Without the international networks, the opium poppy farmers in the Kachin and Shan hills and along the Cis- and Trans-Salween states in the Wa-Kokang regions, may have continued on as they had prior to the Second World War, small scale, some eating the opium, others smoking it, using it for ritual and medicinal purposes in the treatment of diarrhoea, malaria, typhoid and cholera, without taking the step towards heroin production and other synthetic drugs. ${ }^{14}$ As Lintner asserts,

Yunnanese traffickers with direct access to people such as Khun Sa [drug warlord] and General Li [KMT general] were responsible for smuggling opium from northern Burma to the heroin refineries along the Thai border, [but] it was the Chiu Chao [i.e. Chinese] syndicates who financed and controlled the major heroin shipments destined for the international market.

(Lintner 1994: 252)

The hill tribes grew the opium; the ethnic insurgents in Shan State transported it; the Yunnanese Chinese taxed it and the Chiu Chao Chinese bought and exported it, mostly through Thailand, with the connivance of the Thai authorities and the Sino-Thai business community. ${ }^{15}$

When Andre and Louis Boucard travelled through these poppy growing regions of Upper Burma/Myanmar in the mid-1980s, foreign assistance with drug-suppression operations and poppy-replacement programmes was still being received. They reported,

A portion of the opium produced is consumed by tribesmen. The balance is bought by drug traffickers, mainly Chinese Haw [i.e. Panthay Muslims], who live on the mountain slopes and act as middlemen between the town Chinese and the hilltribe peoples. The Haws barter: they exchange opium for essentials like salt, sugar, fabric, and light industrial products such as flashlights and watches. The locals buy these, run up debts and then have to plant even more poppies. One thing is clear: rather than being the root of insurgency, drug trafficking merely provides the means by which the insurgents make a living.

(Boucard and Boucard 1992: 22)

That international assistance with drug-suppression operations was curtailed in response to the 1988 civil violence in Myanmar is a misfortune, an example of 
policy confusion and knee-jerk reaction by the international community, rather than a carefully thought-through approach to the problems of the country. ${ }^{16} \mathrm{~A}$ persuasive case could be made for suggesting that the upsurge in opium production in the 1990-6 period could be traced to this reduced capacity within Myanmar to enforce drug-suppression operations. The fact that some members of the international community are again contributing through the UNODC and through bilateral arrangements to programmes designed to reduce both the supply and the demand for drugs, as well as the enforcement side of drug suppression, is perhaps a measure of the recognition that poverty alleviation amongst the peoples of the poppy cultures has far-reaching implications for global security. As a result there is greater recognition by some international agencies that policies to improve the well-being of the indigenous ethnic minority peoples in the Golden Triangle should be disentangled from those designed to bring about civilian rule in Myanmar; in the long run, empowerment of the indigenous ethnic minority peoples must have political as well as socio-economic dimensions. It is only too obvious that no solution to the issue of returning Myanmar to democratic civilian governance will be practicable without empowerment of the indigenous ethnic minority peoples within a pluralistic, multi-ethnic framework.

Boucard and Boucard not only recognize the different administrative and legal regimes applied to Lower and Upper Burma/Myanmar in historical and recent times and what this has meant for the increase in poppy cultivation in the northern regions since the Second World War, but also they distinguish between the different poppy growing areas of Upper Myanmar - those east or west of the Salween; the Wa-Kokang regions, Kachin state and the Hukawng valley and Southern Shan State. Thus, until 1945, poppy in Kachin state was grown only in the Hukawng valley, was of poor quality, and not sought after by the international drug syndicates (Boucard and Boucard 1992: 24), in contrast to that from the Kokang region which was recognized as producing the highest grade of opium from which 'number four' heroin was made. Boucard and Boucard attribute the upsurge in poppy cultivation in both Kachin State and Shan State to the parallel increase in insurgencies in the early 1960s following the military takeover by the late General Ne Win on 2 March 1962. Government policies at the time, particularly the Four Cuts policy, ${ }^{17}$ the demonetizations and socialization of the economy both stoked the insurgencies and precipitated the increase in poppy cultivation.

Their views accord with those of Smith (1991, rpt. 1999) and Lintner (1994) who have detailed the story of opium and insurgency in the border regions since 1948, and its direct links to the rise of the Burmese Communist Party (CPB) which took over Kokang in 1968. Here, some of the fiercest battles of the Burmese civil war took place. So, although it is true that between 1886 when the British took over Upper Burma, and 1948 when Burma regained its independence, large caravans from Yunnan (where it had become the dominant crop after 1875) protected by armed soldiers, would bring the drug illicitly into the northern regions of Burma, Thailand and Vietnam, 'there was no large-scale production [of poppy] in the Triangle region before the 1940s, since Burma (under British rule), Siam and French Indochina deterred the hilltribes from cultivating poppy in order to 
preserve their own monopolies' (Boucard and Boucard 1992: 26). The poppy brought by these traders, or grown by the migratory hill tribes moving out of southern China into the northern border regions of neighbouring countries throughout the nineteenth century, was mainly for local consumption until the post-Second World War period and Cold War regional security politics changed the balance from opium for local consumption to heroin for international export.

In this changing dynamic, the Kuomintang (KMT) incursions in Upper Burma (1950-61) encouraged by the CIA and US foreign policy specialists supportive of Taiwan (McCoy 1991, 3rd rev. edn 2003; Smith 1991, rpt. 1999; Lintner 1994; Renard 1996) saw opium become the currency of the north, purchasing weapons, equipment and manpower, in quixotic attempts by remnant Chinese Nationalist bands to dislodge Mao's communists from mainland China. ${ }^{18}$ In 1961 the 'Mekong Operation' launched by Chinese premier Chou En-lai, possibly with Premier U Nu's tacit consent, saw the PLA cross the border and resoundingly defeat the KMT troops entrenched in Kokang. Subsequently, some 4,200 of the KMT's 10,000 strong force, were repatriated to Taiwan; the remainder stayed in their strongholds along the Burma-Thai border, 'well-protected by the CIA and the Thai army for their anti-communist buffer role, but increasingly financing their activities in the Shan State with opium, jade, arms and other black-market trafficking' (Smith 1991, rpt. 1999: 189).

The dynamics of opium production in these northern regions on the threshold of the twentieth century were accidentally witnessed by James George Scott, C. I. E., then Superintendent of the Northern Shan States, during his 1897 tour of the Wa states. He wrote in his diary,

The Wa seemed in danger of forming the opinion that when we came to the country we either walked through it in a great hurry, paying for everything, told them to be good, and not fight with one another, or made a sudden raid, with no very apparent cause, burnt a lot of villages and retired with equal precipitation to the unknown distance of Lashio. The Chinese, on the other hand, came up, killed all the pigs and smoked all the opium [italics mine] - two easily comprehensible and entirely convincing facts, especially when there was no hint of payment - and then tranquilly went back again to the hills which could be seen with the naked eye on the other side of the Nam Hka.

(Scott MS U.L. 1.6, Burma Political Department, Report dated 1 June 1897, Tour to the Wa States, and Chinese border)

Scott had been investigating rumours of an anti-British confederation of five Wa states. Despite orders to tread softly and warily, and basically leave the fearsome Wa alone, Scott determined that there was some substance to the rumour, burnt villages which opposed his column, and brought the Wa states, both friendly and hostile, within the scope of the British colonial administration. ${ }^{19}$ His extensive experience in Burma and among the frontier peoples, however, convinced him 
that opium was not a menace at that time to the hill-tribe peoples' cultures. He opposed official measures to make poppy growing illegal and saw it as part of their lifestyle. By 1900, when poppy had become the dominant crop in the Wa-Kokang region, it was already spreading into south Hsenwi, west Mang Lon, and on hills everywhere higher than 1,200 metres (Scott and Hardiman 1901, pt. 1, vol. 2: 358). Scott wrote, 'There are no victims of opium in these opiumproducing districts, any more than there are in Ssu-ch'uan, where the people are the wealthiest in China and half the crops are poppy. It is only in places where opium is prohibitive in price that there are victims to opium. There, to buy his opium, the poor man must starve himself... . Where opium is cheap, the people are healthy and stalwart. ${ }^{20}$ The cultivators included the Chinese, Shan, Kachin, Palaung and Lahu, Akha, Yao and Hmong (Meo) as opium poppy cultivation followed the trade routes south into Kengtung State. Renard (1996: 29) writes, 'Opium then began to be smuggled over the virtually unpoliced border into Siam where the artificially high rates charged at government dens gave the Shan States' opium a ready market.' In Kokang, ruled by the Yang family since the 1840s, opium produced huge profits; ${ }^{21}$ the Yang family's control of the trade remained unchallenged until the changing domestic and international political scene of the 1960s entrammelled the Yangs in insurgent and Cold War politics, leading the military government in Yangon in 1962, to remove Olive Yang and her brother, Edward, from control of Kokang. The CPB and other drug warlords then moved in to fill the power vacuum.

As Boucard and Boucard suggested, the international networks trading in opium, before 1945 were supplied from the monopolies established by the former colonial powers during the nineteenth century. Most raw opium traded on these networks had come from British India, with smaller amounts from Turkey and Iran. It was transported in the ships of private companies such as JardineMatheson, Dent and Company and Russell and Company. In the countries fronting the Golden Triangle today - China, Vietnam, Thailand, Myanmar/ Burma - local rulers before the colonial era had edicts in place which made opium consumption illegal. Their opposition to opium consumption was overtaken during the nineteenth century when the colonial tide rolled over Asia; opium became the prime commodity shoring up the global economy, paying for the administrative costs of empire and the wars of imperial expansion (Walker 1991; Jennings 1997; Wong 1998; Trocki 1999). At the end of the nineteenth century, China was said to have over 15 million addicts (Jennings 1997: 5). In this global trade, Lower Burma was a pawn, a ready market for excise opium shipped from India; and in the Shan States of Upper Burma, a lucrative contributor, to the British Empire's opium monopoly. Indeed, Walker (1991) and Jennings (1997) have shown that control of the opium trade was a major contributing factor to the outbreak of the Second World War in South-East Asia, shaping Japan's strategy in China, Manchuria and Burma; and in Churchill's response and determination to deny Japan the control she sought. Japan must not get India, Churchill said.

When nationalistic, post-colonial governments commenced drug-eradication measures to free their populations from opium addiction, their initiatives ran up 
against the complexities of Cold War era regional security politics, ethnic and communist insurgencies financing their activities through the drug trade, and the rapid expansion of international drug marketing syndicates. Only Mao's China, after 1949, was able to institute a successful, if draconian, drug-eradication programme. Despite years of propaganda to the contrary, the US implicitly acknowledged this in 1971 on the eve of Nixon's visit to China in February 1972. However, since that time, the operations of the international networks operating out of northern Myanmar, Laos and northern Thailand have seen a resurgence in drug addiction in China, particularly South-West China. It has been estimated that some 80 per cent of the drugs produced in northern Myanmar and Laos are smuggled into China through such border towns as Riuli (The Irrawaddy Magazine, 3 March 2004). As a result, cooperation between China, Myanmar and the countries bordering the Golden Triangle has recently been stepped up to try to interdict both the supply and the demand for drugs. Such cooperation extends to enforcement operations and sharing intelligence, including with the agencies of the international community. Along these lines, in recent years, Myanmar has been cooperating with Australia in training programmes for officials and police engaged in drug-suppression and enforcement operations.

\section{From domestic use to international commodity}

Opium has long been an item of international commerce. It is said to have been introduced by Arab traders to India and China between the seventh and ninth centuries. ${ }^{22}$ Until the seventeenth century, it appears to have been used mainly for medicinal purposes and was taken internally. By contrast, the smoking of opium mixed with tobacco was well established in the Dutch East Indies, and Formosa (Taiwan) by the end of the seventeenth century when Engelbert Kaempfer made his voyage. According to the Chinese imperial edicts of 1729 and 1799 banning the smoking of opium and then the import of the commodity to China, this more pernicious method of usage was already widespread, particularly amongst the elite classes. Opium played a dominant role in the commercial strategy of the English East India Company (EIC) in the eighteenth century; the Company had taken over the networks of its predecessors in the East, the Dutch and the Portuguese, who in turn had taken over from the Mughal emperors in India (Owen 1934: 8-22). From 1773 during the administration of Warren Hastings as Governor of Bengal, the EIC moved to stamp its control on the Indian states, and then asserted monopoly rights to poppy cultivation in India for export in the 'country ships' of private traders to East and South-East Asia.

In China, opium became the cassus belli of the war with Britain, 1839-42. After the EIC monopoly controlling the cultivation, supply and auctioning of raw opium in India was dissolved in 1834, private traders, both British and non-British, took over the opium industry, transporting vast amounts of Indian Patna, Benares and then Malwa (grown in the 'independent' states in Gujarat/Sind) opium to China where it was still illegal. ${ }^{23}$ Farooqui (1998: 91) shows how competition from the cheaper Malwa made such inroads into the EIC's 
supply monopoly that in 1823 the Government in Bengal decided to tax the transport of the drug through EIC territory when it could not prevent the opium being smuggled out onto the sea lanes to South-East Asia and China. But this proved a failure and from 1829, the Indian traders involved were recognized as partners in the opium trade who could legally send their product out through British territory. ${ }^{24}$ Thereafter, Bombay became a major port for the export of Malwa opium to China (Farooqui 1998: 142). Family companies such as that of Sir Jamsetjee Jeejeebhoy, one of Jardine-Matheson's agents in Bombay in the $1840 \mathrm{~s}-50 \mathrm{~s}$, became exceedingly wealthy on the profits of the opium trade, endowing hospitals and other public institutions.

It was a lesson well-learnt at mid-century, when David Sassoon and Sons, a family of Sephardic Jews originally from Baghdad, emerged as the prime competitors to the established opium transporting companies. They had been shipping opium to China on their own account from at least 1834 (Le Fevour 1968: 27). They initially used Malwa opium to dominate the export market to China. Sassoons purchased the crop in advance, at source (from the Indian peasant farmers, or ryots) at rates which undercut their rivals. ${ }^{25}$ When the Chinese Commissioner Lin at Canton sought, in 1838, to implement the Imperial edicts banning opium, he confiscated 21,000 chests of opium from the foreign traders in Canton, for which the Chinese government by the Treaty of Nanking, paid compensation of USD 21 million. The good Commissioner Lin, who in 1839 had sent a letter to Queen Victoria asking 'Where is your conscience?' and urging her to stop the export of opium to China, was retired in disgrace, not for confiscating the opium, but for embroiling China in a war which she ultimately lost (Lodwick 1996: 27).

Notable amongst the private trading companies built on the profits of the drug trade were Dent and Company, and Jardine-Matheson and Company (founded 1832), which became the dominant private business enterprise on the India-China opium trade route after the former went bankrupt in 1867. William Jardine, a redoubtable Scotsman, known to the Chinese as 'iron-headed old rat', made his fortune in the opium trade, then on 26 January 1839 retired to England just before the outbreak of hostilities, which he overtly fostered from his retirement haven in Scotland. A surgeon by training, he had spent some years with the EIC before meeting up with James Matheson in India where the latter was already involved in the opium trade. Both educated at the University of Edinburgh, they initially did business as Magniac and Company before the formal establishment of the firm which bore their name. Hong Kong, ceded to Britain under the terms of the Treaty of Nanking, became the headquarters for Jardine-Matheson's eastern operations. A second outbreak of hostilities, 1856-60, which John Wong (1998) has correctly identified as 'The Arrow War' rather than a 'second opium war', opened more of China to penetration by international opium merchants and gave access to the interior of the country by foreign merchants and missionaries. By the treaty of Tientsin 1858, opium was not initially made legal in China, despite the demands of the British and other foreign merchants, including American merchants (Russell \& Co., Augustine Heard \& Co.). To achieve the desired aim of it being no longer treated as contraband, the foreign merchant 
community in Canton manipulated the treaty process so that it was agreed a tax would be imposed on opium brought into the country, thus making it 'legal' by default. John Wong describes the process thus:

The Treaty of Tientsin was signed on 26 June 1858 without opium being legalized, to the dismay of British opium smugglers in China.

In desperation, one U.S. merchant thought of an ingenious way to rectify the situation. Article 26 of the Treaty of Tientsin stipulated that the 'tariff shall be revised.' If the Chinese could be persuaded to revise the tariff in such a way as to include opium among the taxable imports, then opium would have been legalized de facto. He lobbied his minister, William Reed, to this effect, and Reed was persuaded. In turn, Reed lobbied Elgin, appealing to his lordship's 'high sense of duty', urging him to 'induce or compel an adjustment of the pernicious difficulty' and assuring him that 'in such an attempt I shall cordially unite.' The conference on 13 October 1858 , fixed the tariff to be levied on opium, thus legalizing it by default.

(Wong 1998: 413-14)

Ironically, the indirect 'legalization' of opium led to a vast increase in Chinese domestic cultivation of poppy and production of raw opium, especially in Szechuan and Yunnan in south-west China where it had been grown for the domestic market since at least the 1820s. This was a marked exercise in 'import substitution'. ${ }^{26}$ The consequent fall in profits, and competition from other Indiabased merchants such as the Sassoons, eventually led to Jardine-Matheson withdrawing from the drug trade in the mid-1870s and diversifying their business into shipping, banking and insurance. As the 'Arrow War' got underway, in 1858, the firm was writing from Hong Kong to its factor, Robertson, in Calcutta,

I have just learnt privately from Shanghai that it has been arranged by Lord Elgin and the Chinese commissioner [Yeh] that opium is to be legalized and allowed to enter the same way as other merchandize on payment of a duty of $\$ 20$ per chest. The immediate effect of this when once in force will be I should imagine to increase the demand for drug rather than otherwise - but on the other hand it will doubtless tend to stimulate the native production of the Poppy which unless the price of Foreign Opium is again materially reduced will be thus sure to come into competition with it as was the case ten or twelve years ago - It might be well therefore to warn the government of such a contingency so that they may take the necessary steps to check it in the bud should they see fit - notwithstanding what is stated above with reference to demand, I would not have you calculate upon much higher prices ruling for some time to come... our stock of Bengal drug is now again very heavy, while supplies of new Malwa will doubtless come forward freely and keep it at a comparatively moderate figure...

(Private Letter Books, J-M C9/8, 5 November 1858 , to Robertson, Calcutta) 
In 1860-1, Patna, Benares and Malwa opium were fetching Jardine-Matheson between Hong Kong dollars 1,100 and Hong Kong dollars 1,300 per chest, more than double the prices fetched for the same items in 1854. Their Private Letter Books record this monumental rise; prior to the war, the three types of opium were selling in the range Hong Kong dollars 500-600 per chest (at 133 pounds to the chest for Patna; 140 pounds to the chest for Malwa; and 160 pounds to the chest for Bengal drug) which had risen precipitately at the outbreak of hostilities. In these years, and up to 1880 , Jardine-Matheson alone imported between 2,000 and 2,500 chests of opium to China every month. By 1875 , when competition from Chinese domestic poppy and aggressive purchasing tactics by the Sassoons in India drastically reduced prices and profits, Jardine-Matheson took the decision to diversify and cease their direct involvement in the opium trade. They were correct in predicting increasing demand arising from the turbulent social conditions of the mid-century when China was beset by the Taiping and the Panthay rebellions; and had foreseen the vast increase in the domestic crop. By 1875 south-west China, Yunnan, the regions bordering northern Burma, were said to be awash with poppy blooms. Correspondence of Jardine-Matheson from Hong Kong, 19 July 1859, to George Brown, Calcutta states,

I regret that I am unable to advise any improvement in our opium market which has continued at the same dull unsatisfactory position... Sales of Bengal are with difficulty now made at $\$ 755$ for Patna and $\$ 745$ for Benares. The arrival of the Fiery Cross with confirmed accounts of the short coming in next year's supply at first caused holders to advance their rates some $\$ 10$ above present quotations, but as there was no demand for consumption they could not be maintained...

There is now no reasonable doubt that Chinese grown drug is coming more and more into favor and from its low cost say, $\$ 450$ per picul, is likely to affect to no small extent the consumption of Foreign Opium, at the present comparatively high rates. Should the range of prices in India continue excessive for any lengthened period I fear the cultivation of the Poppy in China will be so much increased as ultimately to interfere with, if not altogether exclude, opium of foreign growth. To this and the heavy duties now being levied all along the coast as well as at most of the Inland custom houses I attribute the prolonged stagnation in our market...

(Private Letter Books, J-M C9/8)

But then the drought hit the domestic opium crop in south-west China, leading to a sharp jump in demand and steep rise in prices, up to Hong Kong dollars 900 per chest by December 1860, then over Hong Kong dollars 1,000 per chest in 1861. In March 1861, Jardine-Matheson was writing to their agents in Bombay and Calcutta with great excitement at the enormous increase in the price, but with the realization that such prices could not be maintained for long and were likely to provoke a large expansion in the area of poppy under cultivation within China. Correspondence from Hong Kong to George Brown, Calcutta, on 26 March 1861 states, 
The small quantity of opium brought on by the 'Thunder' took me quite by surprise, for in anticipation of her having some 1600 chests or so, I had nearly cleaned out of Bengal drug. The excitement caused here on her arrival was very great, and prices were at one time run up to $\$ 1140$ for new and $\$ 1135$ for old Patna and $\$ 800$ per picul for Malwa. Our market is now very dull for all descriptions, nominal quotations being $\$ 1130$ for new and $\$ 1120$ for old Patna, $\$ 1115$ for old and new Benares and $\$ 785$ for Malwa.

(Private Letter Books, J-M C9/8)

This was the high tide of prices for foreign opium of Indian origin in China. Once the domestic Chinese crop recovered, prices of Indian opium dropped sharply, as Jardine-Matheson had anticipated. Their correspondence shows the decline starting by June 1861 and then going rapidly into free fall, until by 1868 they had difficulty obtaining between Hong Kong dollars 400 and 500 per picul for all three types of Indian opium, Patna, Benares and Malwa. Writing from Hong Kong, 19 October 1868, to their agent, Rustomjee Eduljee, Bombay, Jardine-Matheson state,

It is now admitted that the extension of the cultivation of the poppy in the Western provinces [of China] has thrown so great a quantity of native produced drug on the markets of the interior as to interfere very considerably with the consumption of the foreign imported [opium].

(Private Letter Books, J-M C9/9)

Similar advice was sent to their agent, Lidderdale, in Calcutta. The expansion of poppy cultivation in the west and south-western provinces of China coincided with the turmoil of the Panthay rebellion in those regions (1855-73) and the Taiping (1851-64) along the Yang-tze basin, as well as other uprisings in north west China. As John Wong (1998) notes, the social instability and insecurity in much of China in the middle decades of the nineteenth century probably contributed significantly to the rise in demand for the drug which was met by a vastly increased rise in supply at prices which the local populace could afford, and which undercut the imported item.

The expansion in poppy cultivation in south-west China also coincided with various attempts by British colonial administrators in Burma between 1855, 1868 and 1875 - Clement Williams, Edward Bosc Sladen, Horace Browne, Augustus Margary and John Anderson - to find a feasible route through King Mindon's realm of Upper Burma to south-west China, from 'Mandalay to Momien'. Writing of the 1868 expedition to Momien (Teng-yueh) John Anderson described their arrival at the beginning of May amongst the Hotha Shans of far south-west Yunnan, just north of the Burmese border.

[T] he valley from one end to the other appeared an immense watery tract of rice plantations glistening in the sunshine, while the bed of the river was left half dry by the subtraction of the water. Tobacco, cotton and opium are grown 
on the well-drained slopes of the hills, the two former for home use; but the white-flowered poppy is cultivated to supply the requirements of Chinese, Kakhyens [i.e. Kachins] and Leesaws [i.e. Lisus]. A considerable quantity of Shan opium finds its way to Bhamo, and thence to Mandalay, and also to Mogoung, whence it is distributed among the Singphos.

(Anderson 1876: 299-300)

Having forced open the ports on China's eastern seaboard, then having gained access to the interior, the British at mid-century were obsessed with finding what they called the 'backdoor' to China; they fancied that here the merchants of Manchester could find the millions eager to purchase British cotton and woollen goods which they were unable to sell elsewhere in China. Tragically, the social and economic cost of opium detracted from the Chinese capacity to buy the goods which British merchants thought they could and should purchase. ${ }^{27}$ Instead, British explorers, travellers, and later, missionaries of the China Inland Mission (CIM) saw the opium fields of Yunnan, which, after an initial attempt at eradication after the Chinese revolution in 1911, blossomed to fuel the activities of the warlords in the era of President Yuan Shih-k'ai. Peasants in Yunnan were compelled to plant poppy by those charged with eradicating it. Social upheaval and communal violence in south-west China in the 1911-16 period was so extensive that the missionaries of the CIM., J. O. Fraser and his colleagues, were advised to seek temporary sanctuary in northern Burma at Bhamo.

In Lower Burma, the story was rather different. That some form of opium consumption was present in Lower Burma during the Konbaung dynasty (1752-1886), can be adduced by the draconian edicts issued by King Bodawpaya (1784-1819) prohibiting both drugs and alcohol in the Burmese empire. Siamese kings, Rama II and Rama III, of the early Chakri dynasty (1782-) were issuing similar injunctions against opium smoking. In the mid-sixteenth century, a son of the Burmese King Bayinnaung, died from opium addiction; and the Siamese kingdom of Ayudhaya (1350-1767) had issued laws prohibiting opium consumption in the mid-fourteenth century. Opium addiction in Lower Burma only became widespread after the irruption of the EIC following the first Anglo-Burmese war of 1824-6, when Burma lost its two Indian Ocean provinces, Tenasserim and Arakan, to the invader. From 1826, the colonial administration in Lower Burma actively encouraged first the use of opium - which was given away free dipped in betel leaves to establish a taste for it - and later its spread through licensed dens and the system of registering users (Renard 1996: 25). Lower Burma in 1841 was said to have the largest number of users of any province of British India. By the time of the Arrow War in 1856, Konbaung Burma had lost all of Lower Burma after the second Anglo-Burmese War in 1852; and the responsibilities of the EIC, in 1857, had been subsumed by the British Government. Excise opium from India was then traded in large quantities to British Burma. Jardine-Matheson, with ships trading opium to Penang, Singapore and down to Australia, also traded opium from India to colonial Lower Burma through their agents, Bullock Brothers. ${ }^{28}$ This emerges in their correspondence when their ship, the Reiver, was wrecked on Preparis reef 
off the Burmese coast in 1868. To John Skinner in Calcutta, 20 October 1868, the following curt note was sent:

On the $18^{\text {th }}$ inst. I received a telegram from Messrs Bullock Brothers of

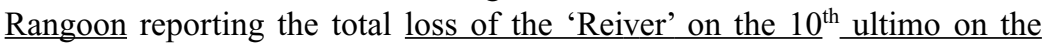
Preparis Reef. The bare fact of this great disaster is all that I know and I am very anxious for full particulars. The loss of such a steamer and cargo is a public calamity, and in the opium trade will be severely felt by many. I trust the captain and officers will be acquitted of all blame at the naval court of enquiry which I presume will be held at Rangoon. We have no particulars from you yet of the risks upon the cargo taken, or the various officers in which we are interested, but as usual I feal [sic] all lives have been taken. It is curious that the craft should have been unfortunately kept back by you, that you should have so thoughtlessly put all our opium on board of her although our other steamer was leaving within a short time of her, and that on her first voyage with a new captain she should have been lost. It is a sad misfortune.

(Private Letter Books, J-M C9/9)

Still bewailing the loss of the Reiver and its opium cargo, the company informs its Bombay agent, Lidderdale, on 2 November 1868,

The opium trade has changed from the days when a disaster like the above would have caused an important advance in price. Speculation appears to have become extinct, and the Chinese dealers now buy only to meet current consumption. The supply of native grown opium too at a low cost in the interior is certainly curtailing the consumption of Indian drug, and will continue to do so as long as the heavy imposts on the latter render the cost of its conveyance into the interior of the country so great.

(Private Letter Books, J-M C9/9)

The British colonial administration differentiated between Upper and Lower Burma not only in their administrative arrangements which applied direct rule to the core heartland areas of Burma after the Third Anglo-Burmese War in 1885, and indirect rule to the frontier areas where the ethnic minority peoples lived, but also in their international dealings. By its conquest of the remaining kingdom of Upper Burma in 1885, Britain gained access to one of the world's richest opiumgrowing areas (Renard 1996: 25). The Burmese king's prohibition on opium was abolished and The Opium Act of 1875 was extended to Upper Burma in 1886; however, the Trans-Salween states where the best poppy was grown were exempted from application of the Act. As Renard observes,

The Opium Act sanctions applied only to areas of direct control known collectively as Burma Proper... . The trade in excise opium between Burma Proper and India continued, and excise opium was legally available through 
government-regulated opium dens. However, since the cost of opium in these dens was kept high as both a deterrent and a source of revenue, the grounds for smuggling were laid. The rail lines and other transportation links built by the British facilitated smuggling from the growing regions in the north to users in Rangoon and other cities in the Burma delta. Since control over use was not implemented outside of Burma proper, and since the British lacked the means to interdict contraband successfully, smuggling grew steadily.

(Renard 1996: 25)

As the impulse to develop an international regulatory regime to control the narcotics trade developed after the 1909 Shanghai conference, British international policy on opium took evasive measures. On specious grounds, in 1923 the British colonial administration excised the main poppy-growing areas of the Trans-Salween states from the emerging international drug-suppression regime. During the Second World War, opium was used in the frontier areas of northern Burma to pay for intelligence provided by the Kachins to Allied Forces fighting the Japanese (Lintner 1990: 61; Walker 1991: 148, 162). ${ }^{29}$ At independence in 1948, Premier U Nu was conscious that he had a major problem on his hands to bring the approach to drug suppression in the frontier areas into line with that applying in Lower Burma. ${ }^{30}$

\section{Development of an international drug control regime}

Ironically and perhaps with poetic justice, the Chinese government in the last days of the Ch'ing dynasty, initiated the steps which would bring to an end the opium trade operating out of India which, as Wong (1998) has shown, sustained the expansion of the British empire. Encouraged by the 1906 House of Commons declaration that the opium trade was immoral, on 20 September that same year the Chinese government issued an Anti-Opium Edict forbidding the planting of poppy, its usage and smoking of opium. Every opium shop was ordered to register and the sale of opium lamps, pipes and smoking paraphernalia was prohibited after 6 months. The elections that year saw the Liberals take office in Britain; John Morely became head of the India Office, while Sir Edward Grey became Foreign Secretary. As Lodwick states, 'The tide finally turned in favor of the Anti-Opium movement' (Lodwick 1996: 122). A predominance of members in the new parliament were middle class and came from the non-conformist churches. Sir Edward Grey took a significant role in ending the official opium trade out of India.

On 26 January 1907, the Chinese government formally requested the British government to end the export of opium to China. On 12 August 1907, Britain agreed; the annual export of opium from India would be reduced by one tenth each year for 10 years, if China itself made corresponding reductions in its domestic crop. From the base figure of 51,000 chests provided by the Government of India, the trade was to be reduced by 5,100 chests per year. The agreement went into effect on 1 January 1908, and China launched into concerted drug-suppression operations. At the instigation of Sir Edward Grey, and with the 
blessing of the Chinese government, Sir Alexander Hosie, consul general in Tientsin, went on an inspection tour of those provinces where poppy eradication measures had been taken; he saw that in Yunnan and Szechwan a considerable degree of success had been achieved (Owen 1934: 341). Greedy opium merchants had stocked up supplies, said to be in the vicinity of 20,000 chests worth 10 million British pounds (Owen 1934: 347) on the assumption that China would not be able to meet its end of the agreement (Walker 1991). But they were wrong; they had not counted on Chinese tenacity and public opinion. On 8 May 1911, a further agreement with Britain acknowledged the success of the Chinese suppression operations and looked towards total eradication by 1917.

In the end, it was the opium merchants themselves who requested that further exports from India be curtailed. They could not sell their stocks, and the banks which had advanced some 4 million British pounds on the expectation of profitable sales, were becoming nervous of widespread business failures. In March 1911, opium belonging to the Sassoons was seized by Chinese officials at Amoy and another shipment in April that year. They complained that they could not sell their stocks (frequently uncertified opium, in contravention of the export rules). Up to this time, China's domestic crop in Yunnan, Kweichow, Shensi and Szechwan produced 250,000 piculs of raw opium per year for the estimated 15 million addicts in the country (Walker 1991: 12-14). By 1911, the year of the Chinese revolution, nearly four fifths of all opium land had been converted to food crops (ibid.) thanks largely to concerted effort by inspectors and public opinion. Walker (1991: 14) asserts that 'major exceptions could still be found' in Hupei, Anhwei, Kansu, Kweichow and Szechwan'. By 1913, it was being suggested to London that the 1908 agreement be revised owing to changing conditions in China. ${ }^{31}$ On 31 March 1917 Britain formally prohibited the opium trade from India; it became 'a criminal offense for any British subject to have an interest in opium' (Lodwick 1996: 178).

How did the opium get onto the international agenda, by what agencies, and how did this impact on Burma/Myanmar? Opposition to the opium trade on moral grounds had been building in Britain since 1843 when Lord Ashley (Shaftesbury) and the missionary societies sought to raise awareness of its pernicious effects on the populations to whom it was sold. Opium at this time was legal in Britain itself, taken mostly in medicinal form such as laudanum or as a cough elixir, and celebrated by DeQuincey in Confessions of an English Opium-Eater (1853, rpt. 1960). That Shaftesbury was not initially successful did not deter those implacably opposed to the trade; nor those equally committed to its staunch defence. By the mid-1880s when 80,000 chests (at 133 pounds per chest) of opium per year were being shipped from India to East Asia, the lines of the arguments on both sides can be seen from the following two discourses, both published in 1884: the first, by Fellow of St. John's College, Cambridge, J. Spencer Hill (1884) The Indo-Chinese Opium Trade: Considered in Relation to its History, Morality, and Expediency and its influence on Christian Missions, attacks the Jardine-Matheson position and quotes one of the company's own, Donald Matheson, who had left the company to take a leading role in the anti-opium movement in Britain. 'Our connection with the traffic is wholly unjustifiable' Matheson states. The opium 
trade is 'an unmitigated evil, positively and very extensively injurious to the Chinese' (Spencer Hill 1884: 47-8), by which 'we are still year by year doing a grievous wrong to China'. Spencer Hill's essay clearly demonstrated that the connection between opium cultivation and famines was already well documented in international discourse. He quotes Donald Matheson showing the negative impact on international commerce,

[T]he effects of the opium trade on legal commerce have been most disastrous....

In the decade between 1845 and 1855, while our exports to all countries rose from $60,000,000$ pounds to $95,000,000$ pounds, to India they fell from $2,394,000$ pounds to $1,277,000$ pounds and our imports from that country rose from 5,500,000pounds to 8,500,000pounds; and the opium import to China rose from 5,000,000pounds to 8,000,000pounds; figures which... obviously point to only one conclusion, and clearly show that, in supplying the Chinese with an intoxicating drug, we are drying up their natural capacity to consume our manufactures.

(Spencer Hill 1884: 62-3)

On the moral question, he raises the Chinese position: 'Why do the Christians bring us opium?' In China, anti-opium pills were known as 'the Jesus Opium'. Missionaries had arrived on opium clippers; and had served as interpreters to the opium merchants. Now they were leading the charge against its widespread usage. Spencer Hill states,

Dr Medhurst [London Missionary Society, Shanghai] tells us:

'Almost the first word uttered by a Chinese when anything is said concerning the excellence of Christianity is, Why do Christians bring us opium, and bring it directly in defiance of our laws? The vile drug has destroyed my son, has ruined my brother, and well-nigh led me to beggar my wife and children....'

(Spencer Hill 1884: 77-8, 87)

After 1860, the missionaries were able to provide eloquent testimony to the harmful effects, widespread use and concerted efforts in far-flung corners of China from Hopei to Yunnan, to counter addiction to the drug. From 1868, the Presbyterian Mission Press in Shanghai published the ecumenical Chinese Recorder, in which missionaries could express their views on the trade. Periodic regional and national missionary conferences also provided avenues for their voices to be heard. In 1897, Shanghai, for the first time, hosted the Anti-Opium League to which the Chinese contributed. The Presbyterian Church in England had passed resolutions calling for the abolition of the opium trade at synod meetings in 1858, 1880, 1881, 1887 and 1898.

But the opposite position was enunciated by C. R. Haines (1884) A Vindication of England's Policy with Regard to the Opium Trade, who took issue with 
'misguided Philanthropists' and whilst acknowledging the rapid spread of opium use in the Province of Burma and elsewhere among Britain's colonial possessions, professed to believe that this was due to Burmese people giving up their indigenous cultural and religious values. Citing the expressions of concern coming from Burmese community elders, Haines argues,

The Government, as a recent writer in The Times says, promptly took advantage of this feeling to close forty out of the sixty-eight opium shops, and raise the price of opium 30 per cent, at a loss to the provincial revenues of from 50,000 pounds to 70,000 pounds. No one will question the wisdom of these measures; but there can be little doubt that on the one hand the demoralization caused by the spread of the vice was exaggerated, while on the other the guilt of the Government is not so flagrantly evident, for there never were more than sixty-eight shops in 87,000 square miles of country. No one could lawfully possess more than one ounce of opium outside a licensed shop, and the law, if broken, was promptly vindicated.

(Haines 1884: 46)

Haines' arguments were typical of the specious rationales used by the proopium powers to counter the moralists' position. The view was purveyed that China wanted the opium exports from India curtailed in order to monopolize the trade herself. However, the Anti-Opium League considered the Chinese government position robust. Even at the time of the 1893 Royal Commission, some British government officials were expressing determination to continue the opium trade. Lord Kimberley, Secretary of State for India, threatened to resign rather than agree to the opium revenue from India being foregone. The Royal Commission met in London for a week in September 1893, took evidence from officials who had been in India and other British colonies, and proceeded to distort or ignore the evidence from missionaries, the anti-opium societies and the Women's Christian Temperance Union. The Royal Commission then moved to India where, between 18 November 1893 and 22 February 1894, it took evidence from people from Burma, India and other parts of Asia. It did not, however, visit China. The findings of the Royal Commission, as Lodwick notes, were a 'whitewash' (Lodwick 1996: 38) and a great disappointment to the anti-opium movement.

However, by 1909, the 'misguided Philanthropists' had achieved the first steps in the development of the international narcotics regulation regime, driven by American missionaries who were repelled both at the social effects of the worldwide opium trade and their fellow countrymen's history of involvement in that trade. In 1881, by Treaty between the US and China, Americans were prohibited from being involved in the opium trade (first engaged in, in 1805). The Shanghai International Opium Commission of 1909, which formally set the stage for international regulation of the narcotics trade, originated in the 24 July 1906 proposal by missionary Charles E. Brent, Episcopal Bishop to The Philippines, to President Theodore Roosevelt, that the US take the lead in 'promoting some movement that 
would gather in its embrace representatives from all countries where the traffic in and use of opium is a matter of moment' (Jennings 1997: 62). The 13 nations attending the 1909 Shanghai International Opium Commission (the US, Britain, Japan, China, France, the Netherlands, Germany, Russia, Austria-Hungary, Italy, Persia, Portugal and Siam) entered a series of non-binding resolutions which advocated restricting the trade in non-medicinal narcotics. Japan's participation recognized its increasing involvement in the international opium trade since 1897, despite its own 'opium free' policy since the 1858 Treaty with Townshend Harris. Over the next three decades, Japan's expansionist policies in Formosa (Taiwan), Manchukuo (Manchuria), Korea and China itself after 1937, would put it in control of some of the world's largest opium-producing areas, a role which earned it an undesirable place in 1945 at the International Military Tribunal for the Far East (IMTFE), where those considered responsible for using opium as a strategic weapon to undermine the health and morale of the Chinese people (Jennings 1997) were prosecuted as war criminals. That Jennings (1997) and Walker (1991) have both investigated the charges and come to the conclusion that Japan was demonized as a drug empire during the interwar years because this served American and British foreign policy interests highlights similar approaches to China after 1949, when evidence suggests that Mao's communist regime was quite effective in enforcing drug suppression and control. Cold War politics made drug suppression hostage to international security politics.

In the decades preceding the Second World War, a further series of international drug control conferences was held: in The Hague (1911-12), Geneva (1924-5) and Bangkok (1931). Narcotics control hit the international agenda with the rise in supply following the First World War when vast quantities of opiates were required to minister to the wounded. ${ }^{32}$ The League of Nations established its Opium Advisory Committee (OAC) to monitor the drug trade. Largely ineffective in view of Japan's and other great powers' (e.g. Britain's) lack of cooperation, the OAC proved to be a battleground for international rivalries, rather than effective narcotics control. Japan left the League of Nations in 1935, and the OAC in 1938, and its experiences here undoubtedly contributed to the policies it pursued in East Asia and the Pacific in the Second World War. Britain, too, resented US efforts to bring it to account over the drug trade (Jennings 1997: 64). In the 1920s, as Jennings has detailed, the 'recurring pattern of embarrassing revelations followed by pledges to take strong action against the drug traffic that ultimately came to nothing' (ibid.: 61) undermined the credibility of the OAC.

The 13 nations present in Shanghai in 1909 had promised to assist China eradicate opium; instead, the international community witnessed its expansion under Japanese domination. At the 1924-5 conferences, the eight nations attending the first conference on control of opium smoking called on the colonial powers in Asia to replace existing opium farms with government monopolies on the import and distribution of opium; the second conference attended by 30 nations resulted in a convention which established an international opium and narcotics supervisory body, the Permanent Control Board. It devised a system requiring governments to provide certificates for drug imports and exports. The US proposal for a 10 year 
deadline for the prohibition of opium smoking was rejected; Britain and other powers proposed instead that the League of Nations form a commission to determine when the opium producing nations were controlling output, such determination to be the trigger for a 15 year deadline on prohibition. This seemed like 'Sunday too far away'; the US delegation withdrew in protest from the second Geneva conference, followed by China. However, the conference had achieved a ban on heroin. The 1931 Bangkok conference achieved little; China refused to attend. In her absence, the Geneva convention was tightened; commission payments to opium retailers were abolished and smoking opium by persons under 21 years of age was prohibited. The advent of the Japanese initiated Manchukuo regime in 1932 heralded an opium monopoly regarded as 'the most significant threat to drug control in Asia' (Jennings 1997: 76). It took the victory by Mao's communist forces in 1949 to enforce the prohibition in China on non-medicinal use of narcotics.

As a province of British India, Burma was a signatory to the 1912 International Opium Convention. With the rise in nationalism after 1920, agitation to control the sale of opium in Burma proper increased. In response to the international environment, the Government of Burma sought to suppress poppy cultivation in the Kachin Hills where many Chinese from Yunnan had settled. However, the northern opium producing areas in the Shan States were free to continue to grow poppy. In 1922, the Federated Shan States (FSS) were created, which modified the system of indirect rule, replacing the authority of the traditional Shan rulers, the Sawbwa (or Saopha), with that of British advisers. In 1923 the Shan States Opium Order made non-medical opium illegal in most states except the most prolific producers, the Trans-Salween states, Kokang and Kengtung. As Renard observes, 'This meant that cultivation was allowed where poppies had been grown on a high level, but not allowed where there had been a lower level of cultivation' (Renard 1996: 30). Misleading reports presented to the League of Nations justifying this piece of chicanery contended that the production of opium in Kokang was small (ibid.). ${ }^{33}$ In 1937, the British-controlled Government of Burma banned opium production in the Kachin States, but not in the major poppy growing area of the Hukawng Valley. Poppy cultivation remained legal in the Wa States, the Naga Hills on the Indian border and in the Trans-Salween States. Despite many initiatives by the government of Premier $\mathrm{U}$ Nu to rid independent Burma of the drug menace, it was not until 1964 that concerted drug-suppression initiatives were launched. ${ }^{34}$ An Opium Enquiry Committee was formed to compile statistics on the number of addicts, revise existing laws and advise on substitute crops. From 1 October 1965, the cultivation and sale of opium in the Shan States was prohibited; and the Kokang Development Project was initiated to improve the socio-economic conditions in the primary poppy growing areas (Renard 1996: 50). Up until 1965, these areas had been

[F]ree to grow, sell and consume opium in the territories east of the Salween, where opium cultivation was more than two centuries old. The Burmese govt [under Ne Win] issued licences to shops in the western territories to produce opium. It allowed production for registered opium smokers, who were 
entitled to two viss (3.2kilograms) per smoker, per annum. Throughout the rest of Burma, the use of opium for non-medical purposes was prohibited.

(Renard 1996: 50)

For the first time since 1826, all of Burma was treated as an administrative unit with uniform drug-suppression laws applying throughout the sovereign state. Enforcement of these laws, however, has been hostage to the changing national security priorities during the decades of civil war and domestic politics since 1988. When international concerns led to the abandonment in 1973 of the Ka Kwe Ye (KKY) militia policy whereby local drug warlords such as Lo Hsinghan and Khun Sa were permitted to use government-controlled roads to transport their opium caravans in return for using their resources to combat the CPB, the government of Burma under Ne Win entered into agreements with the US in 1974 to suppress and control the narcotics trade. Both Lo Hsing-han and Khun Sa were later prosecuted and jailed, not for their involvement in the drug trade, but for having contact with insurgent groups such as the Shan State Army (SSA). ${ }^{35}$ Both were later released from custody under amnesty orders. Despite the cyber attacks of the Burmese Diaspora, the Myanmar government continues to enforce stringent narcotics control laws consistent with its 'strict moral code' (Renard 1996: 2); and imprisonment of offenders against these laws is frequently highlighted in the government controlled media. The official government perspective, as evinced by Senior General Than Shwe in 1992, is 'Opium endangers the entire human race' (Renard 1996: 2). In this the Myanmar government is at one with the early Burmese kings who prohibited its use and enforced severe penalties for those caught using it.

\section{Conclusion}

Drug-suppression operations, reduction of both demand and supply, are therefore central to effective poverty-alleviation strategies in Myanmar. Enforcement of narcotics control laws is vigorously pursued, and whilst corruption and the drug trade go hand in hand, efforts to combat both are evident. Development policies which expand the basic infrastructure in the poppy producing areas are as integral to narcotics control as are enforcement laws; socio-economic policies to improve the well-being of the peoples in the poppy-producing areas are important aspects of policies to reduce both the demand and the supply of the drugs. Beyond this, sustaining the prevailing conditions of peace in the formerly insurgent strongholds, is critical to being able to interdict the supply of drugs which finds its way onto the international networks operating out of the Golden Triangle. When human security in these areas is enhanced, so too will be both the national security of Myanmar and the broader security of the international community. From this perspective, resources and programmes which enhance the effectiveness of poverty-alleviation projects in the poppy-producing areas contribute to enhanced human security in the wider community - and the seven horsemen of the apocalypse which have brought so much suffering to the peoples of the poppy cultures - will have been overcome. 


\title{
4 Myanmar's external relations in regional context
}

\author{
Security enhancement
}

\section{Introduction}

As discussed in previous chapters, Myanmar's overarching search for national security is both political and economic reflecting its tortuous modern history, colonial experience and legacy of civil conflict since 1948, when the insurgencies of every major indigenous ethnic minority except the Chin erupted just as the newly independent state came into existence. Then, in 1988, as the state was emerging from 26 years of socialism and seeking to re-engage with the international market economy, international economic sanctions designed to undermine the regime and the state made that search for security problematic. In this sense, Myanmar reflects the prevailing liberal/constructivist view of security in the AsiaPacific which privileges economic development, political stability and social passivity more than the traditional militaristic Western approach of the realist paradigm, ${ }^{1}$ although South-East Asian governments, including Myanmar, are inclined to revert to the realist balance-of-power paradigm when taking measures to ensure that no regional hegemon can emerge. From time to time, this approach is apparent in their international policies towards China, Japan and the US.

Thus, in early 2004 it appeared that Myanmar's spate of diplomatic initiatives subsequent to the 25 August 2003 top structure changes, put in place to divert international criticism following the 30 May 2003 incident at Depiyin, northern Myanmar, were the latest in a series of strategies designed to deliver regime and state security to Yangon. As emphasized in previous chapters, the important correlative of human security is yet to achieve prominence in state discourse. The sudden removal from office of former Prime Minister, General Khin Nyunt on 18 October 2004 and subsequent wide-ranging purge of his followers, however, are clear indications of Myanmar reverting to indigenous paradigms of centralized authoritarian, personalized power, and resiling from the brief attempt to emerge into a modern pluralistic state. The situation in mid-2005 may yet prove to be a 'holding pattern' as Myanmar endures its worst period since 1974; human security is at its lowest ebb as demonstrated by the series of bomb explosions in Yangon in May 2005, and earlier in the market at Mandalay, and the recent food shortages which forced the SPDC to re-negotiate with the World Food Programme the terms on which assistance would be provided. Such an 
environment may yet impinge adversely on regime security. However, only substantive change in the top structure military leadership could usher in a more sustainable, modern approach to governance, and with the demise of the reform group, no alternative source of 'home-grown' domestic leadership appears obvious. The civilian opposition is in disarray, ageing, its leader under very restrictive house confinement; the former Prime Minister is similarly under house arrest; and the SPDC is in the process of retreating to the northern 'bunker' at Pyinmana. All suggest signs of a faltering regime desperate to reassert the trappings of control. For all its overweening concern with state and regime security, the SPDC may yet implode from within. If this occurs, it will be largely because of inept, inadequate and incompetent attention to the policies required to ensure the human security of Myanmar citizens. In mid-2005, no external nation is a credible threat to the state of Myanmar; threats to state security arise only from the policies pursued by its own leadership.

Since becoming a full member of the ASEAN in July 1997, Myanmar's domestic policies prior to October 2004 had been channelled towards convincing the international community that the concerted domestic reform programme underway in various sectors would accelerate opening the economy to full market status, and that this in turn would eventually lead to pluralistic governance. These objectives were reiterated in the 30 August 2003 plan announced by former Prime Minister, General Khin Nyunt. His colleagues amongst the Heads of Government at the Ninth ASEAN Summit held on Bali, 7-8 October 2003 were prepared to accept this plan, with its notable use of the term, 'disciplined democracy', intended to serve as a contrast to what the Myanmar leadership perceives as the 'undisciplined democracy' of the 12 years of the era of Parliamentary democracy (1948-58, 1960-2). The former Prime Minister's plan was perceived as the most positive approach to come out of Yangon for some time, and which could deliver the democratic governance said to be desirable by all parties - the government, the opposition, the minorities and the international community. The diplomatic initiatives accompanying both the plan and the government's responses to imposition of further sanctions by the US following the tragic 30 May incident at Depiyin in Upper Myanmar, suggested recognition in some senior echelons of the Myanmar leadership group that the country's overarching search for security must be pursued on both the political and the economic fronts. ${ }^{2}$ In response to political tensions after the Depiyin incident, the fragile economy faltered; citizens experienced further deprivation and the government's hold on power appeared shaky. Drastic measures were required to prevent a lurch into that instability which Myanmar's neighbours feared could be detrimental to the region as a whole.

It is an article of faith amongst South-East Asian demi-democracies ${ }^{3}$ that state security and economic prosperity go in tandem; state-led economic development has been a feature of South-East Asian governance since emerging from the colonial era. However, South-East Asian governments are also conscious that economic development alone does not keep authoritarian governments in power, a fact made plain by the demise of the Suharto regime in Indonesia, and previous authoritarian governments in Thailand and The Philippines. The 'dictator's 
dilemma' has always been how to achieve regime legitimacy and state security through economic development that fosters the growth of pluralistic alternate centres of power which may eventually challenge the authoritarian centre for control of the political life of the country. This is a dilemma also facing China; and has played out its assigned role in Taiwan, South Korea and Thailand in the decade of the 1990s where increasing prosperity arising from economic development eventually rolled back the tide of authoritarian governance.

In seeking state and regime security through economic development, the government of Myanmar implicitly acknowledged what James Rosenau (1997) has called the 'domestic-foreign divide'; that is, domestic security is a function of a country's international relations policy. In effect, domestic policy and international policy have become functions of each other. In Myanmar's case, this is demonstrated in the flurry of multilateral economic-political relationships which the country has overtly fostered, particularly since 30 August 2003. It is notable that this approach has continued even after the displacement of General Khin Nyunt in October 2004. Senior General Than Shwe's state visit to India was undertaken immediately after the purge was launched; his visit was seen as a measure of how secure the Senior General felt in his position that he could afford to be out of the country at such a time. The new leadership line-up also attended the ASEAN summit in Vientiane, Laos, in late 2004, and has continued to host a number of international visits from dignitaries from neighbouring countries. Concern for the regional implications of Myanmar's domestic developments led new Thai Foreign Minister, Kanthathi Suphamongkonon, to visit Yangon in August 2005, to discuss the political situation. Until the ASEAN summit in Vientiane in late July 2005, Myanmar's international, integrationist strategy had been in marked contrast to that of the neutralist stance independent Burma had followed, when the country was a founding member of the Non-aligned Movement (1955-79). The Senior General's withdrawal from the ASEAN chairmanship at that summit is being interpreted as one of a series of signs that Myanmar may be preparing to again retreat from the international community, or at least from some sections of it. More likely, the SPDC leadership is preparing to focus its resources only on those sectors of the international community which it considers will pay dividends in terms of its own regime security interests China, Vietnam, India and its primary trading partners, Thailand and Singapore. This menu of issues is behind the Thai Foreign Minister's talks in Yangon.

Part of the motivation underlying the SPDC security strategy until recently has been to seek immediate international support from neighbouring Asian countries, especially those which share sensitive, strategic borders with Myanmar. The other part has been to build a longer-term strategy for state security through economic development. But perhaps most importantly, in view of the implications of the changing international environment post-Iraq, and the US doctrine of pre-emptive strike, Myanmar had been building its strategic regional alliances through ASEAN and other regional groupings, with China, India, Japan and Thailand. These alliances may eventually form a regional bloc with sufficient collective power able to exercise considerable leverage against any future US moves 
intended to diminish the sovereignty of regional states, either individually or collectively. Such a set of economic-political alliances carries overtones of the realist balance-of-power approach to international relations. Given ASEAN's hard-won international credibility as a significant regional bloc, the internal disquiet amongst its members caused by the displacement of General Khin Nyunt, and the threat of boycott by major Western powers, if the current SPDC line-up were to have taken on the chairmanship of the Association, the original ASEAN members seemed relieved when Myanmar stepped back from assuming the chair in 2006; however, the sense of relief may be short-lived, if Myanmar again descends into that internal chaos which the pre-October 2004 regional strategies were trying to circumvent.

The overall regional strategies pursued towards Myanmar by key ASEAN states, and by Myanmar in regard to its fellow members in the Association, could be called a 'safety in numbers' game. The prosperous regional states like Thailand and Malaysia, perceive that their individual future security could be tied to that of their neighbours; instability in one regional state has flow-on effects for others. In 2003-4, Thailand's Prime Minister, Thaksin Shinawatra, explicitly recognized the interrelated aspects of economic security for all the region when he launched a series of initiatives to encourage Thai investment in Myanmar as part of his 'share the prosperity' policy. Myanmar's neighbours have vivid memories of the 1997 financial crisis, propelled by transnational financial interests based in the US, and the dire effects on the standard of living it had for their peoples. There is a deeply held view in the region, rightly or wrongly, that this crisis was artificially engendered in order to short-circuit the economic growth and increasing power, which the region had been experiencing up to that time. In Thailand, the rise of Thaksin Shinawatra's Thai Rak Thai political party is a reflection of this view of the ASEAN financial crisis, which severely challenged the ASEAN norms of 'national and regional resilience'. Subsequent diplomatic initiatives amongst the several regional organizations, and China, can be seen as designed to enhance their economic and political security, for what they perceive to be the coming contest between China and the US, a contest which may result in a return to bipolar centres of power, notwithstanding the goodwill visit to the US by Chinese Premier, Wen Jiaobao, during which President Bush publicly rebuked Taiwan for its proposed referendum on 'independence'. Southeast Asian states, aware of the dangers of US 'containment' policy towards the rising economic growth and power of China, will try to balance between China and the US, allowing neither one, nor the other to be able to dictate their futures, whilst benefiting both from China's economic growth and, where appropriate, as in the cases of Thailand, The Philippines and Singapore, the US military security umbrella. Until mid-2005, Myanmar's international relations policy has been part of this complex web of manoeuvres undertaken with the objective of consolidating regime and state security through close economic and political relationships with prosperous neighbouring states.

With the exception of the US, which, with the enactment of the Burma Freedom Act (2003) will now not accept any imports from Myanmar, the 
country's major trading partners are all within the Asian region. In financial year 2002, Myanmar's exports to Thailand were worth USD 831 million; to the United States USD 348 million; to India USD 194 million; to China USD 130 million; to Singapore USD 97 million; to Japan USD 97 million. Corresponding imports were: from China USD 636 million; from Singapore USD 576 million; from Thailand USD 355 million; from Korea USD 277 million; from Malaysia USD 217 million and from Japan USD 132 million (Asian Development Bank 2002). Given this trading pattern, and continuing sanctions by the US and the UK, it has been logical for Myanmar to focus its economic-political security strategy within the Asian region.

\section{Relations with the People's Republic of China (PRC)}

China has been Myanmar's most important international backer, enabling Myanmar to survive the 17 years of Western economic sanctions. From very precarious relations during the ascendancy of Chairman Mao Tse-tung when China was 'exporting revolution' and providing financial support to the CPB, the new era in cooperation and investment initiated under Deng Xiaoping culminated in the state visit by President Jiang Zemin in December 2001. Discussions during this visit precipitated a new round of Chinese investment in Myanmar, already substantial, particularly in Upper Myanmar around Mandalay where considerable Chinese migration and land purchases are evident. The November 2003 visit by a senior Myanmar delegation to China purportedly resulted in Chinese interest in further investing in the mining sector (Myanmar Times, 20 November 2003). The importance of the commercial relationship can be seen in the trade transacted: as noted earlier, according to Asian Development Bank figures, in financial year 2002, Myanmar exported USD 130 million to China and imported USD 636 million from China, a considerable trade surplus in China's favour. Strengthening the strategic commercial relationship underpinned the 14 December 2003 visit to Yangon by Chinese Assistant Minister of Commerce, Qian Jiang.

In January 2003, this special relationship saw China announce a further USD 200 million loan to Myanmar for improving electricity-generating capacity with obvious ramifications for development of Myanmar's industrial sector. This followed the earlier USD 250 million loan in 1998 when China funded a 280 megawatts hydroelectric power plant at Pyinmana, now to be the new centre of the Myanmar government. Implementation details of the new loan, pointedly, were announced at the same time as US President George W. Bush was signing into law the most recent round of economic sanctions preventing Myanmar from exporting to the US. These sanctions impacted adversely on Myanmar's textile exports and led to hardship for low-paid factory workers, mostly women, who were thrown into destitution when the factories employing them closed. The US sanctions also prohibited financial services (credit card facilities such as American Express, Mastercard, Visacard) from being provided to Myanmar in an attempt to further disrupt the country's trade. On 20 November 2003, the Myanmar Times announced that alternate markets for Myanmar's textiles were being developed. 
Since then further initiatives have been set in train to implement alternate credit facilities utilizing Euros to sustain the country's international trade and tourist industry. In this context of increasing, punitive US sanctions, China has been an important source of international political and financial support to Myanmar, ${ }^{4} \mathrm{a}$ relationship of mutual satisfaction given public prominence during former Prime Minister, General Khin Nyunt's July 2004 visit to China when 12 new agreements between the two countries were signed (Taipei Times, 24 July 2004).

Does China regard Myanmar as being part of her 'sphere of influence'? Undoubtedly so, along with other South-East Asian countries. Since 1990 China has been the largest supplier of arms and military equipment to the Myanmar military, although not the only source; others are Israel and Singapore (Selth 1996). A USD 1 billion arms deal with China in 1991 provided Myanmar with 11 Chinese F7 jet fighters, naval patrol boats, armoured personnel carriers, antiaircraft guns and missiles, tanks and ammunition and initiated a series of state visits to each other's countries by the leaders of both Myanmar and China. The framework for bilateral relations and future cooperation agreed in 2000 paved the way later that year for the opening of the new special trade zone along the Myanmar-China border facing Yunnan, now experiencing economic 'boom' conditions. China has funded both the development of the new deep-sea port at Tilowa facing the Bay of Bengal and the new six-lane highway connecting the port with Yangon and Mandalay, which runs up the Ayeyarwaddy Valley to Yunnan. Such a highway provides essential infrastructure for Myanmar's developing industrial sector and for the marketing of its agricultural products.

But such a highway is not just for commercial uses. In times of conflict, if necessary, this highway would provide the transportation route for rapid transfer of troops across the length of Myanmar. The Myanmar government is conscious both of China's desire to be able to re-victual her Indian Ocean nuclear submarine fleet from Tilowa and the possible strategic uses of this highway in any future conflict in the region. Firmly committed to maintaining its autonomy and independence from all comers, Myanmar at the present time does not allow any foreign power to establish bases on its territory, or to allow its territory to be used for incursions by guerrilla forces against neighbouring sovereign states. In 1998, it took the then Indian Defense Minister, George Fernandes, to task for suggesting that Yangon was permitting China to set up bases within its territory. However, in 2000, Myanmar accepted the assistance of Chinese engineers in the construction of two naval bases in the southern Tenasserim region. Myanmar thus takes the stance of a sovereign power enjoying the political, economic and international support of China whose backing has been critical in minimizing the impact of Western sanctions imposed since 1988.

Although China has been a good friend and financial backer for Myanmar in time of need, this friendship has not been viewed without considerable misgiving in certain quarters of the Myanmar government, conscious of the past history of conflictual relations with China, despite being the first country to accord official recognition to the PRC in 1949. At the present time, as demonstrated by the discussions between former Prime Minister, General Khin Nyunt and Chinese 
Premier Wen Jiaobao after the 7-8 October 2003 Ninth ASEAN Summit in Bali, Myanmar and China are enjoying a period of warm friendship. This has continued despite the removal from power of General Khin Nyunt, about which China pointedly refrained from making any public comment. Mutual interests in strengthening their trade and investment, enhancing economic growth and outmanoeuvring incipient US containment policy towards China, draw the two countries together. Conscious that it needs to keep its own economic growth on the boil, if it is to continue both its domestic reform agenda and position itself in future to take its place as a pre-eminent power on the world stage, China is seeking every opportunity to develop its trade and investment in the region, and to show that it is a responsible international player. ${ }^{5}$ It is thus in China's own interests to foster poverty-alleviation strategies in Myanmar, policies to strengthen Myanmar's economic growth and stability and cooperation on issues affecting the social fabric of both countries such as drug-suppression operations, prevention and treatment of HIV/AIDS and human trafficking, all of which impinge on both human and state security.

As a nuclear power, China's support carries a good deal of bargaining weight. In the wake of the ASEAN Bali summit, it is likely this relationship will grow as the 10 members of ASEAN seek to enhance their economic security by hooking onto China's rapidly growing economy. Indicative of the strengthening of this two-way relationship, is the visit to Myanmar on 18 November 2003, by an eightmember Chinese delegation led by Mr Ye Xueming, President of the Chinese Chamber of International Commerce. Discussions on increasing trade and investment were held at the Yangon headquarters of the Union of Myanmar Federation of Chambers of Commerce and Industry (UMFCCI). Particular attention was paid to exports to China of Myanmar timber and wood furniture, with corresponding imports of Chinese farm machinery and personal goods to Myanmar, leading to signing of a formal trade agreement (Myanmar Information Sheet, 19 November 2003). Further commercial delegations from China to Myanmar, and a series of visits by dignitaries to each other's countries continued throughout the first half of 2004 and early 2005. A 25-member Chinese business delegation led by Mr Wan Jifei, Chairman of the China Council for the Promotion of International Trade, attended the Third Annual Meeting of the ASEAN-China Business Council in Yangon in June 2004 (Myanmar Times, 14-20 June 2004). This meeting was held subsequent to agreement on the establishment of a China-ASEAN free-trade zone by 2010, which would cover 1.7 billion consumers across the 11 countries with a combined gross domestic product of 2 trillion dollars, whose two-way trade already exceeded USD 100 billion in 2004 (Kuik 2005: 118). As the famous 'back-door' to China (see Chapter 3), Myanmar is obviously a key link in China's own security framework which is being pursued through both multilateral and bilateral means. Kuik (2005: 118) is surely correct in the emphasis he places on China's policy imperatives to foster a multi-polar world - NAFTA, EU and East Asian groups - wherein Asian regional economic integration strengthens the common identity and 'collectivity' of the individual Asian countries, serving to differentiate them increasingly from the US in future. 
It is therefore in China's own interests to seek to foster political stability in Myanmar; above all, China would be most unlikely to want to see the installation of a US proxy-democratic regime which could provide a bastion for revival of future US encirclement of China, as in the era of 'containing communism'. Memories of US support for the Kuomintang incursions in northern Myanmar in the 1950 s- 60 s remain strong in both Yangon and Beijing. Yangon has strictly adhered to the 'One-China' policy, much to Beijing's considerable satisfaction. The Myanmar government can therefore feel reasonably sure of continued Chinese support, politically and economically. To head-off any Chinese pretensions to treating Myanmar as a satellite state, however, all indications are that Myanmar will seek to balance Chinese influence with that of India.

Noting the special strategic significance of Myanmar to its more populous and wealthier neighbours, Uday Bhaskar, considers that Myanmar

$[\mathrm{H}]$ as the potential to emerge as the most significant swing state in the strategic mutuality of India and China, and the bilateral relationship between them will be affected considerably by the manner in which the two Asian giants relate to their smaller neighbour.

(Bhaskar 2000: 349)

Myanmar's geopolitical position, Bhaskar emphasizes, is 'of abiding relevance' (ibid.). As both China and India seek to establish themselves as major powers in the twenty-first century, China's access to the Indian Ocean/Bay of Bengal littoral may become a key strategic security consideration. As Bhaskar (2000: 355) notes, all major powers have been 'two-ocean capable'; Myanmar's continuing goodwill and cooperation are therefore of special relevance to Chinese security planners, if the 'twenty-first century Silk Route', the oil arc from the Persian Gulf across the Indian Ocean and through the Straits of Malacca to the South China Sea is to be protected. Protecting and enhancing energy security are prime considerations for both China and India as these two emerging major powers seek to sustain their phenomenal economic growth.

\section{A friend in need - India and security enhancement}

Around the Bay of Bengal, India, the other nuclear power sharing a border with Myanmar, has also recently moved to offer substantial international, political and economic support for Myanmar in what is quite clearly a concerted policy by India to counter Chinese commercial and military influence in Myanmar. The state visit to Myanmar on 2 November 2003 by former Indian Vice-President, Mr Bhairon Singh Shekhawat, signalled a distinct warming in Myanmar-Indian relations and a marked departure from that prevailing after the 1988 democracy uprising in Yangon, when India gave sanctuary to those fleeing the civil unrest. At the time, the former Indian Vice-President was the highest ranking Indian leader to visit Myanmar since the visit of the late Prime Minister, Rajiv Gandhi in 1987. In 2002, India resumed arms shipments to Myanmar to balance what it saw as the 
growing influence of China (Agence France Presse, 3 November 2003). India's economic growth of 6-7 per cent annually for the past 14 years, and large, affluent middle class provide an attractive export market to Myanmar, cut off as it is from other potential markets by Western economic sanctions. India's engagement policy with Myanmar as part of its 'Look East' policy generally, offers the Myanmar government a welcome counterweight to that of China.

The visit of the former Indian Vice-President was billed as a goodwill visit. On 3 November 2003 he paid a courtesy visit to the Chairman of the SPDC, Senior General Than Shwe, at the diplomatic hall of the Pyithu Hluttaw (Parliament House) and was hosted for dinner by Vice-Chairman of the SPDC, Vice-Senior General Maung Aye. Indicative of the importance accorded the visit on the Indian side, the former Vice-President was accompanied by a substantial delegation including former Minister of State for External Affairs, Mr Digvijay Singh, Member of Parliament (RS) Mr Anil Kumar, Member of Parliament (RS) Mr B. J. Panda, Foreign Secretary Mr K. Sibal, Secretary to Vice-President Mr Anil Kumar, and departmental officials.

However, it was more than a goodwill visit. It included the signing of an India-Myanmar Bilateral Agreement on visa exemption for official and diplomatic passports, and a Memorandum of Understanding between the Myanmar Ministry of Education and the Indian Ministry of Human Resource Development to increase the number of scholarships provided by India, in order to enable Myanmar students and teachers to gain the qualifications needed to assist the country in its development. These agreements build on a series of others signed in recent years dealing with border trade, drug control, cultural exchanges, cooperation on agriculture and information technology development. India is also providing assistance to Myanmar on biotechnology investment, and the two countries have established a Joint Trade Committee.

During this visit, the former Indian Vice-President made available to Myanmar a USD 57 million line of credit for assistance in upgrading the Yangon-Mandalay railroad, which will enhance the country's efforts in economic development, as well as planning further development of the India-Myanmar-Thailand highway. The new cooperation policy has been continued by the incoming Indian government which sent a series of high-level delegations to Yangon in 2004 to strengthen the bilateral relationship; and followed up in March 2005 with the state visit by the new Indian Prime Minister, Manmohan Singh, together with the current Indian Minister for External Affairs, Mr K. Natwar Singh. Discussions were held with the top SPDC leadership on both border security issues and India's requirements in pursuit of energy security, on which, the Indian Prime Minister frankly confessed, China was well ahead of India. (Asia Times, 17 March 2005). The world's sixth energy consumer, India imports two thirds of its oil consumption requirements, as compared to China's one third; and India is reported to have only 5 billion barrels of oil reserves compared to China's proven oil reserves of 18 billion barrels. India's energy needs thus figure largely in its new bilateral relationship with Myanmar in whose offshore gas reserves it has considerable interest. 


\section{External relations in regional context}

These initiatives built on those announced previously in 2003 to increase cooperation between India and Myanmar in the development of the hydroelectric power and energy sectors, including the exploration of Myanmar's oil and gas reserves. Indian External Affairs ministry spokesman, Navtej Sarna, had previously announced on 22 January 2003 that two Indian teams would visit Myanmar to explore the prospects of exploiting onshore hydrocarbon reserves, and examine the construction of a 1,000 megawatt hydroelectric dam on the Chindwin River at Tamathi in Sagaing Division. It is planned that some of this electricity will be sold to India (Myanmar Times, 17 October 2004). Discussions in Delhi in July 2003 between U Win Aung, the first Myanmar Minister for Foreign Affairs to visit India since 1987, and former Indian External Affairs Minister, Yashwant Sinha, had foreshadowed this closer cooperation in the development of the hydroelectric and energy sectors, as well as joint construction of roads, and collaboration in regional organizations. These initiatives were reiterated during an October 2004 visit to Yangon by Indian Foreign Secretary, Shyam Saran, who highlighted India-Myanmar plans to increase cross-border trade through the new checkpoint at Reedkhawdhar in Chin State, and the construction of roads linking India's Mizoram state with Tiddim and Falam in Chin State. However, in late March 2005, Yangon suddenly announced a ban on foreign firms being involved in onshore oil and gas exploration and production, stating that this activity is in future to be reserved for state enterprises, although contracts with foreign firms including those from China and India (as well as Canada, France, Korea, Malaysia, Thailand and the US) engaged in offshore oil and gas exploration seem to be unaffected. ${ }^{6}$ Export of natural gas is one of Myanmar's largest earners of foreign currency.

These series of strategic discussions with India to enhance bilateral economic cooperation included strengthening their interactions in BIMST-EC as well as a series of political issues arising from the current international situation in Iraq, according to an Indian External Affairs Ministry spokesman. With respect to antiIndia insurgent groups operating in Myanmar, former Foreign Minister, U Win Aung had specifically stated that Yangon would not allow its territory to be used by any group that would harm New Delhi's interests, a reference to cross-border terrorist activities in north-west Myanmar. Both initiatives now appear to be tied up with the changing international security scene; the overland $900 \mathrm{kms}$ gas pipeline from Myanmar's offshore Shwe field to India proposed to cross Bangladesh, which stands to gain USD 125 million in transit fees, access to the gas and creation of a trade and transport corridor linking it with Nepal, as well as access to India's power grid. However, tensions over rising Islamic fundamentalism and anti-India sentiment in Bangladesh under the Bangladesh National Party (BNP) have slowed progress on the project. It is noteworthy that during the visit of Indian Prime Minister Manmohan Singh, Senior General Than Shwe reaffirmed Myanmar's commitment to cooperation with India in maintaining the security of their shared border, and not allowing insurgent groups to use Myanmar territory to launch attacks against India in the north-west. ${ }^{7}$ It is possible that complications arising from the India-Bangladesh cooling in relations 
may have had some effect in leading to Yangon's decision to discontinue onshore oil exploration by foreign firms, or it may simply be a return to the nationalistic, autarchic policies of former times. If the land pipeline proves impracticable, India will need to consider an alternate, more expensive route under the Bay of Bengal to by-pass Bangladesh, or a route through north-west Myanmar.

Despite these difficulties, the warming in relations between Myanmar and India is proving productive for both countries. Economic ties between Myanmar and India are becoming increasingly important. Bilateral trade grew from USD 87.4 million in 1990-1 to USD 323.43 million in 2001-2; India's exports to Myanmar were worth USD 37.57 million and imports worth USD 285.86 million, making a substantial trade balance in Myanmar's favour. In the fiscal year to March 2004, India-Myanmar bilateral trade was valued at more than USD 400 million. Myanmar exports mainly beans and pulses, timber and gems to India, from which it buys pharmaceuticals, building materials, steel and wheat. Both sides have said they hope to boost trade to USD 1 billion by 2006 . If recent initiatives are sustained, this trade is likely to grow to the advantage of both countries. $^{8}$

The success of India's Look East policy after a couple of 'start-stops' in the mid-1990s and the consternation caused by its nuclear test in 1998, is directly linked to both the changing international relations framework post-11 September, 2001, and the US invasions of Afghanistan and Iraq. India is keen to strengthen its ties with South-East Asian countries whose leaders also are exerting diplomatic efforts to develop stronger intra-Asian economic and political partnerships as bulwarks against the new unilateralism, the US doctrine of pre-emptive strike and continuing Western pressures on human rights, democracy and trade. The success of India's Look East policy is also linked to India having changed its previous inward-looking economic policies, recovered from its reliance on the former Soviet bloc, improved its relations with the US and revitalized its economy. India in effect has 'come in from the cold'.

The success of its Asian diplomacy is seen in the initiatives being taken for joint development of information technology, military exchanges and confidencebuilding measures which have resulted in India's membership of regional organizations such as the ARF. Following the Bali summit, the ASEAN nations both collectively and individually signed an ASEAN-India Regional Trade and Investment Agreement (RTIA) which came into effect on 1 July 2004 for the enhancement of economic cooperation. The provisions of this agreement specifically are designed to enable the newer ASEAN members - Myanmar, Laos, Cambodia and Vietnam - to accelerate their economic development through participation in a range of trade-liberalization measures.

Now a dialogue-partner of ASEAN, India held discussions with former Myanmar Prime Minister, General Khin Nyunt and other regional leaders, after the Bali Summit, ${ }^{9}$ and in October 2005 hosted the state visit by Senior General Than Shwe. From Myanmar's point of view, it now has the friendship, economic and political cooperation of the region's two nuclear powers, with both of whom the country shares sensitive, strategic borders. ${ }^{10}$ No longer in retreat from the 


\section{External relations in regional context}

world, India is embracing globalization as a means to realize its potential to become a major power in the twenty-first century. In recognition of the key strategic role India is likely to play in the coming decades in sustaining regional peace, security and economic growth, China's Premier Wen Jiabao visited India in April 2005 to discuss a possible free-trade agreement and to iron-out some of their contentious border issues. As a result, in a remarkable about-face, China recognized Sikkim as being within the Indian sphere of influence; in 2003, India had recognized Tibet as part of China. However, India's claims to part of northern Kashmir, ceded to China by Pakistan, have yet to be resolved. In view of China's longstanding alliance with Pakistan, India is wary of any potential encirclement of itself which could result from China's relations with Myanmar. However, since 1997, and in view of its concerted policy to improve economic and political relations with India, China has moved to distance itself from Pakistan's nuclear programmes. Clearly conflictual relations with India are now out of fashion in Chinese international relations policy. Both these nuclear powers, India and China, have come to realize that practical and strategic considerations move them in the direction of further economic cooperation and collaboration, putting the bitter memories of past conflict behind them. Their bilateral trade in 2004 grew by a massive 79 per cent to USD 13.6 billion. From India, China imports iron ore, steel, fodder, cotton, auto parts and jewellery; from China, India imports chemicals, silk and consumer electronics. China is India's second most important trading partner after the US (The Australian, 5 April 2005). On good terms with both, Myanmar stands to benefit substantially from further economic and strategic cooperation with these two emerging major powers, and may form part of a new growth quadrangle which includes South-West China/Yunnan, North-East India, Myanmar and Bangladesh. ${ }^{11}$ One cannot but agree with Bhaskar (2000: 359) therefore in suggesting that Myanmar 'has the potential to impact significantly... in the security calculus of India and China'. And both are clearly integral to Myanmar's own strategies for its security enhancement.

\section{Ties with ASEAN - fortifying regional resilience}

\section{Thailand}

It is no secret that historically Thailand and Myanmar (and their former incarnations as Siam and Burma) have not enjoyed friendly relations. Before the irruption in mainland South-East Asia of the British and French colonial powers in the nineteenth century, this region was torn asunder by the Siam-Burma wars of the sixteenth-eighteenth centuries, as each country sought hegemony through control of the international trade routes crossing the Malay Peninsula and around the Bay of Bengal, and related revenues (James 2000: 75-108). That struggle culminated in the Burmese sacking of the Siamese capital of Ayutthaya in 1767 and precipitated 40 years of warfare between the two countries up to 1809. Although the Siamese had the upper hand in this contest, driving the Burmese out of the country and establishing the new capital at Bangkok in 1782, it was only the British 
victory in the first Anglo-Burmese War (1824-6) which really broke Burmese military power in that era in mainland South-East Asia. This is a conflict forever relived in contemporary Thai film, novels and drama, becoming the making of legend and contributing not a little to the modern Thai perception, in the popular imagination, of the evil Burmese (Chutintaranond and U-Sha 2001). History has been embellished in the process.

In recent years, relations between the two neighbours have, from time to time, been strained over the flow of metamphetamines and other drugs flowing into Thailand from the Myanmar border regions; the activities of refugees; Thai fishing trawlers intruding into Myanmar waters; insurgent groups such as the KNU which blew up a bridge on the Thai side at Mae Sot and border clashes (Maung Aung Myoe 2002). From time to time, the government-controlled Myanmar press has disparagingly referred to Thailand as Yodya (i.e. Ayutthaya) recalling the past history of the two countries. In 2001-2, the takeover of a hospital at Ratburi near the Thai-Myanmar border by Burmese insurgents who were later killed by Thai forces and the attack on the Myanmar embassy in Bangkok by student activists further added to strained relations.

Nevertheless, Thailand has maintained a policy of 'constructive engagement' with Myanmar throughout both the previous Democrat administration of Chuan Leekpai (despite some attempts to change this to 'flexible engagement' during the term of office of former Thai Foreign Minister, Surin Pitsuwan) and the current conservative coalition of Prime Minister Thaksin Shinawatra. In early 2002 strategic initiatives by senior echelons of Thai society resulted in an exchange of state visits between the two countries: Senior General Than Shwe and his wife were received in audience at Chitrlada Palace by His Majesty, King Bhumibol Adulyadej and Queen Sirikit; and the Thai Crown Princess, Maha Chakri Sirindhorn, visited Myanmar. Other visits to Myanmar by key members of the Thai government including the Prime Minister and the former Foreign Minister, and then Deputy Prime Minister, Surakiat Sathirathai, followed. In turn, the former Prime Minister, General Khin Nyunt visited Thailand in mid-2004 and was also received in audience by His Majesty, King Bhumibol Adulyadej. It is no secret that in general, relations between the two countries tend to be more amicable during the tenure of conservative governments in Thailand than when the Democrats are in office.

Following the 30 May 2003 debacle in Myanmar, Thai Prime Minister, Thaksin Shinawatra, initiated what might be called a 'good neighbour' policy. As the Myanmar government was reeling from the international reaction to the Depiyin incident, Thailand announced its roadmap for Myanmar to return to democratic governance; shortly afterwards, former Prime Minister, General Khin Nyunt announced his own roadmap. To observers, it was a little mysterious that no-one, including the Myanmar government, appeared to have any details of the Thai version. There was a view that the Thai roadmap was a psychological prompt to Myanmar to take this initiative. Since the 30 August 2003 announcement of Myanmar's seven-point plan to move to democratic governance, Thailand has consistently supported Myanmar, both in the ASEAN forum and internationally, 


\section{External relations in regional context}

and on 15 December 2003 hosted a ten-nation conference in Bangkok on Myanmar's seven-point democracy plan. ${ }^{12}$ In 2004, Thailand supported Myanmar's admission to the EU-ASEM group; and Myanmar Foreign Minister, U Nyan Win, attended the 8 October 2004 Hanoi summit. Established in 1996 by 7 ASEAN members and 15 EU members, the EU-ASEM group now includes all 10 of the ASEAN countries and 25 of the EU countries. Speaking in Hanoi, former Thai Foreign Minister, Surakiat Sathirathai, said the forum provided a useful venue for Myanmar to be able to explain its progress with democratization initiatives to the European countries (Myanmar Times, 8 October 2004). It may be that the Thai leadership is conscious of the long road Thailand herself has trod, not without some backward steps, from the military dictatorship of 1948-73; the brief flirtation with democracy in 1974-5; the return of military rule in 1977-85; and again in 1991-2, before finally finding its democratic feet. Indeed there are some academics and civil society groups even now who fear that civil liberties in Thailand are again being eroded in a return to authoritarian, personal-style governance reminiscent of former eras under strongmen, Phibulsongkram (1948-57) and Sarit Thannarat (1957-63). ${ }^{13}$ In mid 2006, public protests by these civil society groups led to a constitutional crisis in Thailand.

Thailand's firm stance in refusing to go down the US sanctions approach, and in maintaining its engagement policy towards Myanmar, parallels that of India. This approach resulted in the 12 November 2003 four-nation economic summit at Bagan, sponsored by Thai Prime Minister, Thaksin Shinawatra, and including Laos and Cambodia as well as Myanmar, in what Thaksin calls a 'prosperity sharing' policy. The summit appears to have been very successful with an announced agreement on principles for economic development resulting from it, and subsequent visits by senior officials to hold discussions on aspects of implementation.

The natural question has been asked, given the history of relations between the two states, are the Thai sincere? In this case, the answer is probably in the affirmative. It is in Thailand's interest that her neighbours enjoy an increasing level of economic prosperity, as this assists in fostering political and social development, and contributes to stability in the region. Thailand does not want huge refugee outflows which result from instability in neighbouring countries. It is still sending Cambodian refugees home, years after the settlement (Bangkok Post, 21 September 2003).

In the lead up to the economic summit, the former Thai Minister of Commerce, Adisai Bodharamik, announced support for the purchase of Myanmar manufactured goods and raw materials. Seeking to increase trade between the two countries, he noted that in 2002, Thailand exported goods to Myanmar, both through direct trade and border trade, worth around USD 300 million, with a 30 per cent increase in trade in the first nine months of 2003, the largest increase up to that date. ${ }^{14}$ Noting that Myanmar enjoyed a considerable trade surplus with its major trading partners, Thailand, the US, ${ }^{15}$ India and Japan, the former Minister for Commerce stated that trade facilitation was being supported by the new regulations set by the Myanmar government. A team from Kasetsart and Mahidol Universities in Bangkok arrived shortly after the Bagan summit to advise on propagation of orchids and other plant species, and in a further sign of the 
developing close relations between the two countries, a 77-member Thai delegation led by President of the Thai-Myanmar Cultural and Economic Cooperation Association, General Pat Akkanibut and General Secretary, Sanan Kajornklam visited Myanmar on 23 November 2003 to attend the third meeting of the Thai-Myanmar and Myanmar-Thai cultural and economic cooperation associations. It is clear, therefore, that both sides see it to their mutual benefit to increase trade and commerce, cooperate on economic development and cultural matters, and support the peaceful political evolution of Myanmar, as a 'win-win' situation for the region.

Myanmar's key role in enhancing the security of the region has been highlighted in the regional efforts towards eradicating terrorism, post-11 September, 2001, and the Bali bombings of 12 October 2002. Myanmar and Thailand initially cooperated, with some success, in joint operations on the shared border along their Andaman Sea coast, as Thailand and Malaysia have also done with respect to the southern Thai provinces; and as Myanmar has also cooperated with India, Bangladesh and China along their respective western and northern borders. The 'war on terrorism' has underlined the necessity for regional cooperation on this issue. Since both Myanmar and Thailand have provinces with substantial Muslim populations - Rakhine state along Myanmar's exposed western coast, and the four southern Thai provinces which have had an Islamic separatist movement for decades - both countries are acutely aware of the necessity to manage the terrorist threat cooperatively. ${ }^{16}$ Both also cooperate in this matter with the major world intelligence agencies. Indicative of the developing strategic relationship was the 26 November 2003 visit by then Thai Defence Minister, General Thammarak Isarangura and delegation who was received by Head of State, Senior General Than Shwe, and hosted for dinner in the evening by SPDC member, General Thura Shwe Mann. Such visits not only provided opportunities for exchange of information, but also, importantly contributed to the confidence-building exercises which appeared to be going on between the two countries. ${ }^{17}$

Even the spate of urban bombings in Mandalay in late 2004, when two people were killed in the main market, and in three busy shopping centres in Yangon in early May 2005 which killed at least 16 people, did not unduly disturb the generally amicable relationship which has resulted from Thaksin's diplomatic initiatives. In response to Yangon's initial announcements that the bombings were the work of terrorists based in a 'neighbouring state' with support from international exile communities, Bangkok calmly declared that it does not, and did not support any such groups carrying out terrorist missions in Myanmar. Alternate possibilities were then canvassed in Yangon with eyes being turned towards some of the remaining insurgent groups in the northern border areas of Shan State, although these also denied involvement. However, to date, no clear perpetrators have been found. It is noteworthy that the tragic incidents did not result in deterioration in the Thai-Myanmar relationship and descent into acrimony as had happened at other times in the past.

Thailand also declined to accede to calls from some sections of the ASEAN community for Myanmar to forego the ASEAN chairmanship in 2006. Despite 


\section{External relations in regional context}

virulent accusations by some human rights groups based in the UK, and by Alternate ASEAN (ALTSEAN) spokespersons, for Myanmar to be deprived of this honour, Thailand stood firm both on Myanmar's membership of ASEAN and on its chairing the association in 2006. Thus Thailand, under the stewardship of Prime Minister Thaksin Shinawatra, holds to its policy that economic development in the long run is a more effective vehicle to bring about sustainable peaceful evolution of Myanmar's governance than punitive - and ultimately vindictive measures by a small number of external forces. The issue has tested ASEAN's long-established norms. In the wake of Myanmar's decision not to take up the ASEAN chair in 2006, in favour of concentrating on its domestic problems, Thailand sought immediate consultations with Yangon. Like China and India, Thailand has taken a long-term, strategic view of regional security and the contribution a stable, and prosperous Myanmar will make to its sustainability.

\section{Other ASEANs - perspectives on Myanmar}

Amongst other ASEANs, Malaysia and Singapore have played key roles, both in terms of political support, economic trade and investment as well as in support for human resource development, including training opportunities in the health sector. Both are key trading partners of Myanmar, with considerable commercial interests in the tourism and industrial sectors. The Government of Singapore Investment Corporation, for example, with USD 1.3 billion worth of investments in Myanmar, is one of the biggest commercial stakeholders in the country, exporting USD 576 million to Myanmar in financial year 2002 (ADB 2002). In addition, Singapore has provided arms and military equipment and training to Myanmar (Selth 1996) and takes a keen interest in its ongoing strategic developments. As Singapore's Elder Statesman, Lee Kuan Yew observed (Straits Times, 11 August 2005), Myanmar 'cannot stay frozen in time forever'.

Malaysia has also taken steps to increase its investments in Myanmar. In August 2002, former Prime Minister Dr Mahathir, accompanied by a considerable business delegation, paid an official visit to Myanmar, which resulted in further two-way trade and investment agreements. Both countries have provided substantial educational opportunities for Myanmar students, academics and officials to gain qualifications from their tertiary and technical institutions. Malaysia has taken a critical role, through UN special envoy, Tun Razali Ismail, in seeking to broker a reconciliation pact between the Myanmar government and Daw Aung San Suu Kyi. Whilst little of a substantial nature has been achieved through this process yet, it is certain that it at least highlighted the need for confidence-building interactions on both sides. Following Daw Aung San Suu Kyi's renewed incarceration after the 30 May 2003 incident, Tun Razali Ismail was one of the first foreign interlocuteurs to be given permission to visit the NLD leader. He was thus able to assure the world that she was safe and unhurt. He has, however, not received permission to enter the country again since this visit.

Other ASEAN countries, Indonesia and Brunei have played a similar political-economic supportive role, although, since the passing of power from ex-President Suharto, the political relationship between Myanmar and Indonesia 
is not as close as it was during the Ne Win era. ${ }^{18}$ The new democratic era in Indonesia has seen its newly empowered civil society call for similar strengthening of the institutions of civil society in Myanmar, which, at present, as one might expect in a military-controlled state, are only nascent. The Sultan of Brunei and his entourage paid a state visit to Myanmar in 1998 for the purpose of fostering trade and investment. Being similarly economies-in-transition, and new members of ASEAN, the former Indo-China countries have much in common with Myanmar. Vietnam and Myanmar maintain a particularly close relationship. As with China, Myanmar watches closely the progress of economic liberalization initiatives, land reform and property rights policies in Vietnam. Indeed, it is not impossible that the eventual outcome of the seven-point plan to return Myanmar to democracy could take the one-party form of that found in Vietnam with a continuing dominant role for the military assured in the new Constitution, whilst administrative activities are carried out by an elected body (Clark 1999). ${ }^{19}$ The Philippines, the ASEAN state closest in political and historical ties to the US, probably has the coolest relations with Myanmar and comparatively little investment.

\section{Relations with other regional organizations - BIMST-EC, GMS, ARF}

Myanmar has been promoting its international relations also through its membership in various regional organizations, BIMST-EC (founded 1997), the Greater Mekong Subregion (GMS) and the ARF. ${ }^{20}$ In addition to the four-nation Bagan economic summit on 12 November 2003, Myanmar hosted, on 18-20 November 2003, an Experts' Meeting to work out an agreement for implementing a BIMST-EC free-trade area during which trade and services for facilitating investment in the region were discussed. ${ }^{21}$ A subsequent BIMST-EC summit planned for Phuket, Thailand in early 2004 was postponed at the request of the former Indian Prime Minister who cited pressing domestic concerns (Myanmar Times, 26 January 2004). It had been intended to consider at the summit applications from Nepal and Bhutan to join the group; these two countries formally joined in February 2004. At the summit, finally convened on 30 July 2004 in Bangkok, plans were launched to establish a free-trade zone amongst the members by 2017.

Similarly Myanmar participates in the 10 year development plan for the GMS which is funded mostly by the Asian Development Bank (ADB) and focuses mainly on a number of large-scale infrastructure projects, particularly dams for the generation of hydroelectricity. Some tourism and health promotion initiatives, particularly prevention and control of HIV/AIDS, and initiatives to counter human trafficking in the border regions are also sponsored through the GMS. Myanmar's participation in the ARF by virtue of its being a full member of ASEAN (since 1997) provides the opportunity for participation in discussions on regional security, arms limitations talks and counter-terrorism measures. Such participation is seen as an important aspect of socialization, and confidence-building measures amongst the ASEAN leaders with a keen interest in the nascent security community potential of the ARF. As signalled by Lee Kuan Yew (noted earlier), 
there is a clear awareness in certain quarters of ASEAN that isolating Myanmar is not in the long-term strategic interests of the region, and only plays into the hands of the current SPDC leadership, some of whom would welcome the opportunity to become disengaged from the international community.

\section{Bangladesh}

Myanmar's border with Bangladesh has always been a sensitive region. Given the predominantly Muslim population of Rakhine province abutting Bangladesh, the Myanmar government is always alert to the possibilities of communal unrest and terrorist elements taking refuge there. It was cross-border disturbances in this region which became the cassus belli precipitating the first Anglo-Burmese War in 1824. Thus a news report of 2 November 2003 that the border trade with Bangladesh appeared to be operating as normal through the Maungdaw-Teknaf transit point opposite Cox's Bazaar indicates close official scrutiny of what was occurring here at the same time as the Upper Myanmar communal disturbances at Kyaukse, between local Muslims and Buddhists. That the local border was not sealed shows that the Myanmar authorities felt confident of keeping control of any outbreaks of unrest. However, Bangladesh's security forces were on alert for any influx of refugees from Myanmar's Rakhine state, where groups of people from Sittwe (Akyab) and Rathidaung were reported to be camped close to the Bangladesh border fearful that the communal riots in Kyaukse could lead to further repression of their own communities. ${ }^{22}$ The question of cross-border refugee flows, with its attendant security risks, is at the forefront of Myanmar's strategic discussions with its neighbours, all of whom have a stake in the country's stability, economic development and capacity to provide a better living for its citizens. As discussed earlier, the rise in Islamic fundamentalism in neighbouring Bangladesh accompanied by anti-Indian sentiment has recently caused complications in India-Myanmar economic cooperation on energy security, a complication which needs to be resolved with Bangladesh's full participation if all three are to benefit. In an effort to put some distance between itself and the India-Bangladesh tensions, in July 2004 Myanmar separately entered into a series of discussions with Bangladesh on trade protocols and joint minerals exploration. All of Myanmar's neighbours are thus closely interlinked, through economic and security interactions, with the country's gradual progress towards a prosperous, modern polity. Since the consequences of poverty are a potential threat to all, poverty-alleviation measures in the form of concrete trade and investment initiatives are at the forefront of their strategic initiatives.

\section{North-East Asia}

\section{Japan}

Japan has been a significant source of foreign aid and investment for Myanmar, reflecting the close relationship between the two countries since the Second World War, when over 100,000 Japanese soldiers lost their lives there. This close 
relationship is reflected in the several high-level visits to Myanmar since 1997: by Japanese State Secretary for Foreign Affairs, Masahiko Koumura (1997); by Minister for International Trade and Industry, Takashi Fukaya (2000) and by Minister for Foreign Affairs, Yoriko Kawaguchi (2002). Japan's support leant credibility to the Myanmar government's efforts to improve the living standards of the people. In 2001-2, Japan provided USD 29 million for maintenance on the Baluchaung No. 2 hydroelectric power plant, built with Japanese aid. Ongoing assistance has been provided by Japan in the form of debt-relief grants, aid for agriculture, forestry, education, health (particularly HIV/AIDS, tuberculosis and malaria control and prevention) grass-roots projects, poverty-alleviation measures, information and communication technology equipment and training, extension of Yangon International Airport and building of a new headquarters in Yangon for the Myanmar Maternal and Child Welfare Association (MMCWA), the largest grass-roots, domestic non-government organization. Japan has been Myanmar's primary source of international aid totalling, as of November 2002, 1.29 billion yen in grants and a further 770 million in technical cooperation. ${ }^{23}$ In April 2002, 7,920 million yen was provided for medical equipment for hospitals in Yangon. Two new projects launched in November 2002, the project for afforestation in the central dry zone (4,800 million yen) and the project for human resource development scholarships (2,660 million yen), indicate Japan's focus on capacity building and sustainable development in its overseas aid programme. In 2002 also, Japan provided USD 1.2 million for drug eradication in Wa State, in Upper Myanmar. In addition, the non-government Sasakawa Foundation funds many capacity-building projects in Myanmar, and Japanese NGOs work in rural areas on grass-roots projects aimed at assisting villagers to improve their standard of living.

Japan has thus been doing a great deal to contribute to the development of Myanmar's socio-economic fabric and in November 2003 conducted a three-day workshop in Yangon on industrial relations. (New Light of Myanmar, 27 November 2003). It was thus with some consternation that Myanmar heard Japan's declaration, after the 30 May 2003 incident, that no further assistance would be rendered until Daw Aung San Suu Kyi and her comrades were released. Although this condition has been only partially fulfilled, Japan has recommenced its humanitarian assistance particularly for HIV/AIDS prevention and control, in view of the dire need in this impoverished country.

Japan, which has large investments in all the ASEAN economies, joined the ASEAN security pact in November 2003, further underlining the region's perspective that its search for security is being projected through the economic lens (The Australian, 18 November 2003). The 11-12 December 2003 summit in Tokyo which climaxed the ASEAN-Japan Exchange Year, saw Japan initiate an ASEAN free-trade agreement to be implemented by 2012 along similar lines to that between ASEAN and China. At this summit, the objective of which was to set in train initiatives to narrow the development gap between the four newer members of ASEAN - Myanmar, Laos, Cambodia and Vietnam - and the more prosperous older members - the former Myanmar Prime Minister, General Khin Nyunt, took the opportunity to have private discussions with his Japanese 
counterpart, Prime Minister Junichiro Koizumi. Initiatives arising from this summit included Japan's gift of 100,000 scholarships to ASEAN countries for study in Japan; training in information technology by Japanese specialists, and assistance to improve educational standards. The linkages between economics and security are underpinned in the participants' intention to expedite the currency swap agreement first signed between Japan and ASEAN in 1999 to assist in stabilizing ASEAN economies and strengthen their capacity to withstand financial crises similar to that of 1997; the proposals by Japan to develop a regional capital market; provision of coast-guard facilities by Japan to counteract transborder crime and piracy; and a network of government officials to assist in coordinating regional security (Myanmar Times, 8-14 December 2003).

\section{South Korea}

Like Japan, South Korea also is an important trading partner of Myanmar with substantial investment in the country. There is a strong empathy between the two countries from the time when the former South Korean president, Chun Do-Whan, narrowly escaped assassination by a North Korean terrorist group, when visiting the Aung San memorial in Yangon. Several members of the South Korean cabinet were killed. Since then, South Korea has evolved from military rule to a functioning democracy with a strong civil society, a development which has gone in tandem with its economic development. Its example might encourage Myanmar to try to follow a similar path. As a good international citizen, South Korea maintains very friendly relations with Myanmar. On 21 November 2003, the South Korean Ambassador to Myanmar was present at the ceremony when the President of Daewoo International Corporation, Mr Tae-Yong Lee, and VicePresident, Mr Chae-Moon Rim, and members donated medicines to the Myanmar Ministry of Health. The ceremony was held at the meeting hall of the National Health Committee in Yangon attended by the Minister for Health, the Deputy Minister, directors-general of departments, the deputy directors-general, rectors and medical superintendents (Myanmar Information Committee, 22 November 2003). A South Korean trade delegation subsequently arrived on 26 November (New Light of Myanmar, 27 November 2003).

Against this backdrop of diplomatic initiatives and economic policy, articles in the Far Eastern Economic Review (FEER) in late October 2003 suggesting that Myanmar is seeking to establish a nuclear programme with the assistance of materials and expertise from North Korea, need to be treated with caution. Not only would nuclear China and nuclear India be likely to fiercely resist any attempt from impoverished Myanmar to establish nuclear capacity, on their back-door step, but the obvious question should be asked, who would pay for such a programme? Should Myanmar proceed down the path of acquiring nuclear capacity, such a policy would be likely to disrupt the development of the supportive regional relations within ASEAN which Myanmar's government has been assiduously cultivating. Such a programme would be at odds with the logic of Myanmar's international policy and its search for security through building friendly alliances with a 
politico-economic nexus. As signatory to the Zone of Peace, Freedom and Neutrality (ZOPFAN) and Southeast Asia Nuclear Weapons Free Zone (SEANWFZ) accords, Myanmar would be courting the displeasure of its ASEAN neighbours and placing at risk the regional security policy it has been carefully constructing over a number of years. My discussions in Yangon in February 2004 on this issue elicited forthright denials, and although Selth (2002) is a little ambivalent about Myanmar's plans to acquire nuclear capacity, it is my view that this construct is part of the Western-originated international campaign against the country, and without foundation in logic or fact.

\section{Contemporary relations with Australia - the fruits of engagement}

Under the Liberal-National Party coalition government of Prime Minister, John Howard, since 1997 Australia has fostered an engagement policy with Myanmar on the basis that the previous sanctions policy was not conducive to supporting the country's evolution to democratic governance. Officially, the Australian government provides some funds for humanitarian and health assistance, especially for HIV/AIDS, and for educational assistance to the refugees in camps in the border areas with Thailand. This funding in financial year 2003-4 amounted to some AUD 7.5 million inclusive of funding for the government-sponsored human rights workshops, which are delivered to middle and senior ranking civil servants, educators and police. These workshops were suspended pending Daw Aung San Suu Kyi's release. At the time, Foreign Minister Alexander Downer stated that they would be resumed once that condition had been fulfilled.

Such funding for health and humanitarian projects was markedly increased in the May 2005 Australian government budget, and focussed on several community, grass-roots level HIV/AIDS prevention and control projects, and health-care improvement projects for vulnerable groups in the border areas of Eastern Shan States, Rakhine and Chin States and on the Thai-Myanmar eastern border. This humanitarian aid is delivered through INGOs such as the Australian Red Cross, Medecins San Frontieres Australia (working in conjunction with its Dutch counterpart), Care Australia and the MacFarlane Burnet Institute. Australia also contributes over AUD 45 million through various regional initiatives in conjunction with ASEAN, as well as contributing to the UNODC drug-suppression programmes. These regional initiatives take as their baseline the improvement of Myanmar's socio-economic fabric through assisting with prevention of human trafficking and drug-control programmes. A special two-year programme called Childwise, which commenced in 2004, provides assistance through UNICEF in building capacity to prevent child sexual exploitation in regional tourism destinations. ${ }^{24}$ By such initiatives, Australia is making a practical contribution to poverty alleviation among Myanmar's vulnerable social and ethnic groups.

In other areas, the Australian Centre for International Agricultural Research (ACIAR) has been cooperating on agricultural assistance to Myanmar to help in improving seed quality and yield per hectare. In accordance with this humanitarian 


\section{External relations in regional context}

perspective, various Australian universities also assist with educational development and special programmes in the health and agricultural sectors. Much needed international assistance with the development of Myanmar's educational sector and economic capacity is presently available through the Australia-IMF Scholarship Program for Asia which aims to train government and Central Bank officials from 'economies in transition' in macroeconomic management. Together with citizens of Cambodia, China, Lao PDR, Mongolia and Vietnam, Myanmar citizens are eligible for scholarships under this innovative programme.

Australia's engagement policy is in marked contrast to that of the US, UK and EU and is a reflection of geopolitical issues, and the close relationship between the two countries arising from the Second World War. However, Australian trade and investment with Myanmar are minimal, amounting to only around AUD 10 million per year. Given the new economic and investment strategy being pursued by Myanmar's closest neighbours, it is possible that Australia may follow suit, as a practical means to alleviate poverty and develop that capacity for pluralistic democratic governance within Myanmar which all sectors - international and domestic - claim they wish to see evolve. Australia has thus eschewed what Nossal (1994: 29) identifies as the 'rain dance' policy of symbolic sanctions which 'makes participants feel better, but nothing of substance is actually accomplished'. By resisting the call of exile groups in the US, UK and EU to impose economic sanctions on Myanmar because of its alleged human rights violations and slow return to democratic governance, Australia implicitly recognizes that the sanctions approach 'ends up punishing entirely the wrong people' (Nossal 1994: 264). Australia has instead taken a practical approach to improving the economic, social and political 'well-being' of Myanmar's deprived populations. ${ }^{25}$

\section{Conclusion}

Myanmar's regional security enhancement strategy could therefore be seen as an amalgam of both the realist 'balance of power' and constructivist 'security through cooperative partnerships with regional neighbours' paradigms. Both approaches, however, are focussed on state and regime security. The challenge for Myanmar will be to integrate the socio-economic and political changes needed to enhance human security with its traditional indigenous approaches to state and regime security. To put the dilemma another way, the challenge will be for the state to acknowledge that its own future security is predicated on its capacity to deliver the reforms necessary for implementation of human security - a commitment to the protection of human rights in accordance with international standards; a commitment to transparency and participative practices in governance; a commitment to establishing an accountable and independent judiciary and a commitment to pluralistic democratic norms. Myanmar's regional security enhancement strategy - winning friends and influencing regional governments - will need to integrate these fundamental platforms of human security into its indigenous state/regime framework, if its objective of achieving holistic security is to deliver on its expectations. 


\section{Myanmar and the West \\ Sanctions, engagement and \\ security}

\section{Introduction}

Myanmar's relations with the West - the EU, the UK, and the US - since 1988 have been fractious and conflictual, underpinned by policies of evertightening economic and financial sanctions, public vilification campaigns aimed at Myanmar's military leaders by an assortment of international NGOs (Amnesty International, Human Rights Watch, Christian Science Monitor, International Committee of the Red Cross, the ILO), externally based democracy activist groups and cyber attacks from the Burmese Diaspora. Despite repetitive themes enunciating the suffering and endemic poverty of the majority of Myanmar's citizens, these strategies have been ineffectual in achieving their alleged intentions of restoring democratic governance to the golden land of Myanmar, although millions of dollars have been applied to their activities by such sources as the National Endowment for Democracy and George Soros' Open Society Foundation. In mid-2005, Guy Horton, a friend of the late Michael Aris, the Oxford academic who was married to Burmese opposition leader, Daw Aung San Suu Kyi, compiled a 600-page document detailing the alleged 'genocide' by the Burmese military government against ethnic rebels on the eastern border with Thailand during the decades of civil war. He planned to present the document to the UN as part of the Burma UK campaign to prevent Myanmar from assuming the ASEAN chairmanship in 2006. Even Lee Kuan Yew (Straits Times, 11 August 2005) looked to the possibility of Myanmar's population, motivated by comparison with the greater wealth enjoyed by citizens of Thailand, to rise against their military government, a comparison immediately refuted by a Burmese international citizen, Ma Thanegi (Free Burma Coalition, www.freeburmacoalition.org, accessed 16 August 2005), in drawing attention to the very different world view and values of Myanmar's people. Neither poverty, nor decades of oppressive domestic policies, nor human rights abuses, nor Western-based charges of alleged genocide against various ethnic minority peoples, has led to the mooted civilian displacement of the Burmese/Myanmar military government which might have been expected, and indeed has occurred in other formerly authoritarian polities.

As Mary Callahan (2003) has asserted, Myanmar has defied the regional trend to replace overtly military dictatorships with apparently civilian administrations, 
although it is sometimes difficult to identify any 'full' or 'mature' democracy in the Asian region. More than 50 years after its hard-won independence from its former colonial master, Britain, military governance in Myanmar remains as resilient as ever, underpinned by policies of nationalism, self-reliance and a determination to protect its sovereignty from foreign (i.e. Western) intrusions. The latest contretemps over Myanmar's turn to chair ASEAN in 2006 only served to measure how far apart are the two very different world views - that of the industrialized and democratized West, and that of mostly agrarian, authoritarian, 'medieval' Myanmar, which Lee Kuan Yew, in the article cited earlier, has pointed out cannot 'stay frozen in time'. The witch-hunt going on for the supporters of the displaced reformist Prime Minister, General Khin Nyunt, who might have been able to broker the needed changes in Myanmar's governance, to bring it out of the medieval world of personalized power and patron-client relationships into the modern world of people power, only serves to underscore how frozen in time Myanmar's systems of governance are.

Frozen in time or not, the military leadership under Senior General Than Shwe seems more entrenched in power than ever before, and even less inclined to be influenced by the international community than in the previous 5 years. The question needs to be addressed: Is this the result of the policies pursued by the West towards Myanmar? Have these policies been counterproductive in achieving an evolution from military to democratic governance in Myanmar? It is perhaps timely to observe that during the Cold War which coincided with the high tide of military rule in Burma, 1962-88, when the late General Ne Win was pursuing his avowedly anti-Communist policies in the context of civil war and widespread ethnic insurgencies, no such Western sanctions were applied to the country; yet human rights abuses were rampant, perpetuation of poverty for most citizens was official policy under the Burma Socialist Program Party (BSPP) which systematically eliminated the middle classes, and no challenge to military governance from any sector was countenanced. Some of those who lived through that era have told me that everyday life then was even harsher than it is now, despite the more than 15 years of Western sanctions.

So what triggered the change in Western policy? Clearly not the fact of continuing military governance alone, as Western governments - the USA, UK and the EU - maintain normal foreign relations and trading arrangements with a range of countries which are either under military dictatorship (e.g. Pakistan), or not democratic (e.g. The PRC). Indeed, if the sanctions 'sender' countries and those who support the sanctions policies in their bureaucracies were to interact only with those countries which they considered 'true' democracies, they would have relations with very few countries. Along similar lines, at a recent conference in Malmo, Sweden, John Badgley argued,

Burmese thrive on rumors about family fortunes made through links to Wa drug lords, Chinese syndicates, and Thai politicians. But is the quest so different from what one finds in neighboring societies - the Philippines, 
Indonesia, Sri Lanka, Laos, Thailand, Vietnam and Cambodia - countries not suffering from sanctions, despite corruption and violence tolerated within. Only Burma must endure that substantial obstruction of economic sanctions. Why? Do sanctions really ameliorate the aborted 1990 elections, Aung San Suu Kyi's house arrest, and the imprisoned opposition activists?

(Badgley 2004a: 7)

Since the answer to this rhetorical question is so clearly 'No!' we must ask why this policy persists. In the same essay Badgley (2004a: 4) asserts, 'sanctions are a form of coercion, like an invasion, designed to humiliate and threaten the regime, no matter the pain caused the common people'. If effect, there is no expectation in the sender countries that sanctions will achieve the stated aims of bringing about regime change, pluralistic democratic governance or installation of Daw Aung San Suu Kyi as premier of Burma/Myanmar. Sanctions are merely a cynical exercise in international theatre. Daw Aung San Suu Kyi and her movement are as much their victims as are the long-suffering people of Burma/ Myanmar.

In the sanctions decade of the 1990s the export of Western-style democracy and the human rights framework became reified during the Clinton Administration, but even this does not sufficiently explain the hard-line, myopic approach to Myanmar; despite the prominence of the democracy and human rights discourse in international affairs since the 1990s, there are again many exceptions, Saudi Arabia being a notable one. Nor is it sufficient to point to the timely development and efficiency of the World Wide Web in promoting the antiMyanmar discourse, or the iconic statue of the imprisoned opposition leader, Nobel Peace Prize winner, Daw Aung San Suu Kyi, in producing the vehement isolationist policies which Myanmar's enemies advocate. It is necessary to seek some other hitherto elusive element in fathoming the continuance (now more than 15 years) of what is so clearly a zero-sum game in the Western sanctions policies applied to Myanmar (and despite the misplaced triumphalism subsequent to Myanmar foregoing its turn to chair ASEAN in 2006).

In the words of Myint Shwe (Bangkok Post, 18 April 2004), sanctions intended to bring about regime change in Myanmar have missed their mark. Sanctions, he avers, have become 'part of the problem' rather than 'part of the solution as they were meant to be'. Yet, given the domestic political considerations which keep sanctions in place in the sender countries, and the lack of progress towards political reform in Myanmar (the 'target' country), Western economic and financial sanctions are unlikely to be lifted in the near future. Both sides have taken up positions from which it is impossible to move without immense loss of face entailing loss of political capital and support from their domestic constituencies.

Myanmar fits the 'war of attrition' model of McGillivray and Stam (2004: 159) in which sanctions continue for a long time because both the sender and target states, for reasons of domestic politics, quite simply 'prefer their continuance' (ibid.). In this model, Myanmar is one of those target states, which prefers to 
'bare [sic] the cost of sanctions indefinitely' (ibid.) rather than comply with the sender's (foreign) demands to change its system of governance. Sanctions, in Myanmar's case, are intended to bring about regime and leadership change. Though this approach has manifestly failed to bring about any policy concessions in the target state, yet, as MacGillivray and Stam (2004: 155) observe, sanctions have persisted 'long after it is clear that they are ineffective foreign policy tools'. In Myanmar's case, sanctions have been not just ineffective, but counterproductive, stimulating nationalistic resistance to foreign-instigated demands, autarkchic domestic policies, and rent-seeking socio-economic patterns which impede the development of a robust civil society without impacting adversely on the leadership. Sanctions, perversely, are welcomed; they shore up national identity in this post-colonial polity with its legacy of profound xenophobia. In the 'sanctions decade' of the 1990s when sanctions were said to be a preferred instrument of Western foreign policy obviating recourse to war, yet few achieved even partial success. ${ }^{1}$ As Mack and Khan (2000) argue,

The most damaging charge against sanctions, particularly comprehensivesanctions, is that they impose widespread suffering on ordinary people, while leaving the regimes they target not only relatively unscathed, but also sometimes enriched and strengthened. In part as a consequence, almost all studies today argue for one variant or other of what have come to be known as 'smart sanctions', i.e. those sanctions intended to target regimes, not peoples. The effect, though not the intent, of a number of recent sanctions regimes, most notably in the case of Iraq, has been the reverse. Peoples have been harmed far more than regimes.

(Mack and Khan 2000: 280)

At the heart of conventional sanctions theory lies a fallacy; this presupposes that the economic hardship inflicted by sanctions on the citizens of the target state will cause them to either rise up against their (authoritarian) government, or pressure it for changes. On the contrary, Mack and Khan assert, 'Those who bear the brunt of the sanctions have no power to influence policy; those in power tend to be relatively unaffected' (Mack and Khan 2000: 281). Their perspective is shared by Pape (1997) and by Nossal (1994: 266) who asks why should vulnerable populations welcome those foreigners who have been instrumental in causing deterioration in their well-being? The 1988 uprising in Burma, it should be noted, occurred prior to the imposition of Western sanctions; and was instigated initially in response to fears of further demonetizations by the almost defunct BSPP, that is, an internally generated set of dynamics, not an externally sourced node of political ideologies. How vulnerable populations really feel about those who originate and implement economic sanctions may be gauged by the bombing of the UN building in Baghdad resulting in the deaths of Sergio de Mello and many of his colleagues. Sanctions thus remain a 'feel-good' policy by the sender state which wishes to send a message of censure, when substantial economic resources in the target state are not at risk. 
In view of the impasse in international policy towards Myanmar, in November 2001, the Swedish Ministry of Foreign Affairs in conjunction with the Department of Peace and Conflict Research at Uppsala University initiated the Stockholm Process on the Implementation of Targeted Sanctions (SPITS); the subsequent 'Stockholm Report' was presented to the Security Council on 25 February 2003. Under this process, in April 2004, Wallensteen, Staibano and Eriksson of the Department of Peace and Conflict Research, Uppsala University, presented their short essay, 'Routes to Democracy in Myanmar: the Uppsala Pilot Study on Dialogue and International Strategies'. This study examines the possibilities for a modified approach which could include targeted sanctions and international involvement such as the appointment of an EU special envoy, to mediate the democratic dialogue process in Myanmar between the government, the opposition NLD and the ethnic minority groups. There is of course, already a UN Special Envoy, the Malaysian diplomat, Tun Razali Ismail, whose best endeavours have proved ineffective in moving the dialogue process forward, and whom, the SPDC has made clear, is now not welcome in Myanmar. It is doubtful that yet another 'special envoy' would be any more successful. That this dialogue, since the 18 October 2004 removal of General Khin Nyunt and his faction, seems to be irreparably stalled, perhaps serves to underline the necessity for reviewing present Western international policy towards Myanmar. In the words of veteran Thai diplomat, the former Foreign Minister, Surakiat Sathirathai, 'sanctions do not lead to democracy'; instead they 'create hardships for the poor' whilst leaving the leadership untouched (Bangkok Post, 18 April 2004). Being closest to the issues, and in view of their own history, Thailand is sure that economic sanctions are indeed part of the problem, not the solution.

These issues were canvassed in depth in the NBR report, No.15, released in March 2004, Reconciling Burma/Myanmar: Essays on U.S. Relations with Burma, compiled by John Badgley and six other noted international scholars on Myanmar. Their conclusions assert that Western economic sanctions, far from encouraging the evolution of Myanmar to sustainable democratic governance, have impeded that evolution; they have 'undermined Western influence in the country by making Myanmar increasingly impervious to the interests of Western nations' (Badgley 2004: 8). Impervious also to Western blandishments, it might be added. On the contrary, the report asserts 'Involving states and societies in the web of international trade and finance is the best way to link them to the norms of transparency and the rule of law' (ibid. 9). Those who believe in the efficacy of free trade as a critical element in an evolving robust civil society ought to follow the logic of their own convictions, and reverse the sanctions policy, if indeed they wish to see Myanmar evolve to democratic governance. As Nossal asserts, 'Economic sanctions imposed for human rights violations end up punishing entirely the wrong people' and are 'a blunt and crude tool of statecraft' (Nossal 1994: 264) intended to reassure the diaspora of the target country that the sender abhors its behaviour, but without any expectation of substantial achievement - in effect 'rain dancing' as far as changing the behaviour of the target state is concerned, but diminishing the well-being and life capabilities of its vulnerable populations. 
How to cut the Gordian knot, without appearing to either surrender to the SPDC, or to give the appearance of approving its human rights violations, has been at the heart of discussions in several international venues. Most recently, the EU appears to be moving closer to the position of acknowledging that renewed international humanitarian aid and economic investment are essential first steps to alleviate the endemic poverty in Myanmar. They are also essential steps in starting to build a critical mass of population able to support sustainable future non-military governance in a polity which not only does not have a tradition of civilian control of the military, but within which the field/staff officer rivalry and co-relative disunity amongst the opposition forces have had serious flow-on consequences for domestic governance. The real battle inside and outside Burma/ Myanmar since 1988, as Martin Smith (1991, rpt. 1999: 422) observed has been for control of the transitional process, and it has been this site that the Burmese armed forces are still very reluctant to relinquish. They are still conditioned by the post-independence mindset which projects them as the saviours of the country against internal and external forces of disintegration. Smith captures the time lag afflicting Burma/Myanmar

[I]n the post-Cold War era, when the values of democratization and civil society were being promoted by much of the international community, the political relationships and language inside Burma were still very loosely charted.

(Smith 1991, rpt. 1999: 424)

How loose can be gauged by the far-reaching purge of General Khin Nyunt and his faction on 18 October 2004 - said to encompass over 8,000 people; and the preceding move against some 14 regional commanders, senior officers and former ministers in November 1997. Whilst the now-stalled National Convention process has been overtly structured around a continuing major role for the military in any future constitutional form of government, the precise distribution of power at the top echelons is not transparent. Larry Jagan (Bangkok Post, 7 July 2005) for instance, now seems to be suggesting that the people should put their faith in Vice-Senior General Maung Aye to lead the national reconciliation process with the NLD. Jagan may be attempting to foster a fall out between Senior General Than Shwe and the number two in the top leadership group. In this situation it seems judicious for the international community to move more precisely to privilege the majority of Burma/Myanmar's vulnerable populations, Burman and ethnic minority alike, rather than the minority few in the senior military cadres. An official policy within the international community for an increase in humanitarian aid, developmental assistance and economic investment would start to redress the imbalance in the international sanctions discourse and begin to recognize that the 'art of the possible' (Taylor 2004a) in Myanmar needs to be designed around incremental steps which will gradually empower the majority of its peoples. 


\section{Myanmar and the EU}

Whilst the EU imposed sanctions on Myanmar since 1996, including restrictions on travel visas for members of the government and senior officials, an arms embargo and freezing of assets, indications of a move in the EU position and of that of some of its members in recent years suggests increasing acknowledgment of the need to explore alternate approaches. The EU in 2001-2 promised contributions of 5 million Euros to assist with HIV/AIDS programmes under the UN Joint Plan of Action; and in 2002 participated in the ASEM with Myanmar represented. The previous meeting had not taken place when Asian governments refused to hold it in view of EU insistence that Myanmar not be represented. Most recently, despite vehement opposition, ASEAN was able to win the argument that Myanmar should be able to participate in the 8-9 October 2004 ASEM summit in Hanoi, if the 10 newly admitted EU members were to participate. EU-ASEM Dialogue partners, China, Japan and South Korea also participated in this summit. Membership of ASEM has been an important step for Myanmar in being seen as a fully fledged member of ASEAN, the ARF and their international alliances. ASEM now includes all $25 \mathrm{EU}$ members and all 10 ASEAN members. Even renewed EU travel sanctions in late 2004, of little practicable effect, could not diminish the sense of ASEAN triumph on this fiercely fought issue. ${ }^{2}$

Amongst individual EU members, France built and equipped a hospital in Mandalay in 2001-2; Germany has some trade and investment in Myanmar and has granted a number of scholarships to assist with Myanmar's educational development; and in November 2003 Hungarian Deputy Foreign Minister Andras Barsony declared that the EU's sanctions were not helping to bring democracy to the country. In Bangkok for bilateral discussions with former Thai Foreign Minister, Surakiat Sathirathai, Mr Barsony said, 'changes must come through permanent dialogue, not by isolation' adding that sanctions would not succeed in making any targeted country change its ways. ${ }^{3} \mathrm{Mr}$ Barsony did not say directly whether he supported Yangon's seven-point plan to return Myanmar to democracy, but stated that every attempt to bring the people of Myanmar closer to real democracy should be supported.

Barsony's stance proceeds from the viewpoint that bringing Myanmar within the socialization processes of the EU-ASEM framework opens the possibility of greater influence being brought to bear on the country's leadership to adapt to international norms, than by isolating it within a symbolic sanctions regime. A seven-member senior delegation which included the new Myanmar Foreign Minister, U Nyan Win, and his deputy Minister, U Kyaw Thu, attended the 8-9 October 2004 EU-ASEM summit in Hanoi. In mid-2005, partly in response to an independent report to the EU by academics, Robert Taylor and Morten Pedersen, and despite the furore the report evoked from anti-government activist groups based outside Myanmar, as discussed earlier, the EU gave indications of reconsidering its position on resumption of humanitarian aid to Myanmar in recognition of the parlous state of the country's socio-economic fabric. As Taylor and Pedersen have suggested, it is timely for the European Commission (EC) and 
EU Member States to develop an assistance strategy for Burma/Myanmar with associated funding, which will assist to repair the ravages to the country's socioeconomic fabric, disassociate the EU from the hard-line US position and consider appointing a senior EC representative tasked with ensuring that the assistance strategy is appropriately implemented according to EU guidelines (Taylor and Pedersen 2005: 21).

Taylor and Pedersen's recommendations build on Martin Smith's (1991, rpt. 1999: 436) timely reminder that Daw Aung San Suu Kyi’s call for economic sanctions 'did not always win countrywide support, especially among those who believed that international engagement and development were, by contrast, the catalysts that would lay the foundations for change in such an isolated country as Burma'. Smith highlights the fact that the call for sanctions and trade boycotts has hurt the NLD within certain elements of what might otherwise have been its natural domestic constituency. In recent years, there have been welcome suggestions in the NLD leader's statements that she is ameliorating her previous opposition to humanitarian aid. Taylor and Pedersen's report thus gives substance to the art of the possible; it privileges rebuilding the socio-economic fabric ahead of, and not as a condition of, political change. It is therefore significantly distinguished from the February 2004 report of the US State Department, 'Identifying Resources for the Reconstruction of Burma' which will entertain the provision of developmental assistance only after the SPDC 'is removed from power' - by what agency, the State Department's report does not specify. ${ }^{4}$

A change in EU policy would therefore be a very significant first step towards empowering Myanmar to adopt that pluralistic democratic governance which all sides are said to desire, but which would entail a very significant loss of face, and possibly funding, for some of the diaspora who have been intransigent, and virulent, advocates of sanctions despite the harm done to vulnerable populations amongst their own countrymen. The imperative of the report, The Responsibility to Protect (see Chapter 1), 'first do no harm', in Myanmar's case, ironically has been subverted by both the government and the anti-government groups. This is the dilemma for Myanmar's vulnerable populations.

On the other hand, resumption of humanitarian aid by the EU and support for rebuilding the socio-economic fabric in Myanmar would be within the international norms - 'the responsibility to protect' and to 'do no harm' to vulnerable populations - which are at the heart of the human security concept. Although sanctions have been invoked in response to violation of key human rights norms, they have had the effect of eroding the very rights they are allegedly intended to uphold. By their imposition, the 'right to development', the right to robust education and health systems and the right to make a decent living have been jeopardized - rights which enhance the 'capabilities' of the population at large to participate in pluralistic democratic governance. The 'moral credence' (Drezner 2000: 77) of the sender country too is impugned by the adverse effects its sanctions policy has on already vulnerable populations. Where sanctions revolve around a set of norms, not necessarily shared by the target country, but which, on the contrary, invoke the highly prized norm of preservation of national 
sovereignty, especially in a post-colonial polity imbued with authoritarian governance systems, the intention to sustain resistance to the sender sanctions in perpetuity, is increased. As Drezner argues,

[T]hough the use of norms can strengthen the resolve of the sanctioning coalition, it also allows target elites to construct an identity based on their opposition to the proclaimed norm .... Target states can use their defiance of global norms as a wayof counteracting the enhanced resolve of the sanctions coalition....

[I]n appealing to a consensual norm, the sender also endows the demand with an all-or-nothing quality, increasing the likelihood of the target country standing firm.

If the EU really moves to implement a policy of resumed humanitarian aid to Myanmar and developmental assistance to rebuild its socio-economic fabric, it would implicitly acknowledge the ineffectual nature of present Western international policy on Myanmar; and, also implicitly, the comparatively greater efficacy of the ASEAN norm of 'quiet', behind-the-scenes diplomacy. ${ }^{5}$ Similarly to when Myanmar joined ASEAN in 1997, the country's membership of ASEM will increase its exposure to international norms, create more opportunities for the socialization of its elites through their participation in international fora, and enable EU policy makers to enhance their own avenues to influence the leadership of Myanmar to move the country closer towards international expectations of how a modern state should operate. This can only be beneficial for the millions of Myanmar's citizens presently enmired in poverty. If the Millennium goals, the forgiving of third world debt initiative and the UN's resolve to make poverty alleviation a reality for the over 1 billion people who live on USD1 per day, are to have any significance, it is time for public recognition that a different approach to Myanmar is required; that sanctions impede these goals and should be lifted so that rebuilding Myanmar's socio-economic fabric can proceed. The EU will then have participated in the evolution of a more civil society in Myanmar.

\section{Myanmar's relations with the US and the UK}

For over 15 years, since the failed democracy uprising of 1988, Myanmar's relations with the US and the UK have been permeated by mutually vitriolic exchanges reminiscent of those which punctuated the Cold War era between the communist and non-communist blocs. As Drezner notes, 'The coercion of adversaries is far more public than the coercion of allies' (Drezner 1999: 309), because there is little to be lost in the way of economic or political leverage. Both sides know it is a zero-sum game, and are content for the war of attrition to continue. Nevertheless, since the sanctions decade of the 1990s, economic coercion has been a key feature of US foreign policy, driven by the twin poles in the neoliberal institutionalist paradigm that economic interdependence fosters cooperation between states because it increases the costs of defection and, secondly, 
that strong economic sanctions 'provide an incentive for cooperation' (Drezner 1999: 9). For reasons of domestic politics, exemplified by Senator Mitch McConnell and the anti-Burma bloc in Congress, the present NeoConservative ascendancy in Washington has chosen to continue these twin policy planks, despite the general realist tendency to put little faith in economic statecraft. By doing so the US implicitly adopts the position that symbolic sanctions have a moral, public policy value for the special interest groups in its own constituencies; it has chosen to privilege these groups and their perspectives over the welfare of the majority of Myanmar's people, because the economic costs of doing so are assumed to be minimal. ${ }^{6}$ As Lisa Martin has noted, while US sanctions against Myanmar (and other countries, e.g. Latin America) allegedly derive from its policies of exporting respect for human rights, violations of human rights were systemic in its authoritarian governance 'long before the U.S. considered imposing sanctions' (Martin 1992: 248).

The ever-tighter sanctions imposed on Myanmar by the US and UK since 1988 have not brought about the collapse of the military government or the collapse of Myanmar's terms of trade. Myanmar has found no difficulty in locating and developing alternate markets amongst its Asian neighbours, many of whom openly state their opposition to the sanctions policy as a tool in fostering improved governance in Myanmar. ASEAN states earnestly desire Myanmar to change its ways; to put its domestic house in order, and move towards adopting international norms; they are conscious, as Lee Kuan Yew noted, that domestic unrest in Myanmar will have serious spillover effects in neighbouring states. Increasingly, Myanmar's neighbours point to the adverse impact US and UK sanctions have on its vulnerable populations. Not only have Western sanctions resulted in the 'rally round the flag' syndrome within Myanmar, but also a version of this syndrome is becoming obvious amongst some ASEAN countries, impacted as they were by the 1997 financial crisis. Western economic sanctions against Myanmar have been counterproductive to achieving their stated aim. The activities of US- and UK-based exile communities in forcing companies to withdraw their operations from Myanmar results, in the short term, in unemployment for the very vulnerable at the bottom of society whose poorly paid factory jobs have meant the difference between eating and not eating. The sanctions have no effect on Myanmar's ruling elites whose substantial business interests are not aligned to US investment and hence insulated from its policy of economic coercion; they have stimulated autarchy and nationalism, and a strong desire to resist the pressures from Western-based exile groups perceived to be working to the advantage of neocolonial interests. As an overwhelmingly agrarian country operating on a largely subsistence economy, with little exposure to the international political economy, not economically dependent on any Western country, Myanmar's vulnerability to sanctions is slight. Drezner (2000: 76) is surely correct in arguing that greater economic interdependence between the sender and the target may have increased the likelihood of sanctions achieving the desired change in domestic policies within a country such as Myanmar. 'For sanctions to work' he states, 'the primary sender must have the ability to alter the target 
country's terms of trade regardless of the targeted regime's efforts to substitute' alternate markets. Given its geopolitical situation and cooperative relations with emerging economic giants, China and India, these conditions are not present in Myanmar. Myanmar's leadership can in effect shrug off Western sanctions.

An example of the counterproductive consequences of economic sanctions may be seen in the punitive measures imposed by the US following the Depiyin incident in May 2003. Shortly thereafter, in response to domestic demand and international outrage, President George W. Bush signed into law the Burmese Freedom and Democracy Act 2003. This legislation closed down US trade in textiles with Myanmar which had netted the country around USD 300 million per year in foreign exchange. There was some evidence that discontinuance of this trade with the US initially impacted adversely on Myanmar textile exporters, and forced the closure of factories, at least some of which had connections to the military leadership. The resultant loss of jobs to lowly paid women in this sector increased the economic hardship for these already vulnerable women, forcing them into prostitution to feed their families. To address this problem, Myanmar has since then developed alternate markets in India, China and Thailand which have resulted in the reopening of the closed factories and revival of employment opportunities for these women. In this case, the sanctions applied were not only unable to bring about a change in the domestic policies of the target country, but also increased the animosity towards the sender country. Moreover, the loss of economic opportunity, trade and market share which formerly accrued to the US was quickly and happily taken up by its competitors in the world trading system, the emerging economic giants, India and China. A similar pattern of lost economic opportunity, which can be equated to lost capacity to influence the policy directions of Myanmar's government, is becoming apparent in other sectors, most notably the energy sector with the recent bid by China for UNOCAL, the oil company which has up to now had substantial interests in Myanmar. Sanctions, in effect have been symbolic, a function of US domestic politics, without the leverage to bring about the type of political changes their proponents advocate. Conversely, greater economic leverage may have resulted in greater opportunity to bring about policy change in Myanmar. In their analysis of the relationship between use of economic sanctions and domestic institutions, Lektzian (2003: $655)$ concluded that, 'States are more likely to sanction a nation with whom they have low levels of trade than a nation with whom they have extensive trade ties' since sanctions are a 'two-edged sword' which 'entail losses for the sanctioning state as well as the target state'. Moreover, in autocracies whose 'leaders are generally beholden to a small cadre of elites for their political survival, sanctions ... may lead to a general decline in national welfare with little chance of eliciting the desired policy change' (Lektzian 2003: 649). Thus the zero-sum game can continue indefinitely.

The US has also imposed financial sanctions on Myanmar with similar lack of substantial impact. Under President Bush's Burmese Freedom and Democracy Act 2003, provision of financial services to Myanmar was prohibited, resulting in credit card services by American Express, Mastercard and Visa, being withdrawn. 
These measures had temporary impact on the tourist industry and trade sectors. Freezing of (almost non-existent) Myanmar assets in the US netted a mere USD 700,000 . Since then, Myanmar has put in place alternate means of conducting its international transactions through the good offices of neighbouring states and conducting at least some of its international trade in Euros. In addition, remittances from Myanmar nationals living abroad, required by law if they are to keep their citizenship and passports, have also reduced the vulnerability of the country to financial sanctions. Myanmar thus exhibits the classic matrix of circumstances in which economic and financial sanctions are unlikely to bring about the policy changes which the sender country decrees (Oudrat 2000: 105-27). Moreover, continuance of the unilateral sanctions provides opportunity for the target country to gain a propaganda advantage by pointing to actions of the sender country in delaying its evolution to a sustainable democracy. After renewed US sanctions in mid-2004, the Myanmar Times (12 July 2004) editorialized, 'It is so obvious that America will definitely benefit from a democratic Myanmar, yet Washington ignores our invitations to work constructively towards this goal' whilst 'decisions taken in Washington are hampering efforts in Myanmar to develop the economy, fight the drug trade and play a bigger role in the international community'.

Within the US this perspective is shared by Professor Jeffrey Sachs, Congressman Jim McDermott, Mike and Gail Billington, and the over 600 business organizations which comprise USAEngage. Contrary to Senators Mitch McConnell and Diane Feinstein, they reject the 'hysteria in Washington' and in the American press, the ban on Myanmar's imports, freeze on assets, travel restrictions and financial sanctions. They underline the declining moral authority of the Bush administration in view of its human rights abuses in Iraq, Afghanistan and Guantanamo Bay and make the case for an economically and politically stable Myanmar contributing to regional and international security. In the words of Mike and Gail Billington (Economic International Review, 21 July 2004), it is the US, not Myanmar, which is isolating itself. Like John Badgley, David Steinberg and their colleagues (2004) they called for a rethink on US sanctions policy towards Myanmar. The organizations which comprise USAEngage go even further: they assert that US sanctions are harming the US economy itself, denying markets to its businesses, and undermining that very national security which the sanctions proponents in the US purport to protect (www.USAengage.org - accessed 25 June 2005).

Senator McConnell's impassioned speech (8 April 2004, www.senate.gov accessed 10 April 2004) threatening to have funding to the World Bank and the Asian Development Bank cut if they sought to re-engage with Myanmar, only serves to underline how little is known or understood about Myanmar on Capitol Hill. Rather than rhetorical declamations about 'freedom and democracy', as David Steinberg (2000) has argued, there needs to be a concerted effort to understand how Myanmar's political culture functions, how patron-client relationships work in pre-democratic polities, the nature of power and importance of status in such a traditional society. As Steinberg asserts (2000: 105), 'In societies where power is highly personalized and patron-client relationships are important, political parties play a secondary role to their leaders. Parties become the product and 
property of their leaders.' Instead of being a vehicle for democratic governance, they become a 'means to retain or seek authority rather than a unifying force in society' (ibid.). Western sanctions policies take no account of these traditional paradigms of power (ana) and influence ( $a w z a)$ in Myanmar political culture; they thus lose the opportunity to bring about the very political changes they supposedly wish to see enacted.

Proponents of the present policies often assert that Myanmar is 'isolated' by these sanctions. This is untrue. Most of the international community conducts normal international and trading relations with Myanmar; it is only the US and UK which give the appearance of being out of step. Following the renewal of US sanctions at the end of May 2004, the Myanmar Times, in derisive parody of the Bush rhetoric, labelled the sanctions 'weapons of mass destruction' for their negative impacts on Myanmar's social fabric. It called on the US to be 'more responsible and realistic in helping the people of the developing countries reach their common objective in becoming peaceful, stable and sustainable democracies' (Myanmar Times, 30 May 2004).

Similar views were expressed by noted economist, Professor Jeffrey Sachs, director of the Earth Institute at Columbia University and a special adviser to UN Secretary General Kofi Annan following a private visit to Myanmar in mid-2004. In an interview for the Radio Free Asia Burmese Service, 25 August 2004, posted on the Free Burma Coalition website (accessed 26 August 2004) he called for an end to sanctions, saying that they were making worse an already distressing situation. He stated,

Even the political opposition gets weakened - it doesn't have the income, talented Burmese people go abroad. In most cases, when you impose sanctions, it may weaken the regime, but it weakens the people and it weakens civil society. ... I don't think under any circumstances the international community should impose economic sanctions on such a poor country. Basically you know there is a terrible political crisis - it's an ongoing political stalemate - and I find it very distressing. But I also believe that impoverishing Burma through sanctions won't help the situation. I would like to see of course the political situation improve and I would like to see democracy come to the country. But I would also like to see hungry people in Burma have more food; I would like to see people who don't have jobs have the chance to have jobs; and I would like to see investment come to Burma... Sanctions hurt the people but they don't necessarily help the political situation at all.

Since neo-liberal institutional theory purports to maintain that economic development fosters an open society and democratic pluralism, it would seem that international sanctions are impeding the development of that very pluralism they are supposed to strengthen. Greater economic investment in the country would render significantly greater influence in seeking to bring about political changes. Ironically, the government of Myanmar is perhaps more aware of this than are 
US policy makers. At a time when energy security is a top priority for the US and its emerging competitors, China and India, the SPDC in early 2005 moved to ensure that exploitation of the country's onshore energy resources was reserved to state-owned enterprises.

In the wake of continuing US and UK sanctions, Myanmar has now adopted an international strategy which will enhance its political and economic security regardless of the policies pursued by the UK and US. Had there been wiser counsel behind these sanctions, the UK and US might have had more influence in the turn of events in Myanmar. Some slight awareness of this appears to be creeping into the UK consciousness at the parliamentary levels, despite the continued virulence of the Burma UK campaign. In a parliamentary debate in the House of Commons, June 2005, the speaker, Ian Pearson, Minister for Trade, was inclining to policies suggestive of a more modified UK position on Myanmar. ${ }^{7}$ As the balance of international power in the region changes over the next 5 years, with the continued rise and rise of China and India (and concomitant decline of Japan) there could be considerable regret that a more far-sighted policy was not pursued. ${ }^{8}$ Along similar lines, Beeson has raised the possibility of a shift in the fundamental relationships in the region in the wake of what he identifies as America's unilateral pursuit of 'its own narrow national interests' (Beeson 2003: 256).

\section{Conclusion}

From the above discussion it is clear that the moral, economic, political and strategic arguments behind the imposition and maintaining of Western sanctions have little real weight. Given that their ineffectiveness in bringing about regime change or evolution to democratic governance in Myanmar is patently clear, it is necessary to ask why they are continued. Explanations which heed the call of domestic constituents in the sender countries are also rather fragile arguments in terms of realpolitik. The answer lies more in the realm of strategic imperatives of the emerging international situation. For some years, there has been marked cooperation between Myanmar and Western countries on the issues of primary importance - sharing military intelligence, cooperating in the 'War on Terrorism,' cooperating on drug-suppression activities. It could be argued that this cooperation goes on out of the public theatre in which the flamingo-like dance of the sanctions is promulgated. Normal relations between Myanmar and its Western critics proceed behind the scenes, whilst the 'theatre' of rhetorical denunciations unfolds in public.

Given Myanmar's geopolitical situation, strong economic relations with neighbouring countries, China, India and Thailand, as well as Malaysia, South Korea and Japan, and strategic international linkages both in the Asian region and beyond, it seems highly unlikely that Washington strategists would be unaware of the inefficacy of the sanctions policies. On the contrary, it is patently clear that China's support for Myanmar ensures that the status quo will continue; China would also be highly unlikely to tolerate a Western-style and supported democratic regime on its back-door step. As discussed in Chapter 4, one of 
China's long-term strategic priorities is to ensure access across Myanmar to the Indian Ocean and become 'two-ocean operable' as have been all other great powers. For China, Myanmar is not just an economic investment but a key strategic investment. Washington would be aware of this. In discussions with a highly placed Chinese academic in mid-2005, I was assured that 'I do not think China will do anything [to bring about regime change in Myanmar]'. I agree: the last thing China would want on its back-door step would be a democratic Myanmar under a Western-influenced government. Myanmar's leaders would also be aware that their continued independence requires that they maintain excellent relations with China; this is their priority, not the US which is just too far away.

From another perspective, Myanmar does not have the scale of oil reserves which would be likely to make Washington consider the country essential to US energy security policy; hence Myanmar's strategic value, from the US perspective is small, not worth challenging China over that country's support for the Myanmar government. There is thus a strong possibility that the status quo suits both Beijing and Washington. However, because of its domestic constituency and the current directions of its foreign policy which, under Secretary of State Condoleeza Rice, claims to be based on ethical considerations of support for democracy and human rights, Washington strategists could never publicly admit that this is the case. A stable government in Myanmar - even a military one - suits both Beijing and Washington, although for different reasons. With the 'War on Terror' wallowing in the quagmire of Afghanistan and Iraq, an unstable government in a volatile region confronting Islamic fundamentalism, situated between the emerging economic and political giants, India and China, who will dominate international relations in the twenty-first century, is not to the taste of either Beijing or Washington. Summing up the strategic importance of a stable Myanmar for the region, Mohan Malik (2000: 275) observed that the country 'will remain an important factor in the regional security calculations of its neighbours in the early 21 st century'. Neighbours, unlike outsiders US and UK, need to work together for the greater security of all. In contrast to the West, ASEAN's anti-sanctions policy responds to the realistic imperatives of enhancing security in a volatile region.

There is no easy solution to the political impasse in Myanmar. However, encouraging tourism rather than promoting boycotts, encouraging cultural and scientific exchanges, fostering Myanmar's integration into the world economy and supporting its full participation in international organizations such as ASEAN and ASEM are likely to be more conducive to bringing about democratic change than are sanctions policies seeking to enforce isolation. Making Myanmar a player rather than a pariah (Malik 2000: 256) will bring its leadership within the circle of influence of international norms; excluding it will perpetuate its flouting of those norms. During the reform era of former Prime Minister Khin Nyunt, it is noteworthy that the country took public steps towards implementing some of these norms in the areas of laws prohibiting money laundering, human trafficking and recruitment of child soldiers. Those laws might not be perfectly enforced, but they are now on the books, which they were not previously. 
Myanmar is capable of moving, incrementally to adopt and enforce key international norms; its full participation in the international community will foster this development in its governance.

Power-sharing arrangements have been mooted in some quarters. Sachs for instance (interview for The Irrawaddy Magazine, October 2004) draws a parallel with Poland where staged power sharing laid a basis to move forward towards democratic governance and put the authoritarianism of the past behind it. ${ }^{9}$ How would such arrangements work in Myanmar given the SPDC's antipathy towards the civilian opposition and apparent intention to ignore international pressure for real dialogue with the NLD? If the now-stalled National Convention process were to resume, would the SPDC consider civilian leadership of some socio-economic portfolios, whilst, in an interim situation, the military retained control of those ministries such as defence, home affairs and foreign affairs, which it judged to be key national security concerns?

Pending resolution of these issues of high strategic moment, targeted humanitarian and developmental assistance to help rebuild Myanmar's socio-economic fabric, as Sachs suggests, cannot but benefit Myanmar's vulnerable populations in the long run. To the proponents of sanctions, it must be asked, how can assistance to help control malaria and HIV/AIDS, keep children from poor families in school, and ensure that women do not die in childbirth be unethical? Surely it is unethical to prevent such assistance being provided. Richard Falk (2004: 18-26), considering the international policy to use economic sanctions to foster improved human rights, concluded that they 'rarely' do so. On the contrary, he asserts, to 'create the sort of solidarity needed to promote dignity of persons throughout the world, it is crucial to address economic deprivations associated with poverty as human rights issues'. For wealthy Western nations to seek to deliberately promote poverty and deprivation in a small developing country, as Falk argues, is an 'obscenity'. Now that the West seems to have taken up the cause of poverty eradication in Africa (coincidentally timed to fit in with the IOC decision on the site for the 2012 Olympics), extending the same policy framework - humanitarian and developmental assistance, debt forgiveness and measures to encourage trade and investment - to poverty-stricken Myanmar might be more efficacious in bringing about the institutional development which sustains democratic pluralism and puts in place legal frameworks to protect human rights than continued symbolic sanctions. 


\title{
6 Civil society and the political ecology of sustainable development
}

\author{
Empowerment, opportunity and \\ participation
}

\section{Introduction}

It is no secret that the short-lived 'reform' programme perceived to be in train in Myanmar, 1997-2004, following its accession as a full member of ASEAN in July 1997, may now be compared to the 'Prague Spring'. And like that earlier experiment at throwing off the shackles of authoritarian governance, the Myanmar reform programme driven from the top by the former Prime Minister, General Khin Nyunt, and his faction of technocrat internationalizers, has come to a shuddering halt. The apparent promise of sustained political, economic and social reforms articulated in the Myanmar Agenda 21 document (NCEA 1997) has proven to be a mirage which held its shape only as long as General Khin Nyunt was in power, and disappeared once he was removed from office. That document had clearly been a blueprint, a code for the political transition processes by which Myanmar may have been able to transform itself from within and overcome its violent past (James 2003, 2004). Greater possibilities for empowerment of the peoples, more opportunities for enhanced 'capabilities' economic, social and political - through direct and meaningful participation in the governance of their country, have been aborted in the return to the indigenous patterns of governance characteristic of Myanmar's - and Western Europe's medieval/early modern period (twelfth-eighteenth centuries). If there is a lesson in this dismal episode, perhaps it is that a sustainable reform programme needs to be engendered from below gradually and slowly through building the institutional underpinning required to implement it. Reform programmes 'from the top' carry all the cultural patterns of pre-modern paternalism, if not outright autocracy, and are rarely sustained beyond the moment in power of their progenitors.

Such patterns of medieval governance locate actual, brute power in the hands of the strongest general/warrior king, regardless of lineage or perceived legitimacy. Thus the English King Henry IV of the House of Lancaster could depose and imprison his cousin, King Richard II, who was later murdered; Henry's grandson, King Henry VI, in turn fell to Edward IV of the House of York whose descendants were in turn eliminated by King Henry VIII during the subsequent Tudor era, in order to remove potential challengers whose very existence, he thought, posed a threat to the legitimacy of his rule. Similar patterns of strong-man/king rule 
prevailed in Myanmar from the Bagan era (ninth-thirteenth centuries), through the era of King Bayinnaung (1531-81) of the First Toungoo dynasty and throughout the last Konbaung dynasty (1752-1885). 'Legitimacy' always lay with the victor-warrior, with he who held the palace/capital, symbol of power (Lieberman 1984; Koenig 1990). Power resided with he who could manage the patron-client relations and networks of influence in a way which enhanced his own charisma. The late General Ne Win knew this and implemented it effectively, and ruthlessly, removing any potential challengers to his rule (e.g. Aung Gyi, Tin Oo) as swiftly as did the English King Henry VIII (Starkey 2004).

Legitimacy in medieval Western Europe and contemporary Myanmar resides with he who holds the 'palace', the capital city, symbol of actual power. It is not by chance that the SPDC leadership has moved to the new purpose-built 'capital' away from Yangon (the former seat of colonial power, 1885-1948) up-country to Pyinmana; removal to the new site will reinforce the symbolism of actual power, and re-enact the move to a new capital made numerous times in the past by legitimate Burmese monarchs (e.g. Thalun, Bodawpaya and Mindon). Legitimacy in the Burmese/Myanmar world view is not perceived to reside in elections, nor even in acknowledgment by the international community. Elections are considered merely a (foreign-originated) tool to a predetermined outcome, setting the seal of approval on foreordained policies driven from the top echelons of actual power. Such elections at local, regional and national levels were held frequently during the high tide of military dictatorship in Burma (1962-88) without changing or impacting on the overall pattern of authoritarian governance (Taylor 1987). National sovereignty, as spelled out to the UN General Assembly in 2005 by current Myanmar foreign minister, U Nyan Win, rather than Western notions of electorally driven legitimacy, is the primary motivating principle for the government in Myanmar. As Pedersen (2000) has suggested, trying to gain an understanding of the value systems and world view of Myanmar leaders, rather than seeking to impose contemporary Western notions of governance originating in different value systems, may assist in achieving better outcomes for the people of Myanmar as a whole.

Herein lies the basic divide between those activist groups living in exile in the West, who re-iterate that the SPDC is 'illegitimate' because it did not, and will not, acknowledge the results of the 1990 elections; and the government in Myanmar which locates legitimacy in the hands of he who holds actual power, and who controls the capital. It is noteworthy that even the Burmese Parliamentary Democracy Party (PDP), in exile, has recently stated that in its view the 'mandate' of the 1990 elections in Myanmar has expired (Free Burma Coalition website, 20 October 2005). The widely divergent views on what constitutes legitimacy between those who hold actual power in Myanmar and those who would deprive them of it, are at the base of the zero-sum game which has held Myanmar's future hostage since the assassination of General Aung San and six of his pre-independence cabinet on 19 July 1947, not by a foreigner, but by Burmese gunmen in the service of a rival Burmese politician (Kin Oung 1996). ${ }^{1}$ It is a tragic fact of Burmese history that those with the talents to steer the 
country to a better future have often been violently removed from public life. Whilst there is no doubt that the late General Ne Win on 2 March 1962 overthrew the government of the late Premier U Nu, whose 'Clean' faction of the Anti-Fascist Peoples Freedom League (AFPFL) had convincingly won the 1960 elections against the 'Stable' faction of his military-backed rival, Ba Nyein, it should also be noted that there was no international outcry at the time at Ne Win's military coup d'etat. In the era of containing the spread of communism in South-East Asia it was considered essential to restore order amidst the internal chaos into which U Nu's administration was dissolving. ${ }^{2}$

The details of the precise political, social and economic environment in which Ne Win's 1962 coup was launched are often obscured amidst the emotional reactions of those democracy activists who rightly decry the overthrowing of the democratically elected government, the last in independent Burma/Myanmar, and the ushering in of more than four decades of authoritarian, military governance. Similar resistance paradigms are applied to the results of the 1990 elections, in which the NLD won a majority of the constituencies, but was never passed the reigns of government. ${ }^{3}$ In recent communication on this topic, Derek Tonkin, former UK Ambassador to Thailand and Laos (1986-9) and Burma Desk Officer in the British Foreign Office (1963-6) commented,

On a technicality, no government can be overthrown until it has first been established, that is, until Parliament has met and the necessary procedures are completed for the appointment of a new government. In Burma in 1990, the National Assembly was never convened. It is not possible in logic to overthrow a government which has never existed.

There was in any case a fundamental difference of opinion between the military junta and the NLD in the run-up to the elections about what process should be followed to arrange the transfer of power, which Daw Aung San Suu Kyi herself fully recognised before she was placed under house arrest in July 1989 and which she said could take 'months and months, if not years' to resolve. So while I accept that the NLD acquired national and international legitimacy as the main elected representatives of the Burmese people, there was unfortunately no prior agreement or even tacit understanding between the military junta and the political parties about the mechanics for the transfer of power, and this was with hindsight a sure recipe for conflict. The blame lies overwhelmingly with the SLORC - it was their failure to communicate which led to chaos.

(Personal communication with Derek Tonkin, 26 September 2005)

It could in fact be queried, why the military government ever agreed to hold the 1990 election in the first place? Explanations resorting to an underestimation of the extent of the populace's desire for restoration of civilian rule seem to ring hollow, given the widespread pro-democracy demonstrations in the 1988-90 period, their violent suppression, and civil unrest which announcement on 
18 September 1988 (the day the SLORC took power in a military coup) of the forthcoming multiparty election (held 27 May 1990) and subsequent promulgation of the election law on 31 May 1989 did nothing to quell.

Under the above framework, articulated by Derek Tonkin, 1962 was the last time a democratically elected and constituted government was overthrown in Burma/Myanmar. Whilst the NLD unquestionably won the popular vote in 1990 (52.44 per cent of all votes cast), it has not enjoyed the opportunity to constitute a 'sworn in' cabinet in a functioning government. The government-in-exile, the National Coalition Government of the Union of Burma (NCGUB), from its various bases external to the country, similarly has not enjoyed the opportunity to constitute a cabinet in a functioning national government. Burma/Myanmar is yet to learn how to manage the peaceful transition of power. Alaungpaya, first king of the Konbaung dynasty, thought he had the answer when he allegedly decreed on his deathbed that each of his sons would succeed in turn (James 2000), but this led to internal fratricide, and ultimately a fatal weakening of the polity, predisposing it to colonial takeover in 1824. In the post-independence era, Ne Win made sure there were no obvious successors to his mantle, and various intelligence chiefs had their careers short-circuited. Only the last, General Khin Nyunt, survived more than 20 years, spanning the SLORC/SPDC era; as soon as he appeared a creditable threat to the current supreme commander, Senior General Than Shwe, he too was removed. Power in Myanmar remains personal, medieval, constituted only at the very top echelon, residing in networks of influence and factional deals, not dispersed throughout the populace who remain politically disempowered, economically disadvantaged and residing only on the margins of national life.

This is not a fascist, totalitarian state as Skidmore (2004) has sought to construct; nor is it a socialist worker's utopia or dystopia (depending on one's perspective); it is a pre-modern medieval polity wherein the resources, both human and natural, are at the personal disposal of whichever strongman happens to be at the centre of power. Those in power may kin muang as the Thai say, or 'eat up the country', as did the medieval barons in both monarchical Burma and medieval Europe, without the contemporary litmus test of 'corruption' being activated. ${ }^{4}$ Anti-corruption measures, when acted out in the public arena, in Myanmar are merely the theatrical props to a wider power play in the top echelons.

Myanmar lacks the institutional underpinning to move beyond this medieval framework. Skidmore (2004) may critique the social change which sees golf courses for the generals replace shanty towns on the edge of suburbia where the country's indigent formerly eked out a precarious living, but such a development is not unique to Myanmar and merely parallels similar land-use schemes which have occurred right around the region - in Malaysia, Thailand, Indonesia - since the 1960 s. In a country where all land belongs to the state (regardless of whether a democratic or military government is in control) under the Land Nationalization Act of $1953,{ }^{5}$ squatters in shanty towns, or elsewhere, have no secure property rights, and can be moved at will, as indeed were the inhabitants of the old royal capitals at Ava, Sagaing and Amarapura when the monarchs of the day decided that a new location would be more propitious for the dynasty. 
With no indigenous cultural predisposition to enhancing peoples' participation in the political life of the country (there is no equivalent, for example, of the Anglo-Saxon moot, the Petition of Rights or Bill of Rights) or culture of protecting human rights and enhancing human well-being, Myanmar's difficult passage from medieval to modern polity is compounded by the dire poverty which faces the more than 50 per cent of its 52 million people who live on less than one USD 1 per day (the World Bank designated poverty measure); by the severe strain on its health services caused by the increasing incidence of HIV/ AIDS, malaria, tuberculosis, unacceptably high infant- and maternal-mortality rate; increasing drug use and collateral socio-economic problems and resourcestarved educational system striving for parity with its South-East Asian neighbours (James 2003, 2004; Skidmore 2004). One of the poorest countries in the world, Myanmar substantiates the research of Land and Ersson (2000: 280-5) that human rights are best upheld and protected in economically advantaged societies; and, on the other hand, most abused in societies enmired in poverty. Affluence, that necessary ingredient to build institutional frameworks which protect human rights, enhance opportunity and empower the populace is restricted to a small elite at the apex of national power in Myanmar. This asymmetrical dispersal of the national resources and endemic poverty has been entrenched by the Western sanctions applied to Myanmar since 1988. Far from promoting the democratic transition in Myanmar, Western economic and financial sanctions are contributing to the abuse of human rights by subverting the institutional development which fosters an enhanced civil society.

Whilst democracy activist groups among Burmese/Myanmar exiles in the US, UK and Western Europe fondly plan their pressure campaigns on the assumption that Myanmar's medieval military governance is not sustainable, the cold hard facts of international politics continually proves them wrong. In a trenchant editorial in mid-August 2005, The Irrawaddy Magazine, funded by the National Endowment for Democracy in Washington, reversed its previous stance and called for a review by the international community of its long-standing policies on sanctions and isolation of Myanmar. The editor writes,

Sanctions may give moral support to detained icon Aung San Suu Kyi and the opposition, but there have been no indications the regime is about to fall.... There is no doubt that Washington's persistent criticism and sanctions are highly appreciated by dissidents and the opposition. But in Rangoon, many diplomats, UN agencies and other observers ... point out that the US policy of isolating Burma is rather counterproductive, because it means that by shutting the door to Burma, Washington cannot talk to the generals. This policy would be fine if the regime was [sic] about to collapse soon, but it isn't. More people are becoming critical of sanctions because they hurt ordinary people.... Sanctions cannot be really effective if neighbouring countries still engage Burma. Treating Burmese generals as pariahs may draw newspaper headlines and applause from dissidents, but it just makes the regime become more introverted, xenophobic, oppressive and isolationist. You are dealing 
with a mediaeval [sic] dictatorship, not sophisticated politicians. It is no secret that the U.S. has no strategy on Burma apart from sanctions. Its earnestness in trying to promote democracy and human rights in Burma is appreciated, but critics say it lacks vision, and its sanctions are ineffective. Therefore it may be time for all concerned to adopt a more results-oriented policy. A growing number of observers think it is time for a pro-active engagement policy in Burma, but with a timeframe and well-thought out strategy. This would require engaging both the regime and opposition, with inducements for change such as aid and stronger diplomatic links.... [M]en in uniform have ruled Burma for 43 years, and maybe it's time for friends and critics of the regime alike to review their Burma policy. There should be more down-to-earth consideration for the hardships of ordinary Burmese, and not just more lofty ideals of freedom and democracy.

(The Irrawaddy Magazine, 18 August 2005, accessed 20 August 2005)

Such an editorial represents a substantial change from the policy position espoused by The Irrawaddy Magazine previously. Given its strong links to the Washington funding agencies and political lobby groups on Capitol Hill, one can only surmise that this editorial is a vehicle to test the waters on a possible change in US policy towards Myanmar. But such a change would have to overcome the intense opposition of such high-profile political opponents as Senators Mitch McConnell and Dianne Feinstein. Will it be in vain that The Irrawaddy Magazine has called for a more 'results oriented' policy and an eschewing of the failed 'feel good' sanctions policies? Or will Burma/Myanmar just remain a 'world trouble spot' which 'few take seriously enough'? As Pedersen (2000: 225) has argued, the cooperative approach to international democracy promotion, rather than coercion, is likely to be more efficacious in modifying the authoritarian governance in Myanmar.

Burma... lacks groups with independent economic power that can act as a counterweight to the state and effectively push for an expansion of civil and political freedoms. By fostering economic development, international actors can facilitate the growth of such groups and thus pave the way for political liberalization and ultimately democratization.

There is little doubt that economic development in the long term could facilitate political change in Burma.

There is also broad agreement that both economic development and empowerment is best promoted by channeling as much aid as possible through NGOs working inside the country and in direct contact with the recipients.

(Pedersen 2000: 226, 236)

But therein lies the rub; domestic NGOs and INGOs now perceived to be too close to Western agencies have come under intense scrutiny in Yangon since the 
dismissal of General Khin Nyunt. The new leadership line up looks on some of them with suspicion that they may be serving the interests of external groups opposed to the government. International policies which support withholding economic investment and financial aid are thus now contributing directly to the entrenchment of authoritarian rule.

\section{Civil society and sustainable development}

These issues came to a head on 17 August 2005, with the decision by the Genevabased Global Fund to terminate its contributions to the programmes for control and prevention of HIV/AIDS in Myanmar. Some USD 37 million funding three programmes - HIV/AIDS, tuberculosis and malaria (cause of the highest number of annual deaths) - through its in-country partner, the UNDP, will be withdrawn over the next 2 years. With more than half-a-million people (about 2 per cent of adults) estimated by UNAIDS to be suffering from HIV/AIDS, Brian Williams, UNAIDS programme representative in Yangon, stated that at least USD 40 million would be needed for 2005-6 alone to provide anti-retroviral drugs to the 46,000 seriously ill patients. The lack of resources means that only 1,000 of these are presently able to receive the required medication. The US is the largest contributor to the Global Fund which is administered by the UN. When in July 2005, the government of Myanmar's new travel clearance procedures restricted access to project areas (usually in the north or north-east) by the UNDP, continued funding for these programmes was put at risk. Under pressure from US based domestic activist groups and their political supporters on Capitol Hill, the richest country in the world then chose to terminate its contribution to the Global Fund in respect of Myanmar, thus penalizing some of the poorest and most vulnerable people, in one of the world's most impoverished countries. Is this the action of a 'Civil Society'? Ironically, the US legislation enacting discontinuance of US contributions, the Department of State, Foreign Operations and Related Programs Appropriations Act 2006, draws the link between such funding and UNODC reporting on human rights abuses. The sections of the Act relevant to Myanmar state (H. R. 3057),

\section{BURMA}

SEC. 6031. (a) The Secretary of the Treasury shall instruct the United States executive director to each appropriate international financial institution in which the United States participates, to oppose and vote against the extension by such institution of any loan or financial or technical assistance or any other utilization of funds of the respective bank to and for Burma...

c) The President shall include amounts expended by the Global Fund to Fight AIDS, Tuberculosis and Malaria to the State Peace and Development Council in Burma, directly or through groups and organizations affiliated with the Global Fund, in making determinations regarding the amount to be withheld by the United States from its contribution to the Global Fund pursuant to section 202(d)(4)(A)(ii) of Public Law 108-25... 
(f) None of the funds appropriated by this Act may be made available for the United Nations Office on Drugs and Crime (UNODC) unless the Secretary of State determines and reports to the Committees on Appropriations that the UNODC in Burma is reporting to other relevant United Nations organizations incidents of gross human rights violations encountered during the conduct of its programs in Burma.

One would have thought that withholding assistance to HIV/AIDS sufferers could itself be constituted a 'gross human rights violation' unworthy of a country which constitutes to itself the role of protector of democracy.

Concurrently, in mid-2005 an increasingly negative stance by the Myanmar government towards international and national humanitarian assistance has become apparent, perhaps because it is an implicit criticism of government policy failures to enhance the well-being of the people. It thus calls into question the nature of that dearly cherished 'sovereignty' which the Myanmar Foreign Minister, U Nyan Win, defended to the United Nations General Assembly (UNGA). Sovereignty, after all, does not only reside in protecting artificially mandated borders; but also in 'the responsibility to protect' the people from the seven vectors of human insecurity (see Chapter 1) identified in the Human Development Report 1994 - economic, food, health, environment, personal, communal and political insecurity, all of which beset the people of Myanmar. This politicization of humanitarian assistance victimizes the most vulnerable. It beggars belief to think how those sponsoring this regrettable policy position - both in the US and in Myanmar - could possibly consider that democracy would be promoted, fostered or strengthened by penalizing HIV/AIDS, malaria and tuberculosis victims. Or that such suffering human beings would somehow rise up and overthrow the generals. But then reason and ethics have never inhered to international politics. ${ }^{6}$

There is no doubt that both foes and friends of Myanmar would like to see the polity move towards a 'more civil society' where accusations of egregious human rights abuses, child and forced labour, complicity in drug trafficking and exclusion of the majority of its citizens from participation in the political and economic life of this resource-rich country become archived in its violent past. Calls in September 2005 by former President of the Czech Republic, Vaclav Havel and former Nobel Peace Prize winner, Bishop Desmond Tutu, for UN Security Council intervention in Myanmar on the basis that the country is a threat to regional and world peace, are ill-founded, exaggerated, and reflect erroneous premises, despite the impeccable credentials of the report's sponsors. Nevertheless, such a report is a reflection of the frustration of the international community with its failure to achieve any substantial improvements in the governance of the country, whilst acknowledging the dismal humanitarian situation for many of its citizens. But despite the earnestness of the report's sponsors, Myanmar is not Rwanda, or Bosnia, or Darfur and intervention (military or otherwise) is not only not warranted but would also be unlikely to be acceded to by China, one of the five permanent members of the Security Council with veto power and a staunch supporter of the Myanmar government. In this regard, 
Myanmar's international relations policy in building solid alliances with China, as well as neighbouring India and ASEAN, will protect it from anything except the usual annual UN disapproval of its record in failing to make more substantial moves towards democratic reforms. Moreover, should the report actually reach UN Security Council (UNSC) for consideration, given their stance on the US-led war in Iraq, Russia and France, both permanent members of the UNSC would also be unlikely to accede to US sponsored military intervention in Myanmar; nor, one could suppose, given the embarrassment over Iraq, would the UK be eager to follow the US into another Iraq-style military adventure, with or without a UNSC resolution. Enmired in Iraq, it is difficult to see the US being eager to take on China, India-ASEAN, Russia and France, over Myanmar, no matter how low the esteem in which the current US administration holds the UN. The Jared Genser-Vaclav Havel-Desmond Tutu initiative is thus likely to remain Shakespearian theatrics, 'full of sound and fury, signifying nothing'.

Myanmar is currently in a 'holding pattern'. Its decision on 27 July 2005 at the ASEAN summit in Vientiane to forego its alphabetically determined turn to Chair ASEAN in 2006-7 was greeted with misplaced triumphalism by the US administration and activist groups around the world. Quite simply, Myanmar took this decision because it did not want the hordes of journalists and international visitors which assuming the Chair would have entailed. Chairing ASEAN in 2006-7 would have been rather inconvenient for the SPDC at this time. The decision reflected a win-win situation for all parties. This incident is another example of the parallel lines on which Western policy makers and the Myanmar government run: never meeting because of the widely divergent origins of the value systems conditioning their decisions. The decision should be seen more in terms of sloughing off an unwanted burden, than in the traditional 'loss of face' or even 'rubbing it in' interpretations hitherto applied to this incident. Again a lost opportunity for those groups in the West who allegedly wish to see democratic governance emerge in Myanmar. Had the country taken on the responsibility of Chair of ASEAN, the international community would have had significantly more opportunity to bring the leadership group in Yangon within the parameters of accepted international norms. As it is, the SPDC can simply steam ahead on its own recognizance with whatever policies it deems fit for the people of Myanmar. This tendency for international policy on Myanmar to run on parallel lines which never intersect is responsible for the lack of any impetus to transition to democratic governance in the country. When the National Convention drafting the new Constitution met in November 2005 it finalized a document which will perpetuate a major role for the military as keeper of the nation's security and sovereignty. A referendum will be held on this document; and only a Parsifal would consider that the subsequent results will be unfavourable for those in power. ${ }^{7}$ Such results of course will not be accepted by democracy activists; the cries of 'invalid' for a variety of reasons - no NLD participation; only the 1990 results are valid - will be loud. Such protests can be expected to be brushed aside by the government as the referendum produces the anticipated results. Many commentators will say that nothing has changed; but the country will at least have a Constitution on 
which a referendum will have been held. Of course, should the electorate take the opportunity to register its desire for real change, and for a 'sunset' clause on military domination of the national political agenda, by voting in the referendum not to accept the constitution, this might reopen the entire debate about the people's participation in the nation's political life.

The urgent need for a new international approach to Myanmar, in the interest of enhancing the well-being of future generations of its citizens, has been recognized and articulated eloquently by Dr Khin Zaw Win, a dental surgeon imprisoned for 11 years at Myitkyina in northern Myanmar for human rights work, ${ }^{8}$ and the group calling themselves 'Student Generations since 1988.' Applauding the INGO, the International Committee of the Red Cross (ICRC) which returned to Myanmar in 1999 (despite unexpected opposition to its doing so), for the real improvements to lives of political prisoners which it was able to bring about through its work in visiting the prisons and convict labour camps, Dr Khin Zaw Win comments,

The irony is inescapable: the economic decline during the previous one-party state in Myanmar and its attendant hardships had been one main impetus behind the upheaval of 1988. Now economic hardship is being prescribed to bring about democracy. For 26 years Myanmar experienced impoverishment in the name of socialism; it now appears there is to be impoverishment in the name of democracy.

(Khin Zaw Win, 'From a Frontline Trench', Free Burma Coalition, 30 September 2005)

His realistic analysis of how to bring about sustained improvements in Myanmar's governance does not look to the international community, or to the UNSC. He looks to the skills, determination, and savvy of the people of Myanmar themselves. In presenting a thumbnail sketch of options for moving forward he writes,

Myanmar is being subjected to economic warfare no less. In the assumptions and hopes of some, this would lead to political instability. And then what? In an atmosphere pervaded by coup and countercoup (actual and threatened), regional rebellion and outright hostilities, orderly democratic transitions, elections, constitutions and kindred things shall all come to naught. Even if those extreme situations were averted, a divided and ineffectual military set against a weak, faction-ridden and equally ineffective democratic government are still invitations to disaster. These are not nightmares that only happen to other people in other countries. They happened right in this country not so long ago. The spectre of the years immediately following independence still haunts living memories. Have the lessons not been learnt?

(Khin Zaw Win, 'From a Frontline Trench', Free Burma Coalition, 30 September 2005) 
Thus his suggestions for sustainable change reside in the realm of incremental improvements, the developmental curve traversed by Myanmar's prosperous neighbours, Thailand and Malaysia. The 'big bang' approach is to be eschewed; it is sensational, but not sustainable. In his view

What Myanmar needs is not just democracy, but stable and liberal democracy. This isn't merely a pious statement nor an academic one, nor a formula that people from well-meaning international organizations recite. It is an expression of painful necessity. The country's past experiences with democratization have not been altogether happy. After four decades of alienation there is now to be another, hopefully more sensible, attempt. It's going to include decentralization too. Call it multistage or phased democratization if you will, but it's certainly not a case of reverting to dictatorship.

If the real lessons of the setbacks and disappointments are taken and internalized, we can look forward to Myanmar's future democracy being on a much sounder footing. The Myanmar people should be enabled to make sober, unemotional and responsible choices regarding their own political future.

At this particular juncture there is really just a straight choice between two paths:

- Taking the most viable path there is and attempting to make it as liberal as possible; [or]

- Conversely, taking the most-touted liberal path and attempting to make it viable.

The international community could have a hand in either. Of one thing we should be clear though: attempting to keep the country poor and undeveloped is not the way to any kind of political solution, democratic or otherwise.

What can be seen in Myanmar is a society, a people, making the most of what they've got, exploiting every new opening, stretching their own safety nets, stepping into the unknown. Most of this is being done without any formal assistance or guidance, whether from the state or from overseas. It is a quiet but extensive and far-reaching exercise in self-help. If this country makes it through, it is little thanks to those in high places, at home and abroad. For any number of reasons, and in the long run, this really is the best way.

Dr Khin Zaw Win was released from prison in July 2005. His article circulated on the Internet in a number of Burma discussion groups. I have taken the trouble to quote from his testimonial at length because of the insight it provides into how Burmese/Myanmar see their civil society continuing to flourish at grass-roots level, to improve the livelihoods of people at the coalface, separate from both the state apparatus and the international community of aid-donor organizations. It is also testimony to the enduring Burmese/Myanmar belief in the efficacy of selfhelp. From a former political prisoner, imprisoned for seeking to improve human rights in Myanmar, it should receive some credibility from 'those in high places, 


\section{Civil society and the political ecology}

at home and abroad' whom he infers contribute little of practical worth to improving human well-being in Myanmar. One could be forgiven for thinking that present international policy on Myanmar, is, in the words of Ecclesiastes (6: 9) 'a chasing after the wind', a bastion for some personal careers, but not for the improvement of the well-being of the majority of Myanmar's people.

In similar vein, the Student Generations since 1988 which include the student activists, Min Ko Naing, Ko Ko Gyi, Htay Kywe, Min Zeya, and Zaw Min, on 6 September 2005 released a statement calling for greatly increased international humanitarian assistance to Myanmar particularly for the health and education sectors. I quote their statement below in full because it is diametrically opposed to the policies which recently led to the withdrawal of the Global Fund. Again, the credibility of this group of student activists has been tested in their own harsh experiences of authoritarian governance; yet they do not resile from the urgency and necessity of international humanitarian assistance to the country.

Statement by 'The Student Generations since 1988' on humanitarian assistance to Myanmar - 6 September 2005

1 We are 'The Student Generations since 1988', who are carrying out long-term national interests for Myanmar. We believe that effective measures are crucial as requirements for national health and national education in Myanmar are rapidly growing at present.

2 With the advancement of Information Technology, all the nations throughout the world today have to share the pros and cons in every aspect such as politics, economics, culture, health, crimes and terrorism. No nation can cope with this situation on its own.

3 We firmly believe that it will be more effective, especially for a least developed country like Myanmar, to receive humanitarian assistance through cooperation with the international community in handling health and education crises.

4 It is necessary to provide humanitarian assistance in accord with the internationally recognized standards so that the assistance will reach those who really need it. The mechanism for that assistance should be unbiased and transparent, and be completely available for inspection. We believe that it is the responsibility of the recipient country to create such mechanism.

5 At present, remote border regions of ethnic minorities in Myanmar are suffering from more serious crises in education and health sectors. Therefore, cooperation with the international community is essential in tackling the national crises such as the education and health ones.

6 In order to cooperate with the international community, it is crucial for establishing an appropriate mechanism through coordination, cooperation and joint implementation between the military government and all democratic forces.

7 We, 'the Student Generations Since 1988', will fulfil with all our might the national requirements. We would like to call for cooperation and 
coordination among the military government, the UN agencies, donor countries, the international community, local non-governmental organizations and independent associations for social services in order to fulfil the humanitarian needs of Myanmar people together with us.

(The Student Generations since 1988,

6 September 2005)

Such appeals from these incontrovertibly credible sources should awaken Senators McConnell and Feinstein, and the lobbyists behind them, to the fallacies in the policies they have been pursuing. It is tragic that their moral vision precludes assistance to the very sectors in Myanmar which could, in the long run, sustain the type of pluralistic democratic governance they allegedly wish to see evolve.

Like Dr Khin Zaw Win, the Student Generations since 1988 highlight the existence and work of local non-government organizations and independent associations for social services in tending to the humanitarian needs of the population. It is not correct to consider that there is no civil society in Myanmar: civil society organizations are burgeoning. From over 50 such organizations a few years ago (James 2005), the numbers have mushroomed. Myanmar seems to exemplify Julie Fisher's (2003) thesis that civil society gradually increases social and political space through the operations of both horizontal and vertical networks in proportion to the repressive apparatus of the authoritarian state in which it is encapsulated. This is particularly so in response to need; where other help is not available, self-help becomes mandatory, and Myanmar people have a long indigenous tradition of self-help, through small, local organizations, religious and professional associations, social groups (e.g. 'book clubs' such as the Nagani Book Club which fostered early political opponents of colonial rule) and ethnically based associations such as the Metta Development Foundation in Kachin state. The religious sector in Myanmar has long been active in fostering social and political change, both in pre- and post-independence Burma/Myanmar. On 28 September 2005, Toe Zaw Latt, a Burmese exile living in Thailand, who is intensely critical of Prime Minister Thaksin Shinawatra's policy on Myanmar, wrote in the Bangkok Post, identifying two senior Buddhist leaders in Myanmar as having 'appealed to both sides to be flexible and to end the suffering of the Burmese people. They are Sayadaw U Zawtipala, abbot of Kyakhatwaing Monastery in Pegu, and Ashin Kundalabiwuntha of Mahaghandharon Monastery in Mandalay'?

As Kyaw Yin Hlaing has demonstrated, the military government, contrary to most academic opinion, 'was never able to wipe out civil society organizations' even during the Ne Win socialist era. A large number of what he calls social movement organizations or SMOs then re-emerged after 1988.

Most of the SMOs that led the Four Eights democratic movement were not the organizations that emerged after the breakdown of the socialist movement but the groups, formal and informal, that survived the military's cleansing 
campaign. Most Burma-watchers failed to acknowledge the existence of civil society organizations because they thought that only formal organizations could function within the limits set by the government. In their opinion, civil society could not exist if there was no legitimate official space for civil society organizations.

(Kyaw Yin Hlaing 2004a: 389-90)

His research supports Fisher's (2003) thesis above. The more repressive the governance, the more the people felt that 'the state did not have the exclusive right to establish the parameters of civil society. In politically unfavourable circumstances, activists formed informal organizations' (Kyaw Yin Hlaing 2004a: 389-90). Informal social groups then should, he believes, be included in civil society because they function in a manner similar to their counterparts in democratic countries. Where activists sought to turn these informal groups into politically conscious SMOs, they could function in counterpoint to those legally sponsored state groups established to strengthen social control, for example, the Myanmar Women's Affairs Organization and the Union of Myanmar Chamber of Commerce and Industry, which, while established to generate greater public support for government policies, 'engage mainly in apolitical activities' (Kyaw Yin Hlaing 2004a: 406). Kyaw Yin Hlaing sees these latter groups as being capable only of bringing about gradual political change. He, however, accords local religious, social and, in some cases, business organizations, (e.g. the independent Mandalay Traders, Brokers and Industrialists Association) and informal networks the capacity to make significant contributions to enhancing social and political space and even to become fully fledged social movements. ${ }^{10}$

Through such essentially self-help structures greater opportunity to participate in the economic and social life of the country is being created, by the Myanmar people themselves. Despite severe limitations on political empowerment, the people of Myanmar do not inhabit the Kafka-esque world portrayed by Skidmore (2004); as indicated by Dr Khin Zaw Win, utilizing their own limited resources, and in the face of an inhospitable international environment, with grace and dignity the people of Myanmar are gradually increasing their civil society space, putting in place measures to alleviate poverty, foster peace amongst the conflicting ethnic groups and deal with the scourges of HIV/AIDS, malaria and tuberculosis. They are developing their own civil society consistent with their own cultural mores and domestic resources, in their own time-honoured 'self-help' fashion. In doing so they demonstrate greater efficacy and resilience than those Western-based activists whose cyber-warfare and sophisticated lobbying produced the ill-conceived and misnamed Burma Freedom and Democracy Act 2003. As Donald M. Seekins (2005: 452) has written, 'the Burma Freedom and Democracy Act is a half-measure that does more harm than good. It reflects fundamental ignorance of Burmese society... The U.S. government, working in cooperation with other countries, including those whose Burma policies differ from Washington's, should support policies that help, not hurt, the people of Burma.' However, even if an unprecedented about-face occurred in 
Washington - unlikely, given the entrenched positions espoused by influential politicians on Capitol Hill - Western influence in Myanmar is now so small, so ineffectual, that, in archetypal fashion, envoys bearing gifts would be likely to receive short shrift. Myanmar's most influential friends are those on its nearest borders. An increasingly vibrant civil society in Myanmar and sustainable political and social change will henceforth be more closely contingent on the political, economic and social policies which proceed from interactions with China, India and Thailand.

Contrary to the notion that the concept of Civil Society is inherently tied to its Western origins in European social and political thought, the volumes of Alagappa (2004), Hann and Dunn (1996) and Schak and Hudson (2003) demonstrate conclusively the integral role of civil society organizations in Asia in fostering social and political change, their long history (sometimes pre-colonial) and increasing presence and varied charters. These authors also demonstrate that civil society in Asia does not always operate according to the corporate Western model, in opposition to the state, nor is it entirely co-opted in the service of the state; constantly evolving, civil society in Asia works across both horizontal and vertical networks, both in cooperation with, and in contrast to, the state apparatus. Moreover, civil society in Burma/Myanmar, like in Sri Lanka and The Philippines, in Alagappa's view, evinces the neo-Gramscian, rather than the neoTocquevillean, mode wherein counter-narratives are constructed to undermine the hegemonic narrative of the state. Distinguishing what he calls, the two 'frames', Alagappa comments,

If the state and the accompanying socio-political order have a high degree of legitimacy and the state has a high capacity for governance, then the neoTocquevillean frame is dominant. If there is widespread lack of agreement or certain minority groups vehemently oppose the configuration and identity of the state and its political system, then civil society organizations (along with those in political society) are deeply divided espousing totalizing goals that make for bitter contests. In these situations, civil society becomes the terrain for struggle and dominance. The neo-Gramscian frame dominates in these countries. The features and strengths of civil society hinge on the progress made in construction of legitimate national states, political institutions and processes.... Civil Society organizations are not passive; they are active players in the state- and nation-building (or destruction) processes and in the construction of the system of governance.

(Alagappa 2004: 468-9)

Consistent with the views of Cohen and Arato (1992) that civil society is broadly the realm of social and political interactions between the state and the individual, Alagappa correctly asserts that civil society in Asia should be treated as an arena of governance in its own right, and not a mere tool to influence the state, political society or the market (Alagappa 2004: 32). He considers civil society simultaneously a 'space, a site, and an actor' (ibid. 33) which is 'a realm of power, inequality, struggle, and conflict among competing interests' and which demonstrates 
that it is 'self-organized, self-governing, non-state, non-profit, non-private institutions that employ non-violent means to achieve a public interest or good through collective action' (ibid. 34). Asserting that the 'balance should favor the individual's freedom to associate,' Alagappa identifies the key characteristics which make civil society 'civil'; they are the 'absence of violence and will to dominate the entire public realm' while 'Groups that avowedly resort to violence to achieve political goals, like the various liberation movements, cannot be part of civil society' (Alagappa 2004: 35). His definition nicely distinguishes between the Sri Lankan Tamil Tigers, the All Burma Students Democratic Front (ABSDF) in Burma/Myanmar, ${ }^{11}$ the CPB, Kachin Independence Organization (KIO) and Karen National Union (KNU), Lanzin Youth, and Union Solidarity Development Association (USDA) on the one hand; and the Shalom Foundation, the Metta Development Foundation, the Mandalay Traders, Brokers and Industrialists Association, the Byamaso A-thin (Kyaw Yin Hlaing 2004a: 407) and the informal professional, religious, community, social and study groups whose primary aims are non-political and non-violent.

Alagappa, however, has too narrow a view of what is happening in Myanmar. Whilst it is true that legal space for politically motivated groups aiming to overthrow the state is severely restricted and their memberships are oppressed and routinely jailed (as in other neighbouring South-East Asian countries), it is going too far to assert that: 'Burma allows almost no legal space for even quasi-autonomous civil society organizations. Confrontation is the only mode of interaction between unofficial civil society and the state' (Alagappa 2004: 500). In fact the most effective civil society organizations in Burma/Myanmar do not operate in 'confrontation' with the state; working within the permitted parameters, admittedly more restricted than might be enjoyed by their counterparts in some Western countries, they are gradually carving out social space and expanding their horizontal and vertical networks through measures to improve the well-being of Myanmar's vulnerable populations. Alagappa's statement that, owing to 'suppression... some organizations altered their formal roles; some operated informally or went underground; some relocated to border areas where the government's reach was limited or contested; some moved to neighbouring Thailand or formed associations in the U.S. and the European Union' (Alagappa 2004: 497) applies only to those politically driven organizations, often espousing violent means to achieve their ends, which in fact do not meet his own criteria for what constitutes a civil, Civil Society. It also devalues, and minimalizes the alternate, non-violent means of achieving peaceful evolutionary social and political development from within the society by its own resources. An evaluation of the efficacy of the non-state, not-for-profit, voluntary sector in Myanmar needs to be made within the envelopes proposed by Hann and Dunn (1996), and Schak and Hudson (2003) mentioned earlier; that is, by looking at how civil society in Asia, still using Alagappa's valuable characterizations above, moves within norms consistent with its communal, cooperative cultural outlook to achieve better outcomes for the individual which would not be inconsistent with the standard neo-Tocquevillean frame of its Western-based cousins. 


\section{Human security and civil society}

Civil society, consistent with Alagappa's definition, is often seen as the lynchpin in fostering greater human security and sustainable socio-economic and political development. International aid organizations commit resources to its strengthening, viewing it as an alternative to the state where authoritarian governance has put vulnerable populations at risk or failed to deliver the services and policies necessary to avoid human insecurity. In such circumstances, civil society becomes the key vehicle for achieving greater human security and for alleviating the impact of policies which have increased human insecurity.

But civil society can also be uncivil in its own governance; to be effective, it needs interaction with the state in developing and implementing the policies at the core of its own justification for existence (Tendler 1997). Use of both vertical and horizontal networks is essential for civil society to influence government policy making and to implement service-delivery programmes. It cannot 'bowl alone' (Putnam 2000) without reducing its own social capital. Civil society is no easy panacea for political and social 'ill-being'. And, as Alagappa (2004) has shown, civil society cannot deliver viable national-level democratic governance solely under its own steam. In Thailand, for instance, in the 1974-5 period, civil society fragmented and dissolved into competing groups which wreaked violence on each other, a far cry from its civil objectives; then in 1976, some of the civil society groups including sections of the media assisted the Thai military in retaking control of the nation's political life. Similarly in Myanmar, neither state nor civil society on their own can deliver greater well-being to the people. Whilst many of the non-political civil society groups working in the health and health education sectors which would meet Alagappa's definition cited earlier, go on doing excellent work under difficult circumstances to alleviate the suffering of the vulnerable (especially HIV/AIDS patients) other groups with overt political objectives, such as the ABSDF, the KNU, the USDA, as Kyaw Yin Hlaing (2004a) has shown, have not been able to resist the attraction of violence in achieving their ends. Such groups, however, would not meet the 'non-violent' criterion in Alagappa's definition. They would, in effect, not be civil. Following this line of reasoning, we would conclude that groups resorting to violence would exclude themselves from the human security framework, since their actions would only serve to embed the already great propensity to human insecurity.

On 7 May 2005, Rangoon was rocked by a series of bomb explosions at several centres: at two supermarkets crowded with people shopping and at the convention centre in west Yangon where a Thai trade fair was being held, resulting in several deaths and many injuries. An eyewitness (The Irrawaddy Magazine, 13 May 2005) reported, 'It was the most sickening thing I have ever seen - dead, wounded and blood-covered monks, women, children piled up on stretchers and on the floor of a third-world hospital.' Earlier in the year a bomb in Mandalay market had killed two women and wounded 15 others. Such attacks on civilians were unprecedented in Myanmar's recent history. They had obviously been carefully planned to penetrate the tight security enveloping the city and were aimed at 
civilians rather than the military leadership. Initial attempts to seek the perpetrators amongst the regime's long-time, known political enemies - the KNU, Shan State Army, Karenni National Progressive Party and the NCGUB - were discounted as not credible. Internal origins amongst the displaced Military Intelligence group were similarly discounted (as most of these operatives were in jail), as were possible originators amongst the ceasefire groups, the opposition NLD, and the government itself. Aung Zaw, The Irrawaddy Magazine, 13 May 2005, advanced the theory that 'a new radical group has arisen, with no ties to mainstream movements' which draws support from sources external to Myanmar. However, the question still arises, how such a group could penetrate the capital's tight security; dissidents in exile in turn pointed to internal sources amongst government ranks and the armed forces as the only groups with both access to the requisite skills, bomb-making expertise and opportunity to plant the devices. To date, no solution to questions of who or why has been achieved. Rival power groups in Yangon would not normally target civilians. The notion that the bombs were intended as a "message to the regime' also seems rather opaque. What message, one might ask? Could there have been commercial rivalry at the bottom of these incidents? But this again begs the question of opportunity and capacity. Whatever the origin of the perpetrators and their objectives, it is clear that the bombings shook the top leadership group. Yangon and Myanmar had hitherto been conceived as free from the type of urban terrorism plaguing Iraq. The lack of satisfactory answers served to increase the state-security framework and decrease the opportunity for civil society. The pendulum allocating responsibility for human security was inexorably swinging back towards the state apparatus, a trajectory likely to be accelerated by the latest bomb blast on 21 October 2005, outside the popular Traders' Hotel, in downtown Yangon (Democratic Voice of Burma, 22 October 2005). In this incident, no casualties were sustained.

In this context of a recognizably fragile environment for human security in Myanmar, the Vaclav Havel-Desmond Tutu report was commissioned urging UNSC intervention in Myanmar. Released on 20 September 2005, the report, entitled, 'Threat to the Peace: A Call for the UN Security Council to Act in Burma' was prepared by DLA Piper Rudnick Gray Cary, a global law firm with over 2,900 lawyers in 53 offices and 20 countries around the world. It has already aroused heated debate between those responsible for its authorship and those who respectfully point out its many inaccuracies, unfortunate timing and strategic imprudence. Highlighting the inaccuracies which detract from its impact, Derek Tonkin (Burmese Perspectives, Guildford, UK, 4 October 2005), a former senior UK diplomat and long-time Burma watcher, suggested that if 'specialist legal advice' was sought 'in the framing of this outline Resolution, they [i.e. the report's sponsors] should certainly ask for their money back'. The statement released by the Myanmar Ministry of Foreign Affairs, 29 September 2005, predictably goes further. Summarizing the government's achievements in moving the country towards peace and stability and greater protection of human rights, the statement asserts

The report contends that the government poses a threat to its own people and to regional peace and security and strongly urges the UN Security Council to take up the situation immediately... 
The Ministry of Foreign Affairs is of the view that the report is yet another attempt to discredit the government of Myanmar. It is based on misinformation by a few remaining insurgents and foreign funded expatriates who are now fearful that they will soon be irrelevant when Myanmar crosses the threshold to a new era. They are after all expatriates who are funded by some western countries with a hidden political agenda.

The government is striving to overcome the challenges faced by the nation relying mainly on its own resources. It welcomes the understanding and support of the international community. However, reports as the above, are counterproductive and not of assistance in the efforts of Myanmar towards democratization. The Ministry of Foreign Affairs therefore rejects the report in its entirety.

Whilst opponents will discount the government's assertions of its achievements, the report's claims that Myanmar is a threat to regional peace, asserting that the HIV/AIDS strain originated in Myanmar and followed the drug routes out to other parts of South-East Asia, are nonsense. Commenting firstly on this issue of HIV/AIDS in Myanmar, Jean-Luc Lemahieu, Chair Joint Program on HIV/AIDS and Representative of the UN Office on Drugs and Crime (UNODC) in Myanmar, personally advised Jared Genser, the compilers' spokesperson for the report, on 28 September 2005

Considering the highly-respected integrity of those who committed the report, it is therefore regrettable that various inaccuracies appeared in the text with the potential to take away some of the relevance of the arguments you submitted. Kindly allow me to illustrate this for those areas falling under my technical mandate as UNODC representative and Chair of the UN Joint Program on HIV/AIDS.

The suggestion (no conclusive evidence) that HIV/AIDS originated in Myanmar, was first made in a recent report titled 'HIV and Security: Where are the links?' Exactly in order to avoid any misunderstandings, the UN made an ensuing statement that different strains of HIV have been identified in Myanmar, suggesting the meeting of various networks of HIV transmission. There is no definitive evidence on the origin of the strain, or on the direction of their spread. While published on many internet sites, I am afraid that this important feature has been overlooked in your report.

Moreover, Jean-Luc Lemahieu supports the government's assertions of the efforts being made to eradicate drugs and to stem the production and outflow of metamphetamines. He writes, and I quote at length because of the importance of his testimony and the balanced perspective he gives to these emotive issues,

What concerns the chapter on the drug issue, the factual description recycles a number of arguments about the drug situation in Myanmar that have been and continue to be used in political, not technical, forums. Few will argue that the drug control situation in Myanmar has reached the optimal levels the 
international community would like to see achieved. Especially what concerns the synthetic drugs added efforts are required. Yet and perhaps regretfully for those who want to argue the contrary, but in line with serving objectivity, significant progress has been made over the most recent years and many of the allegations contained in the report have proven inaccurate from a technical perspective.

For instance, you state that the opium decline is a result not of government policies, but of 'other factors such as changing weather and soil conditions' (p. 26). Allow me to explain that total opium production is a function of two factors: the area under cultivation, and the yield. In the case of Myanmar, the yield fluctuates significantly year on year, primarily because of the weather. For this reason, when evaluating the effectiveness of policies in reducing opium cultivation and the political will to implement such policies, the area under cultivation is a better indicator. In Myanmar, the area under opium cultivation declined by $79 \%$ between 1996 and 2005 .

Yet, turn it around, when accounting for opium production instead of opium acreage 'the former being an aggregate of acreage and yields and thereby allowing the inclusion of weather conditions' the decline in the same period is $81 \%$. This does not suite [sic] well the statement 'Although the regime claims to have undertaken substantial steps to reduce opium production in recent years, these efforts have failed to produce any substantial decrease in drug production' (p. 26). In case the UN figures are in doubt, kindly refer to the published figures of the US Government which confirm our trends-analysis although, in nominal terms, the US data are even more optimistic than ours.... You correctly refer (p. 26, footnote 313) to an interview in which I stated that drug burning ceremonies have essentially a public relations function. It seems rather obvious to me that, as with any other ceremonial undertaking, the substance behind these official declarations should remain decisive. This is the rationale why the UN engages in its annual comprehensive opium surveys. I trust that the conclusive data gathered during these exercises speak for themselves. Not for nothing the article in which I was interviewed was titled 'Making Inroads' (The Irrawaddy Magazine, Vol. 11, No. 4, 17 May 2003).

The extent of and reasons for the decline of opium cultivation in Myanmar are often used to serve a political score. Very regretfully, one critical point is rarely touched in these discourses - that opium reductions in Myanmar are affecting the livelihoods of an estimated 2 million already very vulnerable and economically deprived people (UNODC, 2003 Opium Survey).

For the UN as an entity, replacing one social evil with another must not be considered a victory. For this reason, the international community, regional and local partners are combining forces in order to provide for the basic human needs of those affected, meanwhile extending protective shields against human trafficking, human right abuses, forced relocations, chronic food deficiencies, malnutrition, reduced school enrolment, and poverty, to name a few. I assume that we easily can agree that objectivity benefits a 
mature discussion and opens better perspectives towards a broad coalition providing sustainable solutions for those who are today most in need. We will also agree on the notion that humanitarian assistance should bridge the political divide, not widen it.

I will close off by referring to a statement made by Mr. Costa, Executive Director of UNODC, during the launch of the 2004 opium survey publication. 'The world has watched as various countries have struggled to eliminate the cultivation of opium. Some states have succeeded others have failed. In Myanmar there remains a fine line between sustained success and failure. The UN continues to believe that the international community, the region, the country itself and its people have a shared interest related [sic] to drug control. Translating this convergence in joint action will finally determine the success or failure of the drug efforts in Myanmar.

(Jean-Luc Lemahieu, quoted on Free Burma

Coalition website, www.freeburmacoalition.org,

28 September 2005)

To try to construct a threat to the peace out of such material is clutching at the proverbial straws and denigrates the otherwise worthy aims - improving human security and human rights - of the report. Derek Tonkin notes that the overreach of such claims not only undermines the reports credibility, but also reduces the chances of any substantial UNSC action and in fact becomes counterproductive. ${ }^{12}$ This long time Burma watcher summarizes the situation as follows:

The Havel-Tutu report makes the valid case that there are transnational issues which are of serious regional concern, such as the spread of HIV/AIDS, the trafficking of narcotics and the flow of refugees into Thailand and India. However, in characterising these and other issues as 'a threat to peace' meriting action under Chapter VII of the UN Charter, the Havel-Tutu report fails to mention that not a single country in the region affected by these transnational issues has characterised them in this sense. Without their support it is difficult to see how the US and her partners thousands of miles away from the scene of action can secure general agreement in the Security Council that a Chapter VII situation exists. I doubt they would even try.

As recently as June this year China and Russia, two Permanent Members of the Security Council with veto rights, declined to accept Burma/Myanmar as an agenda item for a Security Council meeting. More recently, US State Department Assistant Deputy Secretary Eric John told a House SubCommittee on 21 September that the US was working with their partners to place Burma/Myanmar on this month's (October) Security Council agenda. I believe that they and their partners, including the UK, would be more than pleased to secure Chinese and Russian acquiescence to a discussion, even if only informal and unrecorded. The recommendation however for a Security Council Resolution under Chapter VII which should be, as the report also recommends, 'consistent with its powers under Article 41 of the 
Charter' (Page 65 of the report - the powers relate to measures to be taken, particularly sanctions in the event of non-compliance) is likely to strike UN delegations, and particularly Members of the Security Council, as well outside the realms of what is politically possible, however much they may agree with the broad sentiments expressed in the outline Resolution....

There are times when an overstated and too dogmatic an approach in pursuit of a worthy objective can be counterproductive. Already the HavelTutu report has unfortunately aroused unrealistic expectations, particularly among ethnic groups fighting for autonomy in Burma/Myanmar, that the Security Council is poised for action in which China and Russia are likely to acquiesce. This is very unlikely to happen. A possible result of such deception could be to polarise further East-West differences over how best to handle the situation in Burma/Myanmar, to cause unnecessary psychological depression and to set back the transition to civilian rule by consent in Burma/Myanmar.

(Derek Tonkin, Free Burma Coalition website at www.freeburmacoalition.org, 28 September 2005)

On the other hand, the NLD, the Committee Representing the People's Parliament, the Democratic Voice of Burma (DVB), and the Student Generations since 1988 warmly welcomed the report, stating that it correctly presents the situation in Burma/Myanmar, and commented on its 'goodwill' and 'sincere motives'. Perhaps the NLD's comments may be taken as representative.

The National League for Democracy is therefore grateful to the former Czech president and the Archbishop for the detailed and accurate report they have submitted. We believe that the report has been prepared out of genuine and sincere motives.

Moreover, in their report, these two outstanding and respected world figures have not in anyway cast a slur or blemish on any organization or country. The report focuses on Burma' s problems and its needs and the way to solve them. For these reasons we are convinced that this is the outcome of genuine goodwill.

When this subject is brought before the Security Council we urge and solicit all members to unite and cooperate and work together for a successful outcome and to refrain from exercising their veto powers.

(NLD 21 September 2005; posted on Free Burma Coalition website at www.freeburmacoalition.org, 28 September 2005)

No detailed assessment of the report, however, has been provided by any of the opposition groups. This may be expected as their objectives are to support the philosophy of the report rather than its substance. It seems that in terms of the harsh realities of international politics, the report will be one more stage prop in the theatrical drama that is contemporary Myanmar. Closer to political reality are the views of Professor Paulo Sérgio Pinheiro, UN Special Rapporteur of the Commission on Human Rights, on BBC 'Hardtalk' 1 September 2005 - 'China, 
India and Thailand... I think that they have the key to change in Myanmar, I think that in their own way, in their own style they have some qualities to convince the Myanmar authorities that, for instance, the road map cannot be stuck and waiting for ever... 'His recognition of the importance of Myanmar's closest neighbours, their own styles of communications, their own modes of diplomatic address, should be treated with great respect by the international community. Since their own national interests and national security are closely impacted on by what happens in Myanmar, in very real ways, more so than that of far-away Western countries, their role in achieving peaceful change in Myanmar should be accorded greater prominence in the security discourse. As Derek Tonkin has noted, 'the importance of these three countries in assisting the process of democratization, security and stability in Burma/Myanmar may offer a more practical way forward for the Security Council to consider than Chapter VII action' (Derek Tonkin, Free Burma Coalition website at www.freeburmacolition.org, 28 September 2005).

Since the publication of the NBR report, Reconciling Burma/Myanmar: Essays on U.S. relations with Burma, in March 2004, 'rethinking Burma policy' has become somewhat of a small industry. Not only did The Irrawaddy Magazine publish a substantial editorial in August 2005 on the subject (referred to earlier) but also, a little earlier in the year, the redoubtable magazine, The Economist, in July 2005, also began preparing the ground for some move in the West's no-surrender policies on Myanmar. It proclaimed, 'Ostracizing Myanmar has not helped its people. It is time to explore the possibility of a deal.' Noting that 'Even Miss Suu Kyi herself has already conceded that an absolutist approach is not practical,' The Economist proposes a phasing out of sanctions in parallel with agreed changes in Myanmar, including the release of Daw Suu Kyi from detention. It argues

The world needs to recognize that there is little hope of influencing the regime unless a more coherent policy can be found, even if that has to mean easing up on the generals in some limited respects. As a start, Europe and America should at least co-operate with one another. They might also try harder to persuade their allies in Asia that a better-run Myanmar is in everyone's interests. The United Nations should also play a more active part... Diehard opponents of the regime will complain that any concessions simply reward the generals for their intransigence, and give them an incentive to haggle over every step down the road to reform. But the alternative, an insistence on the regime's unconditional surrender, has got them precisely nowhere over the past 15 years... And there is no doubt that ordinary Burmese have an interest in improving the government's disastrous economic management, checking the alarming spread of AIDS and putting an end to Myanmar's endless guerrilla wars, in addition to political reforms ... Maybe a step by step plan, implying a degree of cautious engagement in return for real reform can do better.

(The Economist, 21 July 2005, on Free Burma Coalition website, at www.freeburmacoalition.org, 22 July 2005) 


\section{Civil society and the political ecology}

The day before, on 20 July 2005, the US Senate had voted overwhelmingly, by a vote of 97 to one, to renew the ban on the import of Burmese products to the US, a symbolic act since Myanmar has long since replaced this lost market with others closer at hand in India, China and Thailand. It is not only the generals in Yangon or in Pyinmana where the centre of government is now located who are intransigent.

\section{Conclusion}

In the present impasse, enduring political change in Myanmar seems very distant. The deck chairs on the Titanic may eventually be moved as prophesied by Larry Jagan in the Bangkok Post, 12 October 2005, but a sustainable political system which returns sovereignty to the people through 'free and fair' multiparty elections is not likely to evolve from the processes which will be set in train after the conclusion of the National Convention reconvened in December 2005, it met until 31 January 2006. Whether the Senior General Than Shwe becomes a 'civilian' president for life; whether Vice Senior General Maung Aye is edged out to make way for General Thura Swe Mann; whether another generation of generals replaces the present leadership group will all make little contribution to either enhancing the well-being of Myanmar's people or moving the country towards genuine democratic governance. Myanmar's institutional underpinnings to support democratic governance are so fragile that any real change from its present authoritarian governance will need to be incremental. The value systems and legal frameworks from which norms are derived and which inculcate a political culture able to uphold human rights need to be developed from first principles. In the current hostile international policy towards Myanmar, no such change in value systems, legal or institutional frameworks is possible, as the country prioritizes state and national security ahead of human security. To enable Myanmar to undertake sustainable reform from within, the only approach which will enable the processes to become embedded and indigenized through their ownership, the current international policy towards Myanmar needs to be totally stood on its head. 


\section{Conclusion \\ Towards a more civil society?}

\section{Introduction}

In my discussion of security and sustainable development in Myanmar - concepts crucial to the domestic and international policies of most countries, both first and third world - I have emphasized that Myanmar is a normal, poor, developing country with all the political, economic and social problems which this entails. Such problems have been exacerbated both by its domestic governance and the policies of the international community towards the country. Myanmar's unenviable record on abuses of both political and civil rights and economic and social rights, from the perspective of current international norms, has placed its government in the position of being perceived to be unable to deliver either 'freedom from fear' or 'freedom from want,' the bases of human security, for the majority of its citizens. Prioritizing state and regime security, it is a long way from achieving that holistic security discussed in Chapter 1 which recognizes that the security of the state is predicated on the security of the people. When the human security of the people is in jeopardy, the state risks becoming a 'failed state;' and 'regime security' is usually washed away in the torrent of social, economic and political chaos. The parlous conditions for human security in Myanmar have consequently led to the polity being subjected to an abnormal level of cyber and economic warfare from its diaspora and sections of the international community abnormal, because even such poor, developing, war torn, violence-ridden, nondemocratic polities as Sierra Leone or Liberia have not been subjected to the same level of censure from the international community as has Myanmar.

That Myanmar has been singled out for special treatment is a measure of the success of its diaspora in mobilizing international support, when the military government did not hand over power to a civilian administration after the May 1990 elections. It is also a function of the iconic status attained by Daw Aung San Suu Kyi as a result of several periods of house arrest since 1989 and her capacity to symbolize resistance to continued military domination of the nation's political, economic and social structures. Finally, it is an outcome of the fact that the world's only remaining superpower, the US, has chosen to make an example of Myanmar, for being tardy in following the developmental path of its South-East Asian neighbours from military dictatorship to demi-democracy, a developmental 
path which is still ongoing for many of the 10 members of ASEAN. This hostility, in mid-2005, even extended to enactment of legislation in the US Congress, which required termination of funding to ASEAN projects, if Myanmar had assumed the ASEAN chair in 2006-7.

A snapshot of the parlous state of Myanmar's governance was provided on 12 August 2005 by the UN Special Rapporteur of the Commission on Human Rights, Professor Paulo Sergio Pinheiro, in his report to the sixtieth session of the UNGA. In balanced, measured tones, he details the positive steps taken on some socio-economic issues, and the initiatives to curb poppy cultivation, forced labour and human trafficking, but does not resile from direct, detailed commentary on the governance failures with respect to human rights, use of landmines, lack of freedom of association, arbitrary arrest of political dissidents, mistreatment of prisoners and lack of an independent judiciary. His 18 recommendations, based on information received in July 2005, if implemented, would go a long way towards the full restoration of political and civil, economic and social rights in Myanmar. ${ }^{1}$ However, Professor Pinheiro has not been permitted to visit the country since November 2003. There is no indication that his assurance that the UN and the international community stand ready to work with the government of Myanmar, political parties and civil society organizations in effecting national reconciliation and the transition to democracy, has been digested. Nor has there been any direct reaction by the government of Myanmar to his statement, 'By improving its human rights record and governance policies and strengthening its cooperation with international organizations, the Government [of Myanmar] can be assured of support for conflict resolution, political and economic reform, institution- and capacity-building, humanitarian assistance and human development' (see recommendations para.100, p. 20). This does not mean that the government is unaware of the report and its recommendations; merely that it chooses not to take up the proffered olive branch at this time. For, despite the criticisms in Professor Pinheiro's report, its detailing of ongoing abuses of the over 1,100 political prisoners still in custody (despite releases in mid-2005 of more than 200 other political and common-law prisoners) and acknowledgement that since the end of 2004 restrictions on the operations of both domestic and international NGOs have become more overt, the formulations of the recommendations suggest a way forward, out of the current impasse which has adversely impacted on Myanmar's relations with the international community. The report is noticeably lacking in the absolutist positions which have characterized much of the international discourse on Myanmar's problems. It is couched in terms of recommendations, rather than demands - repealing onerous statutes (see recommendation at para. 108, p. 21) which curtail civil and political freedoms - which, if the Myanmar government took steps to implement them, as it has done with enacting legislation to curb the use of forced labour, human trafficking, and money laundering - would be useful steps indicating to the international community a genuine desire on the part of the government to move the country forward, out of its authoritarian governance. If such steps were forthcoming, would the international community, especially the US, respond? What would be the chances of Myanmar 
being treated as a normal, developing country, like some of its peers in ASEAN (Laos, Cambodia, Vietnam), needing the assistance of the international community to bring a better quality of life to its citizens?

\section{Implications of present international policies}

The Myanmar government feels it is an administration under siege from both internal and external enemies. The relocation of key ministries integral to state security upcountry to Pyinmana is one outcome of this perspective. Maintaining legislation restricting freedom of association, freedom of the press, the 1950 Emergency Provisions Act, the 1962 Printers and Publishers Registration Act, Unlawful Associations Act and the 1975 State Protection Law is another obvious indicator of a polity which feels it is under siege from domestic and foreign sources. This legislative framework impacts adversely on all civil and political rights in Myanmar; it goes far beyond the policies of economic autarchy which in early 2005 led the government to reserve all onshore oil exploration for national government enterprises. It is emblematic of the privileging of state security over human security in Myanmar. Professor Pinheiro, in this August 2005 report on the 'Situation of Human Rights in Myanmar' called on the government of Myanmar to 'review and repeal those provisions in the 1975 State Protection Law that allow detention by Executive order without charge or trial' (p. 22). Repeal of such draconian measures will be necessary to underpin any democratic transition process in Myanmar. As long as such legislation remains in force, restitution of civil and political rights in Myanmar remains impossible; and the promised new era in Myanmar's political development, expected to arise from the National Convention processes, will be a case of 'back to the future'.

Ironically, the government of Myanmar could look around some of the established democracies in the industrialized world and see comparable legislation being re-enacted as part of those states' defences against terrorism. In an address to the Isaacs Law Society, the Australian Capital Territory (ACT) Chief Justice Terence Higgins, on 13 October 2005, condemned the Australian government's draft legislation which would confer additional powers on its intelligence agency, Australian Secret Intelligence Organization (ASIO), and give the police unprecedented powers to arrest and hold citizens incommunicado without trial in secret locations for extended periods. This draft legislation empowers the authorities to detain people without charge for 14 days even when a person is not suspected of engaging in, or supporting terrorist activities. Other aspects of the draft legislation make it a crime for those detained to advise their families of their situation or where they are. On 15 October 2005, the ACT Law Society also spoke out in support of Chief Justice Higgins' views, labelling the draft legislation draconian. In an unprecedented move which drew the ire of the Federal Attorney General, the Hon Philip Ruddock, the ACT Chief Minister, the Hon Jon Stanhope, on 15 October 2005, also posted a copy of the draft legislation, which had been provided to him in confidence, on his website (see http://cmd.act.gov.au), on the justification that not only did it breach the undertakings given to him and other State Premiers 
by the Prime Minister, John Howard, but that it was the right of all Australians to be able to read this draft legislation and that it should not be kept secret in view of the potentially enormous impact it could have on the lives of all Australian citizens in undermining their civil rights. Two State Premiers and a former Prime Minister, the Hon Malcolm Fraser, also spoke publicly condemning the draft legislation as draconian and an infringement of human rights laws. Since the legislation was still draft, it was possible, even likely, that it might not pass the Senate in its present form: government backbenchers indicated grave reservations about such draconian provisions. Forced onto the back foot by community backlash, the Australian government then claimed that the draft legislation was a 'work-in-progress' document which would be modified; but public commentary on the airwaves continued to label the draft legislation 'draconian' and to castigate the government for an ill-conceived attempt to railroad the legislation through in secret, without adequate public commentary. Human Rights Watch Asia Director, Brad Adams, commented, 'Putting people under house arrest for a year by a control order is tantamount to jailing people without trial.' In the view of Human Rights Watch, such legislation 'not only threatened Australians' civil liberties, but also violated international law' (The Canberra Times, 14 October 2005, p. 1). Comparable legislation has been enacted in other industrialized Western democracies where reactive pragmatism has taken precedence over long-established principles of civil and human rights. In such a crucible, judicial murder such as that of Brazilian, Jean Charles de Menezes, gunned down by British police in a London railway station in the mistaken assumption that he was linked to the terrorists who perpetrated the underground bombings in July 2005, becomes justified on specious grounds of expediency. The subsequent undermining of public trust in key institutions as a result of prevarication and cover-ups by senior public officials entrusted with preserving human security does not augur well for the continued viability of democratic principles. The very basic principles of Magna Carta (1215), the Petition of Rights (1628) and the Bill of Rights (1689), which have governed the civil and political legislative frameworks in certain Western democracies for hundreds of years, are being discarded, as key Western leaders, elected through established democratic processes, increasingly take on the powers and postures of old-style autocrats. Simon de Montfort and the Barons who forced King John to sign Magna Carta at Runnymede in 1215 must think that this too is a case of Back to the Future. One begins to ask if democratic principles are only skin deep, when they can be so quickly discarded by those entrusted by the electorate with safeguarding them for future generations.

With such moves afoot, how are democracies and dictatorships to be distinguished? Certainly not through the espousal of mere electoral processes; this approach has been patently discredited by Zimbabwe where elections have been manipulated to keep a ruthless dictator in power. The line is becoming increasingly blurred between 'dictatorial' democracies which seem eager to embrace terror politics as justification for discarding the basic underlying principles of the individual's civil and political rights, and 'democratic' dictatorships which pay lip service to electoral and constitutional procedural practice in order to retain the 
established power elites. Zimbabwe is not the only offending polity. Is the concept of the 'rights-bearing individual' (Seligman 1992: 196), which has formed the cornerstone of international human rights policy and law since 1948, being submerged in the politics of fear instigated as justification for the 'War on Terror?' If so, then the focus of international policy since September 11, 2001, whilst allegedly making human security its priority, is again privileging state and regime security over human security, in exactly the same way as does the government of Myanmar; citizens, to whom the state/regime owes a duty of care and a 'responsibility to protect' are being projected as 'enemies of the state'. It is a very fine line that democracies must tread in protecting the security of their citizens that they do not cross the threshold at which the civil and political rights of those citizens are made subservient to the political expediency of the regime in power. When that line is crossed, democracies slide into dictatorships.

It is comparatively easy for the respected UN rapporteur on Human Rights to call for the Myanmar government to repeal its oppressive laws, but will Western governments which are now introducing similarly onerous legislation impacting on civil liberties be ready to repeal their own? Many voices doubt it. There are no 'sunset clauses' envisaged for the draconian legislation discussed above; the War on Terror is being proclaimed to justify the reintroduction of legislated 'state terror' where police are given the power to 'shoot to kill' merely on the possibility that someone they consider may be a threat, may have information on a plot against state security. No proof is required. The unfortunate gap between principle and practice in those Western democracies which consider themselves guardians of human rights norms, seems to be growing wider; it is not likely to encourage the Myanmar government to undertake the required legislative reforms essential to underpin enhanced human security in that country. Myanmar too can point to urban bombings and terrorist activity within its borders as justification for retaining state (and regime) protection laws.

However, in robust democracies such as Australia, the sophisticated institutional underpinning which subjects the actions of politicians to intense public scrutiny, the electoral processes and independent judiciary, combined with laws protecting freedom of association, speech and the press usually provide a guarantee that legislation impacting adversely on citizens' civil and political rights will not be enacted, at least in the form proposed by its sponsors. In the recent case in Australia discussed earlier, the Internet was used with dramatic effect to bring to citizens' attention the draconian proposals which would have undermined their civil and political rights. Such application of the Internet in Myanmar or other dictatorships would be highly unlikely. Moreover, in Australia and other Western democracies, regular free and fair elections, governed by strictly enforced electoral laws, provide citizens with the opportunity to vote against politicians whose actions impact adversely on their civil and political rights. In Myanmar, such robust institutional underpinning is lacking; the very processes and procedures of the National Convention inhibit free and open debate. The National Convention process becomes another vehicle for giving the appearance of popular participation in the country's political life whilst guaranteeing the 
government's desired outcome of continued military control of the country's systems of governance. Commenting on the lack of transparency and capacity for democratic debate in the National Convention, Professor Pinheiro (para. 32, p. 8) states,

[T] he very procedures and conditions under which the National Convention operates involve restrictions on and violations of the rights of its civilian participants. The procedural code, order 5/96, issued in 1996, outlaws any criticism of the convention and provides for imprisonment of up to 20 years and the imprisonment of related organizations for those who violate this code.

Myanmar will clearly remain at the dictatorial end of the democratic institutional parabola, even at the conclusion of the National Convention processes. Robust Western democracies intent on enacting legislation which similarly impinges on the civil and political rights of their citizens would not be providing good examples to such an authoritarian regime, if they continued to allow themselves to slide towards the dictatorial end of the parabola.

The international civil and political rights regime embedded in international law since 1948, privileges the individual. However, as Professor Simon Bronitt (The Canberra Times, 14 October 2005, p. 1), ANU academic and a specialist in international human rights law states, these new legislative initiatives in Western democracies are reverting to the collective approach: the punishment of a person because of the group to which he (or she) belongs, rather than for what he (or she) has done on his (or her) own recognizance. In Chapter 1, I discussed the call by James Mayall and others for greater international recognition of group rights; this approach arises from this very problem in that the individual's life, civil and personal liberties and right to the pursuit of happiness is so often impugned by the group or collective context to which he/she belongs. As Seligman (1992: 196) has warned, 'The squaring of justice and solidarity, of private interest and public good, remains the problem of civil society and of citizenship in the modern world... [However] an attempt to return to an ethical solidarity not based on the idea of the individual as autonomous moral agent leads nowhere (or rather has led to some of the most horrible murders of this murderous century [i.e. the twentieth century])'. Seligman (1992: 200-2) highlights the difficulties with a 'Western liberal-individualist model of civil society' taking root in multi-ethnic societies (such as Eastern Europe) where the religious institutions have played a very different role from what they have done in Western Europe. He questions the viability of the idea of civil society in a political sense 'in societies whose terms of collective membership and solidarity are not those of an ideology of individualism (as in the United States)' (ibid.). In the Age of Terror, the relationship of the individual - person or state - to the wider collective identity remains the problem for civil society. As established Western democracies enact new draconian legislation more evocative of fifteenth century Spain than of the UDHR, group rights seem to be dramatically reduced. 
Yet it is these very group rights, especially of indigenous ethnic minority peoples, which have attracted so much of the international censure of Myanmar. Professor Pinheiro notes (p. 3) the continuing reports of serious human rights violations against Myanmar's ethnic minority peoples. When the National Convention reconvened 17 February-31 March 2005, some 1,071 out of 1,083 invited delegates from eight community groups (political parties, representativeselect, ceasefire groups, intellectuals and intelligentsia, peasants, workers, national races and State service personnel) participated; this included representatives from six of the legally recognized ethnic minority parties. However, two others, the Shan Nationalities League for Democracy and the Shan State Kokang Democracy Party did not participate. Nor did the main opposition party, the NLD. Professor Pinheiro marks the need for inclusiveness, openness of discussions, and rolling back of restrictive procedural measures, if the National Convention processes and any Constitution which results, are to have credibility in the international arena. At the present time, and despite the participation of some of the ceasefire groups and ethnic minority representatives, the National Convention processes fall short of adequately redressing civil and political rights in Myanmar. The seven-point 'road map' announced in August $2003^{2}$ may be eventually implemented in its entirety, but the substance of 'democracy' will be missing.

How can this situation be improved? Gellner (1994) looks to 'civil society' rather than democracy, as being a more useful set of concepts by which to measure steps towards improved human security and well-being. In Conditions of Liberty: Civil Society and its Rivals, he emphasizes the economic wellsprings from which he believes civil society grows. He cuts through the Gordian knot of whether restoration of democracy in authoritarian states requires restoration of civil and political rights to precede that of economic and social rights. Civil Society, he argues, "is markedly superior to a notion such as "democracy", which, though it may highlight the fact that we prefer consent over coercion, tells us precious little concerning the social pre-conditions of the effectiveness of general consent and participation' (Gellner 1994: 211). Here he gets down to what I call the necessary 'institutional underpinning' to enable authoritarian polities to move towards the democratic end of the parabola: Is the 'consent and participation' freely given or derived from coercion? If the latter, then clearly no movement along the democratic spectrum has occurred. Since the end of the Second World War, many authoritarian polities have incorporated the word democratic in their formal state identities, without practicing democratic norms in their institutional life. Hence Gellner prefers the social and economic complexities inherent in civil society to indicate the openness or otherwise of a country's systems of governance. Defining civil society, he argues,

Civil Society is a notion which serves a double function: it helps us understand how a given society actually works, and how it differs from alternative forms of social organization. It is a society in which polity and economy are distinct, where polity is instrumental but can and does check extremes of individual interest, but where the state in turn is checked by institutions with 
an economic base; it relies on economic growth which, by requiring cognitive growth, makes ideological monopoly impossible. This is its location on the map of possible forms of social organization.

(Gellner 1994: 211)

Moreover, he suggests,

Civil Society is based on the separation of the polity from economic and social life. ... The autonomy of the economy is needed, not merely in the name of efficiency... but so as to provide pluralism with a social base which it cannot any longer find anywhere else. It requires intellectual or ideological pluralism: the growing economy which is indispensable to the system is impossible without science, and science is incompatible with a cognitive picture of the world which is socially sustained, enforced and endowed with a priori authority.

(Gellner 1994: 212)

Where polity and economy are fused into one state identity, as in socialist Myanmar or pre-1989 Eastern Europe, civil society struggles for existence; and civil and political rights, as well as economic and social rights are submerged in mantra upholding the state identity. In Gellner's experience, totalitarianism required total domination of the economy as this prevented the emergence of independent centres of power capable of challenging the authoritarian powerbase. Thus, in his theoretical framework, 'Political authoritarianisms, even totalitarianisms, which tolerate an autonomous economy, thereby unwittingly also create a Civil Society, or at least the social potential for the emergence of a Civil Society' (Gellner 1994: 145).

On the other hand, if the economy is left free, or encouraged to operate on freemarket terms, it will become too powerful for the authoritarian centre to control (ibid. 147). Current China watchers observe this dynamic and wonder when and how the balance between market economy energies and China's totalitarian identity will tip so far in favour of the former that its Communist party hierarchy will be relegated to history. International policy is presently geared to encouraging the change to happen gradually and naturally, in response to the country's own internal politics. Why should this approach not be taken with respect to Myanmar which in practical terms is so closely aligned with China? That is, why should not the international community consider Myanmar a normal developing country transitioning out of authoritarianism, whose transition would be accelerated by a buoyant economy and vibrant civil society? Such a change in international policy would of course require a reversal on economic sanctions inhibiting trade and investment with the country. In turn, this would mean possible loss of face, not for Myanmar, but for those Western countries which have hitherto espoused the absolutist approach. Since this would be difficult, if not impossible in terms of domestic constituencies and activist groups in the US and the UK, a way forward needs to be found which achieves a win-win, rather than win-lose for both Myanmar and its opponents. 


\section{Towards a more civil society?}

Current international policy based on sanctions and isolation is not only irrelevant, but also incapable of facilitating that democratic governance in Myanmar which is purported to be the objective of the policy. In effect, the country's leadership benefits from such an international policy: not only does it engender nationalistic support for the military regime, but also it serves as a convenient focus for anti-Western, anti-colonialistic propaganda (Badgley 2004). It could be said, that in large measure the policy of sanctions and isolation has in effect undermined the chances of the NLD ever being able to come to power in Yangon. Not only is the NLD, in the minds of many Myanmar people, associated with foreign powers (in a country which still sees the traumatic colonial experience as the yardstick against which everything else is measured), but also because of its support for sanctions the NLD is associated with the apparent economic hardship which impacts on the most vulnerable socio-economic sectors of the society, whilst having no impact at all on the wealthy elite. Economic inequality, as Ehrenberg (1999: 247) argues, mitigates against a vibrant civil society and the development of institutions able to hold governments to account. In effect, current international policy works against the objectives it wishes to foster.

International financial and economic sanctions, it is argued in this book, express symbolic disapproval and provide a 'feel good' effect for the sanctioner. But, by restricting the businesses of the sanctioner from investing in the target country, sanctions also reduce the leverage of the sanctioner and adversely impact on its potential influence in moving the country away from its authoritarian governance systems. Western economic sanctions enable the businesses of those countries which disagree with the policy to benefit. This is especially obvious in the case of Myanmar's neighbours, Thailand, India and China. ${ }^{3}$

In view of Myanmar's borders and geopolitical position, sanctions are an ineffective instrument of foreign policy. Myanmar has robust trading relationships with its Asian neighbours (James 2004a), which strongly disagree with the sanctions approach. Despite being recently (mid-2005) urged by Washington to modify its policy towards Myanmar, Thai Prime Minister Thaksin Shinawatra declined to oblige. Being close to the issues, and unable to afford the dire consequences of state failure in Myanmar, its neighbours are conscious that the only way to approach the problem is to invest in the country, to support the rebuilding of its socio-economic fabric through economic development which provides the resources for institutional development; to support the rebuilding of its education system (dismantled during the Ne Win era 1962-88) to assist the country develop a skilled workforce capable of sustaining its economic growth, and to play a key role in fostering Myanmar's re-integration into international society. Many of Myanmar's neighbours have come from the same position in which Myanmar now finds itself; they recognize the issues as ones they have themselves confronted in managing their own development away from overt military dictatorship. Of the 10 members of ASEAN of which Myanmar became a full member in 1997, few are fully fledged democracies, yet they receive international 
developmental assistance and are not subject to the same level of hostility in the international arena as is Myanmar. Their collective identity and shared anti-colonial history place them in the best position to be able to persuade Myanmar, within the ASEAN norms, to develop a system of governance more commensurate with the expectations of the original members of ASEAN.

In this context, civil society in Myanmar is nascent and resurgent. It is growing through a variety of professional associations, religious associations, special interest associations and ethnic minority development associations. This is distinct from the State-sponsored incipient political party, the USDA with its over 16 million members; or the Myanmar Maternal and Child Welfare Association, with its over 3 million members, which, although it does very good work at grassroots level in terms of poverty alleviation and health education, has been placed at the service of government development policies. Civil society in Myanmar needs to be supported, internationally, to increase its capacity to contribute to the political and socio-economic development of the society. Whilst a number of US private foundations and religious groups work with civil society in Myanmar, it would be advantageous for this type of interaction to be gradually increased.

Further leadership changes appear imminent in Myanmar. For international support, interaction with and assistance to the (oppressed) education, health and civil society sectors to be effective, and even permitted, it will be necessary to decouple such initiatives from policies espoused by the displaced Khin Nyunt faction. Whoever is ultimately in charge in Yangon, is likely to continue to cultivate good relations with both India and China, foster their investments and look to them most importantly as buffers against any US threats of intervention.

Being able to count on China, has been the most important card in Myanmar's deck since 1988 and the single most significant reason why current US/UK international policy towards Myanmar is ineffective. This is unlikely to change. China's most important regional strategic interest lies with the future of Taiwan. China is highly unlikely to go along with any international policies which would result in her back door being exposed to a Western-oriented regime aligned with Washington, and which could in future contribute to 'encirclement' of China. In other words, the sanctions policy suits the Myanmar leadership; they know that they can safely get along with doing whatever they wish in terms of running their own country, their own way. The sanctions policy also suits China, as, by impeding the growth of civil society, economic and institutional development, it ensures that no democratic regime will come to office in Yangon. The sanctions policy suits Myanmar's regional neighbours who can also safely get along with the business of investment without too much competition from US firms. It also suits Washington; status quo ensures that a weak, unstable democratic state sharing a border with Muslim Bangladesh on its western rim, and southern Thailand on the south-east rim where a full-scale Muslim insurgency has re-emerged, will not arise to add to the difficulties of prosecuting the 'War on Terror'. The losers of course are the millions of Myanmar citizens who are not closely allied with the military government and who struggle to educate their children and want a better future, within their own cultural and national parameters. 
Achieving a more civil society in Myanmar requires policies privileging human security to displace those currently geared to prioritizing state and regime security. Yet the state too has a major role to play in exercising its responsibility to protect its citizens from ill-being - both socio-economic and civil-political arising from its non-optimal institutional development. It will require a major conceptual leap for the Myanmar leadership to acknowledge that the security of the state derives from the security of the people.

Given the history of hostile relations with the West, how can movement be achieved which enables both sides to save face? It is not realistic to assume that a solution can be found, or that the required transformation in Myanmar's governance can be sustained, without such an approach. Certainly, any moves to ameliorate international policy towards Myanmar will need to be initiated gradually, taking due cognizance of any further leadership changes in the Myanmar government. As part of a more effective policy package towards Myanmar, consideration should be given to making some support available to civil society groups; to increasing the educational opportunities for the younger generation through re-instituting the scholarship schemes for Myanmar, which are available to other developing countries in the region, and to changing the sanctions regime to a visa-restriction regime which applies only to certain individuals against whom there is substantial evidence of human rights abuses or other criminal activity. Consideration should also be given to measures which will foster economic development in Myanmar as the crucible from which a viable middle class and robust civil society can grow. International policy might then be re-focussed on the well-being of the majority of Myanmar's citizens and disengaged from its present primary focus on one heroic individual. It will then be possible for the international community to encourage a policy matrix which fosters the rebuilding of Myanmar's socio-economic fabric, in recognition that this will create the institutional underpinning for the emergence of sustainable transformation in Myanmar's political governance.

Since this multi-pronged approach presupposes a change in the value systems which have dominated Myanmar's authoritarian political culture, some cognizance will need to be taken of that sector in Myanmar society which is most credited with upholding its present system of governance: the military. If the principles of civilian control of the military, fundamental to robust systems of democratic governance, are to become established within Myanmar corporate identity (as they are slowly doing in Thailand), it will be necessary to expose the middle ranks of the Myanmar military to training opportunities in the academies of the West - West Point, Sandhurst, Duntroon - similar to those already available to its ASEAN neighbours. It should be noted that the principles underpinning the drafting of Myanmar's new constitution currently do not provide for civilian control of the military in any future democratic government. An entrenched culture of human rights abuses against the civilian population, perpetrated largely by the military and the police, cannot be changed overnight; it will require a sustained programme of culture change to bring this about. It certainly will not happen through policies of isolation and sanctions which, in effect, remove any possibility of alternate influences being brought to bear. 


\section{Conclusion}

Simultaneously with the above multi-pronged approach, interactions on international 'public goods' programmes such as drug control and eradication; HIV/AIDS prevention and control; prevention of money laundering and human trafficking and intelligence sharing within the War on Terror context should be enhanced. If the international community can change its perspective to consider Myanmar a 'normal' developing country transitioning from socialism, and, instead of sanctions and isolation policies, embrace policies which encourage economic development, tourism, international interactions and 'opening up' the country, transforming Myanmar's value systems to create a climate for the robust institutions needed to uphold democratic governance will become possible. Both Myanmar and the international community might then move towards a 'more civil society'. 


\section{Notes}

\section{Introduction: holistic and human security - concepts and contexts}

1 Michael Gove, 'Ideology, not tribal hate, spurred massacre,' The Australian, 8 September 2004, p. 12, writes,

When we contemplate the horror of Beslan, we should realize there is nothing specifically Muslim, Chechen or "other" about the deliberate mass murder of children. In the lifetime of our parents, in the heart of the Christian West, men who had been brought up to enjoy the fruits of European civilization killed infants as casually as a gardener dispatching greenfly. The enormity of what happened in Beslan last week, like the actions of Nazi Germany, still defies understanding.... But the history of Europe in the past century reminds us that it is only a short distance from Beslan to Belsen. The motivation in both cases was not ancient antipathy, but modern ideology ... Although the Chechens have a long history of resistance towards those they consider enemies, the nature of modern Chechen terror has far more in common with contemporary fundamentalist practice than historic Caucasian resistance.... When Russia did grant Chechnya greater autonomy in the 1990s, it was only to find the territory become a launch pad for fundamentalist groups intent on exporting slaughter well beyond their borders. When others abuse their freedom to threaten your safety there is a need to act.

2 UN Special Envoy to the Sudan, Jan Pronk, has cited the Sudan government's complicity in the Arab militia's 18-month terror campaign of murder and rape against African villagers over arable land and other issues. Amnesty International has called on the UN Security Council to hold the Sudanese government to account for gross human rights violations in Darfur which is seen as a critical test of the Security Council's resolve to compel the Sudanese government to abide by a UN resolution calling on it to disarm the militia and stop attacks against civilians. See AFP, Reuters, 'Darfur crisis a critical test for UN, says Amnesty', The Canberra Times, 4 September 2004, p. 18.

3 See http://www.mofa.go.jp/policy/human_secu/t_fund21/what.html (30 June 2003). In line with this policy, in March 2003 USD 1.2 million was made available through the Trust Fund for Human Security for 'Drug Control and Development in the Wa Region of the Shan State' in the Union of Myanmar, implemented by the United Nations Drug Control Programme (UNDCP). The press release by the Japanese Ministry of Foreign Affairs states that the 'goal of this project is to support the opium poppy eradication plan of the Wa Special Region where opium has been largely produced and the living standard is low. Activities include training in construction of irrigation system, developing flat paddy fields, and introducing double cropping of rice. This project is expected to contribute to increasing the food security of opium farmers, improving their living standard, and eventually, eradicating opium poppy cultivation.' See http://www.mofa.go.jp/announce/ announce/2003/3/0328-2.html 
4 The sensitivity of newly decolonized states to the principles of state sovereignty and non-interference in the internal affairs of nation states was recognized by the International Commission on Intervention and State Sovereignty (2001), The Responsibility to Protect, Ottawa: International Commission on Intervention and State Sovereignty, p. 12. The report states, "the norm of non-intervention is enshrined in Article 2.7 of the UN Charter - a sovereign state is empowered in international law to exercise exclusive and total jurisdiction within its territorial borders. Other states have the corresponding duty not to intervene in the internal affairs of a sovereign state. If that duty is violated, the victim state has the further right to defend its territorial integrity and political independence. In the era of decolonization, the sovereign equality of states and the correlative norm of non-intervention received its most emphatic affirmation from the newly independent states.' The difficulty for the international community has been how to reconcile state sovereignty and non-interference with the frequent spectacles of appalling human suffering precipitated by states against their own citizens. This led the Commission to propose a set of parameters for international intervention which would 'operationalize' the concept of human security. It is noteworthy that in the wake of the tsunami disaster at the end of 2004 which has taken over 250,000 lives in 10 countries and seen unprecedented international assistance rendered to the affected countries both at governmental and people levels, the Australian Prime Minister, John Howard, moved quickly to assure the Indonesian government that the presence of unarmed Australian troops in the separatist-prone region of Aceh was purely for humanitarian assistance, with no implications for support to the Acehnese separatist groups (Gerakan Acheh Merdeka - GAM) which he pointedly described as an internal matter for the Indonesian government. Still sensitive to Australian military intervention in East Timor in 1999, the Indonesian government at first called for all foreign troops to be withdrawn from Aceh in three months, then on 17 January 2004 reversed its decision.

5 The number of 'interventions for human protection purposes' has increased since the early 1990s. Dunne, Hill and Hanson (2001) view this new direction in international policy as signalling a marked change in the international order 'where sovereignty no longer acts as a wall behind which human rights abuses can be committed with impunity'. See Dunne, T., Hill, C. and Hanson, M. (2001) 'The New Humanitarian Interventionism', in Hanson, M. and Tow, W. (eds) International Relations in the New Century: An Australian Perspective, Melbourne: Oxford University Press, pp. 93-116.

6 At the 1993 Vienna World Conference on Human Rights, the former UN Secretary General, Boutros Boutros-Ghali, asked, 'What are the links between development and the enjoyment of economic, social, cultural, civil and political rights?...I wish to emphasize here that civil and political rights and economic, social and cultural rights are equally important and worthy of attention.' See United Nations (1993) World Conference on Human Rights: The Vienna Declaration and Programme of Action, New York: UN Department of Public Information, pp. 6, 12. Mary Robinson, former UN High Commissioner for Human Rights, assessing the 'rhetoric and reality' of the rights debate stated, 'As High Commissioner I have a responsibility to bridge the gap in perceptions about human rights and foster a rights-based approach across the whole spectrum of civil, cultural, economic, political and social rights, to enhance understanding of the right to development as the synthesis of other rights and to include women's rights as human rights.' She reminded the international community that there are 'some countries with an exemplary record of civil and political rights who continue to neglect economic, social, or cultural rights of many of their people. And there are countries that have made great strides in economic and social rights, but have failed to make progress on civil and political rights. We do wrong to emphasize some rights and neglect others.' Mary Robinson (1999) 'Addressing the Gap between Rhetoric and Reality', in Yael Danieli, Elsa Stamatopoulou and Clarence J. Dias (eds) The Universal 
Declaration of Human Rights: Fifty Years and Beyond, Amityville, New York: Baywood Publications Co., pp. 426-7.

Her position supports the intercivilizational approach fostered by Yasuaki Onuma: the 171 nations who adopted the Vienna Declaration under the observation of some 1,500 Civil Society organizations approached human rights not from a Western-centric, but from a transnational perspective. Whilst economic, cultural and social rights, as well as civil and political rights, provide data on which to make a meaningful assessment of the state of well-being of human populations, the electoral processes by themselves, amidst the framework of participatory governance, cannot sustain a viable democratic political fabric. Yasuaki Onuma (2000) 'Towards an Intercivilizational Approach to Human Rights', in William Krull (ed.) Helen Schoop (trans.) Debates on Issues of Our Common Future, Gottingen: Velbruck Wissenschaft, p. 62. It is necessary to build and strengthen the socio-economic and political institutions which support that fabric. On this issue, Boutros Boutros-Ghali stated, 'The supervision and monitoring of elections do not in themselves constitute long-term guarantees of democratization and respect for human rights.' UN (1993) Vienna Declaration, p. 20.

7 I use 'capabilities' in the same sense as does the Nobel Prize-winning economist, Professor Amartya Sen, in his book (1999), Development as Freedom, New York: Alfred A Knopf, that is, the enhancement of all human potential through a framework of democratic governance, respect for human rights, and inclusive, participatory development.

8 In qualifying 'intervention', the ICISS asserts, 'whatever the motives of those engaging in the intervention, it is anathema for the humanitarian relief and assistance sector to have this word appropriated to describe any kind of military action. The Commission has also been responsive to the suggestion in some political quarters that use in this context of an inherently approving word like "humanitarian" tends to prejudge the very question in issue - that is, whether the intervention is in fact defensible' ICISS (2001) Responsibility to Protect, p. 9.

9 Proposals to expand the composition of the 15-member Security Council mooted in late 2004 include providing for six new permanent members without the power of veto, plus three members appointed for 2-year terms. Countries being suggested include India, Brazil, Germany, Japan and South Africa amongst others. It is unlikely, however, that such expansion would be able to counter the weight of the five permanent members, the original nuclear powers who were the victors in the Second World War, China, Russia (USSR), Britain, United States and France, who retain their veto power. Some proposed new members are vigorously lobbying to have the veto power extended to them. Without the veto power, the asymmetrical power structure may not be materially altered, and the proposed changes are not considered to enhance the decision-making propensities of the Security Council. Amidst calls by certain US senators for the resignation of current Secretary General, Kofi Annan, over the alleged corruption scandal involving 'oil for food' for former Iraqi dictator, Saddam Hussein's sanctions impaired country, are not so strident calls for the US to pay its long overdue UN membership fees. Its failure to pay up, and strident attacks on the UN, increasingly raises the prospect of the US bringing about the demise of this experiment in international governance, just as US non-membership of the earlier League of Nations is widely considered to have been a key element in the demise of that organization.

10 Paul Collier and Anke Hoeffler (2000) Greed and Grievance in Civil War, New York: World Bank Policy Research Working Paper No. 2355 identify two models of civil conflict: greed and grievance. In the 'greed model' civil conflict has analogies with organized crime, generates its own income from extortion and receives 'start-up' finance for rebellion from the diaspora living in OECD countries who are usually wealthier than the population in the country of origin and do not suffer the consequences of the conflicts they finance. The objective in this model is said to be predation. In the 'grievance model' the impetus for rebellion derives from inter-group hatred, 
political exclusion and desire for vengeance. This model exhibits a high degree of economic inequality, marginalization and exclusion from the political processes.

11 Shannon Tow (2004) 'Southeast Asia in the Sino-U.S. Strategic Balance', Contemporary Southeast Asia, 26(3): 434-59 contends that the international policies of smaller South-East Asian states are driven by the overriding desire to maintain their autonomy and not be co-opted or coerced by either China or the US, whilst maintaining political and economic relations with both major powers consistent with their own short- and long-term national interests. By analysing what she calls the 'nuances' (Tow 2004: 249) of South-East Asian states' foreign policies she rejects the notion that these are driven by the geopolitical perspectives of the two Asia-Pacific major powers.

12 Acharya (1998: 212) argues that it is easy to be sceptical of the ASEAN Way; ASEAN is not as informal an institution as it claims to be. ASEAN summits are marked by 'formal agenda, structured meetings, and legalistic procedures [which] are quite evident in ASEAN's approach to political and economic cooperation (particularly the development of the ASEAN Free Trade Area and the recently created Southeast Asia Nuclear Weapon-Free Zone Treaty). But the ASEAN brand of "soft regionalism" which relies primarily on consultations and consensus, serves as a useful, if not entirely accurate, symbol of its collective uniqueness, and has been a source of considerable satisfaction and pride for ASEAN members in the international stage. ASEAN members have become so confident of their approach that they have offered it as the basis for a wider framework of confidence-building and conflict reduction in the Asia Pacific region. Eg The ASEAN Regional Forum, a newly created security institution for the wider region, is self-consciously emulating ASEAN's norms (such as those contained in the Treaty of Amity and Cooperation) and procedures (especially the consensus method). This has meant the rejection of the "heavily institutionalized" CSCE/OSCE with its Conflict Prevention Centre, Missions of Long Duration, and the Valletta Mechanism for Peaceful Resolution of Disputes, as a possible model for conflict resolution in the Asia Pacific region, as suggested in early Russian, Australian and Canadian proposals.'

13 Ramesh Thakur (1997) suggests that collective security has always been ephemeral. He argues, 'The Veto clause thus effectively negates the collective security aspect of the UN. The reality of the Cold War, which registered profound irreconcilable... differences between the two blocs, produced a frequent resort to the veto clause by whichever permanent member saw its or its clients interests under threat from an assertive majority coalition....

Collective security is a system designed to deter and defeat inter-state aggression, as against Kuwait by Iraq. It fails to match the requirements of civil strife, which is the more common type of conflict to confront the UN. Collective security requires multilateralism; successful military operations require centralized command and control.' Thakur, R. (1997) 'From National to Human Security', in Harris, S. and Mack, A. (eds) Asia-Pacific Security: The Economics-Politics Nexus, St Leonards: Allen and Unwin, p. 70. In effect, collective security privileges the major powers, who are not deterred from taking military measures against smaller powers in the name of national security. Such a development signals a return to the Hobbesian view of international society, brutish and nasty.

14 For trenchant discussions of the ASEAN Concord II intention to establish an ASEAN economic-, security- and socio-cultural community, mapped out at the Ninth ASEAN summit in Bali in November 2003, see R. J. Ferguson (2004) 'Policy Prospects for Participant Regional "Development" ', Contemporary Southeast Asia, 26(3): 393-415 and A. L. Smith, (2004) 'Solidifying Regional Cohesion, Advancing External Linkages', Contemporary Southeast Asia, 26(3): 416-33. While Ferguson remains sceptical that the announcement represents anything more substantial than rhetoric, Smith emphasizes ASEAN Concord II's contribution to developing ASEAN's external regional linkages with China, India and Japan. Smith thus looks at ASEAN Concord II as a regional building block for further policy development. 


\section{The security discourse in Myanmar: regime, state and people}

1 Burma (as the country was called before 1989) withdrew from the NAM at the 1979 conference in Havana when it considered that the NAM policy was being skewed towards the then USSR.

2 New Light of Myanmar, 24 November 2004.

3 For an informed analysis of this security mantra and its symbolism in state-building and regime-survival terms, see Tin Maung Maung Than (1998) 'Myanmar: Preoccupation with Regime Survival, National Unity and Stability', in Muthiah Alagappa (ed.) Asian Security Practice: Material and Ideational Influences, Stanford: Stanford University Press, pp. 390-416. Regarding the state's contested concept of security, which is conflated with regime security, Tin Maung Maung Than argues that it will 'have to be modified to incorporate societal elements if the goals of national solidarity and political stability are to be achieved. At the regional and international levels, it remains to be seen whether the cautious steps taken thus far to incorporate regionalism into the traditional neutralism are sufficient to keep up with the dynamic regional and international developments that impinge upon state security' (ibid. p. 416). In the 6 years since this article appeared, the military Government's hold on power has strengthened, despite its external critics, continuing Western (US, UK and EU) sanctions and a fragile economy. A detailed discussion of these and related issues is set out in Badgley, J. (ed.) (2004) Reconciling Burma/Myanmar: Essays on U.S. Relations with Burma, vol. 15, no. 1, Seattle: National Bureau of Asian Research.

4 See Pedersen, M., Rudland, E. and May, R. (eds) (2000) Burma-Myanmar: Strong Regime, Weak State? Adelaide: Crawford Publishing House.

5 New Light of Myanmar, 26 September 2004.

6 An extended discussion of social development initiatives undertaken by the Myanmar government since 1997 is set out in James, H. (2003) 'Cooperation and Community Empowerment in Myanmar in the Context of Myanmar Agenda 21', Journal of Asian Pacific Economic Literature, 17(1): 1-21.

7 Seng Raw, an ethnic Kachin and director of the domestic NGO, the Metta Development Foundation, argues, 'Given that this is the first positive initiative to emerge after more than a decade of political stagnation, the ethnic leaders feel that all parties should come together to work toward a common goal. Challenging the road map at this juncture, they believe, is not a constructive exercise. The National Convention will be meaningful to the extent that all political players are willing and able to participate in the process in good faith. Against this backdrop, ethnic leaders say that they are preparing to come up with safeguards to ensure that a history of failure does not repeat itself, and that the political legacy of the Panglong spirit lives on.' For further discussion, see Seng Raw (2004) 'The Role of Minorities in the Transitional Process', in Badgley, J. (ed.) Reconciling Burma/Myanmar: Essays on U.S. Relations with Burma, vol. 15, no. 1, Seattle, WA: National Bureau of Asian Research, pp. 67-72.

8 Analysing the role of war in state creation and the endurance of military government in Burma/Myanmar since 1962 despite contrary moves amongst the country's regional neighbours, Mary Callahan (2003: 8) writes, 'Although warfare debilitates fragile states, war also builds states, as the scholars of European absolutism have demonstrated. In the Burmese case, unlike that of Europe, warfare built a state thoroughly beholden to war fighters.' This view continues to be reflected in the post-18 October 2004 statements emerging from the military subsequent to the announcement in late November 2004 (reconfirmed in mid-2006) of the continued house arrest of Daw Aung San Suu Kyi. The military considers that if the NLD General-Secretary ever became the national leader she would preside over the break-up of the Union through granting autonomy to various ethnic minority groups. Since the creation and preservation of the state has been the military's main objective and justification for its continued role in government, the military leadership in Myanmar is determined to prevent such Balkans-style disintegration at all costs. This perspective informs their ideological 
opposition to Daw Aung San Suu Kyi whom they identify with the former colonial power, Britain. However this position is specious; some of the ceasefire groups have already been granted de facto local autonomy by the Myanmar government without prejudicial impact on the Union. The position clearly is another reiteration of justification for retaining power.

9 See Heather Rae (2002) State Identity and the Homogenisation of Peoples, Cambridge: Cambridge University Press, for an informative discussion of state policies in these eras unleashed on individuals of these communities for the purpose of enhancing state security.

10 Chris Hann and Dunn (1996: 10-14) draws attention to the fading popularity of the term, Civil Society, in Eastern Europe where it was resurrected post-1989, but its continued vitality in other parts of the world operating under authoritarian systems of governance where 'the expansion of democracy is articulated explicitly in terms of civil society'. He emphasizes the lack of uniformity even in contemporary Western models of civil society, and draws attention to the need 'to shift the debates about civil society away from formal structures and organizations and towards an investigation of beliefs, values and everyday practices'. Hann calls for greater involvement of anthropologists in the academic civil society discourse and proposes the term 'Civil Anthropology' to apply to the investigation of the moral codes and tensions underpinning social cohesion within communities (Hann 1996: 24).

11 In this connection, two former senior members of the NIB, Col. Than Tun and Col. San Pwint, are said to have been placed in solitary confinement.

12 Amitav Acharya (1998: 209-10) emphasizes the fact that ASEAN's normative framework 'served as the basis of its collective opposition to Vietnam's invasion and occupation of Cambodia during the 1978-89 [sic] period. ASEAN, which had earlier sought to co-opt Vietnam into a system of regional order founded on these norms, now saw the Vietnamese invasion as a gross violation of non-use of force in inter-state relations. As a result, ASEAN not only organized an international campaign to isolate Vietnam, but also spearheaded the diplomatic search for a settlement of the Cambodia conflict that would undo the Vietnamese occupation. In this process, ASEAN lost no opportunity to present itself in a more favourable international light vis-à-vis Hanoi. Vietnamese "expansionism" was contrasted with ASEAN's "good-neighbourliness" and desire for regional political stability (implying territorial and political status quo in Southeast Asia), Vietnam's alliance with the Soviet Union with ASEAN's professed goal of a Zone of Peace, Freedom and Neutrality (ZOPFAN) in Southeast Asia (SEA), Viet Nam's intense nationalism and ideological fervour with ASEAN's pragmatism and developmentalism, and Viet Nam's military suppression of the Cambodian rebels with ASEAN's efforts for a political settlement of the conflict. ASEAN's Cambodia posture served not only to enhance its international stature (hence giving it a distinctive identity in international diplomacy), but also to strengthen its intra-mural solidarity. It motivated ASEAN members to overcome conflicting security interests and territorial disputes within the grouping, thereby moving it further in the path toward a security community.'

13 For a detailed discussion, see Jurgen Haacke (2003) ASEAN's Diplomatic and Security Culture: Origins, Development and Prospects, London and New York: RoutledgeCurzon, chapter 7. Following Acharya, and Alagappa, Haacke examines the sociological aspects ASEAN security culture and the symbolic power of the ASEAN Way which was challenged both by the Thai proposal for flexible engagement and by Dr Mahathir's public criticism of the SPDC following the 30 May 2003 incident. His criticism was perceived to deliberately infringe the norm of non-interference in the internal affairs of member states, although he had himself been the subject of similar criticism from the former Philippines president, Estrada, over his dismissal and subsequent jailing of former Deputy Malaysian Prime Minister, Anwar Ibrahim.

14 On the power of symbols in community building, Acharya (1998: 210) comments, 'Deutsch's work suggests that institutions and organizations by themselves cannot sustain a security community in the absence of a common devotion to some symbol or symbols representing this security community. Prominent ASEAN symbols in the 
arena of conflict-management are the so-called "ASEAN Spirit" and the ASEAN Way. These symbols have been invoked on countless occasions to reduce bilateral tensions among the ASEAN members.' Along similar lines, Ylva I. Blondel (2004) Power of Symbolic Power: An Application of O'Neill's Game of Honour to Asymmetric Internal Conflict, Department of Peace and Conflict Research, Uppsala University, analyses how the challenged state mobilizes its symbolic power to manage external and internal perceptions of its honour and the comparative status of the challenger. This principle has obvious applications to the internal dynamics of Myanmar's domestic politics and its external foreign relations, and was notably employed by ASEAN in its relations with Vietnam in the 1978-89 era as noted earlier.

15 Concern that the international human rights framework has been wilfully set aside by the George W. Bush administration's policy of detaining prisoners for lengthy periods without trial at Guantanamo Bay, Cuba, has led to the release of a number of prisoners including the Australian citizen, Mamdouh Habib, 'rendered' to Egypt for torture on behalf of the US before finally being released after more than 2 years in captivity. Democracies, as well as dictatorships, are not immune to trampling on human rights when their leaders feel that domestic political mileage is to be gained by policies arising from the securitization of human rights.

\section{The seven horsemen of the apocalypse: strategies for effective poverty alleviation amongst the peoples of the poppy cultures}

1 Paul Keal (2003: 7) points out that there is no fixed definition of 'indigenous peoples' which remains a contested term; however, the most widely cited definition is that of the UN Special Rapporteur Jose Martinez Cobo:

Indigenous communities, peoples and nations are those which, having a historical continuity with pre-invasion and pre-colonial societies that developed on their territories, consider themselves distinct from other sectors of the societies now prevailing in those territories or parts of them. They form at present non-dominant sectors of society and are determined to preserve, develop, and transmit to future generations of their ancestral territories, and their ethnic identity, the basis of their continued existence as peoples, in accordance with their cultural patterns, social institutions and legal systems.

[see Jose Martinez Cobo, 'Study of the Problem against Indigenous Populations', vol.v, Conclusions, Proposals and Recommendations, UNDoc E/CN 4/Sub 2 1986/7, Add 4, paras 379 and 381, cited by Sarah Pritchard (ed.) (1998) Indigenous Peoples, the United Nations and Human Rights (London: Zed Books). See also Sharon Venne (1998) Our Elders Understand our rights: Evolving International Law Regarding Indigenous Rights (Penticon, BC: Theytus Books.)] Keal (2003) argues that This means an indigenous person is

One who belongs to these indigenous populations through self-identification as Indigenous (group consciousness) and is recognized and accepted by these populations as one of its members (acceptance by the group). Moreover, Cobo's definition encompasses four key inter-related factors common to most definitions of indigenous peoples: subjection to colonial settlement, historical continuity with pre-invasion or pre-colonial societies, an identity that is distinct from the dominant society in which they are encased and a concern with the preservation and replication of culture. Of these, continuity with pre-invasion societies and social, cultural and economic conditions are written also into the definitions contained in Article 1 of the ILO Convention 169 and the Draft of the Inter-American Declaration on the Rights of Indigenous Peoples. This includes peoples brought involuntarily to the New World. Belonging to non-dominant sectors of society and being concerned with the preservation of culture are attributes indigenous people share with minorities that might not be indigenous. 
2 Professor Ross Buckley, at the Tim Fischer Centre for Global Trade and Finance, Bond University, in his article, 'A Nomination that's Likely to be Deeply Divisive', The Canberra Times, 21 March 2005, suggested that an appropriate candidate for President of the World Bank would have been Ernesto Zedillo, former President of Mexico, who heads the Centre for the Study of Globalization at Yale University. Buckley points out that Wolfowitz, the architect of the Bush Administration's policy of using pre-emptive military action to impose democracy on the Muslim world, 'has no development experience' and 'plainly believes in promoting liberty and freedom by war'. Moreover, Buckley, who insists that the World Bank's core mission is to assist poor countries fight poverty, states that the Bank 'needs to be led by an exceptional person with a deep understanding of the huge challenges of development for poor countries and with the ability to persuade the rich countries of the world to support this task even more generously than in the past'. Paul Wolfowitz, Buckley asserts 'is not that person'. Not only was process ignored, he argues, but also it was subverted: the Bank's 24 Executive Directors whose responsibility it is to select the next President initially rejected Wolfowitz when his name was informally circulated amongst them some time previously. However, with the support of the Europeans, Wolfowitz has subsequently been confirmed.

3 Renard (2001: 138) commenting on the transformation processes in the north of Thailand after 30 years of development projects, observes, 'I realized that hill people have no alternative but to accept the state in particular and lowland society and "development" in general. Where the hill people were once beyond the reach of valley kingdoms and their rulers, such conditions no longer exist.'

4 See James (2005) Governance and Civil Society in Myanmar: Education, Health and Environment, London: RoutledgeCurzon, pp. 33-4. Even under the country's 5-year development plan announced in 1997, one third or 2,575 $\mathrm{km}$ of the projected new roads were to be only laterite; about one ninth or $1,648 \mathrm{~km}$ were to be sealed roads; and the majority or $5,253 \mathrm{~km}$ were to be left as metalled roads. Historically of course, transport through these regions was either on foot or by mule caravan used to transport the illicit drugs. Government helicopters can be used only outside the monsoon season (May-October); in practical terms, not after March when the upward wind drafts make it too hazardous to use helicopters.

5 Keal (2003: 122) observes, 'Land is a crucial element in the recovery and continuation of indigenous ways of life. Land, culture and government are inseparable in traditional philosophies; each depends on the others, and this means that denial of one aspect precludes recovery of the whole.... The importance of the link between land and culture was recognized by the UN Human Rights committee.'

6 The dilemmas of the UN human rights regime for indigenous peoples, both with respect to the legal distinctions made between 'people', 'peoples' and 'groups' by the ICCPR and ICESCR and the way states interpret these to fend off secession movements; and the substantive issues involved in group rights being defined as human rights in order to reduce states' propensity for ethnocide have been cogently delineated by Keal (2003). He argues, 'The right to self-determination in particular is a collective right that cannot be claimed by individuals.... If there are just human rights then groups of indigenous peoples have no legally defined rights that set them, their culture and place of attachment, apart from others. Without safeguards for collective or group rights cultural identity is at risk. Article 6 of the Draft Declaration [on the Rights of Indigenous Peoples] stipulates the collective right to live as distinct peoples. Indigenous peoples argue that group rights are the only way to ensure protection against ethnocide' (Keal 2003: 126).

And 'In the end indigenous rights might be a species of human rights, but if they are, they require human rights to be redefined in ways that include the collective human rights of groups.' Moreover, although the right to self-determination is set out in Article 1 
of both the ICCPR and the ICESCR, 'neither Convention was written with indigenous peoples explicitly in mind. Any appeal to these instruments must be made on the grounds that indigenous groups belong to the general category of "peoples". Consequently the Draft Declaration on the Rights of Indigenous Peoples seeks to establish the right of self-determination as a specific right of "indigenous peoples" (Keal 2003: 141). Whether it becomes formally enacted, will be determined by whether the member states of the UN, which have substantial indigenous ethnic minority peoples within their borders, can be convinced that the reconceptualization of self-determination is not a passport to secession and fragmentation of their sovereignty. In Myanmar's case, this has been the critical issue since the 1947 Panglong agreements set the scene for subsequent secession demands by the Shan and Kayah, and underpinned both the long years of civil war and the contemporary political impasse with its underlying question of whether the future corporate identity of the state of Myanmar will be that of a centralist or federalist state. The clear answer from successive governments in Yangon since 1948 is that the corporate identity of the state is, and will remain, a centralist one; this has not however, silenced demands, particularly from the Shan groups, for a federalist system. The dichotomy - centralist versus federalist - continues to be played out within the National Convention processes. Further implementation of a reconceptualized approach to self-determination within the life of the nation state, along the lines of that accorded the Palaung and Pa-O in Upper Myanmar, is not likely to happen soon; nor for the larger ethnic minority groups (approximately 23 per cent of the population) such as the Shan, Kachin, Karen, Mon, Kayah, Chin and Rakhine each of whom is associated with a formal administrative division or 'state' at regional government level. The application of the experiment in self-determination in Myanmar appears to be only to some of the smaller groups of indigenous ethnic minority peoples.

7 According to the Myanmar Information Sheet, No. D-3018 (I) 3 May 2004, the joint Myanmar-US opium poppy survey team visited Mongpan, Hsiseng, Namsan, Leikha and Mongshu townships in Shan State (South); Mongpyin, Kengtung and Mongkhat in Shan State (East); the Wa regions of Khwinmar, Mongmaw, Namtit, Lonhtan, Panglong and Hopan; the Kokang regions of Laukai and Shaukhaw in Kutkai Township; and Kaungkha in Shan State (North). The team surveyed poppy fields and collected poppy bulbs and raw opium, met with poppy growers in the regions and interviewed them, studied the destroyed poppy fields and viewed agriculture and livestock breeding tasks being carried out within the poppy-substitution programme. The following summary of drug-confiscation activities listed in the same information sheet as evidence of Myanmar's cooperation with regional and international authorities to interdict the flow of illegal drugs across its borders into neighbouring countries is typical of such news items; whilst exact quantities may be subject to question, the mix of drugs is indicative of the extent of the problem. Crop-substitution programmes are only one aspect of the solution; the other clearly is closing down the illegal factories operating within the rugged terrain of Myanmar's border regions. The summary in Myanmar Information Sheet, No. D-3018 (I) 3 May 2004, reports, 'In the drug elimination sector, there were seizures of 1,806 cases of opium, 5,694 cases of heroin, 1,924 cases of marijuana, 2,637 cases of stimulant tablets, 142 cases of ephedrine, 12 cases of diazepan tablets, 81 cases of cough syrup, 10 cases of acetic anhydrate, 72 cases of chemical liquid and 16 cases of chemical powder. In doing so 7,333 kilos of opium, 1,357 kilos of heroin, 1,651 kilos of marijuana, $100,064,106$ stimulant tablets, 13,997 kilos of ephedrine, 456 litres of cough syrup, 596,066 tablets of diazepan, 20,533 litres of acetic anhydride, 60,903 litres of chemical liquid and 62,641 kilos of chemical precursors were seized. Likewise, 33 opium refineries and 69,562 acres of poppy plantations were destroyed in the 5-year period [of the first 5-years (1999-2004) of the 15-year drug-elimination plan]'.

8 This is not the first time Burmese/Myanmar governments have sought to implement a poppy-substitution programme in the northern opium-producing regions. In 1965, 
following the 1 October prohibition on the sale of opium in Shan State that year, the military government of the late General Ne Win announced a Kokang Development Project to improve the socio-economic conditions of the primary opium-producing areas. This initiative was stillborn in the wake of the Burmese Communist Party (CPB) seizure of Kokang in 1968 and renewed hostilities thereafter. In the mid-1970s after the Ne Win government's agreement with the US for cooperation and assistance on drug-suppression operations, the joint United Nations Fund for Drug Abuse Control (UNFDAC) Burma Programme for Drug Abuse Control, supported establishment of poppy-substitution programmes at Monghsat in Shan State and in Kachin State. Cash crops such as peanuts, tea and coffee were favoured; livestock development was encouraged and efforts made to establish a dairy cattle industry and apiaries. Under this programme, three 5-year poppy-reduction programmes, 1976-80, 1981-6, 1986-91, were funded. From 1974-88, by means of 15 separate bilateral pacts, the US provided Burma with over USD 86 million to fund projects aimed at reducing the supply of poppy (Renard 1996: 50). In 1916, the British colonial government had also made some desultory attempts to promote sericulture among the Kachins as an alternative to poppy cultivation, attempts which Renard (1996: 38) characterizes as 'uninspired'. When Western anti-narcotics aid was discontinued after the 1988 suppression of the democracy uprising, 'opium cultivation continued in the opium-growing areas such as Kokang, much as it had for over a century previously' (ibid. 69).

9 A termed coined in 1971 by Marshall Green (US Assistant Secretary of State, later Ambassador to Thailand) at a press conference 12 July 1971, three days prior to the announcement that President Richard Nixon would visit China in February 1972. Thus the US 'implicitly recognized the absence of opium in China' (Renard 2001: 8). Kokang was ceded to Britain under the 1897 Peking Convention with China. Having been the northern base for the CPB since 1968, in 1989 Kokang units of the CPB revolted against their aging Burmese leadership (which fled to China) and signed a peace accord with the N.E. Command of the Burmese Army. The period 1968-89 had seen Kokang become a battleground for Ka Kwe Ye (KKY) militia, drug warlords such as Lo Hsing-han, and the Burmese military. The former CPB units of Kokang, Wa and Shan formed the Burma National Democratic Alliance Party. Yang Li (1997: 106) states that following meetings with General Khin Nyunt and military intelligence chiefs at Kunlong, on 3 January 1990 an agreement was drawn up between the Yangon military regime and the Kokang units by which Kokang was classified as a Special Area and the ex-CPB operative, Peng Kya Shen, was recognized as the chief civil and military administrator. Under the agreement, some 1,000 men of the Kokang units would draw their salary and supplies from the Burmese army which had to seek permission from the Kokangese before entering Kokang territory. Yang Li asserts that the carrying of arms by the Burmese military within Kokang territory was forbidden. This is interpreted as 'autonomy'. Subsequent to the ceasefire agreement, the Myanmar government granted the Kokangese Myanmar citizenship (Renard 1996: 69). It remains to be seen how robust such an arrangement is in the wake of the 18 October 2004 purge of Khin Nyunt and his faction. The Burmese military has shown on earlier occasions (1962/3) that it can move swiftly to remove local leaders whom it considers a challenge to the authority of the centralizing state.

10 Recognition of the international dimensions of Burma/Myanmar's drug trade have long since addressed McCoy's (1991) concern that effective drug-suppression operations in the Golden Triangle needed to take into account that opium poppy cultivation was not merely a domestic Burmese/Myanmar problem but that it required cross-border cooperation, concerted action by international agencies and funding assistance to the Burmese/Myanmar authorities to successively interdict the flow of drugs onto the international markets. Linter (2000) claims that in the late 1980s opium production in Burma 'more than doubled'. He quotes US statistics to the effect that Burma's 1987 harvest yielded 836 tons of raw opium, which, by 1995, had increased to 2,340 tons. 
He claims, 'Satellite imagery showed that the area under poppy cultivation increased from 92,300 hectares in 1987 to 142,700 in 1989 and 154,000 in 1995 (Bureau for International Narcotics and Law Enforcement 1987, 1989, 1995)' (Lintner 2000: 165) with a parallel rise in heroin output from 54 tons in 1987 to 166 tons in 1995; and a rise in the production of methamphetamines (yaa baa) and ecstasy (yaa ee) from the same laboratories on the Thai-Myanmar border. Lintner also notes that the ephedra plant used to make ephedrine grows wild all over the southern China-Yunnan frontier and is sold locally 'without the need for extensive overseas networks as in heroin' (ibid.). The potential heroin output from the crop, from 54 tons in 1987 to 166 tons in 1995, made 'drugs the country's only growth industry' (ibid.). However, Renard (1996: 92-3) doubts the provenance of the US statistics and suggests that they have more to do with registering displeasure over the political developments in 1988 and subsequent years, which saw the suppression of the democracy movement in the country. Lintner's claim that drugs are the country's 'only growth industry' is an exaggeration (James 2003: 1-21) driven by a similar political perspective.

11 James George Scott (1851-1935) was born in Dairsie, Scotland, where his father, the Reverend George Scott, was the Minister. After the death of his father when Scott was 10 years old, his mother, who had some independent means, 3 years later took Scott and his elder brother Robert to Mannheim, Germany, for their education. Robert later became Master of St John's College, Cambridge University, to which J. G. Scott's papers were later bequeathed. J. G. Scott himself went to King's College School, then to Lincoln College, Oxford. After missing a scholarship by one place, he went East, and in the mid-1870s appears to have spent some time teaching English in Malaya then writing journalism and teaching in British Burma. In 1881 he was back in England, trying again for a scholarship to continue studies in law at the Inner Temple, but missing out again, once more went East and joined an expedition to Tongking in 1883. In 1886, he joined the Burma Commission and thus set out on a career which led to his being made CIE in 1892 and KCIE in 1901. In the course of several expeditions to the Shan, Wa, Kokang and Trans-Salween regions, he defeated the Limbin Confederacy which was challenging British authority in the Northern Shan States, and saw the Limbin Prince (an illegitimate son of the late Crown Prince, Kanaung) off to exile in India. He was an accomplished author; his volume, The Burman: His Life and Notions. written under the nom-de-plume of 'Shway Yoe' (first published 1882) went through many editions. It remains his best known and most readable work. In 1891 he was directed to write the encyclopaedic, Gazetteer of Upper Burma and the Shan States, for which he was promised Rs. 2,000. The fee was never paid. Having been responsible for bringing the Shan States under the British umbrella, in 1902-3 he escorted their Sawbwas (hereditary rulers) and wives to the Delhi Durbar. To supplement his meagre income in retirement in Surrey where he lived with his third wife, G. E. Mitton, he wrote a series of unsuccessful novels. None of his later writings achieved the fame of The Burman.

12 As a result of a joint China-Myanmar drug-abuse survey on both sides of the porous border, it was agreed between the two countries that detoxification and rehabilitation services would be implemented. Detoxification hospitals currently exist at Putao, Myitkyina and Mong Pauk (where I spoke with some of the Shan patients), on the border with China, which funds the hospital in an area where most people speak Chinese as their first language. The hospital name is written in Chinese characters.

13 Renard highlights the comparison with Thai policies for the development of the ethnic minority people living in the mountainous northern regions. 'In this formerly remote area that is now undergoing rapid change, it remains to be seen how effective these efforts will be. Even in Thailand, where the political situation is much more stable, highland development has been unable to resolve many of the problems facing the hill people there' (Renard 1996: 87).

14 Some of the indigenous peoples in northern Myanmar, for example the Kachin and Palaung, smoked opium mixed with chopped tobacco; others cooked it to a thick syrup, 
added chopped plantain, then made it into balls which were placed on the tip of a pipe. (Renard 1996: 17)

15 In the 1949-57 period, the Thai police general and strongman, Pao Sriyanond (McCoy's cherub with a Cheshire cat smile), controlled most of the opium trade transversing Thailand, in collaboration with key Thai-Chinese businessmen. Pao fled to Switzerland when Sarit Thanarat took power in a coup in 1957. Pao was then one of the wealthiest men in the world. His compatriot, Chin Sophonpanich, founder of the Bangkok Bank, fled to Hong Kong. The flight of money with Pao and Chin is said to have brought Thailand to the brink of bankruptcy. This did not deter Sarit Thanarat during his term as strongman, 1957-63, from similarly amassing a vast fortune, a trait in turn emulated by his successors in the Thai dictatorship, Thanom Kittikachorn and Prapass Charusatien. Pao, Sarit and Prapass all had early career linkages with the Northern Command of the Thai army, thus having the opportunity to establish their interactions with the KMT warlords and drug barons of the Golden Triangle. Lintner (1994: 156) points out that after Iran and China banned poppy cultivation in 1946/9, Pao needed alternate sources of supply; the KMT filled this void. By 1955, the Thai police under Pao 'had become the largest opium-trafficking syndicate in Thailand, involved in every phase of the narcotics trade; with forces exceeding 48,000 they were larger than Sarit's regular army of 45,000. Although Sarit formally abolished the Thai Opium Monopoly, established in 1855, in response to British pressure during the era of King Mongkut (1851-68), Lintner (1994: 158) notes, 'But narcotics related corruption, and private business activities, were already rampant in Thailand; no serious attempts were made to stop the enormous traffic from the poppy fields of Burma and northern Thailand down to the sea lanes. Thailand remained the most important transshipment centre for Burmese opium, and Bangkok remained the major Asian drug capital.' This pattern continues up to the present time.

16 See Renard (1996: 49-59) for a discussion of drug-suppression initiatives taken by the governments of independent Burma in the period 1948-88. In 1974 a formal agreement was signed between Ne Win and the US to cooperate on drug-suppression operations, for which the US provided a number of Bell Helicopters and contributed towards a UNFDAC poppy-replacement programme. Norway also contributed funding to this programme. Ne Win's predecessor, $\mathrm{U}$ Nu, a devout Buddhist, on 11 February 1948 had announced a plan to eradicate poppy, and in 1953 established an Opium Enquiry Committee which, in the face of the growing insurgencies, met with little success. In 1964, the Opium Enquiry Committee sought statistics on the number of addicts in the union, the causes of addiction, the need for substitute crops, and revision of the existing laws. The cultivation and sale of opium in the Shan States was prohibited as from 1 October 1965. With the closure of opium dens and elimination of the special exemption for growing opium in Eastern Shan States, 'opium kings' became 'opium insurgents'. In face of the growing threat after 1968 from the CPB, which drew income from the narcotics trade, international anti-narcotics agencies were prepared to help Burma, motivated, as Renard points out by the 'flow to US and Europe', not by the problems in Burma where opium users, in 1977 were said to be 20,269 registered users, mainly older and tribal people; however, heroin usage was already spreading amongst the younger generation. 'Besides helicopters, US aid included fixed-wing aircraft and communications equipment that supported Burmese military operations, called Mohein, which were directed against refineries and base camps near Tachilek, just opposite Thailand's northernmost point. Mohein also aimed at interdicting caravan routes by which opium was transported to these camps' (Renard 1996: 52). The 1974 Narcotic and Dangerous Drugs Law prohibited the cultivation, production, possession, trafficking, transfer and sale of narcotic drugs with penalties ranging from 10-years imprisonment to death, but called for compulsory medical treatment for all users. 'The 1974 law provided a grace period until 1979 for persons who had made their living by opium cultivation and the manufacture of crude opium ... to find alternative sources of income' (ibid.). 
17 This counter-insurgency policy, called Pya Lei Pya, was initiated in 1963. It was designed to deny the insurgents access to food, funds, intelligence and recruits. Villagers in a designated area were forcibly moved to a 'safe' (i.e. Government controlled) or 'white area'. The designated 'black' zone was then subject to aggressive clearance operations and any person caught within that area was considered an enemy of the state.

18 See Lintner (1994: 92-106) for a succinct account of the 'secret war' in northern Burma, 1950-1, when the CIA supported the KMT as part of Washington's wider policy to contain the spread of Communism in South-East Asia, and its direct links to the outbreak of the Korean War. After Truman sacked Macarthur in April 1951 for the latter's overt policy to try to foster an all-out war with China, the CIA continued to secretly fund and supply the KMT with assistance from Taiwan. Lintner writes that in May 1951

two divisions of heavily armed [KMT] troops climbed the grassy, barren mountain range that separates Burma's Kokang district from China. They then entered Yunnan. The first unit, led by Li Mi himself, targeted Kengma, which was captured within a week. The other column advanced from the Wa hills south of Kokang towards Teetan, another border town in Yunnan. Li Mi's men continued their advance, and headed for Mengsa, sixty kilometers northeast of Kengma. The aim was to capture the airfield in Mengsa, the closest to the Burmese border, and set up a base area there.

Following the first debacle at Kengma, the PLA had regrouped and counterattacked. Li Mi was beaten, and within less than a month in Yunnan, he retreated to Mong Mau in the northern Wa hills. On hearing about the defeat, the second column also turned back and never even approached Teetang. Undercover Burmese intelligence agents, who nervously monitored the fighting, reported that unidentified four-engine aircraft had dropped supplies on the KMT bases in Kokang and around Mong Mau throughout the campaign. It is not known where the planes came from, but they must presumably have taken off from airfields in northern Thailand, which were frequently used by Taiwan intelligence agencies for flying supplies to Mong Hsat, and to survey the Yunnan frontier. Following the first, abortive attempt to invade Yunnan, a second foray was mounted in July. This time a 2,000 strong force was mustered under the command of General Liu Kuo Chwan, the Mong Hsat-based commander of the 26th Army. The area chosen this time was closer to the bases along the Thai border: Sipsongpanna in southern Yunnan, just across the frontier from Kengtung... [but] the PLA was too tough; the local people did not welcome the KMT as they had expected.

(Linter 1994: 101-2)

In April 1952, the US Ambassador in Rangoon, David Key, resigned 'in disgust' that his government had not even advised him of the secret war in the north. Key is said to have commented that US support for Li Mi's operations in Burma had 'cost us heavily in terms of Burmese goodwill and trust' (Linter 1994: 106). That legacy continues until today.

19 Scott's Diary of a Tour to the Shan States (1897) records his receiving the following instructions:

If you are able to enter into friendly communication with any of the chieftains of the outlying Wa circles, there will be no objection to your doing so. The GovernorGeneral in Council entirely concurs in the Lieutenant-Governor's view that it is unnecessary to interfere with the Was by the establishment of a post in their midst or otherwise, and that there is little to be gained at present by sending further expeditions into the Wa country.

(From Secretary to the Government of India, W J Cunningham, to Chief Secretary to the Government of Burma [Scott U.L. 1.5]) 
However, on the successful conclusion of his expedition, he gleefully records these words of approval:

$[\mathrm{H}]$ is tour... has added very considerably to our knowledge of the Wa country and its people.' From Chief Secretary Government of Burma (E S Symes) to Secretary Government of India. Symes' summary of the expedition records: 'Mr. Scott left the Salween on the 2nd January [1897] and, proceeding by slow marches, reached Loinung on the 13th February. At Loinung he received a letter from Wei, the Chenpien Prefect, whom he had invited to meet him at Mongpa, expressing his regret that he was unable to do so without instructions from Yunnan. Here also $\mathrm{Mr}$ Scott received various conflicting accounts of the position and strength of the Chinese garrisons on the frontier, and in order to verify the facts with regard to these garrisons, and also to give the Prefect a further opportunity of meeting him, he decided to proceed to Monghsaw. After passing through the British villages of Hsupso, Pangpe and Hinkwang, at all of which he was received in a very friendly manner, he, at the last named village, inadvertently crossed the frontier into China and continued in Chinese territory for about 25 miles, re-entering British territory some 5 miles south of Monghsaw. At Mongshaw he was received in a friendly way by the villagers and was visited by Wang, the Military Officer Commanding in the Chenpien Prefecture and by another Chinese Military Officer named Tao. He held several conferences with these two officers and, at their invitation, subsequently proceeded to Monglem. While at Mongshaw Mr Scott received a formal protest from Wei, the Chenpien Prefect, against his march through Chinese territory, but a later letter from that official directed that he was to be escorted with all honour to Monglem and promised to meet him there if authorized to do so from Yunnanfu. At Monglem Mr Scott remained for 10 days, maintaining throughout the most cordial relations both with the Sawbwa and with the Chinese officials. At the end of this time, as there seemed no prospect of a meeting with Wei, $\mathrm{Mr}$ Scott left Monglem and returned to Panghsang. As the results of his tour so far he had ascertained that there were no longer any Chinese posts in what we regard as British territory, he had learnt the position and strength of the Chinese posts near the border, he had fully explained the frontier as claimed by us to the Military Officer Commanding in Chenpien, and had obtained from that officer an undertaking that no further military operations should, pending delimitation, be undertaken (except to resist aggression) west of that frontier; and finally, he had ascertained the precise position of Monghsaw and obtained an accurate map of a portion of the border land hitherto little known.

However, the Wa states were never tightly integrated into the British colonial administration, and remained largely autonomous, as long as they received the occasional British column with friendly gestures.

20 In 1892, during a tour of the upper Mekong Valley, Scott had observed the trading arrangements taking place between the local hill tribes and the Chinese Haws. He wrote, 'I may say that these Chinamen are the first I had met anywhere in or close to Siamese territory other than immigrants by way of Bangkok. Most of the caravans that we met near the salt mines, and later towards Muang Sai, ply between Yipang, as well as other northern districts of Chienghung and the territories of Luang Prabang and Muang Nan. They bring down opium, which they sell or exchange for raw cotton. The trade consists almost entirely of these two articles, the opium being disposed of and the cotton collected on the way amongst the hill people. The greater part of the trade of these regions is therefore local, and foreign goods have very little share in it; nor are any imported goods likely to compete with the local demand for raw cotton in the north and opium in the south.' His interest in the opium trade continued throughout his career.

21 In 1900 Scott states, 'The market price for a kilogram of opium was 6-7 rupees just after the harvest and 10 rupees during the off-season' (Scott and Hardiman 1901, pt. 2, 
vol. 3: 263). Renard calculates that based on 'a production of 80 metric tons, something over 1 million rupees was traded for opium. In 1903, about 6 rupees equalled one pound. Therefore about 160,000 pound would be a high estimate of what could be expected to be reaching Kokang as part of the opium trade at that time in an average year. A sum of at least half that should have been reaching opium traders in the Wa area' (Renard 1996: 28-9). Kokang was ceded to the British by the Chinese government, in 1897 at the Treaty of Peking as supposed compensation for alleged infringement of the 1894 boundary agreements.

22 See Owen (1934), Trocki (1999) and Scott (1969) for a brief discussion on the ancient origins of poppy traced to the Swiss Alps, its spread to the near East in prehistoric times, and eastward dispersion by Arab traders during fourth-eighth centuries; its medicinal and ritual usages and short life cycle from poppy flower to opium 'cakes'; widespread usage in Moghul India prior to the Portuguese irruption in the sixteenth century and the Portuguese readiness to incorporate opium as a regular item of trade underpinning imperial expansion. Scott asserts, 'The time and place of the discovery of opium cannot be fixed. Among relics of the Stone Age lake dwellers in Switzerland, and therefore dating from about 4,000 years ago, the seeds and large seedheads of the cultivated poppy have been found. But Europeans were not the original discoverers. Opium was known in the Middle East long before. In Sumerian ideograms of 6,000 years ago the poppy is referred to as the plant of joy. It probably reached Asia Minor from Egypt. If Egypt was not its birthplace it provides the earliest records of its uses and properties. It was at first a monopoly of the priests, valuable in their mysteries.... Later, when Egypt became the centre of medical knowledge, it was widely used and studied by physicians... During ten days of its life of less than one year, Papaver somniferum [i.e. the opium poppy] produces a highly complex chemical which is beyond the capacity of our laboratories to reproduce, and after those ten days destroys it' (Scott 1969: 2). Trocki (1999: 14-16) provides further detail of the poppy's uses in prehistoric times: 'The earliest evidence of opium usage dates from around 3100BC. The fossilized remains of the seeds and seed capsules of Papaver somniferum (the opium poppy) were discovered in ancient lake beds in the Alpine region of western Europe. There is a cluster of sites dating from late Neolithic and early Bronze Age in parts of what are today Switzerland, France and Germany. In these places, archaeologists have found fossilized poppy seeds, poppy seed cake and poppy capsules. The sites are associated with settlements of lake-dwellers variously identified as the Michelsburg, Cortaillod, Horgen, Lagozza and Pfyn cultures which flourished between 3000BC and 2500BC.' However, Trocki (1999: 14-16) states, 'There is no conclusive proof that these people were using the seeds or seed capsules for their psychoactive properties... The presence of the capsules in a number of these sites suggests an awareness of the plant's mind-altering properties. There are few other uses for green poppy capsules. These are the source of the sap from which all opiates are made. It thus seems reasonable to assume that these lake-dwellers were making use of the alkaloids produced by the opium poppy. It is possible that these lake-dwellers not only used opium, but they may even have been the ones who developed the plant.' Trocki suggests that since there are no truly wild varieties of Papaver somniferum and all known varieties are cultivars for which a wild ancestor no longer exists, the "plant is the product of an extensive and sophisticated process of primitive "genetic engineering" that was accomplished almost five millennia ago'. The poppy was known and used in Greece, around 2000 BC, and appeared in the Fertile Crescent in the second millennium BC. Trocki disagrees with Scott that it was known to the Sumerians. As the industry developed in India, the opium poppy cycle spanned some 18 months from sowing to harvesting and auctions. Blake (1999: 27) states that poppies sown in Bengal in October 1826 (i.e. autumn) would be harvested in the February-April 1827 (i.e. spring) period; then made into 6-inch cakes in the factory during May-September and finally sent by river to Calcutta at the beginning of November. Auctions would be held just after Christmas until July 1828. 
23 At the beginning of the nineteenth century, 1800-21, the India-China opium trade averaged just over 4,500 chests (at 133-60 pounds per chest) per year. In 1821-2 it began to increase rapidly. From 1822 to 1832 some 10,000 cases were exported to China annually. This escalated in 1831-2 to 19,000 chests and then 40,000 chests in 1838-9, on the eve of the first 'Opium War' (Blake 1999: 26). The three way trade - opium for tea and silk - turned a 26 million British pounds Chinese trade surplus in 1800-10 into a 38 million British pounds trade deficit 1828-36 (ibid.). Opium paid for the tea and silk which Britain purchased from China; the duties on the tea sold in Britain paid a large part of the expenses of the Royal navy and financed Britain's imperial expansion. Wong (1998: 353) has shown that in 1856 duties on Chinese tea sold in Britain 'provided 35.7 per cent of the expenses of the Royal Navy; 51.57 per cent in 1857 when Canton was captured; and 57.22 per cent in 1858'. Thus 'Chinese tea financed the war on China' (ibid.). With one sixth of its revenues derived from the opium trade at midcentury (Blake 1999: 123), the Government of India opposed all measures which might deny it continued access to that revenue. In 1857, the year of the Indian Mutiny after which the British Government formally superseded the EIC, Jardine-Matheson wrote to its agent in Bombay, Rustomjee Jeejeebhoy (son of Jamsetjee Jeejeebhoy) on 23 May, stating '2,400 chests per month will meet the demand [for the drug in China] (Private Letter Books, J-M C9/5). Statistics of the Imperial Maritime Customs Service provide the following figures on the amounts of opium imported into China between 1863 (i.e. post-'Arrow War') and 1879, regarded as the high point of the trade:

Piculs of opium imported into China (133 pounds per chest for Patna; 140 pounds per chest for Malwa; 160 pounds per chest for Bengal opium)

Year Amount

$1863-50,087$ chests

$1867-60,948$ chests

$1879-82,927$ chests

It is said that another 20,000 piculs were smuggled into China in each of these years. The figures started to decline a little after 1888 when 82,612 piculs were said to be imported; and again in 1897 (49,309), rising slightly in $1905(51,920)$ just before the Chinese agreement with Britain to start reducing the imports. It is said a further 5,000 piculs imported went 'unreported' in each of these years. By 1911, the year of the Chinese Revolution, the figures had fallen to 27,758 piculs (with 3,000 unreported) ahead of formal British prohibition of the trade in 1917. At the Chefoo Convention of 1876 , the duty on opium was set at $80 \mathrm{HK}$ ticuls per picul, giving a total duty of $110 \mathrm{HK}$ ticuls per picul. Annual value of the opium imports was 30-40 million HK ticuls. See Lodwick (1996: 12ff). Owen (1934: 69) states, 'A picul is equal to 100 catties, each weighing roughly one and one-third pounds. Malwa was packed in chests containing about 140 pounds, while a chest of Bengal weighed 120 catties (160 pounds).'

24 Independent traders were heavily engaged in smuggling the opium out of Gujarat, Rajasthan and the central Indian states. Much of it went out through Daman and Diu. Farooqui (1998: 185-6) has identified at least 17 non-indigenous firms/merchants engaged in the Malwa opium trade 1803-30; and at least eight Portuguese firms/merchants.

25 With opium businesses already operating in Calcutta and Singapore, Sassoons opened a branch in Hong Kong as soon as it became a British colony in 1842. This gave the company a stake in every link in the India-China opium trade except the coastal trade; this final link was provided by Peninsular and Oriental (P\&O) Steamship Company's services in the early 1850s (Le Fevour 1968: 27). Their rise to prominence in the trade was marked by the mid-1850s, characterized by entrepreneurial business practices which included buying in advance unharvested poppy crops in India utilizing experienced agents. Speculating on the Bombay sales and purchasing in agreement with others at the Calcutta auctions, Sassoons adopted the practice of holding their stocks 
for some time in China in order to obtain the best prices. By contrast, Jardine-Matheson's Bombay agents did not buy directly from the poppy cultivators or purchase in advance; as a consequence they lost market share in China to Sassoons by the mid-1870s, and by 1879 were diversifying their interests into shipping, banking and insurance. The financial collapse of their agent in Bombay, Rustomjee Eduljee, in 1872, precipitated Jardine-Matheson's withdrawal from large-scale operations in the opium trade, although some smaller scale transactions on consignment were still being carried out until 1879. In the 1880 s, Jardine-Matheson's took on a different role as mediators between the Chinese 'reform' group at Court, who sought to modernize China with Western technology before it was too late, and the European centres of business expertise. The firm continued to do business in China until 1951 when their last chief executive, Walter Keswick, received his exit visa from Mao's government.

26 Carol Benedict (1996) has traced the periodic outbreaks of bubonic plague and the parallel development of the international opium-trading networks. Noting that opium poppy had long been cultivated in western China since the seventh century Tang dynasty, she claims that before the nineteenth century it had been grown in the mountains of Yunnan only on a limited basis. Its spread amongst the general population followed the introduction of Patna and Malwa opium by the English trading companies, but, since this was too costly for most Chinese, demand for the cheaper domestically grown drug increased. Whilst the first record of opium cultivation in Yunnan is dated to 1736 , production for the domestic market increased from the 1820 s, impelled by improved transportation along the West River region between Yunnan and Lingnan, and development of a Cantonese distribution network in Guangxi and Guangdong. Benedict believes that evidence of the "consolidation of the Yunnan-Lingnan opium trade dates to about 1840' (Benedict 1996: 51-5). The town of Beihai was, by the midnineteenth century, the major centre for the Yunnan-Lingnan opium trade. Ten years before the 'Arrow War', opium from Guangdong yielded around 8,000-10,000 piculs per year. John Anderson (1876) on the 1868 expedition to Tengyueh with Edward Bosc Sladen found opium from Yunnan in Burmese markets in Bhamo and Mandalay. Opium growing in Yunnan in the early nineteenth century may have increased in response to the recession conditions in the province in the 1790s following exhaustion of the copper deposits and downturn in the mining industry. When British explorers, Colquhoun $(1883,2: 137)$ and Gill passed through western Yunnan in 1883, they witnessed the great devastation caused by plaque in the towns between Kunming and Dali. Gill (1883: 272) states, 'the plain of Fu-Piau... had been entirely depopulated by an extraordinary disease, of which the symptoms were like those of the plague, and which had, during the months of August and September, carried off upwards of a thousand people.... Now ... the disease had ceased at that place, and had moved in a southerly direction to Niu-Wa, where it was raging.'

27 In 1902, the Archbishop of Canterbury, Frederick Temple, sent the Prime Minister, Lord Salisbury, a memorial from the Anti-Opium Societies in England signed by leaders of the Church of England, the Church of Ireland, the Church of Scotland, the Congregational, Baptist and Methodist Churches and the Society of Friends, stating that the opium trade 'hurt other aspects of British commerce in China' and 'fostered profound feelings of hostility to British subjects', a viewpoint attested to during the Boxer Rebellion in 1900 when over 79 missionaries and their children were killed, despite the fact that missionaries had been in the forefront of the fight to halt the opium trade (Broomhall 1930: 221). Medical missionaries had been instrumental in assembling the scientific data on opium addiction to confront the apologists for the trade with its widespread harmful effects. Lodwick (1996: 31-63) notes that while missionaries kept the opium question before the British public and government until the trade ended, they 'had little to do with suppression of the use of opium because they did not interact with the key decision makers in the Chinese government, and little understood how the Chinese government worked'. Ironically, at the time of the Communist takeover in 
1949, several missionaries, including women, were publicly executed in various parts of China because they were regarded as 'agents of imperialism'.

28 At the time of the Japanese advance across South-East Asia in 1941, the colony with the largest number of opium smokers was said to be Malaya $(130,000)$. French Indochina had 120,000 addicts, followed by the Dutch East Indies $(60,000)$. Thailand, though still an independent kingdom, but largely under British influence and tied to British commercial treaties, had operated a government monopoly since the Bowring Treaty of 1855. It had around 80,000 opium addicts (Jennings 1997: 93). Unable to access opium from India and Turkey after the outbreak of the Second World War, Japan drew on the 200,000 tons of Iranian opium shipped to Shanghai in 1937, in addition to the areas under poppy in Manchukuo (Manchuria). The leading opium merchants in Shanghai were said to have fled to Hong Kong and elsewhere before the Japanese intrusion.

29 Walker (1991: 148) observes that opium undermined the morale of Japanese troops in Burma during the Second World War. He states, 'As the OSS learned from the exploits of Detachment 101, opium's place in Upper Burma remained unassailable despite the ferocity of the war there. Tokyo's forces failed to turn the trade to their economic advantage and were left trying to induce the Shans, somewhat successfully, and the Kachins, whose antipathy to the Japanese the Allies would call upon, to collaborate in return for additional supplies of opium to help them best their Chinese competitors in the commerce.' He quotes Colonel William Peers and Dean Brelis of OSS Detachment 101: 'Our mission to use opium was based on the fact that it would give our troops a certain amount of freedom, of buying power; we did not question it as just or unjust... Simply stated, paper currency and even silver were often useless, as there was nothing to buy with money; opium, however, was the form of payment which everybody used. Not to use it would spell an end to our operations' (OSS Detachment 101).

30 Walker (1991: 182) comments that Burma at independence in 1948 'was not closely linked to the global narcotics trade'. Its annual production was said to be in the vicinity of 30 tons of raw opium (Lintner 1994: vii). On 11 February 1948, Premier U Nu, a devout Buddhist, announced his plan to eradicate poppy growing and rehabilitate addicts. On 24 July 1948, he announced his decision to keep open 100 official opium shops, and to restrict the influx of illegal opium from India, Yunnan and rebellious areas of Shan States, much to the disappointment of Robert Lovett, Acting US Secretary of State. (Walker 1991: 182). In 1953, U Nu established an Opium Enquiry Committee, and in 1955 the Compulsory Registration Act for users. In face of the spreading insurgencies, these early efforts met with little success. In 1961, U Nu presented a plan to the UN asking it to recognize poppy growing in the Trans-Salween states as legal, as a way for farmers to make a living, and in view of similar conditions applying to India where it was cultivated 'for medicinal purposes'. The UN refused on the grounds that the insurgencies precluded adequate controls. At the time, a Burmese, U Thant, was Secretary General of the UN and another Burmese, U Nyunt, had been appointed President of the General Assembly. Renard (1996: 49) recounts that 'The U.N. decision so irritated the Burmese government that it refused to cooperate with U.N. control measures for many years and refused to meet with U Thant to discuss the issue.' The matter still rankled in 1972, when Burma under the military government of Ne Win, did not sign the Protocol Amending the Single Convention on Narcotics Control. Myanmar is now a signatory to the UN Convention against Illicit Traffic in Narcotic Drugs and Psychotrophic Substances. Walker (1991: 182) notes that at the country's independence in 1948 'U.S. narcotics policy tended to be out of touch with conditions in Burma.'

31 A final attempt to maintain prices for the drug was made by a group of India-based merchants in league with corrupt Chinese politicians, characterized by Owen (1934) as the 'Peking clique'. Called the 'combine', or syndicate, it endeavoured to purchase some 1,500 chests of opium for resale on the Chinese domestic market at a time when a large part of China's domestic supplies had been officially eradicated. However, when the links with the corrupt politicians were exposed there was such a hue and cry from both the public and the diligent Chinese officials who had taken responsibility for 
eradicating the drug, that, as Owen puts it, 'The Peking clique wilted under the attack.' Witnessed by representatives of welfare and civic organizations, the opium was burned with full public ceremony, lasting 8 days. The final chest of Indian opium was 'given to the flames' on 25 January 1919 (Owen 1934: 351). As in the beginning of the trade, opium and other drugs made their inroads into Chinese and other Asian societies with the overt and covert assistance of corrupt officials, a situation not dissimilar to the situation prevailing in contemporary societies. Yet, if 'opium brokers, merchants and smugglers profited immensely' (Blake 1999: 29) the efforts of the reformers - Prince Kung, Chang Chih Tung, Tang Shao Yi (Owen 1934: 331-2) - should also be remembered as the pioneers of the law-enforcement practices which presently govern the international drug-suppression regime. Corruption knows no international boundaries: from the officials squeezing the early-nineteenth-century Chinese Cohong merchants in Canton (Downs 1997: 80) to the former Executive Director of Macquarie bank in Sydney 2005, corruption is synonymous with the opium and narcotics trade, fed by the enormous illicit wealth - and human misery - it engenders.

32 Demand during the First World War pushed the prices for raw opium to new heights. From a base price for Indian raw opium of 937 yen per chest in 1914; and 1,056 yen per chest for Persian raw opium, the prices rose by 1916 to 2,336 yen and 2,460 yen respectively (Jennings 1997: 43).

33 In the report to the League of Nations, Britain divided the FSS into three parts: in the first, under British control, opium was prohibited in 1923 and used only by registered users in licensed dens; in the second, under the control of the Shan Sawbwas, mostly west of the Salween, there was a policy of control and suppression; in the third, where most of the poppy was grown, suppression was said to be difficult and expensive. Renard has characterized the British report to the League of Nations as 'deliberately obscured' (Renard 1996: 36).

34 In 1959, the Shan rulers agreed to surrender their hereditary rights. In 1961, the Frontier Areas Administration (FAA) was established for parts of the Shan States which had not been subject to Burmese legislation. The FAA was in charge of the Kunlong District bordering Yunnan and composed of the Kokang, Northern and Southern Wa States, and Eastern Frontier Region, including Kengtung, Tachilek and Mong Ton. The 'Shan States' became 'Shan State'.

35 Lo Hsing-han became the dominant drug warlord in Kokang after Olive Yang's removal in 1962. He had been one of her retainers. Placed in charge of one of the KKY militia groups after the assistance he rendered the Burmese army at the 45-day battle of Kunlong Bridge in 1971, Lo fell out with the military government after making contact with the Shan State Army (SSA) in 1973. Seeking to sell some 400 tons of opium to the US government for USD 20 million, he stepped into a Thai helicopter near the Thai border and was instead escorted to a Burmese jail. His subsequent trial was aborted when it seemed likely he would implicate high-ranking officials in his drugsmuggling operations. Sentenced to 7 years jail on charges of treason for contact with the SSA, he was freed under amnesty in 1980. A similar story attends his rival, Khun $\mathrm{Sa}$ (born Chang Chi-fu). Initially an independent drug warlord operating in Wa State, he joined the KKY. His attempt to challenge the KMT for control of the drug trade in the area in 1967 went awry when the Lao Air Force intercepted his drug caravan of 300 mules. He re-established contact with the SSA which led to the Burmese military government arresting him and charging him with treason. He was released from prison in 1976.

\section{Myanmar's external relations in regional context: security enhancement}

1 For an incisive discussion of the distinction between the two approaches as applied to the Asia-Pacific region, see Stuart Harris and Andrew Mack (1997) Asia-Pacific Security: The Economics-Politics Nexus, St Leonards: Allen and Unwin. 
2 Confrontation between supporters of Daw Aung San Suu Kyi, General Secretary of the opposition NLD, and supporters of the government led to a number of people losing their lives. Daw Aung San Suu Kyi and 35 of her supporters were taken into custody. The incident caused international outrage and unanimous calls for the release of both her and her supporters, most of whom have now been released; on 9 November 2003, following recuperation at home from surgery, restrictions were reportedly lifted on Daw Aung San Suu Kyi, although she declined to accept her freedom until all her supporters were also released. As of mid-2006, she remains in protective custody at her home in Yangon. The Depiyin incident was widely interpreted in the international press as a premeditated attack on Daw Suu Kyi's cavalcade with the intention of disrupting her political activities in northern Myanmar, and is said to have been masterminded by the current Prime Minister, Lt. Gen. Soe Win, in his previous capacity as Secretary-1 of the SPDC. He had formerly been the regional commander in the Sagaing Division where the attack took place. Following the purge of General Khin Nyunt and his faction in October 2004, the SPDC announced that Daw Aung San Suu Kyi would not be released until at least November 2005. This has now been extended. Her position is considered to be more precarious now than during the stewardship of General Khin Nyunt.

3 A term usefully explored by Likhit Dhiravegin (1992) Demi-Democracy: The Evolution of the Thai Political System, Singapore: Times Academic Press.

4 On 27 November 2003, Myanmar denied US Treasury allegations that two private banks in Myanmar are engaged in 'money laundering', despite the country's new antimoney laundering legislation introduced in 2002. It is possible that this is an alternate means of transacting some of Myanmar's international trade and goes to demonstrate that such US sanctions undermine legitimate business activity. See Myanmar Information Sheet, 27 November 2003.

5 For an incisive discussion of China's motivations in joining the ASEAN Regional Forum, see Thammy Evans (2003) 'The PRC's Relationship with the ASEAN Regional Forum: Realpolitik, Regime Theory or a Continuation of the Sinic Zone of Influence System?' Modern Asian Studies, 37(3): 737-63. The author favours realistic 'sinic selfinterest' in the PRC's relations with regional states. This 'self-interest' encompasses being considered a responsible international citizen. It is also useful to note the assessment provided by Gerald Chan et al. (2000: 3 ) of the significance of the paradigm shift in China's relations with the region and the rest of the international community. China's leaders, they say, 'have become more receptive of modern norms in international relations but, at the same time, they still firmly uphold some traditional norms and values in foreign policy making, such as sovereignty, territorial integrity, and national interests'. On this point I wish to gratefully acknowledge the helpful discussions with my colleague, Dr Gerald Chan, Senior Fellow, Centre of International Studies, Cambridge University.

6 Two Indian energy majors, ONGC Videsh and GAIL India, hold joint equity stakes with Korea's Daewoo International and Korean Gas Company in the substantial gas reserves off Myanmar's Rakhine coast.

7 Myanmar's forces have frequently carried out operations against insurgent forces operating from India's north-east.

8 The Hindustan Times, 3 November 2003, noted India's official stance that Myanmar has a 'special place' in its Look East policy; the aim of the India-Myanmar Joint Trade Committee is to double bilateral trade turnover to USD 1 billion in the next 3 years with particular attention to joint projects in areas of information technology, telecommunications, hydrocarbons, engineering goods and pharmaceuticals. During former Foreign Minister U Win Aung's visit to India, a further USD 7 million loan from India to Myanmar was announced to establish a direct telephone link between the two countries. The Myanmar Times, 2 August 2004, reported that a letter of undertaking was signed in Yangon on July 27 between Myanmar Post and Telecommunications and the state-owned Telecommunications Consultants Limited of India. The project will 
include installing new telecommunications equipment in Yangon and Mandalay, as well as establishing an optical fibre cable connection between Tamu and Moreh on the Myanmar-India border. The present telephone connection between Myanmar and India routed through Britain, makes the tariff on phone calls between the two countries expensive. The direct telephone link between India and Myanmar is expected to promote trade, commerce, tourism and cultural relations.

9 Satu P. Limaye, Director of Research, Asia-Pacific Center for Security Studies, Hawaii, views the re-emergence of India in Asia in the mid-1990s as 'derived from the twin shocks of Soviet collapse and near financial default in the early 1990s. The importance of being Asian became stark. Enhanced ties with Asia were seen as a step to possible inclusion in the broader Asia Pacific community, including regional economic and political organizations. This web of inclusion was deemed vital if India was to avoid over-dependence upon any one power; compensate for the loss of political, economic, and military support from the ex-Soviet Union and Eastern Bloc countries; and escape isolation and marginalization in a new world order. Temporarily interrupted by the 1998 nuclear test.' India has since then enhanced its regional economic and political role. See India-East Relations: India's Latest Asian Incarnation, Comparative Connections, Pacific Forum CSIS, Honolulu, Hawaii, October 2000.

10 Agence France Presse, 3 November 2003 noted that since Myanmar maintains strong trading links with China and India, Western sanctions have minimal effect.

11 Gulshan Sachdeva (2000: 219-28) suggests that not only would further India-China cooperation be enhanced through such a growth quadrangle, but that it would also foster further regional economic integration.

12 The countries attending were: Australia, Germany, France, Italy, Austria, China, Japan, India, Singapore, Indonesia plus Thailand and Myanmar. Special envoy of the UN Secretary General, the Malaysian diplomat, Tun Razali Ismail, also participated.

13 See Bangkok Post, 21 September 2003, p. 3.

14 This trade is exclusive of Thailand's purchase of natural gas from Myanmar which, in 2002-3 was said to be AUD 875 million. See DFAT Burma Country Brief at www.dfat.gov.au

15 The latest round of US sanctions, confirmed again in 2005 and 2006, now closes this market to Myanmar exporters.

16 Although the majority of the Muslim population of both countries are peaceful, lawabiding citizens, both countries have a small minority of Islamic militants whom it is feared could easily be infiltrated by al-Qaeda agents. It is known that some Myanmar Muslims sought training in Pakistan with al-Qaeda before September 11, 2001. When Muslim-Buddhist community disturbances broke out in Upper Myanmar in late 2003, the government took firm action to ensure there was no widespread civil unrest. See Agence France Presse, 2 November 2003. Ordinary Muslims in Myanmar who are amongst the poorest, fear that the terrorist threat could be used to further suppress their community. In recognition of the sensitivity of this issue and how critical it is to national security, at the time of the cabinet reshuffle in early September 2003, the civilian Religious Affairs minister was replaced with a military man. Myanmar has keen memories of widespread communal violence between Buddhists and non-Buddhists during the $\mathrm{U} \mathrm{Nu}$ era of parliamentary democracy when the late Prime Minister was planning to make Buddhism the state religion. Myanmar is a secular state which has an official policy of religious toleration, although from time to time there continues to be reports of Buddhist-Christian conflict in Chin State and Buddhist-Muslim conflict in Rakhine State. It is noteworthy that there is also a Synagogue in Yangon.

17 In an important indicator of the new rapprochement between Thailand and Myanmar, the Thai Prime Minister would not allow even the incident of a Thai fishing trawler fired on by Myanmar authorities off Ranong, the day before the visit by the Thai Defence Minister, to impact on the cordial relations at the top. The incident was put down to imperfect communications at local level. 
18 The late General Ne Win was a close personal friend of ex-President Suharto and went to visit him as late as 1999 .

19 The 104 principles drafted previously as the basis for a new national constitution, and continued under the reconvened National Convention, ensure that the military in Myanmar will continue to have a controlling role in government.

20 BIMST-EC stands for Bangladesh, India, Myanmar, Sri Lanka and Thailand-Economic Cooperation.

21 BIMST-EC was launched in 1997 with the aim of promoting cooperation among its members in trade and investment, technology, transportation, communications, energy, tourism and fisheries.

22 See Agence France Presse, 2 November 2003. In 1991-2, some 20,000 Myanmar Muslims from Rakhine state (known as Rohingyas) fled repression. Some later returned under a United Nations High Commissioner for Refugees (UNHCR) initiative. The Myanmar government initially agreed to accept only 7,500 whose identities as Myanmar nationals had been verified. The UNHCR requested Bangladesh to integrate around 14,000 with local Bangladeshi, but Bangladesh did not agree to the request. Some further repatriations have taken place since 1997, but the process stalled over the refugees' unwillingness to return and the lengthy verification process on the Myanmar side.

23 See www.mofa.go.jp/region/asia-paci/myanmar/index.html. In September 2002, Japan also provided emergency humanitarian aid for the flood victims in Monywa at the request of the Myanmar government.

24 See www.AusAID.gov.au. Australia's International AusAID Development Cooperation Budget 2005-2006.htm and AusAID Country brief-Burma 2005.htm

25 Nossal (1994) writes from the perspective that economic sanctions are 'a blunt and crude tool of statecraft' by which vulnerable populations are 'doubly punished'. Nossal asserts: 'Not only do the people have to suffer the human rights abuses being visited on them by their own state apparatus; in addition, they have to suffer the economic deprivations visited on them by other states' (ibid. 266) in the mistaken notion that such deprivation will make these populations turn against their own governments and welcome those who are instrumental in causing deterioration in their economic well-being.

\section{Myanmar and the West: sanctions, engagement and security}

1 In the 1990s, the UN Security Council authorized 16 multilateral sanctions resolutions, compared to only two (Rhodesia and South Africa) previously. However, over one hundred unilateral sanctions were imposed in the twentieth century. Coercive unilateral economic sanctions/diplomacy by a superpower like the US can be effective against a smaller, weaker opponent which is dependent on it for trade, aid and investment (Mack and Khan 2000: 279, 281). However, in Myanmar's case, which now has no trade with the US following the Burma Freedom Act 2003 and renewed sanctions in mid-2004, the lack of economic dependency on the sender country and support from neighbouring countries with which it has substantial trade relations, enhance Myanmar's capacity to withstand the sanctions regime and serves to underline the essentially symbolic and rhetorical nature of US sanctions against the Myanmar military government. Myanmar's main trading partners, as discussed in Chapter 4, are all in the Asian region. If the US had more substantial economic investments in the country, it would have had more economic leverage. Moreover, even amongst anti-government groups there is now more open admission that Daw Aung San Suu Kyi's espousal of Western sanctions has not been to her advantage amongst the majority of Burmese/Myanmar citizens (see Aung Zaw, The Irrawaddy Magazine, 27 May 2005).

2 ASEM was formed in 1996 by seven ASEAN members Brunei, Indonesia, Malaysia, The Philippines, Singapore, Thailand and Vietnam - as well as Japan, South Korea and China and the then 15 members of the EU. The EU dropped its objections to approving 
ASEM membership for Myanmar at a meeting of its 25 foreign ministers in the Dutch city of Maastricht on 3 September 2004. At a two-day dialogue partner meeting on 6 September 2004 a draft declaration on closer Asia-Europe economic ties was prepared, to be submitted to the October 2004 summit for approval, according to the Vietnam News Agency report on 7 September 2004. Officials from Myanmar and the other new members of ASEM - Laos, Cambodia and the 10 new members of the EU attended the meeting (Myanmar Times, 13-19 September 2004).

3 See Bangkok Post, 1 November 2003. Hungary is among the 10 new countries to join the EU. The other nine are Estonia, Latvia, Lithuania, Poland, the Czech Republic, Slovakia, Slovenia, Malta and Cyprus.

4 This report states that Under the Burmese Freedom and Democracy Act of 2003, Public Law No. 108-61, the Secretary of State is required to provide a report 'identifying resources that will be necessary for the reconstruction of Burma, after the State Peace and Development Council (SPDC) is removed from power, including:

(A) the formation of democratic institutions;

(B) establishing the rule of law;

(C) establishing freedom of the press;

(D) providing for the successful reintegration of military officers and personnel into Burmese society; and providing health, educational and economic development.'

Since the SPDC is both unlikely to relinquish power in the near future, and unlikely to be 'removed from power' by the US or any other external agency, the resources to foster a vigorous civil society are destined to be forever withheld, at least from US sources.

5 Derek Tonkin, former UK Ambassador to Thailand 1986-9 and Chairman of the Beta Mekong Fund 1994-2000, noted that on 11 October 2004 EU Foreign Ministers stood poised to apply new sanctions against the SPDC, "while aiming to provide further humanitarian (but not development) assistance to the Burmese people (though to be frank only politicians see any difference)'. He commented,

However, the sanctions threatened by the EU seem unlikely to cause the junta to lose much sleep. Two of them, a visa ban from entering the EU on serving officers of Brigadier-General rank and above and their families, and a refusal by the EU to support financing for Burma from international institutions, already exist in practice, while the third proposed sanction, suspending loan and equity finance from EU companies for State enterprises, is hardly relevant since such direct foreign financing is not technically possible under current Burmese foreign investment legislation. The junta know all this perfectly well, so Rangoon (Yangon) seems bound to call the EU's bluff.... After 11 October, when the sanctions are imposed, EU Ministers are likely to call once more on their hapless officials to chase that elusive will o' the wisp, the targeted sanction, and come up with further recommendations for use in the next confrontational round. The merry-go-round of pin-prick sanctions and junta intransigence seems sure to continue... Meanwhile, Daw Aung San Suu Kyi is likely to remain under house arrest, the hand of the hard-liners in Rangoon has been strengthened, the UN General Assembly will later this year, and with the expected sole sponsorship of South Korea among Asian countries, pass its ritual annual Resolution condemning human rights abuses in Burma, and the UN Security Council will continue to fight shy of any discussion of mandatory sanctions.

(Burmese Perspectives, Guildford, 27 September 2004)

I am indebted to my colleague, Professor John Badgley, for making this communication available to me. 
6 Sanctions on Libya were lifted in 2004 when its leader, Muammar Gaddafi, paid the required compensation for Libyan complicity in the bombing of the Pan-Am airliner over Lockerbie, Scotland. The timing coincided with US energy security needs: the need to ensure access to Libya's oil supplies in face of continuing disruption of oil supplies from insurgency-ridden Iraq. At this stage, Myanmar's onshore oil reserves, now retained for exploitation only by government enterprises, are perceived to be insufficient to induce the US to wish to negotiate a less zero-sum game position.

7 The UK Foreign Office Minister for Trade, Ian Pearson, during the adjournment debate on Human Rights in Burma in the House of Commons on 15 June 2005, observed that the NLD had recently reiterated that it is not NLD policy to call for sanctions. The Minister said, 'We have to bear in mind the circumstances of the people in Burma. If the NLD is not explicitly calling on us to impose broad sanctions, we have to take account of that fact. We need to see whether there is something more effective that we can do, and I am happy to engage in debate and dialogue with people on that.' Commenting on the Minister's statement, Derek Tonkin, former UK Ambassador to Thailand, on 5 July 2005 commented,

The Minister's statement is welcome, because it may help to restore a measure of sanity to the debate on sanctions in the context of Burma. It should be noted that the Minister said that the NLD was reiterating its position on sanctions, not making a fresh statement nor advocating a new policy. Indeed, if NLD statements since 2000 are studied closely, it will be apparent that they have mellowed since the $1990 \mathrm{~s}$, in that they welcome humanitarian aid under appropriate conditions, and express understanding about why development aid and foreign investment may yet take time and why it may be premature to promote tourism. This nuanced policy has hitherto rarely, if ever, been reflected in ministerial statements in the UK, where fire and brimstone have generally been the order of the day. At the same time, it is clear that if the NLD were to push openly for broad sanctions against their country, the party would be dissolved on the grounds that they were advocating economic sabotage.

(Posted on Free Burma Coalition website, 6 July 2005, accessed 7 July 2005)

8 Mark Beeson (2003: 256) has highlighted the 'widespread unease about America's rather heavy-handed interventions in regional affairs' and has expressed the view that although most Asian nations still look to the system of bilateral American alliances in the region to maintain the balance of power between China, Japan, Korea and ASEAN, "if the "war on terror" goes badly, and if East Asia is generally seen to be damaged by events over which it has little control, then it is not inconceivable that a new, more inclusive calculus of the region's strategic interests may emerge'.

9 Posted on Free Burma Coalition website, 5 December 2004 (accessed 5 July 2005).

\section{Civil society and the political ecology of sustainable development: empowerment, opportunity and participation}

1 See U Kin Oung's meticulous study of the assassination of Bogyoke Aung San and six of his cabinet, plus two others: U Ohn Maung, 34 years old, Deputy Secretary of the Department of Transport and Communications who had come to deliver a report and Ko Htwe, 18, the bodyguard of U Abdul Razak, Councillor for Education and National Planning (a Muslim from Mandalay) who was shot four times by the retreating assassins, shows the ferocity with which the assassins gunned down the nine men in the Secretariat building that fateful morning. Aung San 'received 13 bullet wounds and died on the spot'; Deedok U Ba Choe, Councillor for Information, took five bullets, one in the brain, and died in Rangoon General Hospital that afternoon; Thakin Mya, 
Councillor for Finance was 'shot through the lungs and died on the spot'; U Abdul Razak received six wounds and 'died on the spot'; U Ba Win, Aung San's elder brother, received eight bullet wounds and 'died on the spot'; Sao Sam Htun, Sawbwa of the Shan State of Mong Pawn and Councillor for Frontier Areas received 'two wounds in the head and died in Rangoon General Hospital at noon' on 20 July 1947. The ringleader of the assassins, U Saw, and five of the gunmen were later tried and executed in May 1948; three others received 20 years' imprisonment; and one, Ba Nyunt, turned King's evidence and was sentenced to 10 years and 6 months 'rigorous imprisonment'. (Kin Oung 1996: 1-2). This fine study highlights the problematic nature of political governance in Burma/Myanmar, the endemic culture of political assassinations, factionalism, personal power politics and intrigue. Whilst U Kin Oung's painstaking research raises questions both about the complicity of certain British personnel and the role Ne Win may have played behind the scenes, it demonstrates above all how fragile the institutional framework for democratic governance was, and has been, in post-independence Burma/Myanmar.

2 See Donald Eugene Smith (1965), Religion and Politics in Burma, Princeton: Princeton University Press.

3 In recent communication concerning errors in the Tutu-Havel (2005) report on the results of the 1990 elections, Derek Tonkin points out that the NLD secured 59.87 per cent of valid votes cast, 52.44 per cent of all votes cast (valid and invalid) and 38.11 per cent of all eligible votes which could have been cast. The Tutu-Havel report used a report of a social anthropologist, John Dennis as its source. This report, 'A Review of National Social Policies: Myanmar', prepared for the Regional Environmental Technical Assistance 5771 Poverty Reduction \& Environmental Management in Remote Greater Mekong Subregion (GMS) Watersheds Project (Phase I) can be found at http://www.mekonginfo.org/mrc_en/doclib.nsf/0/AE24021D05C497DDC725682E003 722D4/\$FILE/FULLTEXT.html. Personal communication with Derek Tonkin, 6 October 2005.

4 Transparency International's Corruption Perceptions Index for 2003 ranked Myanmar at number 129 (out of 133 countries) and allocated it a score of 1.6 on the corruptions index wherein a score of 10 is 'very clean' (Finland was scored at 9.7) and a score of $\mathrm{O}$ is 'highly corrupt.' In this last grouping were also Paraguay (also scored 1.6), Haiti (1.5), Nigeria (1.4) and Bangladesh (1.3).

See http://www.transparency.org/cpi/2003/cpi2003.en.html (accessed 17 March 2005).

5 See James, H. (2005) Governance and Civil Society in Myanmar: Education, Health and Environment, London: RoutledgeCurzon, 112-52, for an in-depth discussion of land-use policies in Myanmar and their implications for effective poverty-alleviation programmes.

6 Commenting on the ethical issues involved in this series of regrettable decisions, Bruce Kent, writing in The Irrawaddy Magazine, 28 September 2005, 'Turbulence Ahead', states:

maybe it's time now to think about what all this achieves, when the rhetoric falls on deaf ears and the sanctions bounce off the armour in Rangoon. As one senior aid worker who often visits Burma says: 'The lobbyists in Washington are among those to blame for the poor state of humanitarian aid to Burma.'... UN agency workers in Burma were known to be unhappy about the straits in which humanitarian aid in Burma has been mired. A recent internal memo among senior UN officials had lamented humanitarian help for the country was a 'moral and ethical necessity' and an international obligation, according to a UN source... When the Global Fund announced its cut-off decision, it said 'the regime is making it impossible for us to work there.' That's easy to believe, because a paranoid junta so suspicious of any foreigner moving around the country has made it difficult for all UN agencies and NGOs to operate in Burma. When the relevant government committee, headed by the Health Ministry, responded to the Global Fund move, it 
admitted that new restrictions on movements by aid workers had been introduced, but said these were only temporary and should not lead to an irreversible cut-off by the Global Fund [italics mine].

Clearly, the temporary travel restrictions, for which there may well have been sound reasons given the upsurge in fighting in some of the border areas, were merely an excuse, compounded by the activities of lobbyists in Washington, for the US to withdraw its contributions to the Global Fund.

7 The official government view of Myanmar's timeline is set out in the 29 September 2005 statement by the Myanmar Ministry of Foreign Affairs as follows:

[T] he government announced a seven-step political programme in August 2003 which would definitely lead to the establishment of a modern, prosperous and democratic nation based on enduring institutions.

The first crucial step of this process was the successful reconvening of the national convention. The convention is [sic] attended by 1,088 delegates from eight categories. Sixty per cent of the delegates come from the national races. Representatives of 17 armed groups who have returned to the legal fold are also participating. The delegates are identifying basic principles for a new democratic state constitution by which to build a common future after decades of disunity and stagnation.

A constitution will be drafted with the principles agreed upon, and put to a national referendum. If approved, the constitution will pave the way for elections to the national and regional parliaments thereby ensuring a smooth transition to democracy. Myanmar is poised at the threshold of a new era.

The likely reaction of the US administration to the above processes may be found at http://www.state.gov/r/pa/prs/ps/2005/46836.htm

8 Dr Khin Zaw Win, a dental surgeon, worked in the health services of Myanmar and Malaysia. He served as consultant to UNICEF's Yangon office. While attending a master's course at the National University of Singapore, he returned briefly to Myanmar and was arrested in July 1994. Sentenced to 15 years in prison, he spent 11 years in jail, mainly at Myitkyina in the far north of the country.

9 Toe Zaw Latt, 'What Reconciliation?', Bangkok Post, 28 September 2005, at www.bangkokpost.com/news/28 Sept2005_news21ph

10 Kyaw Yin Hlaing points out that 'Although there were no formal civil society organizations in precolonial Burma, by the time the military took control... in 1962, there were a number of them. Thanks to Western education and the advent of print capitalism under the British, Burmese came to learn how formal associations could be formed and how people in other parts of the world, especially in the West, tried to achieve social and political objectives by forming associations. Burmese saw how Christian missionaries and European, Indian and Chinese business people formed religious, social and business associations soon after their arrival in Burma. Making use of this knowledge themselves, they began to form trade and student unions as well as religious, social welfare, business, community and native-place associations.... This is the chief reason why the military had to deal with so many civil society organizations in establishing the Burma Socialist Program Party (BSPP).... As a final move to curb the growth of civil society organizations, the government issued the National Solidarity Act of 1964 outlawing all political organizations and forbidding the formation of new political associations without government permission.' Although the socialist government narrowed legal space for non-political religious and business groups, some were condoned and continued to exist as long they were judged not to pose a political threat to the government. At other times, 'students, teachers, lawyers and writers created informal discussion groups and engaged in illegal political activities' (Kyaw Yin Hlaing 2004a: 392-5). This uneasy relationship continued in the post-1988 era. 'Community, professional, ethnic, native-place organizations have emerged...local 
environmental and social welfare organizations have done well as NGOs. They have engaged in several activities aimed at containing environmental degradation, alleviating poverty, and educating the public about HIV/AIDS ... social, business, and religious organizations have resisted the junta's attempt to co-opt them' (Kyaw Yin Hlaing 2004a: 406-7). In assessing the contribution and potential for civil society organizations to impact on social and political change, it is necessary to 'look beyond the legal space... set by the state' (ibid.: 414).

11 See Kyaw Yin Hlaing (2004: 409-10) for a succinct account of the internal power struggles and violence which rent the ABSDF in 1991; and his interesting comparison with the Free Burma Coalition which, based in the US was able to appropriate the networking capabilities and norms of its social and political envelope to achieve a measure of success in heightening awareness of Burma/Myanmar's socio-economic and political fabric in Western countries. Kyaw Yin Hlaing (2004: 396-8) also highlights the activities of CPB affiliated student groups in the 1988 civil disturbances, their suppression by the military government as a continuation of civil war type power paradigms which had been ongoing in the country since independence and the resort to again going underground by some of these elements. From his study of 42 such informal groups, he states that 12 confined their activities to political discussions, while eight took an active role in anti-government protests. He states, 'Members of CPB-connected study groups participated in both covert and overt anti-government activities' and most had been established for 15 to 20 years. Because of mutual lack of trust, the CPB-connected groups and the independent student groups found it difficult to work together; however, by co-opting the foreign media (VOA and BBC) they were able to disseminate news of their uprising (Kyaw Yin Hlaing 2004: 403).

12 Succinctly summarizing some of the key inaccuracies in the report, Derek Tonkin writes,

I feel that there are several inaccuracies and doubtful assessments in the report. Some of these are matters of detail easily corrected. On certain issues of substance, however, the authors of the report might perhaps have sought comments on the draft from a wider group of advisers. In this context, the following points seem relevant:

a. I doubt the wisdom of defining the action recommended as coming under 'Chapter VII of the UN Charter (Article 41).' Article 41 is concerned with the application of enforcement measures in the event of non-compliance with a Resolution made under Article 39, including in particular sanctions. The predetermining reference to Article 41 is likely to create a measure of confusion, since it places a possibly unwelcome and in any case unacceptable restriction on Security Council action in the event of non-compliance. It would have been better if the reference to Article 41 had been omitted.

b. The argument that the 1962 coup in Burma should be perceived 43 years later in 2005 as a current 'threat to the peace' is not compelling. It is in any case doubtful that the claim that 'the current government in Burma came to power in 1962 by overthrowing the elected government' (Page 51) correctly reflects historical fact. It is true that governments in Burma/Myanmar since 1962 have been dominated by the military, but in terms of constitutional law there have been two qualitative changes since 1962, the first in 1974 and the second in 1988. In December 1973 a new Constitution, designed to bring the post-coup period of unconstitutional rule to an end, was approved in a national referendum and came into effect in March 1974. Many Burmese would argue that the process was contrived, but nonetheless there was a process and the government changed from a Revolutionary Council to a National Assembly. The 1974 Constitution was abrogated in a military coup on 18 September 1988. Again, there are some who would argue that the coup was contrived, but even if this were the case, there was a qualitative constitutional change as power was taken from the National Assembly by the State 
Law and Order Restoration Council, which subsequently changed its name to the State Peace and Development Council.

c. The report claims that: 'In $1990 \ldots$ the National League for Democracy (NLD) became the democratically-elected government of Burma...'. Not even the NLD would claim this, since the National Assembly was never convened and no government was ever formed by the NLD as election victors. It would be correct to say that the NLD was prevented from forming a government. This resulted from a fundamental difference of view between the junta and the NLD about the process for the preparation and approval of a new Constitution and the subsequent transfer of power. This thoroughly unsatisfactory situation, for which the junta was overwhelmingly responsible for failing to hold consultations with political parties prior to the elections in May 1990, was recognised by Daw Aung San Suu Kyi herself prior to her detention in July 1989. (See her Freedom from Fear Chapter 17 - Interview with Dominic Faulder of AsiaWeek July 1989.)

d. The sections on narcotics and HIV/Aids have proved to be highly controversial, with UN agencies in Burma/Myanmar contesting on technical grounds some of the basic assertions in the report, for example (Page 57) that 'the primary strain of the HIV virus present throughout Southeast Asia has conclusively [my emphasis - DT] been shown to have originated in Burma, where it followed opium and heroin trafficking routes out of the country' when the evidence for this was publicly contested by UN agencies in Burma/Myanmar even before the report was published. There are continuing exchanges on these issues.

e. The assertion on Page 13 that 'the government prohibits full foreign ownership of companies operating in Burma' is incorrect, since this is permitted under Article 5 of the Foreign Investment Law 1988. Two such 100\% owned foreign companies were incorrectly listed in EU legislation in 2004 as 'Joint Ventures' with a military conglomerate. They were Myanmar Hotels and Cruises Ltd (a UK owned company) and Myanmar Hwa Fu International Ltd (a Hong Kong owned company), and were later removed from the EU list.

f. There are numerous omissions in the report which detract from its objectivity. There is no account of previous unsuccessful attempts, particularly during the last two years, to raise the situation of Burma/Myanmar in the Security Council. There are no references to statements in the UK Parliament that there is no consensus for such action in the Security Council. The extent of Chinese, Indian and Japanese interests in Burma/Myanmar on Pages 38 and 39 is too briefly examined and seriously understated. There is no consideration of the likely attitude of Russia, which has significant interests in Burma/Myanmar, to the recommendation for Chapter VII action. There is no assessment of the very unfortunate consequences if China and/or Russia were to veto a Resolution forced under congressional pressure on to the Security Council's agenda.

I thank Derek Tonkin for permission to quote at length from his article which may now be found on the Free Burma Coalition website at www.freeburmacoalition.org. A summary of further historical inaccuracies in the report is available at http//www. freeburmacoalition.org/derektonkinonhaveltutureport.htm

\section{Conclusion: towards a more civil society?}

1 The full report and recommendations can be found at http://www.ibiblio.org/obl/ docs3/GA2005-SRM-rep-en.pdf 
2 The government of Myanmar's seven-point 'road map' to democracy announced in August 2003, is as follows:

(a) The reconvening of the National Convention, which had been adjourned since 1996;

(b) After the successful holding of the National Convention, step-by-step implementation of the process necessary for the emergence of a genuine and disciplined democratic State;

(c) The drafting of a new constitution in accordance with basic principles and detailed basic principles laid down by the National Convention;

(d) The adoption of the constitution through national referendum;

(e) The holding of free and fair elections for legislative bodies (Hluttaws) according to the new constitution;

(f) The convening of legislative bodies attended by legislative body members in accordance with the new constitution;

(g) The building of a modern, developed and democratic nation by the State leaders elected by the legislative bodies, the Government and other central organs.

As Professor Pinheiro's report makes clear (para. 18) the new Prime Minister, Lt. Gen. Soe Win, expressed the continued commitment of the government of Myanmar to implementation of the seven-point road map. Furthermore, at a press conference on 1 February 2005, the new Minister for Information stated that 'the detailed basic principles for sharing legislative power which had been discussed during the last phase of the National Convention would be approved in its next phase, starting on 17 February 2005. He added that discussion and coordination would also take place for formulating detailed basic principles for sharing executive and judicial powers.' Professor Pinheiro (paras 18-22) provides the following summary of the background, composition, focus and issues surrounding the National Convention:

First convened in 1993, the National Convention had the task of laying down the basic principles for the drafting of a firm and stable constitution (State Law and Order Restoration Committee Declaration 11/92, 1992). Comprising delegates chosen by the Government, it met sporadically for three years, having been instructed by the Government to develop language based on the six objectives that had been drawn up three months earlier. The objectives upon which the future constitution was to be based were: the maintenance of the integrity of the Union; the maintenance of national solidarity; the perpetuation of sovereignty; the flourishing of a genuine multiparty democratic system; the development of the eternal principles of justice, liberty and equality in the State; and the participation of the Tatmadaw (army) in the national political leadership role of the State. Included in the principles laid down was the assurance of a leading role for the army in any future Government, including in the choice of the Head of State; the allocation of 25 per cent of the seats in the legislature to the military; the proviso that the Tatmadaw be free to administer itself, without any parliamentary supervision; and the appointment of members of the military to the positions of Minister of Defence, Minister for Security/Home Affairs and Minister for Border Affairs. The six objectives, together with the 104 principles and subsequent seven detailed basic principles (regarding the judiciary, the executive, the legislature, self administered areas, the State, the State structure and the Head of State), dictate the parameters and language and provide a skeleton structure for the future constitution. Throughout the various sessions of the National Convention, the Government made it clear to the delegates that participation in the Convention should entail the acceptance of the fact that the above-mentioned principles governed the constitution-drafting process. 
The National Convention has now been in existence for over 12 years. By 1996, the National League for Democracy (NLD), the winners of the 1990 election, had boycotted some of the Convention sessions, citing the undemocratic nature of its procedures and the human rights abuses perpetrated during its proceedings ... Adjourned in May 1996, the National Convention remained suspended until 2004, when it was reconvened for an eight-week period from 17 May to 9 July 2004 and resumed work on the detailed basic principles. The reconvening of the National Convention represented 'the first step of the seven point road map for national reconciliation and democratic transition', according to the then Prime Minister, General Khin Nyunt... The NLD ... did not join the reconvened National Convention. NLD offices remain closed and sealed by the Government, with the sole exception of the Yangon Office. The General-Secretary of NLD, Daw Aung San Suu Kyi, and the Vice-Chairman, U Tin Oo, remain under house arrest, with no date given by the Government for their release. NLD members continue to suffer intimidation and arrest by Government forces. Other political party activists, including Members of Parliament-elect, remain in detention for their political activities.

3 Underlining the importance of India and China to the world economy, Australian Treasurer, Peter Costello, in an extraordinary statement at the Group of 20 meeting of finance leaders and central bank chiefs outside Beijing, 15-16 October 2005, labelled the IMF and the World Bank as 'outdated institutions from a bygone era with questionable relevance to a world in which China and India are emerging as economic powers' (The Australian, 17 October 2005, p. 27). The Treasurer's stance is said to be part of a concerted strategy designed to break down US and European dominance of the IMF and the World Bank and to give emerging Asian economies a greater say in running the world economy. 


\section{Bibliography}

Acharya, A. (1995) Human Rights in Southeast Asia: Dilemmas for Foreign Policy, Toronto: University of Toronto and York University Joint Centre for Asia Pacific Studies, East Asia Policy Papers No. 11.

- (1998) 'Collective Identity and Conflict Management in Southeast Asia', in Adler, E. and Barnett, M. (eds) Security Communities, Cambridge, MA: Cambridge University Press, pp. 198-227.

_ (1999) Engagement or Estrangement: India and the Asia Pacific Region, Toronto: University of Toronto and York University Joint Centre for Asia Pacific Studies, East Asia Policy Papers No. 19.

(2002) Regionalism and Multilateralism: Essays on Cooperative Security in the Asia-Pacific, Singapore: Times Academic Press.

(2002a) 'Human Security: What Kind for the Asia-Pacific?', in Dickens, D. (ed.) The Human Face of Security: Asia-Pacific Perspectives, Canberra: ANU-Strategic and Defence Studies Centre in association with the Centre for Strategic Studies, Victoria University, Wellington on behalf of The Council for Security Cooperation in the Asia-Pacific, pp. 5-17.

_ (2004) 'Will Asia's Past be its Future?', International Security, 28(3): 149-64.

Adler, E. and Barnett, M. (eds) (1998) Security Communities, Cambridge, MA: Cambridge University Press.

Agence France Presse, 2 November 2003.

Agence France Presse, 3 November 2003.

Agence France Presse, 17 April 2004.

Agence France Presse, 1 June 2005.

Ahmedullah, M. (2003) 'Burma: Not-So-Selective Sanctions', Bulletin of the Atomic Scientists, November/December 2003, pp. 12-14.

Alagappa, M. (1995) 'Regionalism and Security: A Conceptual Investigation', in Mack, A. and Ravenhill, J. (eds) Pacific Cooperation: Building Economic and Security Regimes in the Asia-Pacific Region, Boulder, CO: Westview Press, pp. 152-79.

- (ed.) (2001) Coercion and Governance: The Declining Political Role of the Military in Asia, Stanford, CA: Stanford University Press.

- (ed.) (2004) Civil Society and Political Change in Asia: Expanding and Contracting Democratic Space, Stanford, CA: Stanford University Press.

Anderson, J. (1876) Mandalay to Momien: A Narrative of the Two Expeditions to Western China of 1868 and 1875, London: Macmillan and Co.

Archer Report, Journey in the Me-kong Valley, 1892 (Scott MS Cambridge University Library UL.1.9). 
Asian Development Bank (ADB) (2002) Country Assistance Plan (2000-2002), Manila: Asian Development Bank.

Asia Times, 17 March 2005.

Aung San Suu Kyi (1991) Freedom from Fear and Other Writings, Harmondsworth: Penguin. Foreword by Vaclav Havel. Edited and with introduction by Michael Aris.

Aung-Thwin, M. (2002) 'Parochial Universalism, Democracy Jihad and the Orientalist Image of Burma: The New Evangelism', Pacific Affairs, 74(4): 483-505.

The Australian, 18 November 2003.

The Australian, 7 January 2005.

The Australian, 5 April 2005.

The Australian, 17 October 2005.

Australian Department of Foreign Affairs and Trade (DFAT) (2003) Burma Country Brief, www.dfat.gov.au

Badgley, J. (ed.) (2004) Reconciling Burma/Myanmar: Essays on U.S. Relations with Burma, vol. 15, no. 1, Seattle, WA: National Bureau of Asian Research.

— (2004a) 'Reconciling Myanmar/Burma: What is the US-EU Interest?', unpublished conference paper, 26 November 2004, Paving the way for Democracy in Burma, Malmo, Sweden.

Baginda, A. R. and Bergin, A. (1998) Asia Pacific Security Dilemma: Multilateral Relations Amidst Political, Social and Economic Changes, London: ASEAN Academic Press.

Bailes, A. J. K. (ed.) (2003) SIPRI Yearbook 2003, New York: Oxford University Press.

Bajpai, K. and Mattoo, A. (eds) (2000) The Peacock and the Dragon: India-China Relations in the 21st Century, New Delhi: Har-Anand Publications.

Balmaks, A. V. (1999) The Utility of Non-official Security Dialogue in the Asia-Pacific in the Post Cold War Era, Canberra: Australian Defence Studies Centre, Working Paper No. 52.

Bangkok Post, 21 September 2003.

Bangkok Post, 18 April 2004.

Bangkok Post, 7 July 2005.

Bangkok Post, 28 September 2005.

Bangkok Post, 12 October 2005.

Barker, R. (2001) Legitimating Identities: The Self-Presentation of Rulers and Subjects, Cambridge: Cambridge University Press.

Beeson, M. (2003) 'ASEAN Plus Three and the Rise of Reactionary Regionalism', Contemporary Southeast Asia, 25(2): 251-68.

Benedict, C. (1996) Bubonic Plague in Nineteenth-Century China, Stanford, CA: Stanford University Press.

Bhaskar, U. (2000) 'Myanmar in the Strategic Calculus of India and China', in Bajpai, K. and Mattoo, A. (eds) The Peacock and the Dragon: India-China Relations in the 21st Century, New Delhi: Har-Anand Publications, pp. 349-60.

Blake, R. (1999) Jardine Matheson: Traders of the Far East, London: Weidenfeld and Nicolson.

Blondel, Y. I. (2004) Power of Symbolic Power: An Application of O'Neill's Game of Honour to Asymmetric Internal Conflict, Uppsala, Sweden: Department of Peace and Conflict Research, Uppsala University.

Blum, W. (2001, 2nd edn 2003) Rogue State: A Guide to the World's only Superpower, London: Zed Books.

Boucard, A. and Boucard, L. (1988; rev. edn 1992) Burma's Golden Triangle: On the trail of the Opium Warlords, Bangkok: Asia Books. (First English edn 1988; first French edn 1985.) 
Bracken, P. (2001) 'Technology and the Military Face of Asian Security', in Simon, S. W. (ed.) The Many Faces of Asian Security, Lanham, MD: Rowan and Littlefield Publishers, pp. 71-87.

Brook, T. and Wakabayashi, B. T. (eds) (2000) Opium Regimes: China, Britain and Japan, 1839-1952, Berkeley, CA: University of California Press.

Broomhall, M. (1930) Hudson Taylor: The Man who Believed God, London: China Inland Mission.

Brunnee, J. and Toope, S. J. (2004) 'Canada and the Use of Force: Reclaiming Human Security', International Journal, 59(2): 247-60.

Buckley, R. (2005) 'A Nomination that's Likely to be Deeply Divisive', The Canberra Times, 21 March 2005, p. 13.

Bull, H. (1977, 3rd edn 2002) The Anarchical Society: A Study of Order in World Politics, Houndmills, Basingstoke: Palgrave.

Caballero-Anthony, M. (2001) 'Human Security and Comprehensive Security in ASEAN', in Thiparat, P. (ed.) The Quest for Human Security: The Next Phase of ASEAN? Bangkok: Institute for Strategic and International Studies, Chulalongkorn University, pp. 21-52.

Callahan, M. (2003) Making Enemies: War and State Building in Burma, Ithaca, NY and London: Cornell University Press.

The Canberra Times, 'Darfur Crisis a Critical Test for UN, Says Amnesty', 4 September 2004, p. 18.

The Canberra Times, 14 October 2005.

Chambers, S. and Kymlicka, W. (eds) (2002) Alternative Conceptions of Civil Society, Princeton, NJ: Princeton University Press.

Chan, C. and Drury, A. C. (2000) Sanctions as Economic Statecraft: Theory and Practice, Houndmills, Basingstoke and New York: Macmillan Press and St Martin's Press.

Chan, G. (1999) Chinese Perspectives on International Relations: A Framework for Analysis, Basingstoke and New York: Macmillan Press Ltd and St Martin's Press Inc.

Chan, G., Weixing, H. and Zha, D. (eds) (2000) China's International Relations in the 21st Century: Dynamics of Paradigm Shifts, Lanham MD, New York and Oxford: University Press of America, Inc.

Cheater, A. (ed.) (1999) The Anthropology of Power: Empowerment and Disempowerment in Changing Structures, London: Routledge.

Chew, L. K. 'Asean and EU Thrash Out Myanmar Problem', Straits Times, 4 July 2004.

Chipman, J. (1997) 'The New Regionalism: Avoiding Strategic Hubris', in Roy, D. (ed.) The New Security Agenda in the Asia-Pacific Region, Basingstoke and New York: Macmillan and St Martin's Press Inc., pp. 20-30.

Chutintaranond, S. (1995) On Both Sides of the Tenasserim Range: A History of Siamese-Burmese Relations, Bangkok: Institute of Asian Studies, Monograph No. 50, Chulalongkorn University Press.

Chutintaranond, S. and U-Sha, K. (eds) (2001) From Fact to Fiction: History of Thailand-Myanmar Relations in Cultural Context, Bangkok: Institute of Asian Studies, Chulalongkorn University Press.

Clark, A. (1999) 'Myanmar's Present Development and Future Options', Asian Survey, 39(5): 772-91.

Clark, I. (1989) Hierarchy of States: Reform and Resistance in the International Order, Cambridge: Cambridge University Press.

- (2003) 'Legitimacy and Global Order', Review of International Studies, 29: 75-95. 
Cohen, J. L. and Arato, A. (eds) (1992) Civil Society and Political Theory, Cambridge, MA: MIT press.

Collier, P. and Hoeffler, A. (2000) Greed and Grievance in Civil War, New York: World Bank Policy Research Working Paper No. 2355.

Collignon, S. (2001) 'Human Rights and the Economy in Burma', in Taylor, R. H. (ed.) Burma: Political Economy under Military Rule, London: Hurst, pp. 70-108.

Colquhoun, A. (1883) Across Chryse: Being the Narrative of a Journey of Exploration through the South China Border Lands from Canton to Mandalay, 2 vols, London: Sampson Low, Manston, Searle and Rivington.

Cooper, J. F. (1838, rpt. 1969) The American Democrat, Harmondsworth: Penguin.

Davenport-Hines, D. (2001) The Pursuit of Oblivion: A Global History of Narcotics 1500-2000, London: Weidenfeld and Nicolson.

De Quincey, T. (1853, rpt. 1960) The Confessions of an English Opium-Eater; Introduction by John E. Jordan, London: Dent; New York: Dutton.

Devitt, D. B. and Acharya, A. (1996) Cooperative Security and Developmental Assistance: The Relationship between Security and Development with Reference to Eastern Asia, Toronto: University of Toronto and York University, Joint Centre for Asia Pacific Studies, East Asia Policy Papers No. 16.

Dhiravegin, L. (1992) Demi-Democracy: The Evolution of the Thai Political System, Singapore: Times Academic Press.

Dickens, D. (2002) 'Introduction', in Dickens, D. (ed.) The Human Face of Security: Asia-Pacific Perspectives, Canberra: ANU-Strategic and Defence Studies Centre in association with the Centre for Strategic Studies, Victoria University of Wellington on behalf of The Council for Security Cooperation in the Asia-Pacific, pp. 1-4.

Donnelly, J. (1989) Universal Human Rights in Theory and Practice, Ithaca, NY: Cornell University Press.

- (1993) International Human Rights, Boulder, CO: Westview Press.

Doornbos, M. (2003) “ “Good Governance”: The Metamorphosis of a Policy Metaphor', Journal of International Affairs, 57(1): 3-17.

Downs, J. M. (1997) The Golden Ghetto: The American Commercial Community at Canton and the Shaping of American China Policy, 1784-1844, Bethlehem: Lehigh University Press; London: Associated University Press.

Drezner, D. W. (1999) The Sanctions Paradox: Economic Statecraft and International Relations, Cambridge: Cambridge University Press.

- (2000) 'Bargaining, Enforcement, and Multilateral Sanctions: When is Cooperation Counterproductive?' International Organization, 54(1): 73-102.

Duncan, C. R. (2004) Civilizing the Margins: Southeast Asian Government Policies for the Development of Minorities, Ithaca, NY and London: Cornell University Press.

Dunne, T., Hill, C. and Hanson, M. (2001) 'The New Humanitarian Interventionism', in Hanson, M. and Tow, W. (eds) International Relations in the New Century: An Australian Perspective, Melbourne: Oxford University Press, pp. 93-116.

Dupont, A. (2001) East Asia Imperilled, Cambridge: Cambridge University Press.

The Economist, 21 July 2005.

Edwards, P. and Goldsworthy, D. (eds) (2003) Facing North: A Century of Australian Engagement with Asia: Vol. 2: 1970s to 2000, Australian Department of Foreign Affairs Trade, Carlton: Melbourne University Press.

Ehrenberg, J. (1999) Civil Society: The Critical History of an Idea, New York and London: New York University Press.

Enriquez, C. M. (1923) A Burmese Arcady, London: Seeley, Service and Co Ltd. 
Etzioni, A. (2004) 'A Self-restrained Approach to Nation-Building by Foreign Powers', International Affairs, 80(1): 1-17.

Evans, T. (2003) 'The PRC's Relationship with the ASEAN Regional Forum: Realpolitik, Regime Theory or a Continuation of the Sinic Zone of Influence System?' Modern Asian Studies, 37(3): 737-63.

Falk, R. (2004) 'Human Rights', Foreign Policy, March/April 2004, pp. 18-26.

Farooqui, A. (1998) Smuggling as Subversion: Colonialism, Indian Merchants and the Politics of Opium, New Delhi: New Age International (P) Ltd. Publishers.

Ferguson, R. J. (2004) 'Policy Prospects for Participant Regional "Development", Contemporary Southeast Asia, 26(3): 393-415.

Fisher, J. (1993) The Road from Rio: Sustainable Development and the Nongovernmental Movement in the Third World, West Hartford, CT: Kumarian Press.

— (1998) Nongovernments: NGOs and the Political Development of the Third World, West Hartford, CT: Kumarian Press.

- (2003) 'Local and Global: International Governance and Civil Society', Journal of International Affairs, 57(1): 19-39.

Frost, M. (1996) Ethics in International Relations: A Constitutive Theory, Cambridge: Cambridge University Press.

Furnivall, J. S. (1948) Colonial Policy and Practice: A Comparative Study of Burma and Netherlands India, Cambridge: Cambridge University Press.

— (1958) The Governance of Modern Burma, New York: Institute of Pacific Relations. (1983) 'The Fashioning of Leviathan: The Beginnings of British Rule in Burma', Journal of the Burma Research Society, 29(1): 3-137.

Gellner, E. (1994) Conditions of Liberty: Civil Society and its Rivals, London: Hamish Hamilton.

Ghosh, P. (2000) Brave Men of the Hills: Resistance and Rebellion in Burma, 1825-1932, Honolulu, HI: University of Hawaii Press.

Gibson, R. and Haseman, J. (2003) 'Prospects for Controlling Narcotics Production and Trafficking in Myanmar', Contemporary Southeast Asia, 25(1): 1-19.

Gill, W. (1883) The River of Golden Sand: A Journey through China and Eastern Tibet to Burmah, London: John Murray.

Gledhill, J. (1994, 2nd edn 2000) Power and its Disguises: Anthropological Perspectives on Politics, London: Pluto Press.

Goh, T. S. (1997) Asean and the Post Cold War Regional Order: Beyond Zopfan to the $A R F$, Canberra: Australian Defence Studies Centre Working Paper, No. 48.

Goldmann, K., Hannerz, U. and Westin, C. (eds) (2000) Nationalism and Internationalism in the Post-Cold War Era, London and New York: Routledge.

Goldsworthy, D. (2003) 'East Timor', in Edwards, P. and Goldsworthy, D. (eds) Facing North: A Century of Australian Engagement with Asia: Vol. 2: 1970s to 2000, Australian Department of Foreign Affairs Trade, Carlton: Melbourne University Press, pp. 216-57.

Gordon, C. (1875) Our Trip to Burmah: With Notes on that Country, London: Bailliere, Tindall and Cox.

Gove, M. (2004) 'Ideology, not Tribal Hate, Spurred Massacre', The Australian, 8 September 2004, p. 12.

Haacke, J. (2003) ASEAN's Diplomatic and Security Culture: Origins, Development and Prospects, London and New York: RoutledgeCurzon.

Haines, C. R. (1884) A Vindication of England's Policy with Regard to the Opium Trade, London: WH Allen and Co.

Hall, J. A. (ed.) (1995) Civil Society, Theory, History, Comparison, Cambridge: Polity Press. 


\section{Bibliography}

Hann, C. and Dunn, E. (eds) (1996) Civil Society: Challenging Western Models, London and New York: Routledge.

Hanson, M. and Tow, W. (eds) (2001) International Relations in the New Century: An Australian Perspective, Melbourne: Oxford University Press.

Harris, J. (ed.) (2003) Civil Society in British History, Oxford: Oxford University Press.

Harris, S. and Mack, A. (eds) (1997) Asia-Pacific Security: The Economics-Politics Nexus, St Leonards: Allen and Unwin.

Haseman, J. (1997) Burma's Myriad National Security Challenges: The Historical Background and Contemporary Events, Canberra: Australian Defence Studies Centre, Working Paper No. 50.

Havel, V. and Tutu, D. (2005) Threat to the Peace: A call for the U.N. Security Council to Act in Burma, report commissioned for the UN, prepared by DLA Piper Rudnick Gray Cary, Lawyers.

Hawthorn, G. (1976, 2nd edn 1987) Enlightenment and Despair: A History of Social Theory, Cambridge: Cambridge University Press.

Hill, J. S. (1884) The Indo-Chinese Opium Trade: Considered in Relation to its History, Morality, and Expediency and its Influence on Christian Missions, London: Henry Froude.

The Hindustan Times, 3 November 2003.

Hla Min (2001, rev edn 2004) Political Situation of the Union of Myanmar and its Role in the Region, Yangon: Ministry of Defence.

Hurrell, A. and Woods, N. (1999) Inequality, Globalization and World Politics, Oxford: Oxford University Press.

International Commission on Intervention and State Sovereignty (2001) The Responsibility to Protect, Ottawa: International Development Research Centre.

The Irrawaddy Magazine, 13 May 2005.

The Irrawaddy Magazine, 18 August 2005.

The Irrawaddy Magazine, 28 September 2005.

Jackson, R. H. (1990) Quasi-States: Sovereignty, International Relations, and the Third World, Cambridge: Cambridge University Press.

James, H. (2000) 'The Fall of Ayutthaya: A Re-assessment', Journal of Burma Studies, 5: $75-108$.

- (2003) 'Cooperation and Community Empowerment in Myanmar in the Context of Myanmar Agenda 21', Journal of Asian Pacific Economic Literature, 17(1): 1-21.

— (2004) 'King Solomon's Judgment', in Badgley, J. (ed.) Reconciling Burma/ Myanmar: Essays on U.S. Relations with Burma, vol. 15, no. 1, Seattle: National Bureau of Asian Research, pp. 55-66.

(2004a) 'Myanmar's International Relations Strategy: The Search for Security', Contemporary Southeast Asia, 26(3): 530-53.

_ (2004b) 'Dancing or Stricken Peacock? Than Shwe, Suu Kyi and the Politics of Institutional Change in Myanmar', Faits-et-Projets, Paris, August 2004.

_ (2004c) 'General Council of Burmese Associations (GCBA) (1920)', in Keat Gin Ooi (ed.) Southeast Asia an Historical Encyclopedia: From Angkor Wat to East Timor, 3 vols, Santa Barbara, Denver and Oxford: ABC-CLIO, vol. 1, pp. 540-1.

(2005) Governance and Civil Society in Myanmar: Education, Health and Environment, London: RoutledgeCurzon.

Jardine-Matheson MS Collection, University of Cambridge Library, MS J-MC9/1-10 Private Letter Books, Hong Kong to India.

Jennings, J. M. (1997) The Opium Empire: Japanese Imperialism and Drug Trafficking in Asia, 1895-1945, Westport, CT: Praeger. 
Jing, C., Kaempfer, W. H. and Lowenberg, A. D. (2003) 'Instrument Choice and the Effectiveness of International Sanctions: A Simultaneous Equations Approach', Journal of Peace Research, 40(5): 519-35.

Johnson, C. (2000) Blowback: The Costs and Consequences of American Empire, Boston: Little Brown and Company.

Jussila, H., Majoral, R. and Delgado-Cravidao, F. (eds) (2001) Globalization and Marginality in Geographical Space Political, Economic and Social Issues of Development in the New Millennium, Ashgate: Aldershot.

Kaldor, M. (1999) New and Old Wars: Organized Violence in a Global Era, Cambridge: Polity Press.

_ (ed.) (2000) Global Insecurity Restructuring the Global Military Sector, Volume III, London and New York: Pinter.

_ (2003) Global Civil Society: An Answer to War, Cambridge: Polity Press.

Kato, K. (2004) Peace and Stability in Myanmar from another Angle: Poverty Alleviation and Social Development among Ethnic Minorities, Tokyo: Japan Institute of International Affairs.

Katsumata, H. (2004) "Why is ASEAN Diplomacy Changing? From "Non-Interference" to "Open and Frank Discussions"', Asian Survey, 44(2): 237-54.

Keal, P. (2003) European Conquest and the Rights of Indigenous Peoples, Cambridge: Cambridge University Press.

Keck, M. E. and Sikkink, K. (1998), Activists beyond Borders: Advocacy Networks in International Politics, Ithaca, NY and London: Cornell University Press.

Kenny, M. (2003) 'Global Civil Society: A Liberal-Republican Argument', Review of International Studies, 29: 119-43.

Keswick, M. (1982) The Thistle and the Jade, Hong Kong: Octopus Books.

Kim, W. (2002) 'Human Security Concerns in Global Politics', in Dickens, D. (ed.) The Human Face of Security: Asia-Pacific Perspectives, Canberra: ANU-Strategic and Defence Studies Centre in association with the Centre for Strategic Studies, Victoria University, Wellington on behalf of The Council for Security Cooperation in the Asia-Pacific, pp. 44-52.

Kin Oung (1993, 2nd edn 1996) Who Killed Aung San? Bangkok: White Lotus.

Koenig, W. (1990) The Burmese Polity 1752-1819, Ann Arbor: University of Michigan Press.

Kuik, Cheng-Chwee (2005) 'Multilateralism in China's ASEAN Policy: Its Evolution, Characteristics and Aspiration', Contemporary Southeast Asia, 27(1): 102-22.

Kyaw Yin Hlaing (2002) 'The Politics of Government-Business Relations in Myanmar', Asian Journal of Political Science, 10(1): 77-104.

(2004) 'Myanmar in 2003: Frustration and Despair?' Asian Survey, 44(1): 87-92.

(2004a) 'Burma: Civil Society Skirting Regime Rules', in Alagappa, M. (ed.) Civil

Society and Political Change in Asia: Expanding and Contracting Democratic Space, Stanford: Stanford University Press, pp. 389-418.

Laitin, D. (1996) 'A Formal Model of Marginality and Security', in Nolutshungu, S. C. (ed.) Margins of Insecurity: Minorities and International Security, Rochester, NY: University of Rochester Press, pp.37-58.

Lambrecht, C. W. (2004) 'Oxymoronic Development: The Military as Benefactor in the Border Regions of Burma', in Duncan, C. R. (ed.) Civilizing the Margins: Southeast Asian Government Policies for the Development of Minorities, Ithaca, NY and London: Cornell University Press, pp. 150-81.

Land, J.-E. and Ersson, S. (2000) The New Institutional Politics: Performance and Outcomes, London and New York: Routledge. 


\section{Bibliography}

Le Fevour, E. (1968) Western Enterprise in Late Ch'ing China: A Selective Survey of Jardine, Matheson and Company's Operations 1842-1895, Cambridge, MA: Harvard University Press.

Leifer, M. (1996) The ASEAN Regional Forum, Adelphi Paper 302, IISS, London: Oxford University Press.

— (1998) The ASEAN Regional Forum: A Model for Cooperative Security in the Middle East, Canberra: ANU Department of International Relations, Working Paper No. 1998/1.

Lektzian, D. (2003) 'The Economic Peace between Democracies: Economic Sanctions and Domestic Institutions', Journal of Peace Research, 40(6): 641-60.

Lieberman, V. B. (1984) Burmese Administrative Cycles: Anarchy and Conquest 1580-1760, Princeton, NJ: Princeton University Press.

Limaye, S. P. (October 2000) 'India-East Relations: India's Latest Asian Incarnation', Comparative Connections, Honolulu, HI: Pacific Forum Centre of Strategic International Studies.

Lintner, B. (1990) The Rise and Fall of the Communist Party of Burma, Ithaca, NY: Cornell University Press.

- (1990a) Land of Jade, Bangkok: White Lotus.

_ (1994) Burma in Revolt: Opium and Insurgency Since 1948, Boulder, CO: Westview Press and Bangkok: White Lotus.

- (2000) 'Drugs and Economic Growth in Burma Today', in Pedersen, M., Rudland, E. and May, R. J. (eds) Burma/Myanmar: Strong Regime, Weak State? Adelaide: Crawford House Publishing, pp. 164-94.

Lodwick, K. (1996) Crusaders against Opium: Protestant Missionaries in China, 18741917, Lexington, KY: University of Kentucky Press.

Lyons, G. M. and Mayall, J. (eds) (2003) International Human Rights in the 21st Century: Protecting the Rights of Groups, Lanham, MD, Boulder, CO, New York, Oxford: Rowman and Littlefield Publishers, Inc.

McCoy, A. (1991, 3rd rev. edn 2003) The Politics of Heroin in Southeast Asia: CIA Complicity in the Global Drug Trade, Brooklyn, NY: Lawrence Hill Books.

McCullers, C. (1948, rpt. 1965) The Member of the Wedding, New York: Houghton Mifflin Co., Boston and Time Life Books.

McGillivray, F. and Stam, A. C. (2004) 'Political Institutions, Coercive Diplomacy, and the Duration of Economic Sanctions', Journal of Conflict Resolution, 48(2): 154-72.

Mack, A. and Khan, A. (2000) 'The Efficacy of UN Sanctions', Security Dialogue, 31(3): 279-92.

Mack, A. and Ravenhill, J. (eds) (1995) Pacific Cooperation: Building Economic and Security Regimes in the Asia-Pacific Region, Boulder, CO: Westview Press.

McRae, R. and Hubert, D. (eds) (2001) Human Security and the New Diplomacy: Protecting People, Promoting Peace, Montreal, Kingston and London: McGill-Queen's University Press.

Malik, M. (2000) 'Burma's Role in Regional Security', in Pederson, M., Rudland, E. and May, R. J. (eds) Burma-Myanmar: Strong Regime, Weak State? Adelaide: Crawford House Publishing, pp. 241-77.

Mangrai, S. S. (1965) The Shan States and the British Annexation, Ithaca, NY: Cornell University, Southeast Asia Program, Data Paper No. 57.

- (ed.) (1981) The Padaeng Chronicle and the Jengtung Chronicle Translated. Ann Arbor, MI: University of Michigan, Center for South and Southeast Asian Studies. 
March, J. G. and Olsen, J. P. (1995) Democratic Governance, New York, London, Toronto: The Free Press.

Marshall, A. (2002) The Trouser People: A Story of Burma - In the Shadow of the Empire. Washington, DC: Counterpoint.

Martin, L. L. (1992) Coercive Cooperation: Explaining Multilateral Economic Sanctions, Princeton, NJ: Princeton University Press.

Masson, D. (1897) (ed.) The Collected Writings of Thomas De Quincey, London: A \& C. Black.

Maung Aung Myoe (2002) Neither Friend nor Foe: Myanmar's Relations with Thailand since 1988: A View from Yangon, Singapore: Institute of Defence and Strategic Studies, Nanyang Technological University.

Mayall, J. (1990) Nationalism and International Society, Cambridge: Cambridge University Press.

Mayall, J. and Lyons, G. M. (2003) 'Human Rights and International Politics', in Lyons, G. M. and Mayall, J. (eds) International Human Rights in the 21st Century: Protecting the Rights of Groups, Lanham, MD, Boulder, CO, New York, Oxford: Rowman and Littlefield Publishers, Inc., pp. 200-17.

Metford, B. (1935) Where China Meets Burma: Life and Travel in the Burma-China Border Lands, London: Blackie and Son Ltd.

Ministry of Health (2001) Health in Myanmar, Yangon: Ministry of Health.

Mitton, G. E. (1936) Scott of the Shan Hills: Orders and Impressions, London: John Murray.

Moscotti, A. D. (1950) British Policy in Burma, 1917-1937: A Study in the Development of Colonial Self-Rule, a dissertation presented to the Faculty of the Graduate School of Yale University in Candidacy for the degree of Doctor of Philosophy, June 1950, Ann Arbor, MI: University Microfilms; revised (1974) as British Policy and the Nationalist Movement in Burma 1917-1937, Honolulu, HI: University of Press of Hawaii.

Mullerson, R. (1997) Human Rights Diplomacy, London: Routledge.

Myanmar Information Sheet, 19 November 2003.

Myanmar Information Sheet, 27 November 2003.

Myanmar Institute of Strategic International Studies (2004) Seminar on Understanding Myanmar, Yangon: Myanmar Institute of Strategic International Studies.

Myanmar Times, 20 November 2003.

Myanmar Times, 8-14 December 2003.

Myanmar Times, 26 January 2004.

Myanmar Times, 30 May 2004.

Myanmar Times, 12 July 2004.

Myanmar Times, 8 October 2004.

Myint Shwe, 'Sanctions Miss the Mark', Bangkok Post, 18 April 2004.

National Commission for Environmental Affairs (NCEA) (1997) Myanmar Agenda 21, Yangon: Aung Din and Associates.

Nef, J. (1995) Human Security and Mutual Vulnerability: An Exploration into the Global Political Economy of Development and Underdevelopment, Ottawa: International Development Research Centre.

New Light of Myanmar, 27 November 2003.

Noda, P. J. (ed.) (1998) The Asian Crisis and Human Security: An Intellectual Dialogue on Building Asia's Tomorrow, Tokyo and Singapore: Japan Center for International Exchange and Institute of Southeast Asian Studies.

— (ed.) (1999) Sustainable Development and Human Security, Singapore: Institute of Southeast Asian Studies. 


\section{Bibliography}

Nolutshungu, S. C. (ed.) (1996) Margins of Insecurity: Minorities and International Security, Rochester, NY: University of Rochester Press.

Nossal, K. R. (1994) Rain Dancing: Sanctions in Canadian and Australian Foreign Policy, Toronto and London: University of Toronto Press.

Nussbaum, M. (2000) Women and Human Development: The Capabilities Approach, Cambridge: Cambridge University Press.

Ohmae, K. (1995) The End of the Nation State: The Rise of Regional Economies, New York and London: The Free Press.

Onuma, Y. (2000) 'Towards an Intercivilizational Approach to Human Rights', in William Krull (ed.) Helen Schoop (trans.) Debates on Issues of Our Common Future, Gottingen: Velbruck Wissenschaft.

Oudrat, C. de Jonge (2000) 'Making Economic Sanctions Work', Survival, 42(3): 105-27.

Owen, D. E. (1934) British Opium Policy in China and India, New Haven, CT: Yale University Press; London: Humphrey Milford; Oxford: Oxford University Press.

Pape, R. (1997) 'Why Economic Sanctions Do Not Work', International Security, 2: 90-136.

Paske, C. (1893) Myamma: A Retrospect of Life and Travel in Lower Burmah, London: WH Allen \& Co.

Pedersen, M., Rudland, E. and May, R. (eds) (2000) Burma-Myanmar: Strong Regime, Weak State? Adelaide: Crawford Publishing House.

Pickvance, C. and Preteceille, E. (eds) (1991) State Restructuring and Local Power: A Comparative Perspective, London and New York: Pinter.

Putnam, R. D., Leonardi, R. and Nanetti, R. Y. (1993) Making Democracy Work: Civic Traditions in Modern Italy, Princeton, NJ: Princeton University Press.

— (2000) Bowling Alone: The Collapse and Revival of American Community, New York and London: Simon and Schuster.

Rae, H. (2002) State Identity and the Homogenisation of Peoples, Cambridge: Cambridge University Press.

Ramcharan, B. G. (2002) Human Rights and Human Security, The Hague, London: Martinus Nijhoff.

- (2002a) The Security Council and the Protection of Human Rights, The Hague: Martinus Nijhoff.

Ravenhill, J. (2001) Apec and the Construction of Pacific Rim Regionalism, Cambridge: Cambridge University Press.

Renard, R. D. (1986) 'The Integration of Karens in Northern Thai Political Life during the Nineteenth Century', in Renard, R. D. (ed.) Anuson Walter Vella, Chiang Mai and Honolulu, HI: Walter F Vella Fund, Payap University and Center for Asian and Pacific Studies, University of Hawaii, pp. 229-48.

— (1996) The Burmese Connection: Illegal Drugs and the Making of the Golden Triangle, Boulder, CO: Lynne Rienner Publishers.

— (2001) Opium Reduction in Thailand 1970-2000: A Thirty-Year Journey, Chiang Mai: Silkworm Books.

Reus-Smit, C. (1999) The Moral Purpose of the State: Culture, Social Identity and Institutional Rationality in International Relations, Princeton, NJ: Princeton University Press.

(ed.) (2004) The Politics of International Law, Cambridge: Cambridge University Press.

- (2004a) American Power and World Order, Cambridge: Polity Press.

Risse, T., Ropp, S. C. and Sikkink, K. (eds) (1999) The Power of Human Rights: International Norms and Domestic Change, Cambridge: Cambridge University Press. 
Robinson, M. (1999) 'Addressing the Gap between Rhetoric and Reality', in Danieli, Y., Stamatopoulou, E. and Dias, C. J. (eds) The Universal Declaration of Human Rights: Fifty Years and Beyond, Amityville, NY: Baywood Publications Co.

Rosenau, J. N. (1997) Along the Domestic-Foreign Frontier: Exploring Governance in a Turbulent World, Cambridge: Cambridge University Press.

Roy, D. (ed.) (1997) The New Security Agenda in the Asia-Pacific Region, Basingstoke and New York: Macmillan and St Martin's Press Inc.

Sachdeva, G. (2000) 'India-China Economic Cooperation in a Growth Quadrangle?' in Bajpai, K. and Mattoo, A. (eds) The Peacock and the Dragon: India-China Relations in the 21st Century, New Delhi: Har-Anand Publications, pp. 219-28.

Schak, D. and Hudson, W. (eds) (2003) Civil Society in Asia, Aldershot: Ashgate.

Schultz, K. A. (2001) Democracy and Coercive Diplomacy, Cambridge: Cambridge University Press.

Scott, J. C. (1985) Weapons of the Weak: Everyday Forms of Peasant Resistance, New Haven, CT and London: Yale University Press.

Scott, J. G. 'Diary of a Tour to the Shan States, 1897', Scott MS collection, Cambridge University Library, U.L. 1.5-1.6.

Scott, J. G. and Hardiman, J. P. (1901) Gazetteer of Upper Burma and the Shan States, 2 vols, Rangoon: Government Printer.

Scott, J. M. (1969) The White Poppy: A History of Opium, London: Heinemann.

Scott, M. S. collection, Cambridge University Library, U.L. 1.2-U.L. 1.9.

Seekins, D. M. (2005) 'Burma and U.S. Sanctions', Asian Survey, 45(3): 453-74.

Seligman, A. (1992) The Idea of Civil Society, New York: The Free Press.

Selth, A. (1996) Transforming the Tatmadaw: The Burmese Armed Forces since 1988, Canberra, Strategic and Defence Studies Centre, ANU.

_ (1996a) 'Burma and Exotic Weapons', Strategic Analysis, 19(3): 413-33.

_ (2002) Burma's Armed Forces: Power without Glory, Norwalk, CT: EastBridge.

Sen, A. (1999) Development as Freedom, New York: Alfred A Knopf. (1999a) 'Beyond the Crisis: Development Strategies in Asia', in Noda, P. J. (ed.) Sustainable Development and Human Security, Singapore: Institute of Southeast Asian Studies, pp. 15-37.

Sen, A. and Dreze, J. (eds) (1999b) Omnibus: Comprising Poverty and Famines, Hunger and Public Action, and India: Economic Development and Social Opportunity, New Delhi and New York: Oxford University Press.

Seng Raw (2001) 'Views from Myanmar: An Ethnic Minority Perspective', in Taylor, R. H. (ed.) (2001) Burma: Political Economy under Military Rule, London: Hurst, pp. 159-63.

- (2004) 'The Role of Minorities in the Transitional Process', in Badgley, J. (ed.) Reconciling Burma/Myanmar: Essays on U.S. Relations with Burma, vol. 15, no. 1, Seattle, WA: National Bureau of Asian Research, pp. 67-72.

Serrano, I. (1994) Civil Society in the Asia-Pacific Region, Washington: CIVICUS.

Silverstein, J. (1972). The Political Legacy of Aung San, Ithaca, NY: Southeast Asia Program Data Paper No. 86: Cornell University Press.

- (1977) Burma: Military Rule and the Politics of Stagnation, Ithaca, NY, Cornell University Press.

- (1980) Burmese Politics: The Dilemmas of National Unity, New Brunswick, NJ: Rutgers University Press.

(ed.) (1989) Independent Burma at Forty Years, Ithaca, NY, Southeast Asia Program: Cornell University Press. 


\section{Bibliography}

Simon, S. W. (ed.) (1993) East Asian Security in the Post-Cold War Era, New York: M.E Sharpe Inc.

— (ed.) (2001) The Many Faces of Asian Security, Lanham, MD: Rowan and Littlefield Publishers.

Skidmore, M. (2004) Karaoke Fascism: Burma and the Politics of Fear, Philadelphia, PA: University of Pennsylvania Press.

Smith, A. L. (2004) 'Solidifying Regional Cohesion, Advancing External Linkages', Contemporary Southeast Asia, 26(3): 416-33.

Smith, D. E. (1965) Religion and Politics in Burma, Princeton, NY: Princeton University Press. Smith, M. (1996) Fatal Silence? Freedom of Expression and the Right to Health in Burma. London: International Centre against Censorship.

- (1991, rpt. 1999) Burma: Insurgency and the Politics of Ethnicity, London and New York: Zed Books; Bangkok: White Lotus; Dhaka: The University Press.

Smith, M. J. (2000) Rethinking State Theory, London and New York: Routledge.

Smoljan, J. (2003) 'The Relationship between Peacebuilding and Development', Conflict, Security and Development, 3: 234-50.

Sommers, L. M., Mehretu, A. and Pigozzi, B. W. (2001) 'Globalization and Economic Marginalization: North-South Differences', in Jussila, H., Majoral, R. and DelgadoCravidao, F. (eds) Globalization and Marginality in Geographical Space: Political, Economic and Social Issues of Development in the New Millennium, Ashgate: Aldershot pp. 24-36.

Starkey, D. (2004) Six Wives: The Queens of Henry VIII, London: Vintage.

Steinberg, D. I. (1982) Burma, a Socialist Nation of Southeast Asia, Boulder, CO: Westview Press.

- (2000) 'The State, Power, and Civil Society in Burma-Myanmar: The Status and Prospects for Pluralism', in Pedersen, M., Rudland, E. and May, R. J. (eds) Burma/Myanmar: Strong Regime, Weak State? Adelaide: Crawford House Publishing.

(2001) Burma: The State of Myanmar, Washington: Georgetown University Press.

Stelle, C. S. (1981) Americans and the China Opium Trade in the Nineteenth Century, New York: Arno Press.

Straits Times, 30 June 2004.

Straits Times, 11 August 2005.

Strange, S. (1996) The Retreat of the State: The Diffusion of Power in the World Economy, New York: Cambridge University Press.

Sukma, R. (2001) 'Human Security and Political Stability: Should there be a Tension?' in Thiparat, P. (ed.) (2001) The Quest for Human Security: The Next Phase of ASEAN? Bangkok: Institute for Strategic and International Studies, Chulalongkorn University, pp. 53-66.

Sylvester, C. (2002) Feminist International Relations: An Unfinished Journey, Cambridge: Cambridge University Press.

Taipei Times, 24 July 2004.

Tan, S. and Cossa, R. A. (2001) 'Rescuing Realism from the Realists: A Theoretical Note on East Asian Security', in Simon S. (ed.) The Many Faces of Asian Security, Lanham, MD: Rowan and Littlefield Publishers, pp. 15-47.

Taylor, H. (1944) Behind the Ranges: Fraser of Lisuland SW China, London: Lutterworth Press.

Taylor, H. and Pedersen, M. (2005) 'Supporting Burma/Myanmar's National Reconciliation Process: Challenges and Opportunities', an independent report for the European Commission, January 2005. 
Taylor, R. H. (1987) The State in Burma, London: C. Hurst; Honolulu, HI: University of Hawaii Press.

_ (1998) 'Myanmar: Military Politics and the Prospects for Democratisation', Asian Affairs, 29 (1): 3-13.

(2001) Burma: Political Economy under Military Rule, London: Hurst.

(2004) 'Myanmar: Roadmap to Where?' Southeast Asian Affairs 2004, Singapore: Institute of Southeast Asian Studies, pp. 171-84.

(2004a) 'The Art of the Possible in Myanmar', Straits Times, 30 June 2004.

Tegenfeld, D. (2001) 'International Non-Government Organizations in Burma', in Taylor, R. H. (ed.) Burma: Political Economy under Military Rule, London: C. Hurst, pp. 109-18.

Tehranian, M. (ed.) (1999) Asian Peace: Security and Governance in the Asia-Pacific Region, London: I B Tauris and Toda Institute for Global Peace and Policy Research.

Tendler, J. (1997) Good Government in the Tropics, Baltimore, MD and London: Johns Hopkins University Press.

Thakur, R. (1997) 'From National to Human Security', in Harris, S. and Mack, A. (eds) Asia-Pacific Security: The Economics-Politics Nexus, St Leonards: Allen and Unwin, pp. 52-80.

- (2005) 'Absolute Security Neither Possible Nor Desirable: Civil Rights Should Not Be Forfeited for Temporary Safety', The Canberra Times, 29 July 2005, p. 13.

Thiparat, P. (ed.) (2001) The Quest for Human Security: The Next Phase of ASEAN? Bangkok: Institute for Strategic and International Studies, Chulalongkorn University.

Thomas, C. (2000) Global Governance, Development and Human Security: The Challenge of Poverty and Inequality, London: Pluto Press.

Thompson, P. (1976) China: The Reluctant Exodus, Sevenoaks: Hodder and Stoughton.

Thoreau, H. D. (1854, rpt. 1949) Walden, or Life in the Woods, London: J. M. Dent \& Sons Ltd; New York: E. P. Dutton \& Co. Inc.

Tin Maung Maung Than (1998) 'Myanmar: Preoccupation with Regime Survival, National Unity and Stability', in Muthiah Alagappa (ed.) Asian Security Practice: Material and Ideational Influences, Stanford, CA: Stanford University Press, pp. 390-416.

- (2002) 'Burma/Myanmar in 2001', Asian Survey, 42(1): 115-23.

Tin Maung Maung Than and Mya Than (2001) 'ASEAN Enlargement and Myanmar', in Mya Than and Gates, C. (eds) ASEAN Enlargement: Impacts and Implications, Singapore: Institute of Southeast Asian Studies, pp. 249-61.

Tow, S. (2004), 'Southeast Asia in the Sino-U.S. Strategic Balance', Contemporary Southeast Asia, 26(3): 434-59.

Trocki, C. (1999) Opium, Empire and the Global Political Economy: A Study of the Asian Opium Trade, London and New York: Routledge.

Turton, A. (ed.) (2000) Civility and Savagery: Social Identity in Tai States, Richmond, VA: Curzon Press.

UNDP (1994) Human Development Report 1994, Oxford and New York: Oxford University Press.

- (2001) Human Development Report 2001: Making New Technologies Work for Human Development, Oxford: Oxford University Press.

— (2002) Human Development Report 2002, Oxford and New York: Oxford University Press. www.mofa.go.jp/region/asia-paci/myanmar/index.html

United Nations (1993) World Conference on Human Rights: The Vienna Declaration and Programme of Action, New York: UN Department of Public Information.

Walker, W. O. (1991) Opium and Foreign Policy: The Anglo-American Search for Order in Asia, 1912-1954, Chapel Hill, NC: University of North Carolina Press. 


\section{Bibliography}

Wallensteen, P., Staibano, C. and Eriksson, M. (2004) 'Routes to Democracy in Burma/Myanmar: The Uppsala Pilot Study on Dialogue and International Strategies', Stockholm: Uppsala University, pp. 1-16 (www.smartsanctions.se - accessed 26 April 2004).

Warner, R. trans. (1954; rev. edn 1972) Thucydides: History of the Peloponnesian War, Introduction and Appendices by Finley, M. I. London: Penguin Books.

Williams, C. (1868) Through Burmah to Western China: Being Notes of a Journey in 1863 to Establish the Practicability of a Trade-Route between the Irrawaddi and the Yang-tsekiang, London: William Blackwood and Sons.

Wong, J. Y. (1998) Deadly Dreams: Opium, Imperialism, and the Arrow War (1856-1860) in China, Cambridge: Cambridge University Press.

Woodman, D. (1962) The Making of Burma, London: Cresset Press.

World Bank (2002) World Development Report 2000/2001: Attacking Poverty, New York: Oxford University Press.

Yang, L. (1997) The House of Yang: Guardians of an Unknown Frontier, Sydney: Bookpress, National Library of Australia.

Yegar, M. (2002) Between Integration and Secession: The Muslim Communities of the Southern Philippines, Southern Thailand, and Western Burma/Myanmar, Lanham, MD, Boulder, CO, New York, Oxford: Lexington Books. 


\section{Index}

Abu-Ghraib 42

Acharya, A. 2, 12, 13, 27, 29, 31, 49, 50,51

Addicts 88, 101

Afghanistan 74, 113, 136

Agrarian 4

Agricultural ecology 74

Akha 80, 81, 88

Alagappa, Muthiah 2, 48, 49, 155, 156, 157

Alaungpaya 144

Alima 82

All Burma Students Democratic Front (ABSDF) 156, 157

Amarapura 144

The American Democrat 42

American merchants 90

American missionaries 99

American security umbrella 29

Amnesty International 42, 53, 125

Amoy 97

Anderson, John 93

Anglo-Burmese War 1824-6, 94, 115

Anhwei 97

Annan, Kofi 8, 9, 25, 52, 59, 137

Anti-British confederation 87

Anti-Fascist Peoples Freedom League (AFPFL) 143

Anti-opium League 98, 99

Anti-opium movement 96, 97, 99

Arab traders 89

Arakan 94

Arrow War 90, 91, 94

ASEAN-China Business Council 109

ASEAN Free Trade Agreement 31, 48, 121

ASEAN-India Regional Trade and Investment Agreement (RTIA) 113

ASEAN-Institute for Strategic International Studies (ISIS) 29
ASEAN-Japan Exchange Year 121

ASEAN Regional Forum 2, 29, 30, 113, 119,131

ASEAN security pact 121

ASEAN Way 29, 49, 50, 51

Ashley, Lord (Shaftesbury) 97

Asia 12, 88

Asia-Europe Meeting (ASEM) 31, 51, $116,131,133,139$

Asian Development Bank 1, 107, 119

Asian Financial Crisis 25, 26

Asian governments 26, 27, 28

Asian security policy 29

Asian security practice 2,31

Asian values 42

Asia-Pacific 1, 2

Association of Southeast Asian Nations

(ASEAN) 2, 15, 26, 27, 29, 31, 34, $45,46,47,48,50,51,52,54,55,56$, $104,105,106,115,116,117,118,119$, $120,121,122,123,131,133,134,139$, $141,149,165,173,174$; Norm of non-intervention 48 ; Norm of regional solidarity 50 ; Security community 49,51

Athens 5

Athin movement 6

Augustine Heard and Company 90

Aung San 5, 68, 142

Aung San Suu Kyi 5, 6, 37, 46, 48, 50, $57,59,118,121,123,125,127,132$, 143,163

Australia 8, 15, 89, 94, 123, 124; Australian Minister for Foreign Affairs 9; Australian Prime Minister 12, 123

Australia-IMF Scholarship Program for Asia 124

Australian Centre for International Agricultural Research (ACIAR) 123 
Australian government 56, 168

Australian Red Cross 123

Australian Secret Intelligence

Organization (ASIO) 167

Authoritarian governments 104

Authoritarianism 5

Autonomy 64, 65

Ava 144

Axworthy, Lloyd 11

Ayeyarwaddy river 71

Ayudhya, Siamese kingdom of 94;

Burmese sacking of (1767) 114

Bagan economic summit 119

Bagan era xii

Balkans 8

Bandung conference 35

Bangkok conference 100, 101

Bangkok process 50

Bangladesh 2, 38, 65, 112, 113, 120, 174

Ba Nyein 143

Barsony, Andras (Hungarian Deputy

Foreign Minister) 131

Bayinnaung, Burmese king (1551-81) 94, 142

Benares 89, 92, 93

Bengal drug 91, 93

Beslan 10, 20

Bhamo 94

Bhutan 119

BIMST-EC 2, 112, 119

Black-market 87

Bodawpaya, Burmese king (1784-1819) 94

Bombay 90, 92, 93, 95

Border regions 58, 70, 72, 83, 87, 115, 119,152

Bosnia 11, 148

Boutros-Ghali, Boutros 16, 178 n.6

Boycott 6, 46

Brent, Charles, Episcopal Bishop to The Philippines 99

Britain 2, 35, 67

British colonial administrators 93; Administration 95, 96

British cotton and woollen goods 94

British empire 96

British India 88, 94, 101

British opium smugglers 91

British territory 90

Bronitt, Simon 170

Brown, George 92

Browne, Horace 93
Brundtland Commission 29

Brunei 31, 118, 119

Buddhist groups 65, 120; Communities 28

Bull, Hedley 13, 17

Bullock Brothers 94, 95

Burma/Myanmar 1, 2, 5, 6, 7, 58, 59, 61, $65,67,81,82,83,87,92,93,94,95$, $97,99,102,114,127,132,142,143$, 144, 145, 146, 147, 155, 161, 162; Burmah 3; Konbaung Burma 94

Burma-China Boundary Commission 82

Burma Freedom and Democracy Act (2003) 106, 135, 154

Burma-Thai border 87

Burma UK campaign 125, 138

Burmese 6,142; Army 81; Communist Party 86; Diaspora 35, 102, 124; Leaders 7; Military 68, 125; Monarchs 142; Resistance 2

Burma Socialist Program Party (BSPP) 126, 128

Burmese Way to Socialism 53

Bush administration 136

Buzan, Barry 2

Byamaso A-thin 156

Calcutta 92, 93, 95

Cambodia 18, 37, 38, 113, 121, 124,126

Cambridge University 11

Camdessus, Michael 59

Canada 8, 12, 24; Canadian approach 11; Canadian Minister for Foreign Affairs and International Trade 11

Canton 90

Capabilities xii, 141

Capacity-building 121

Care Australia 123

Castlereagh 30

Ceasefire groups $70,72,79,80,158$

Ceasefires 60,61

Central Committee for Drug Abuse Control (CCDAC) 58, 74, 80

Central Intelligence Agency (CIA) 87

Chakri Dynasty (1782-) 94

Children 10, 11, 20, 79

Child soldiers 39

Childwise 123

Chin 65, 103

China 24, 31, 34, 35, 38, 62, 74, 81, 87, $88,89,90,91,92,93,96,97,98,101$, $105,107,108,109,110,114,118,119$, $122,124,131,135,138,139,148,149$, 
155, 161, 162, 164, 172, 174; Backdoor to 94,109 ; Bilateral trade with India 114; Council for the Promotion of International Trade 109; Economic growth 106; Foreign Minister Li Zhaoxing 46; People's Republic of 28; Premier Wen Jiaobao visit to India 2005 114; Recognition of Sikkim being within Indian sphere of influence 114 China Inland Mission 94

Chinese 87, 88; Assistant Minister of Commerce, Qian Jiang 107; Chamber of International Commerce 109; Government 90, 96, 97, 99

Chinese Imperial Edicts 89, 90

Chinese Nationalist 87

Chinese Premier Wen Jiaobao 106

Chinese Revolution in 1911 94, 97

Ch'ing Dynasty 96

Chin state 112, 123

Chiu Chao Chinese 85

Choonavan, Chatchai 37

Chou En-lai 87

Christian Science Monitor 125

Churchill 88

Citizenship 43

Civil conflicts $15,70,72,103$

Civilian rule 143

Civilized states 24, 25

Civil rights 23, 26, 166, 167; Civil and political rights $167,169,170,171$

Civil society $1,2,4,10,25,27,29,32$, $41,42,43,44,45,53,129,147,148$, $151,153,154,155,156,157,165,170$, $171,172,173,174,175$; groups 5,52 , $56,116,119$; organizations 51 ; political and civil society 43 ; universalist Western paradigm 43

Civil war 6, 35, 53, 61, 66, 67, 86, 125,126

'Clean' faction 143

Clinton Administration 52, 127

Coalition of the willing 19

Coast-guard facilities 122

Cohen and Arato 155

Cold War 1, 9, 11, 16, 27, 28, 29, 52, 87, $88,89,100$

Collective identity 49, 50, 170, 173

Collignon 53-4

Colonial administration 87, 94

Colonial era $6,82,83$

Colonialism 13

Commissioner Lin 90

Commissioner Yeh 91
Commission on Security and Cooperation in Europe (CSCE) 29

Committee Representing the People's Parliament 162

Communal disturbances 120

Communist 87

Communist Party of Burma (CPB) 39, 88, 156

Confessions of an English Opium-Eater 97

Confidence-building measures 119

Conflict prevention 21

Conflict-riven societies 25

Constitution 119, 149

Constructive Engagement 37, 50, 56,115

Constructivist formulations 49

Containing Communism 110, 143

Cooper, James Fenimore 42

Correlation of Man and His Environment 53

Corruption 42, 102, 144

Council for Security Cooperation in the Asia-Pacific 29

Counter-terrorism measures 119

Country ships 89

Covenant 16

Crop-substitution programmes $73,75,76$, 77, 79, 83

Cross-border trade 38,78

Currency 4, 87, 122

Daewoo International Corporation 122

Darfur 11, 34, 41, 148

Demi-democracies 4, 104

Democracy 5, 23, 150, 171; Activist groups 145, 149; Parliamentary 53, 61, 104

Democracy movement 5

Democratic institutional parabola 170

Democratic state 2, 23

Democratic Voice of Burma (DVB) 162

Deng Xiaoping 107

Dent and Company 88, 90

Depiyin 6, 48, 50, 56, 103, 104

Developing states 24

Development and security 60

Dickens, David 11

Dictator's Dilemma 105

Dictatorship 5

Directorate of Defense Services Intelligence (DDSI) 48

Disciplined Democracy 104

DLA Piper Rudnick Gray Cary 158

Donne, John 16 
Downer, Alexander 9, 123

Drug Enforcement Administration (DEA) 83

Drugs 59, 74, 79; Prohibition on in Burmese empire 94

Drug suppression 1, 89, 96, 100, 101, 102, 123; Addiction 89; Control 101, 111, 123, 176; Eradication 88, 89; Operations 73, 86; Rise in demand 93; Warlords 102, 126

Drug trade 2, 38, 72, 81, 83, 85, 91; Tax on transport through EIC territory 90 ; Traffickers 74, 83; Trafficking 11, 148 Dupont, Alan 2, 28, 33

Dutch 89

Dutch East Indies 89

Dyarchy 3

Dynamic of conflict and resistance 58

Dynamic of secession-integration 67

Eastern Europe 65

Eastern Shan States xii, 61, 62, 63, 70, $72,73,74,83,123$

East Timor 11, 15, 31

Economic, social and cultural rights 26

Economic development 4, 7, 12, 105

Economic investment 147

Economics and security 122

Economies in transition 124

Eduljee, Rustomjee 93

Elections 3, 142, 144, 164

Electoral law 3

Elgin, Lord 91

Empowerment 2, 4

Enemies of the state 59, 73

Enforcement operations 89

Engagement policy 123, 124, 146

English East India Company (EIC) 89, 90, 94

Ethnic cleansing 11, 20, 41, 65; conflict 7; insurgencies 35,53 ; minority $57,58,60,63,64,65,67$, $70,95,103,125,152$; violence 8

European Commission 131

European Union (EU) 2, 35, 46, 124, 125, $130,131,132$

Evans, Gareth 30

Famines xii

Far Eastern Economic Review (FEER) 122

Fear of freedoms 7

Federated Shan States 101

Fiery Cross 92
First Toungoo Dynasty 142

Flexible engagement 50, 115

Food insecurity 58

Food security 79

Food shortages 4

Forced labour 39, 148

Foreign aid and investment 120

Four Cuts Policy 86

Four Eights democratic movement 153

France 149

Fraser, J. O. 82, 94

Freedom: of association 4; from fear 1, 4, $5,7,11,12,16,17,21,26$; from want $1,4,5,7,12,16,17,21,26$; of the Press 4

Frontier 10, 87; Areas 96; Frontier peoples 87

General Council of Burmese Associations (GCBA) 6

General Council of Sangha Sametgyis (GCSS) 6

Geneva conference 100, 101

Geneva Conventions 23

Genocide 10, 14, 20, 125; Cambodian 14

Genser, Jared 149, 159

Germany 12, 63, 131

Global Fund 147

Globalization 11, 13

Golden Triangle 75, 78, 80, 86, 88, 89,102

Good neighbour policy 115

Governance 1, 5, 14, 22, 50; Authoritarian $56,105,133,141,142,143,146$, 157; Democratic xii, 25, 27, 56, 60, $115,123,124,126,138,149,153$, 164, 176; Global 24; Good governance 22; Medieval 141, 145; Military 7, 126, 145; Norms of 53; Participatory 25

Government 3, 5, 27; Australian 123; in Bengal 90; of Burma 101; Caretaker 68; Constitutive 55; Democratic 144; of India 96; Post-colonial 88

Greater Mekong Sub-region 119

Grey, Sir Edward, Foreign Secretary 96

Group rights 21, 73, 170, 171

Growth quadrangle South-West China/Yunnan, North-East India, Myanmar and Bangladesh 114

Guantanamo Bay 42, 136

Gunboat diplomacy 25 
Hanoi 31, 131

Harris, Stuart 2

Harris, Townshend, US Envoy to Japan 100

Hartal 6

Hastings, Warren (Governor of Bengal) 89

Havel, Vaclav (former President of Czech Republic) 148, 149, 158, 161; Havel-Tutu report 158, 161

Hawaii 9

Haws (Panthay Muslims) 82, 85

Heho 71

Heroin 82, 84, 85, 87; Ban on 101; Refineries 85

Hill tribes 86, 87, 88

HIV/AIDS 1, 9, 11, 109, 121, 123, 131, $140,145,147,148,154,157,159$, 161,176

Hkam Aung, Colonel 74

Hmong (Meo) 80, 88

Hong Kong 90, 92, 93

Hosie, Sir Alexander, Consul General in Tientsin 97

House of Commons declaration 190696

House of Lancaster 141

House of York 141

Hsenwi 88

Huguenots 41

Hukawng Valley 82, 86, 101

Human development 1, 16

Human insecurity 12, 16, 36, 57, 59, 66

Humanitarian aid 123, 131

Humanitarian assistance 121, 148, 152, 165; Politicization of 148

Human resource development 121

Human rights 4, 8, 11, 12, 14, 20, 22, 27 , $41,52,54,55,124,127,129,134$, 146, 147, 148, 150, 161, 164;

Commission 57; Protection of 21, 27 , 145; Repression of 53; Securitization of 52, 53; Workshops 56

Human Rights Watch 42, 53, 125, 168

Human suffering 9

Human trafficking 1, 9, 109, 119 , 123,176

Human well-being 8, 10, 145

Identity transformation 57

India $2,15,16,35,38,88,89,95,97$, $105,107,110,111,114,118,135,138$, 149, 155, 161, 163, 173; Look East policy 113; Strategic role in sustaining regional peace 114
India-Bangladesh tensions 120

India-China opium trade 90

India-Myanmar Bilateral Agreement 111

India-Myanmar economic cooperation 120

Indian Defense Minister, George Fernandes 108

Indian Ocean rim 9, 108

Indian opium 93

Indian Prime Minister 111, 112

Indian traders 90

Indian Vice-President 110, 111

Indigenous ethnic minority peoples 58 , $68,70,72,73,80,171$; Leadership 75

Indigenous NGO 44

Indigenous peoples $61,69,73$

Indigenous Rights 73

Individual rights and collective rights 73

Indo-Chinese Opium Trade 97

Indonesia 26, 31, 49, 50, 104, 118, 119, 126,144

Institutional changes 4

Insurgent groups 38, 60, 61, 62, 102,112

Integrated development projects 83

Intellectual dialogue 11

Inter-ethnic violence 21

Internal colonialism 68

International aid 56, 121, 157

International Commission on Intervention and State Sovereignty (ICISS) 14,15 , $18,19,20,30$

International Committee of the Red Cross (ICRC) 53, 125, 150

International community $15,18,35,45$, $46,51,52,56,72,142,149,150,151$, $152,160,175,176$

International Criminal Court 10, 52

International drug marketing syndicates 89

International drug trade 82

International human rights law 170

International Labour Organization (ILO) $46,57,125$

International law 10, 14, 24, 52

International market economy 103

International Military Tribunal for the Far East (IMTFE) 100

International narcotics regulation 99

International narcotics suppression regime 83,96

International networks $85,88,89,102$

International NGOs 42, 46, 123, 125, 146

International Opium Convention 101 
International opium merchants 90

International policy on opium 96

International politics 145

International regulatory regime 96

International relations 13, 25, 60; Policy 105,129

International security 4

International society $28,34,35,61$

International Year of Indigenous Peoples 73

Inter-state conflict 33

Intervention 18, 19, 20, 21, 148; Military $24,148,149$

Intra-state $10,11,19$

Iran 88

Iraq $19,24,25,30,35,105,113$, 136,149

Iselin Commission 38

Islamic fundamentalism 139

Israel 108

Jagan, Larry 47, 130, 164

Jakarta 15

Janjaweed 11

Japan $8,11,12,28,31,50,54,63,88$, $100,105,107,120,121,122,131$

Japanese Foreign Policy 11; Prime

Minister 11, 122

Jardine-Matheson 88, 90, 91, 92, 93, 94, 97; Jardine, William ('Iron-headed old rat') 90

Jeejeebhoy, Sir Jamsetjee 90

Kachin 38, 44, 67, 84, 85, 88, 94, 96

Kachin hills 101

Kachin Independence Organization 156

Kachin State 82, 86, 101, 153

Kaempfer, Engelbert 89

Ka Kwe Ye (KKY) 102

Kansu 97

Karen 67

Karen National Union (KNU) 38, 115, $156,157,158$

Karenni National Progressive Party 158

Kashmir 114

Kayah 67

Kengtung 49, 65, 66, 88, 101

Khin Nyunt 36, 38, 39, 46, 48, 57, 104, 105, 106, 108, 109, 113, 115, $121,126,129,139,141,144$, 147, 174

Khin Zaw Win, Dr 150, 151, 154

Khun Sa 85, 102

Kim, Woosang 21
Kimberley, Lord, Secretary of State for India 99

Kokang xii, 38, 67, 74, 79, 80, 83, $86,87,88,101$

Kokang Development Project 101

Kokangese 65, 80

Konbaung Dynasty 94, 142, 144

Kosovo 11

Kuhn, John and Isobel 82

Kuomintang 35, 87, 110

Kweichow 97

Kyaukse 120

Kyaw Win, Dr 39, 55

Lahu $80,81,84,88$

Landmines 11

Land Nationalization Act of 1953144

Land rights 73

Laos 37, 38, 89, 105, 113, 121, 124,143

Lashio 87

League of Nations 100, 101

Least Developed Country (LDC) 53, 60, 67

Leekpai, Chuan (former Thai Prime Minister) 115

Lee Kuan Yew 118, 119, 125, 126,134

Legitimacy 73, 142, 143

Lemahieu, Jean-Luc 79, 159

Liberalization of trade and investment 11

Lidderdale 93, 95

Lisu 80, 81, 82, 94

Lo Hsing-han 102

London Missionary Society 98

Luang Prabang 82

Lyons, Genee 20

McCullers, Carson 41, 43, 47

MacFarlane Burnet Institute 123

Macro-economic management 1, 124; Reforms 4

Mae Sai 49

Mae Sot 115

Magniac and Company 90

Malaria 1, 121, 145, 147, 148, 154

Malaysia 31, 50, 107, 118, 144; Former Prime Minister, Dr Mahathir 48, 50, 118

Malnutrition 4

Malwa 89, 90, 91, 92, 93

Manchukuo (Manchuria) 100, 101

Mandalay xii, 94, 103, 157

Mandalay to Momien (Teng-yueh) 93 
Mandalay Traders, Brokers and Industrialists Association 154

Mao 87, 89, 100, 101

Marcos, Ferdinand 56

Margary, Augustus 93

Marginality 65, 67, 68

Matheson, Donald 97, 98

Matheson, James 90

Maung Aye 36, 51, 130, 164

Mayall, James 13, 20

Medecins Sans Frontieres Australia 123

Medhurst, Dr 98

Medieval 141, 144, 145, 146

Meiktila xii

Mekong Operation 87

Mekong Sub-region 2

Menezes, de, Jean Charles 23, 168

Merchants of Manchester 94

Metta Development Foundation 44, 154

Metternich 30

Military government 5, 53, 88, 143, 152, 153; Dictatorship 142; Dominant role for in new Constitution 119; Domination of national political agenda 150; Takeover 3

Millennium Development Goals 59, 80,133

Mindon (King of Upper Burma 1852-78) 93

Ministry for the Progress of the Border Areas and National Races 38, 61, 80

Minority peoples 1,41

Minority rights 21

Missionaries 90, 94, 98

Mogaung 94

Mon 38, 67

Mong Ka 80

Mongolia 124

Mong Pauk 62

Mong Pyan 69-71

Mon-Khmer 65

Morely, John, Head of the India Office 96

Moscotti 6, 7

Muang La 82

Mughal emperors 89

Multi-ethnic state 2

Multilateral dialogue 29

Multilateralism 50

Muslim communities 28

Muslim population 55

Muslim Rohingya 65

Muslims 120

Myanmar 1, 2, 3, 4, 5, 31, 34, 35, 36, 37, $38,40,45,48,49,50,53,54,55,56$,
$60,89,103,104,106,115,118,119$, $121,122,123,127,131,133,136,138$, $139,141,142,144,148,149,150,151$, $152,154,155,158,159,162,163,164$, 168, 169, 170-4; Attack on embassy 115; Foreign Minister 45, 131, 142, 148; Government 60, 61, 70, 72, 74, 102, 107, 122, 148; Government-controlled press 115; Home Affairs Ministry 74; International relations policy 106,149 ; Joint Myanmar-US survey team 74; Military leaders 125; Ministry of Health 122; Myanmar/Burma 3, 22, 49, 88; Myanmar Institute of Strategic International Studies 37, 38, 39, 40, 44; Roads 72; Security enhancement 114; Social and political culture 44; Textile exporters 135

Myanmar Agenda 21141

Myanmar Maternal and Child Welfare Association (MMCWA) 121, 174

Myanmar Women's Affairs

Organization 154

Myitkyina 36, 150

Naga hills 101

Nam Hka 87

Nam Ko 82

Narathiwat 28

Narco-economy 74

Narcotics trade 96; Control 96; Laws 102

National and regional resilience 29

National Coalition Government of the Union of Burma (NCGUB) 144, 158

National Commission for Environmental Affairs (NCEA) 141

National Convention 35, 36, 39, 50, 130, $140,149,164,167,169,170,171$

National Endowment for Democracy 125, 145

National Intelligence Bureau 36

Nationalist movement 7

National League for Democracy 46, 68, $118,130,132,140,143,144$, 149,162

Nation state $10,12,13,14,65,67$, $68,70,72,73$

Neo-Gramscian 155

Neo-Tocquevillean 155, 156

Nepal 119

New Destiny Project 74

$\mathrm{Ne}$ Win 3, 35, 53, 68, 83, 118, 142, 143 , $144,153,173$ 
New Light of Myanmar 1

Ninth ASEAN Summit Bali 109

Nixon, Richard M. (US President) 89

Nobel Peace prize 5, 59; Nobel Peace prize winner, Bishop Desmond Tutu 148

Noda, Pamela 25, 51, 54

Non-aligned Movement 35

Non-government organization 44, 121, 146,153

Non-intervention 27

Non-violent resolution 4

Norms xii, 25, 31, 46, 49, 53, 55, 56, 57, $61,73,132,133,139,169$

North Korea 4, 28, 122

Norway 12

Norwegian Institute of International Affairs 12

Nuclear capacity 122,123

Nuclear submarine fleet 108

Nussbaum 2

Obuchi, Keizo 11, 26

Oceans 9; Indian and Atlantic 9

Offshore oil and gas exploration 112

Ohmae 14

Operation Hell-flower 74

Opium 84, 85, 87, 88, 89, 90, 91, 92, 93, 94, 95, 96, 97, 99, 100, 101, 102, 160; Addiction 94; Anti-Opium Edict 1906 96; Dens 96; Export to China 90; Fields of Yunnan 94; Jesus opium 98; Lamps, pipes and smoking paraphernalia 96; Legalized 91; Merchants 97; Monopoly 101; Producing nations 101; Request to end export of 96; Sale of opium in Burma proper 101; Shan opium 94; Social and economic cost of 94; Tax on opium brought into China 91 ; Used to pay for intelligence 96

Opium Act of 187595

Opium Advisory Committee 100, 101

Opium Enquiry Committee 101

Opium monopoly 88

Opium poppy 58, 73, 82, 89; Excise opium 88,95 ; Smoking of opium 80 , 89, 94, 100, 101; Trade 88, 92, 95, 96, 97, 98; Transporting companies 90

Opium yield survey 77

Organization for Economic Cooperation and Development (OECD) 1

Organization for Security and Cooperation in Europe (OSCE) 29
Pacific Rim 9

Pakistan 114

Palaung 72, 88

Palme Commission 28

Panglong 62, 82

Panthay rebellion 92, 93

$\mathrm{Pa}-\mathrm{O}$ 38, 72

Pariah 55, 56, 145

Parliamentary Democracy Party 142

Parsifal 149

Participatory development 75

Paske 3

Patna 89, 92, 93

Peacebuilding 21

Peacemaking 21

Penang 94

People's Liberation Army (PLA) 40, 87

Permanent Control Board 100

The Philippines 26, 31, 49, 50, 56, 104, 106, 119, 155

Pinheiro, Paulo Sergio 53, 162, 165, 170,171

Plural society 6

Policy: perspective 4, 12; public 10, 22

Political poverty xi

Political reforms 2

Political rights $4,5,11,26$

Pongyis 6

Poppy 72, 73, 74, 79, 82, 86, 88, 96, 101, 102; Blooms 92; Cultivation 81, 92, 93, 101, 165; Domestic poppy 92;

Eradication of 75, 97; Foreign opium 91; Native production of 91; Planting of forbidden 96; Poppy culture xii, 45, $58,63,75,102$; Poppy farmers 45,58 , $75,76,78,79,85$; Replacement 1

Portuguese 89

Post-colonial 3

Post-socialist societies 43

Poverty 4, 58-9, 133, 145, 160; alleviation $1,4,58,60,62,73,102$, 109, 120, 123, 174; Day 80

Prague Spring 141

Preparis reef 94, 95

Presbyterian Church in England 98

Presbyterian Mission Press 98

President Yuan Shih-k'ai 94

Property rights xi, 4, 54, 144

Public policy 134

Pyinmana 47, 107, 142, 164, 167

Rain dancing 129

Rakhine 65, 123 
Rama II (1809-24), Siamese king of Chakri dynasty 94

Rama III (1824-51), Siamese king of Chakri dynasty 94

Ramcharan, B. 21

Realist balance-of-power paradigm 103, 106

Reconciling Burma/Myanmar: Essays on US Relations with Burma 129

Reed, William (American Minister in Canton 1858) 91

Reform programme 141

Refugee flows $15,65,120$

Regime legitimacy 105

Regional capital market 122

Regional hegemon 103

Regionalism 48, 49, 51

Regional norms 49

Regional security 87, 118, 119, 124, 139

Reiver 94, 95

Reporters Sans Frontieres 4

Responsibility to Protect 14

Reus-Smit, Chris 17

Right to Development 61, 70, 132

Right to Secede 68

Risse, Ropp and Sikkink 55-7

Riuli 89

Roadmap to Democracy 36, 37, 115

Robertson 91

Robinson, Mary 16

Romany 65

Roosevelt, Theodore (US President) 99

Rosenau 10, 105

Royal Commission 99

Royal Navy 83

Russell and Company 88, 90

Russia 10, 23, 149, 161

Rwanda 11, 14, 18, 41, 52, 148

Ryots 90

St. John's College, Cambridge University 97

Sanctions 35, 50, 95, 103, 107, 108, 124, $126,127,128,130,131,132,133,134$, $135,137,139,140,145,146,173,175$; Targeted sanctions 129

Sasakawa Foundation 121

Sassoon, David and Sons 90, 91, 92, 97

Sathirathai, Surakiat (Thai Deputy Prime Minister) 115, 116, 129, 131

Scott, Sir James George (Shway Yoe) 38, $80,82,87,88$

Scott and Hardiman 88
Second World War 27, 31, 82, 85, 86, 87, $88,96,100,120,124$

Secure state 2

Security 1, 2, 149; Border security 111 ; Collective 30; Common 25, 27, 28, 30;

Community 29, 79, 119;

Comprehensive 12, 25, 27, 29, 31, 32, 33; Constructivist view 103; Cooperative 25, 27, 29, 30, 31; and Development 60; Domestic 105;

Energy security 111, 138;

Enhancement 103; Holistic security 2, 4, 28, 32, 33, 34; Human security 1, 4, $5,7,8,9,10,11,12,14,16,22,24,26$, $28,29,33,34,38,41,58,59,73,102$, 103, 157, 158, 161, 164; National 28, 102, 103, 164; Personal 79; Policy 27, 31,32 ; Regime security $2,27,28,38$, 103,105 , 165; State security $1,27,28$, $38,164,165$

Security Council 24, 52, 60

Self-determination $68,69,70,72,73$

Seligman, A. 42, 43, 44, 170

Sen $2,11,12,22,25,26$

Seng Raw 44, 45

Seven horsemen of the apocalypse 1 , 58,102

Seven vectors of human insecurity 16 , $60,66,148$

Severe Acute Respiratory Syndrome (SARS) 9

Shalom Foundation 156

Shan 67, 68, 80, 84, 85; Hotha Shans 93

Shanghai 91, 98, 100

Shanghai conference of 190996

Shanghai International Opium Commission 99, 100

Shan State xii, 71, 79, 84, 85, 87

Shan State Army (SSA) 102

Shan State Kokang Democracy Party 171

Shan States 68, 80, 88, 101

Shan States Opium Order 101

Shensi 97

Shinawatra, Thaksin 28, 36, 37, 49, 106, $115,116,153,173$

Siam 81, 88, 114

Siam-Burma Wars 114

Sierra Leone 11

Silverstein 5,6

Singapore $31,49,84,85,94,105,106$, 107, 118; Government of Singapore Investment Corporation 118

Singphos 94 
Sino-Thai business community 85

Skinner, John 95

Sladen, Edward Bosc 93

Smuggling of opium 96

Social development 4

Social instability and insecurity 93

Socialism 103, 150

Socialist 3

Socialist utopia 144

Socialization: of economy 86 ; of elites 50, 119; of international norms 57; phases 55

Social Movement Organizations (SMOs) 153,154

Social upheaval and communal violence 94

Socio-economic fabric 121, 131, 132, 133

Socio-economic policies 3, 25, 61, 102,121

Soe Win 36, 51

Southeast Asia 67, 84, 88, 89, 90, 114, 115,143

Southeast Asian countries 156

Southeast Asian governments 103

Southeast Asia Nuclear Weapons Free Zone (SEANWFZ) 123

Southeast Asia Treaty Organization (SEATO) 29

South Korea 26, 34, 54, 105, 122, 131

Sovereign state 102

Sovereignty $1,3,7,10,13,14,17,24,27$, $50,105,133,142,149$

Spain 170

Spiral model 55, 57

Srebenica 14

Sri Lanka 2, 126, 155

Ssu-ch'uan 88, 91, 97

'Stable' faction 143

State formation 67

State identity transformation 56

State Law and Order Restoration Council (SLORC) 53, 143, 144

State Peace and Development Council (SPDC) 35, 40, 46, 47, 53, 103, 105, $111,130,132,138,142,144,147,149$

State security 59,165

Stockholm Report 129

Student Generations since 1988 150, 152, 153,162

Substitute crops 101

Suharto 56, 104, 118

Sukma, Rizmal 27, 28

Sumatra 9, 12

Suphamongkonon, Kanthathi 105
Suppression of political dissent 27

Sustainability 118

Sustainable approach to governance 104

Sustainable change 151; in human rights behaviour 55

Sustainable democratic governance 129

Sustainable development xii, 25, 32, 59, 121, 157, 165; Johannesburg Conference 59

Sustainable reform programme 141, 164

Sustainable security 29

Sweden 12

Swedish Ministry of Foreign Affairs 129

Tachilek 49, 78, 83, 84

Taiping rebellion 92,93

Taiwan 54, 87, 89, 100, 105

Tatmadaw (Myanmar army) 39

Taunggyi 71,84

Taw Nio 82

Terms of trade 135

Terrorism 60, 158

Terrorist attack 10, 14, 22

Thai army 87

Thailand 2, 12, 26, 31, 34, 38, 49, 54, 74, $77,83,84,85,86,88,89,104,105$, $106,107,114,115,116,118,119,126$, $143,144,155,161,163,164,173$; 77-member Thai delegation 117; Former Foreign Minister, Surin Pitsuwan 50, 115; Thai Minister of Commerce Adisai Bodharamik 116

Thai Rak Thai 106

Thakur, Ramesh 23, 30, 32

Than Shwe 36, 46, 47, 51, 102, 105, 111 , $113,117,130,144,164$

Thiparat, Pranee 26, 27, 54

Thomas, Caroline 59-60, 68

Thoreau, Henry David 26

Threats 1,104

Thunder 93

Thura Shwe Mann 164

Tilowa 108

Tim Fischer Centre for Global Trade and Finance 60

Tonkin, Derek 143, 144, 158, 161, 163

Trade and investment initiatives 120

Transborder crime and piracy 122

Transparency International 42

Trans-Salween States 95, 96, 101

Treaties 10

Treaty of Amity and Cooperation 49

Treaty of Nanking 90

Treaty of Tientsin 90, 91 
Treaty of Westphalia 13

Trinity College 11

Tsunami 9, 12, 15, 51

Tuberculosis 1, 121, 145, 147, 148, 154

Tudor era 141

Turkey 88

Tutu, Bishop Desmond 148, 149, 157, 161

UK 2, 35, 124, 126, 133, 138, 149

U Khin Maung Win 40, 44

UNICEF 123

Union 3; of Burma 68

Union of Myanmar Chamber of Commerce and Industry (UMCCI) 154

Union of Myanmar Federation of Chambers of Commerce and Industry (UNFCCI) 109

Union Solidarity Development Association (USDA) 156, 157

United Nations 3, 8, 10, 147, 149, 153, 160; Charter 10, 30, 161; Covenants, Civil and Political, and Social, Economic and Cultural Rights 10, 52, 61; General Assembly 55, 142, 148; High Commissioner for Refugees 11; Millennium Summit 11; Secretariat 11; Security Council xi, 30, 148, 149, 150, 158, 161, 162; Special Envoy Tun Razali Ismail 118, 129; Special Rapporteur on Human Rights 22, 53; Working Group on Indigenous Peoples (WGIP) 73

United Nations Council on Trade and Development (UNCTAD) 59

United Nations Development Programme (UNDP) 1, 2, 8, 9, 16, 17, 22, 58, 147

United Nations Office of Drugs and Crime (UNODC) 58, 74, 79, 80, 86, 123, 147, $148,159,160,161$

United Wa State Army (UWSA) 61

Universal Declaration of Human Rights (UDHR) 10, 23, 52, 170

UNOCAL 135

$\mathrm{U} \mathrm{Nu} 3,35,61,83,87,96,101,143$

U Nyan Win 45, 148

US $2,12,23,35,107,119,124,126,135$, $138,147,149,160$; Foreign policy 87 , 133,145
USAEngage 136

US containment policy 106,109

US Department of State 83, 147; Foreign Operations and Related Programs Appropriations Act 2006147

US doctrine of pre-emptive strike 105

US military security umbrella 106

Victoria, Queen 90

Vienna Declaration and Programme of Action 61

Vietnam 37, 70, 86, 88, 105, 113, 119 , 121, 124, 126; War 70

Wa xii, 38, 40, 63, 64, 65, 79, 80, 82, 83, 84, 87, 88, 126; Leadership 74; Special Region 70, 72, 79; States 101

Wan Hong 75, 78

Warlords 94

War on Terror 2, 28, 138, 169, 174

War with Britain 1839-42 89

Western Europe 13

West Mang Lon 88

Williams, Clement 93

Wolfensohn, James 60

Wolfowitz, Paul 60

Wolsey, Cardinal 36

World Bank 1, 2, 4, 12, 22, 56, 60, 80, 145

World Food Programme 103

World Politics 8

World Trade Center 15

Yang family 88 ; Olive Yang 88

Yao 88

Yodya 115

Yong Kha 63, 75-7

Yoshiro Mori 11

Young Men's Buddhist Association (YMBA) 6

Yugoslavia 8

Yunnan 82, 86, 91, 92, 93, 97, 98; Yunnanese Chinese 85

Zero-sum game 142

Zimbabwe 34, 168, 169

Zone of Peace, Freedom and Neutrality (ZOPFAN) 123 
eBooks - at www.eBookstore.tandf.co.uk

\section{A library at your fingertips!}

eBooks are electronic versions of printed books. You can store them on your PC/laptop or browse them online.

They have advantages for anyone needing rapid access to a wide variety of published, copyright information.

eBooks can help your research by enabling you to bookmark chapters, annotate text and use instant searches to find specific words or phrases. Several eBook files would fit on even a small laptop or PDA.

NEW: Save money by eSubscribing: cheap, online access to any eBook for as long as you need it.

\section{Annual subscription packages}

We now offer special low-cost bulk subscriptions to packages of eBooks in certain subject areas. These are available to libraries or to individuals.

For more information please contact webmaster.ebooks@tandf.co.uk

We're continually developing the eBook concept, so keep up to date by visiting the website. 